\title{
BALANCING THE COMMONS IN SWITZERLAND
}

\section{INSTITUTIONAL TRANSFORMATIONS AND SUSTAINABLE INNOVATIONS}

Edited by Tobias Haller, Karina Liechti, Martin Stuber, François-Xavier Viallon and Rahel Wunderli 


\section{Balancing the Commons in Switzerland}

Balancing the Commons in Switzerland outlines continuity and change in the management of common-pool resources such as pastures and forests in Switzerland.

The book focuses on the differences and similarities between local institutions (rules and regulations) and forms of commoners' organisations (corporations of citizens and corporations) which have managed common property for several centuries and have shaped the cultural landscapes of Switzerland. At the core of the book are five case studies from the German, French and Italian speaking regions of Switzerland. Beginning in the Late Middle Ages and focusing on the transformative periods in the nineteenth and twentieth centuries, it traces the internal and external political, economic and societal changes and examines what impact these changes had on commoners. It goes beyond the work of Robert Netting and Elinor Ostrom, who discussed Swiss commons as a unique case of robustness, by analysing how local commoners reacted to, but also shaped, changes by adapting and transforming common property institutions. Thus, the volume highlights how institutional changes in the management of the commons at the local level are embedded in the public policies of the respective cantons, and the state, which generates a high heterogeneity and an actual laboratory situation. It shows the power relations and very different routes that local collective organisations and their members have followed in order to cope with the loss of value of the commons and the increased workload for maintaining common property management. Providing insightful case studies of commons management, this volume delivers theoretical contributions and lessons to be learned for the commons worldwide.

This book will be of great interest to students and scholars of the commons, natural resource management and agricultural development.

Tobias Haller is Professor in Social Anthropology and Managing Director of the Institute of Social Anthropology, University of Bern, Switzerland. He is the leading author of The Commons in a Glocal World (Routledge, 2019).

Karina Liechti is a Senior Research Scientist at the Centre for Development and Environment CDE and at the Institute of Social Anthropology, University of Bern, Switzerland. 
Martin Stuber is Senior Scientist at the Institute of History, University of Bern, Switzerland.

François-Xavier Viallon is a Political Scientist at the University of Lausanne, Switzerland.

Rahel Wunderli is a Postdoctoral Assistant at the Institute of History, University of Bern, Switzerland. 
$\fallingdotseq$ Taylor \& Francis Taylor \& Francis Group http://taylorandfrancis.com 
Earthscan Studies in Natural Resource Management

\section{Governing Renewable Natural Resources}

Theories and Frameworks

Edited by Fiona Nunan

Interdisciplinary Collaboration for Water Diplomacy

A Principled and Pragmatic Approach

Edited by Shafiqul Islam and Kevin M. Smith

\section{Peatlands}

Ecology, Conservation and Heritage

Ian D. Rotherham

\section{The Moroccan Argan Trade}

Producer Networks and Human Bio-Geographies

Daniel F. Robinson

Fair and Equitable Benefit-Sharing in Agriculture

Reinventing Agrarian Justice

Elsa Tsioumani

Participatory Governance of UNESCO Biosphere Reserves in

Canada and Israel

Resolving Natural Resource Conflicts

Natasha Donevska

\section{Balancing the Commons in Switzerland}

Institutional Transformations and Sustainable Innovations

Edited by Tobias Haller, Karina Liechti, Martin Stuber, François-Xavier Viallon and Rahel Wunderli

For more information on books in this series, please visit: www.routledge.com/books/series/ECNRM/ 


\section{Balancing the Commons in Switzerland}

Institutional Transformations and Sustainable Innovations

Edited by Tobias Haller, Karina Liechti, Martin Stuber, François-Xavier Viallon and Rahel Wunderli 
First published in English 2021

by Routledge

2 Park Square, Milton Park, Abingdon, Oxon OX14 4RN

and by Routledge

52 Vanderbilt Avenue, New York, NY 10017

Routledge is an imprint of the Taylor E Francis Group, an informa business

(C) 2021 selection and editorial matter, Tobias Haller, Karina Liechti,

Martin Stuber, François-Xavier Viallon and Rahel Wunderli; individual

chapters, the contributors

The right of Tobias Haller, Karina Liechti, Martin Stuber, François-Xavier Viallon and Rahel Wunderli to be identified as the authors of the editorial material, and of the authors for their individual chapters, has been asserted in accordance with sections 77 and 78 of the Copyright, Designs and Patents Act 1988.

This book is an output of a project funded by the Swiss National Science Foundation [grant CR11I1_166334] called SCALES (Sustainable Commons Adaptations to Landscape Ecosystems in Switzerland) (PI Prof. Dr. Tobias Haller, Institute of Social Anthropology, University of Bern, Switzerland)

All rights reserved. No part of this book may be reprinted or reproduced or utilised in any form or by any electronic, mechanical, or other means, now known or hereafter invented, including photocopying and recording, or in any information storage or retrieval system, without permission in writing from the publishers.

Trademark notice: Product or corporate names may be trademarks or registered trademarks, and are used only for identification and explanation without intent to infringe.

British Library Cataloguing-in-Publication Data

A catalogue record for this book is available from the British Library

Library of Congress Cataloging-in-Publication Data

Names: Haller, Tobias, editor.

Title: Balancing the commons in Switzerland: institutional transformations and sustainable innovations/edited by Tobias Haller [and four others].

Description: Abingdon, Oxon; New York, NY: Routledge, 2021. |

Series: Earthscan studies in natural resource management |

Includes bibliographical references and index.

Identifiers: LCCN 2020045648 (print) | LCCN 2020045649 (ebook)

Subjects: LCSH: Commons-Switzerland-Management.

Natural resources, Communal-Switzerland.

Classification: LCC HD1289.S9 B35 2021 (print) |

LCC HD1289.S9 (ebook) | DDC 333.2-dc23

LC record available at https://lccn.loc.gov/2020045648

LC ebook record available at https://lccn.loc.gov/2020045649

ISBN: 978-0-367-48873-4 (hbk)

ISBN: 978-1-003-04326-3 (ebk)

Typeset in Bembo

by Deanta Global Publishing Services, Chennai, India 


\section{Contents}

Prologue: Why Switzerland

1 Ostrom's legacy of robustness and the 'Swiss commons lab': Introductory reflections on change and power in commons studies

TOBIAS HALLER, JEAN-DAVID GERBER, KARINA LIECHTI, STÉPHANE NAHRATH, CHRISTIAN ROHR, MARTIN STUBER, FRANÇOIS-XAVIER VIALLON AND RAHEL WUNDERLI

\section{PART I}

Disciplinary approaches and theoretical reflections

2 Transformations of common pastures and woodlands in Switzerland: A historical perspective MARTIN STUBER AND RAHEL WUNDERLI

3 How do the commons meet the state?

A political science perspective

FRANÇOIS-XAVIER VIALLON AND STÉPHANE NAHRATH

4 Commons and peasant studies: Insights from social anthropology, human geography and agrarian economics

\section{PART II}

Case studies

5 Scopes and challenges of a huge corporation over time: The case of the Korporation Uri (Canton Uri) 
viii Contents

6 Urban commons in Alpine areas: The case of the Bürgergemeinde Chur (Canton Grisons)

MARTIN STUBER

7 Transformation, diversification, partnerships: The case of the Sarnen commoners' organisations (Canton Obwalden) 147 KARINA LIECHTI

8 Weak commons management, strong identity: The case of Val d'Anniviers (Canton Valais)

FRANÇOIS-XAVIER VIALLON

9 A fragile balance?: The case of pasture and forest management in Olivone (Canton Ticino)

MARK BERTOGLIATI

\section{PART III}

Synthesis

10 Transformation and diversity: Synthesis of the case studies TOBIAS HALLER, MARK BERTOGLIATI, KARINA LIECHTI, MARTIN STUBER, FRANÇOIS-XAVIER VIALLON AND RAHEL WUNDERLI 


\section{Prologue: Why Switzerland}

Balancing the Commons in Switzerland - the title of the present book refers to another book, published 40 years ago by the American anthropologist Robert McC. Netting: Balancing on an Alp: Ecological Change and Continuity in a Swiss Mountain Community (1981). It was a study of the mountain village of Törbel in the Swiss Canton of Valais from the Early Modern Period. Netting dealt with many topics of village life, among others the long-term history of communal property in alpine pastures and forests. Communal tenure proved to be a stable, sustainable way of using natural resources. In Törbel, it had been functioning for centuries without ending in the cul-de-sac predicted by the modern-day economic theory of the "Tragedy of the commons". This case of robust local cooperation, backed by solid historical documents, was selected as a prime example by the political scientist Elinor Ostrom to illustrate her counter-arguments in the Nobel Prize-winning book Governing the Commons: The Evolution of Institutions for Collective Action (1990). Since then the remote place in the Swiss Alps has become a positive symbol of international research into commons and the political hopes and concerns attached to them. The present book builds on this distinguished tradition and transcends it by giving a much fuller picture of the trajectories of common-pool resources in these mountain regions. It is an important, welcome contribution to the multidisciplinary discussion about sustainable development and to related discussions about biodiversity and cultural landscapes in a changing world.

In order to understand the starting point, let us briefly recall Netting's approach. He began his successful academic career with fieldwork in Nigeria. Inspired by new ecological currents of anthropology in the United States, he became interested in the relationship between population and resources in "traditional" societies. Thus he wanted to work with long demographic records and happened to find them in Valais, far from his first study region. At the core of his new research was the quantitative "balance" between villagers and their alpine environment, yet the first papers that he published about Törbel addressed aspects of land use and communal tenure. Netting was somewhat astonished at the fact that individual and communal land holding had gone hand in hand since the Middle Ages. He explained the dual tenure system with different land use: intense agricultural use in the individual case (on 
lower altitudes), extensive pastoral or forestal use in the communal case (on higher altitudes). He referred to Conditions of Agricultural Growth: The Economics of Agrarian Change under Population Pressure (1965), a much-discussed book by Ester Boserup, whom he also knew personally. There the developmental economist showed that the increasing frequency of cropping, driven by population growth in pre-industrial societies, was an important factor of change from general to specific rights of cultivation. In her model of land privatisation she also introduced a political factor determining whether the rights would go to the lord or to the peasants. Netting, however, considered only the economic argument and drafted a picture of long-term stability: communal tenure in Törbel, for him, was both very old and still functional in the present time.

When Netting and Ostrom met and then saw each other at Indiana University in Bloomington for a lengthy academic exchange in 1989, it was this picture that appealed to her in the first place. It appeared one year later in her Governing the Commons:

Although yields are relatively low, the land in Törbel has maintained its productivity for many centuries. Overgrazing has been prevented by tight controls. The common-pool resource not only has been protected but also has been enhanced by investments in weeding and manuring the summer grazing areas and by the construction and maintenance of roads.

Yet Ostrom was an experienced researcher of wide-ranging knowledge, and she added a cautionary note. This specific type of summer grazing was not the only one in the Swiss Alps where "considerable diversity of legal forms for governing alpine meadows" could be found. Besides additions, we also find selective reading in her summary of the village study. Its main question - longterm population history - was rendered only incidentally by Ostrom, and the chapter about family politics was not mentioned at all. Power struggles did not have a prominent, explicit position in her model.

Of course, it was largely by chance that Netting discovered Törbel for his second field study and that Ostrom took notice of the introductory chapters on land use and communal tenure in his 1981 book. Nonetheless, it is not completely accidental that a place in the Swiss Alps finds itself at the centre of the debate about commons. For different reasons, commons were, and still are, particularly prominent in the region. Mountain agriculture has a limited potential for agricultural intensification. Besides the steepness of the slopes, it is the short growing season in high altitudes that restricts land use. According to agronomists' estimates, annual grass production diminishes by about 40 per cent for every 1000 metres of elevation. In Törbel the stables of the main alp lie more than 2000 metres above sea level. When population increased rapidly in Switzerland and other European countries from the mid-eighteenth century onwards, common pastures were considered wasteful and were divided and used in an intensive way by individual farmers to increase production per unit 
land. It was an important movement - both on the level of "enlightened" political discourse and local practice - but few were so out of touch with reality to demand the division of the huge alpine pastures in lofty, rugged terrain. Within a few generations a specific geography came into being: large commons remained in the Alps, few commons in the surrounding lowlands. To be more specific, one should consider the settlement pattern as an additional factor. In regions with dispersed farmsteads, commons were rare from the outset. Many peasants had individual pastures and forests nearby. This applies to the Alps, too. In contrast to the Western and Central Alps (with Törbel), the Eastern Alps encompassed many dispersed settlements with relatively few commons.

The spatial setting of alpine agriculture and pastoralism provided a framework for the political organisation and power deployment at the communal and inter-communal levels. National politics entered this field above all in two moments: in 1798, Switzerland was occupied by troops of revolutionary France and for a while introduced its concept of municipalities led by equal male "citoyens". In 1874, a new national constitution allowed Swiss male citizens to vote and run for office in towns and villages other than their original ones. This opening of politics shook the ancient semi-democratic structures, based on local birth rights and privileges. It provoked a process leading to a so-called "communal dualism" in many, but not in all, places. The families with old birth and use rights separated from the political commune and constituted themselves under various denominations (Bürgergemeinde, Korporation, bourgeoisie, patriziato). They thereby reconfirmed the exclusion from the commons of families considered as local newcomers. This move included elements of "invention of tradition", since the privileges and obligations changed in the new context, and symbolic aspects grew more important. In the course of the nineteenth and twentieth centuries certain property items became very valuable, such as water rights for hydro-power and real estate in urbanised areas. Yet many mountain organisations remained inconspicuous or downright unattractive and changed only under the impact of certain external factors. In Törbel, for instance, the irrigation corporation, documented since the Late Middle Ages, was silently given up when a new technology was introduced around 1990.

Switzerland was a loose federal state, held together by alliances between Cantons and not by a monarchical dynasty and power centre. Nobody could homogenise the bewildering variety of communal and para-communal structures. But the grip of the nation over mountain territories grew stronger from the late nineteenth century onwards. To be sure, it varied according to resources, with forests more exposed to state intervention than pastures. One can roughly distinguish two periods. In the first period, the confederation acted in a resolute manner, forcing the periphery to assume new responsibilities. A prime example is the federal forest law for the mountainous part of Switzerland in 1876. It has been suggested that this method reflected international patterns of state-building during high colonialism and its far-ranging territorial claims. After World War II, with decolonisation on the agenda, the periphery became 
more self-assured. A new regionalism developed, and national subsidies for a variety of goals became standard. They were meant to preserve or promote certain structures but could not prevent massive changes, above all the drastic decrease of mountain farmers. In Valais, for instance, about 80 per cent of the population were active in agriculture in 1870. Today, less than 6 per cent work in that sector, and many of them in the low river plain where agriculture has been profoundly intensified. In mountain villages, often only a handful of farmers remained.

This change of occupational structure was a crucial factor for the polarisation of land use which accompanied the modernisation processes in alpine regions: dwindling use of difficult, little-rewarding terrain with intensified use of easy, more-rewarding terrain. An expressive indicator of the trend is the growth of woods. The so-called "forest transition", the change from net-deforestation to net-reforestation, is observable in many countries when the development of industrial and service activities reaches certain points. In Switzerland, forested surfaces grew by one fifth between 1880 and 2000, most of it in the mountains. In Valais, the increase was more than 25 per cent, in Ticino even 100 per cent. This huge change of the mountain landscape is linked to changes in relative prices for products and labour and attributable to many factors, on the very general level to new technologies and globalisation of markets which enlarged the differences between regions.

How is it possible to run mountain commons when few people are left, their bargaining power has diminished, and the products of forests and pastures have lost their former value? This is one of the principal questions of the present book. Fifty years ago, when Robert McC. Netting first visited Törbel, the significance of this question was much less obvious. The American anthropologist was surprised by documents revealing that regulations of pastures, forests and water courses were set up in the sixteenth century or earlier. And he could link this point in time with the practices he was able to observe during field work. So the governance of the commons appeared as a textbook example of sustainability, which made it somewhat superfluous to dig into the detailed history of managing alpine meadows and woods between the two points in time. Perhaps that history could have been more eventful and conflictive than we would presume from reading Balancing on an Alp. Today, under the said new conditions, it is timely to tackle detailed empirical work carefully and systematically. How robust or fragile were, and are, the commons organisations in the Swiss Alps in history and in the present day, and what can we presume about their future?

The authors of this book are all well-experienced in the scholarly debate on commons. They come from different disciplinary backgrounds. The historians bring in their skills of dealing with sources and putting themselves in the place of past actors and their decisions. The political scientists are trained in the systematisation of concepts on a less time-specific, general level. The anthropologists and human geographers have a transnational and transcontinental perspective on present problems. Indeed, Tobias Haller, the principal investigator, is an 
expert on commons in the Global South, and edited in 2019 the volume The Commons in a Glocal World: Global Connections and Local Responses. That volume was the outcome of an international conference in 2016. The conference then was a springboard for the collective research project titled: Sustainable Commons Adaptations to Landscape Ecosystems in Switzerland (SCALES): Institutional Change, Constitutional Innovations and Public Policies in Swiss Resource Management (supported by the Swiss National Science Foundation from 2017 to 2020). What you can read here are the results of that project.

Pooling together knowledge from different disciplines, the researchers have developed a coherent view on transformations and sustainable innovations in the Swiss "laboratory" of the commons. They follow similar methods in their regional case studies, with systematic oral interviews and analysis of historical documents. In the general sections, they discuss the pros and cons of different approaches and enlarge the scope of theoretical reasoning, mainly with new institutionalism and political ecology. Thus, in contrast to Netting and Ostrom, factors such as market, state and power become important issues. The volume is an appeal not so much to adhere to some sort of communal dualism as to promote civic engagement in finding satisfying solutions for people and alpine environments in times to come. The past has been challenging. The future might be so, too. 
$\fallingdotseq$ Taylor \& Francis Taylor \& Francis Group http://taylorandfrancis.com 


\title{
1 Ostrom's legacy of robustness and the 'Swiss commons lab'
}

\author{
Introductory reflections on change \\ and power in commons studies
}

\begin{abstract}
Tobias Haller, Jean-David Gerber, Karina Liechti, Stéphane Nahrath, Christian Rohr, Martin Stuber, François-Xavier Viallon and Rahel Wunderli
\end{abstract}

\subsection{Introducing this book}

Discussions on the commons have resulted in a very rich and sophisticated literature, originating with the work of Garrett Hardin (1968), through the reactions summarised and synthesised by Elinor Ostrom (1990) 30 years ago. This has ranged from local studies of resource management, broad comparative studies and topics such as collective action and experiments (Ostrom et al. 1994; Dietz et al. 2002; Poteete et al. 2010) to approaches involving the political ecology of the commons in a 'glocal' world (see, for a newer example, Haller et al. 2019). These research strands are also reflected in the International Association for the Study of the Commons (IASC), as well as in many publications in the International Journal of the Commons and other journals with related interests. The commons are also debated on several levels: from the local regulation of common-pool resources (CPRs) such as fisheries, pasture, forests and wildlife, to state, international and global levels such as those involving the sustainable development goals (SDGs). There is a focus on what can be called global commons, such as biodiversity and climate as issues related to collective ownership and governance on the global scale of a capitalist, neoliberal and sustainability-related state order. While some approaches see commons rather as patterns of 'commoning' (Bollier and Helferich 2015), which are to be understood as a collectively organised alternative to capitalism in practice, there are also views suggesting that 'commoning' hides that we are dealing with an individualised and a mostly challenging endeavour if power structures are not considered (see, for instance, Schläppi and Gruber 2018).

So, where is this book to be placed? It is based on the results of the interdisciplinary research project SCALES (Sustainable Commons Adaptations to Landscape Ecosystems in Switzerland), funded by the Swiss National Science Foundation (SNSF), and looks at the more 'classical' commons as regards continuity and change in the management of CPRs such as pastures and forests in Switzerland. The main focus of the project is the differences and similarities 
between local common-pool resource institutions (rules and regulations) and forms of commoners' organisations (corporations of citizens, corporations). We show that these organisations have been managing the common property of CPRs, especially alpine pastures and forests, for several centuries, and have shaped the cultural landscapes of Switzerland. The fact that this volume deals with comparative and historically grounded research in Switzerland, however, will be particularly interesting to an international audience for an important reason: a Swiss case study by the US social anthropologist Robert Netting in the Swiss Alps (Törbel) - published under the title Balancing on an Alp (1981) - had a major impact on the global debate around Elinor Ostrom's book Governing the Commons (1990). For that book, which celebrates its thirtieth anniversary in 2020, she received the Sveriges Riksbank Prize in Economic Sciences in Memory of Alfred Nobel. Balancing the Commons in Switzerland builds on Netting's work but traces the local histories of the commons in Switzerland back to the Late Middle Ages, and examines changes from that time to the present day. We thus closely examine the notion of robustness in Swiss commons and its challenges, in both a comparative and interdisciplinary way. Therefore, the book not only provides new insights into what has been seen as empirical proof that common property can be sustainable and that Swiss common property institutions show a high level of robustness; it also tries to unpack the power relations and diversity in the development of local commoners' organisations in a national context, in which common property rights are accepted by the Swiss civil code (and recognised in some cantonal legislations) (Knoepfel and Schweizer 2015) and state subsidies are provided in order to maintain the work undertaken by the commoners.

This unique situation, which we call the 'Swiss commons lab', will be of interest for all commons scholars in understanding this globally unique case and what it means for global studies of the commons. Our main hypothesis is that the robustness of Swiss commoners' organisations depends on their ability to balance between market (declines in the value of the CPRs and rising costs of maintenance) and the state (how to harness and adapt to state subsidies and policies). This balancing act depends on their bargaining power related to the state, the canton and the municipality, and the ability to be resilient to economic and social pressures. We also argue that members of commoners' organisations do not pursue a purely economic logic but try to maintain the overall common property.

External political, economic and institutional changes in the last 300 years, especially in the second half of the twentieth century, created important structural transformations that threaten the existence of the commoners. The growing complexity of policy interventions, overall loss of value for agricultural and forestry products and uncertainty about the interest of future generations as appointed successors have increased pressure on the management of CPRs, especially alpine pastures and forests, via common property. How did local commoners react to these changes by adapting and transforming common property institutions? This research question is not solely of interest to the 
Swiss, but also to international scholars in the field of commons studies and natural resource management.

The authors are an interdisciplinary group of researchers from human geography, history, political science and social anthropology, focusing on five alpine regions and their commoners' organisations in the German- (Uri, Grisons, Obwalden), French- (Valais) and Italian- (Ticino) speaking areas of Switzerland. They have gathered data regarding the robustness, change and innovations of commons institutions. The main focus is the local emic perception of common property, the perception of structural changes and how institutions have been reproduced, adapted and transformed.

The edited volume further highlights how institutional changes in the management of the agricultural and forestry commons at the local level are embedded in the public policies of the respective cantons (provinces) and the state. It shows the very different paths that local collective organisations and their members have followed in order to try to cope with the loss of value of the commons and the increased workload required for maintaining common property management. On the one hand, the authors argue that without public financial support from the state via subsidies, the communal management of the common property of pastures and forests would no longer be possible. This would also mean the loss of cultural landscape ecosystems in mountain areas that are key to providing for ecological and related services (biodiversity, protection against natural hazards, water maintenance, landscape quality and food security). On the other hand, the presented chapters suggest that subsidies

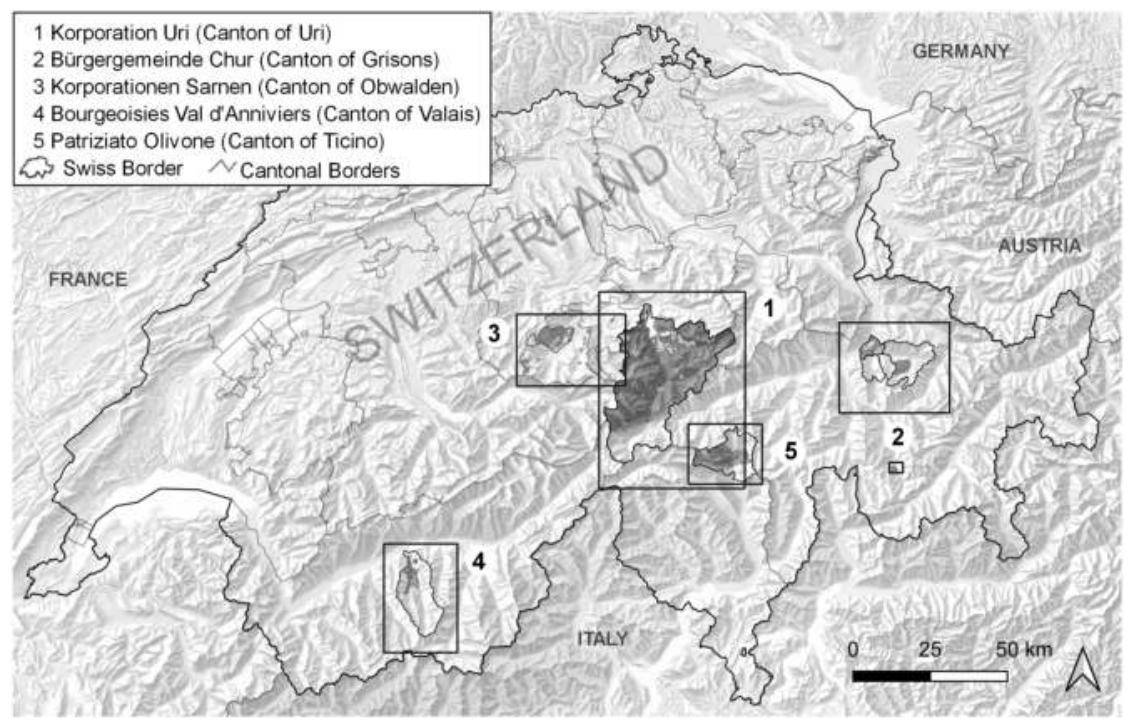

Figure 1.1 Overview: SCALES-Project Study Regions. Source: Map design and compilation by Sarah Baumgartner, University of Bern; hillshade: (C) swisstopo; geodata source: see maps of the project study regions. 
are not an easy fix, as commoners are still grappling with market pressure, generational gaps, high workload and the lowered bargaining power of CPR users within corporations and externally (on the level of municipalities, cantons and the state). This contributes to increasing the costs and decreasing the power of the commoners.

The case studies show how the various common property organisations cope differently with these challenges, and the way they are innovative or fragile, vulnerable or resilient to these changes. It also shows how different local contexts, even on a microscale, matter, and the diversity of the responses and adaptation strategies, as well as innovations. It becomes evident that an analysis also needs to refer to discussions about the work of Ostrom, and that although recognising its great merit - there is a need to critically contextualise her work and set it in a wider context, which is the underlying basis of this research.

\subsection{Ostrom, the 'Swiss commons lab' and critical theoretical reflections beyond}

In studies of the commons, we have been trapped in attempts to (over)simplify complex political, social, economic and ecological realities since the polemic text of Garrett Hardin (1968), and paradoxically also since the empirically and comparatively grounded work of Elinor Ostrom (1990). Hardin's view of environmental issues and population growth with its symbol of pasture being overused as a result of open access - which he mislabelled as the commons and its huge uptake, is a path-dependent legacy in the debate. Interestingly, the academic impact of the paper was not a discussion of 'unlimited' population growth, as intended by the author, but the sustainable use of CPRs. The key issue here is that both the problem statement and the remedies were based on simplistic modelling: one-size-fits-all arguments lead thousands of scholars and policymakers, as well as economists, to find legitimacy in relatively new forms of institutions for the governance of resources - state and private property. The widespread but unproved narrative of the overused common pasture and the simple solution to fix this simple problem did work well, despite any empirical evidence. The imagination on which it was based was so powerful that no one could escape its simplified structure, and it became the symbol of the mechanic truth of overexploitation.

Second, this legacy was - paradoxically - taken over by Ostrom, although she wanted to do the opposite, especially regarding the issue of simplistic views. Her take was to reject the panaceas implying either state or private property as solutions for all problems regarding the degradation of natural resources. Following the order of rational choice approaches (game theory), methodological individualism and frameworks of collective action, she needed to deal with the path-dependent request for simplicity. This binary thinking of simplicity vs. complexity and the listing of one, two, three or more solutions as a counter-argument to Hardin's oversimplifications did work to a certain extent. 
It gave the illusion of a large heterogeneous data set provided in an easily accessible form to create outcomes that were also simple. The Swiss case in particular was a convenient narrative (Netting's description of Törbel as a key model, see the prologue by Jon Mathieu in this volume) showing robustness, as if it were fallen from the sky of collective action. It offered the relief of proof - and no one would question the Swiss about their seriousness in institution building - that collective action can work and that this does - like an invisible hand - lead to good outcomes for all. Herein lies the legacy of the simplicity of Hardin's work for Ostrom: one of the major problems here is that history in this sense is presented like an instant vacuum: it just happened and is also frozen as the platform for the future. No one really deals with the debates regarding the power relations and negotiation processes leading to the development of common property institutions and the issue of "Who is in and who is out?" of common property. This inclusion-and-exclusion aspect shown by the empirical cases of CPR management, which Ostrom used to develop her design principles, resemble so-called 'club goods' with the mentioned exclusion rules for CPRs. Nevertheless, Ostrom's great achievement was to show that the collective ownership of resources can be sustainable, but it is the neglect of historically related power issues that is the pertinent failure, leading to the problematic legacy of simplicity.

We thus need to go not just beyond panaceas, but specifically beyond the panacea of collective action, and analyse what we have at hand regarding the asymmetric bargaining power of actors in a series of what Ostrom rightfully called action arenas (Ostrom 2005). But again, there are more variables affecting these action arenas than she proposed, including, for instance, the path-dependent developments of local and immigrating people in a specific topography, the power forces that shape commodification processes in a specific context, and the local and external actors, who again have different bargaining power. As our comparative research on Swiss commoners' organisations shows, it is the history of the emerging commons and conflicts that triggered the formation and adaptation of common property institutions, and not just collective actions. We argue that what is needed is a detailed historic ethnography of the commons in a specific context, and then, as a next step, a comparative approach that includes power relations within commoners' organisations and their power relationships with non-commoners, the market and the state. Questions need to be asked such as: did elites and market conditions exist before what we call the structural adjustments following industrialisation? How did they shape the structure of commoners' organisations? We also argue that the way Ostrom was trying to leave the simplicity legacy with her design principles, and also later on with the Institutional Analysis and Development (IAD) framework (Ostrom 2005), did not really help to further commons studies. It did not help us to understand the way local actors react to internal and external changes, and how this furthermore shaped the future of the governance of these resources. We need studies that tell the story of social interactions and negotiation processes in the sense of looking at power 
relations under conditions of change. This is important in order to understand the balancing act of governing the commons and who values what in which context, how this valuation needs to be negotiated (who has what power to do so) and how the subsequent selection process of institutions, their shaping and the production of legitimacy for the final choice, is determined, and by whom, and on which narratives and discourses it is based.

\subsection{Multi- and interdisciplinary approaches and methodologies}

The SCALES project on which this book is based was inspired by an interdisciplinary and multi-disciplinary approach to gathering data for the five case studies between 2017-2020. Historians helped to understand the past and path dependencies, which are still visible, using archive and literature research, and they developed a two-dimensional temporal structure from the Late Middle Ages to the present. Political scientists helped to explain the new actors, such as the state and other organisations, which provide a source of legal and institutional pluralism and influence the strategic action of actors and actor groups by analysing legal texts and conducting expert interviews. The economic and social logic of the commons explains the main tenure and distributional effects. This kind of study is then enhanced with the heterogeneity of local views and the way people act today in real life situations, insights provided by social anthropology, human geography and agro-economy with participant observations, open and structured interviews, focus group discussions and a common questionnaire (see below).

Going beyond Ostrom's legacy also meant not just discussing Ostrom's design principles in all cases but first understanding the diversity of the cases. On the one hand, trying to get the disciplines working separately provided a basis for the cases as shown above; but on the other hand, creating a dialogue between the disciplinary approaches was also necessary. One important common issue in this context was the study of power relations between actors in this field, which is why we adopted the strategy of examining different levels in order to move up and down the scales. This mostly helped to collect qualitative data on the actor's perspectives regarding their different bargaining power and the different challenges that the commoners' organisations have to balance between the market and the state. One theoretical framework allowing the integration of history and political science as well as environmental issues is the combined approach of New Institutionalism as outlined by anthropology (see Ensminger 1992; Haller 2013) and political ecology (see Robbins 2004). In this combined approach, historical, environmental, structural and political external factors have an impact on the valuation of resources and resource contexts. These then lead to the transformation of local power constellations of actors, their selection and the transformation of institutions, as well as forms of organisation and ideologies (narratives and discourses). The latter are chosen for the production of the legitimate selection of an institutional order (Haller 2019). 
In terms of research procedure, the team decided that each of the five case studies should be undertaken by one researcher, irrespective of their discipline. In order to control for a potentially strong disciplinary bias, the research team, in collaboration with the project leader, compiled a common thematic questionnaire that helped to gather comparable qualitative results relevant for all the disciplines in each case study. The interviews were conducted, among others, with representatives of the commoners' organisations, and included themes such as economy (issues of property production and distribution), politics (relationships with municipal, cantonal and state actors), common-pool governance (focusing on alpine pastures and forests), local forms of organisation, and issues of knowledge and identity. This provided comparable qualitative data regarding the kind of links that can be detected between communal ownership institutions embedded in history, public administration and power relationships, and exposure to economic pressure. These variables were then used to define a specific type of commoners' adaptation, institutional change and innovations for governing CPRs in the diverse cultural landscape ecosystems. The research team also gathered data on factors that contribute to conflict constellations, the loss of local bargaining power and resilience, as well as the increased vulnerability of the commoners' organisations in today's economic and political context.

In addition, the team collectively attended one- to two-day field trips to all the five case study areas that included meetings with representatives of commoners' organisations. Martin Stuber and Rahel Wunderli organised two conferences, where the results of SCALES were discussed with an international expert group: in Altdorf (2018) in cooperation with the Association internationale pour l'Histoire des Alpes, the Swiss Rural History Society and the Korporation Uri, in Bern (2019) in cooperation with the IASC.

Under the direction of Tobias Haller (University of Bern), Peter Finke (University of Zurich) and Stefan Mann (Agroscope, Zurich), several BA and $M A$ research projects in social anthropology were undertaken in connection to the SCALES project in order to gather more data based on participant observation of local perceptions regarding economic and institutional change, the development of innovations, and gender issues. In the field of history, under the supervision of Mathieu Leimgruber (University of Zurich), Christian Rohr (University of Bern), Martin Stuber (University of Bern) and Rahel Wunderli (University of Bern), several student qualification papers on our case studies were written. In the field of geography, one MSc research project was undertaken under the supervision of Stephan Rist (University of Bern) and Karina Liechti (University of Bern).

A final comment in this section is related to the issue of diversity. Local terms and meanings used by local groups varied substantially, and so the English term 'commoners' organisation' was used in order to make the very different cases in three language areas comparable. The local names of the respective organisations (such as Bürgergemeinde or Korporation in German, bourgeoisie in French and patriziato in Italian) are set in italics in the chapters, with further explanations on their sub-categories and local specificities. 


\subsection{Overview of the book}

After this introduction, the book continues with an outline of the three different disciplinary approaches and theories. In Chapter 2, entitled 'Transformations of common pastures and woodlands in Switzerland: a historical perspective', Martin Stuber and Rahel Wunderli illustrate the way local resources in the 'agrarian society' were contested, how the pressure of modernisation in the 'industrial society' unfolded, and the polarised utilisation of the commons in the 'age of ecology'. They outline the development of the Swiss commons landscape in four phases (formation in the Late Middle Ages; consolidation in the Early Modern Period; transformation in the nineteenth century; adopting new roles in the twentieth century). Chapter 3 on 'How do the commons meet the state? a political science perspective' by François-Xavier Viallon and Stéphane Nahrath contributes to the debate on the interactions between commoners' organisations and the state. The authors describe three modes of interaction between commoners' organisations and the state. These modes may allow the strengthening of commoners' organisations, and/or the reinforcement of the coherence of state intervention. They argue that analysing these interactions is crucial to our understanding of why and how commoners' organisations emerge, perpetuate, and collapse in complex legal settings increasingly shaped by public policies. Finally, in Chapter 4, 'Commons and peasant studies: insights from social anthropology, human geography and agrarian economics', Tobias Haller, Karina Liechti and Stefan Mann discuss socio-cultural, economic and space-related systems and take an interdisciplinary social science perspective on the institutional change of the commons. They offer a broad overview of relevant approaches related to Swiss rural societies and commons studies in anthropology, human geography and agro-economics. They explain the role that New Institutionalism plays in the analysis, outline the work of Netting and Ostrom, and subsequently focus on institutional change and the role of bargaining power and ideology elaborated by Jean Ensminger (and revised by Tobias Haller), as well as the way power can be analysed from political ecology perspectives. They conclude by outlining the relevance of non-economic and identity utility for the maintenance of the commons, and reflect on resilience, vulnerability and bottom-up institution building (constitutionality) in the 'Swiss commons lab'.

These theoretical reflections have affected the structure of the five case studies that we have selected from the three Swiss language regions, and that reflect different structural and institutional constellations, such as a strong commoners' organisation within a cantonal system (Korporation Uri, canton Uri), an urban commoners' organisation in the alpine area (Bürgergemeinde Chur, canton Grisons) and the four diverse Sarnen Korporationen (canton Obwalden). This is followed by the cases from the French-speaking area, the bourgeoisies and consortages of Val d'Anniviers (canton Valais) and the Italian-speaking patriziato in Olivone (canton Ticino) (see Figure 1.1). 
In the first of the five case studies (Chapter 5), Rahel Wunderli outlines the history of the Korporation Uri, under the title 'Scopes and challenges of a huge corporation over time: the case of the Korporation Uri (Canton Uri)'. The Korporation Uri is one of the biggest common pool organisations in Switzerland, with property covering about 70 per cent of the canton of Uri. The basis of this specific organisation lies in the Early Middle Ages, when the Landleute von Uri started to organise themselves on a regional scale in order to regulate transport routes and the cooperative use of pastures and forests. Later on, this union grew into a political entity and was able to take over legislative and juridical competences from foreign and resident lordships. Until the nineteenth century, the Allmendgenossenschaft was identical to the state. In the course of the nation-building process, the two elements were separated, and in 1888 the Corporation was withdrawn from the state authorities. Since then, the organisation has met the challenges required to keep its position within the canton, to expand its economic base, to adapt the use of its forests and pastures to changing contexts, and to adjust to issues such as women's civic rights and modern state requirements. Today, the Corporation finds itself in a condition of financial strength, with a lively organisational structure, but also several issues, among them the growing number of citizens that are not involved in agriculture and make different demands towards the organisation.

In Chapter 6, 'Urban commons in Alpine areas: the case of the Bürgergemeinde Chur (Canton Grisons)', Martin Stuber shows how the community of Chur developed in the Late Middle Ages when it was emancipated from the bishop and constituted itself as a guilds city. In the Ackerbürgerstadt (agrarian city) the extensive forest was not only used for the supply of wood, but also for cattle and pasture farming. A cross-border system of transhumance developed from the sixteenth century onwards, with Chur acquiring extensive alps at Arosa. Only citizens were entitled to make full use of the common property, and the increasing number of Hintersassen (socmen) only had limited access. In 1840 the Guilds Constitution was dissolved, and in 1875 municipal dualism was created to include a Bürgergemeinde (Corporation of Citizens) and a Politische Gemeinde (municipality of residents). The property of collective forests and pastures was given to the Bürgergemeinde, while the use of collective forests and pastures was attributed to the Politische Gemeinde. The focus was no longer on securing a sustainable supply of natural products but on creating the maximum sustainable yield (financial return) for the municipality's finances. With the change in relative prices from the 1950 s onwards and state contributions, economic conditions changed fundamentally once again.

In Chapter 7, 'Transformation, diversification, partnerships: the case of the Sarnen commoners' organisations (Canton Obwalden)', Karina Liechti discusses transformational change in four different commoners' organisations. She shows that these commoners' organisations have not only adapted to a changing societal, political and economic environment but have transformed themselves in order to remain important players in the local context. She points out that due to the diverse structures of the four corporations, they are more or 
less resilient or vulnerable to change. Transformation processes, for example, require, among other things, the reproduction and adaptation of ideology in order to reproduce legitimacy. Legitimisation pressures differ between corporations that have significantly changed their economic base on the one hand, and those whose main economic base comprises 'traditional' resources on the other. By acting collectively and by positioning themselves as reliable partners, the Sarnen corporations are providing locally adapted and grounded means of dealing with contemporary ecological and societal challenges.

In Chapter 8, 'Weak commons management, strong identity: the case of Val d'Anniviers (Canton Valais)', François-Xavier Viallon traces the historic transformations of commoners' organisations back to the thirteenth century, when bourgeoisies and consortages were central actors of local political and economic life. The chapter shows how commoners' organisations progressively lost their legal competencies and transformed into village-based organisations contributing to the preservation of local heritage, and allowing local and outside members to bind to their familial origins. Looking at the recent changes in the state of common pool resources, this chapter identifies a set of current strategies adopted by bourgeoisies and consortages to manage their resources, which mainly comprise a civic hall, forests, pastures, and vineyards. In the case of forests, commoners carry out market-based activities to secure income and maintain resource use. The creation of a cantonal forest association representing the interests of commoners strengthens their role as intermediaries in the policy implementation process. Further, there is a strong tendency for the use of pastures to be privatised, coupled to the preservation of symbolic management structures. Despite strong public support, agricultural activities in the valley continue to diminish, and put the preservation of the landscape ecosystem at risk.

Finally, in Chapter 9, 'Fragile balance: the case of pasture and forest management in Olivone (Canton Ticino)', Mark Bertogliati outlines the current properties of the Patriziato Generale of Olivone, Campo, Largario (PG-OCL), which cover some 8,500 hectares and, after Airolo, comprise the biggest corporation of the canton Ticino in territorial terms. During the Middle Ages this alpine community passed through a crucial stage characterised by expanding control over forest, pastures and roads, intertwined with Italian urban development. Collective resource management and internal organisation evolved in a structured and dynamic system consisting of different institutional levels (village corporations, degagne, vicinanza). This "multi-layered community" was the result of different local needs, negotiations with other communities and 'empowering interactions' with state authorities. From the second half of the nineteenth century institutional, demographic, economic and socio-ecological changes on a broader scale required new approaches, and complex arrangements of traditional uses of forests and mountain pastoralism. The subsequent long process of transformation on the path to modernity highlights the adaptability of this community, but also its fragile balance in the management of resources and internal decision-making processes. There are several issues of vulnerability and low resilience, such as subsidy systems that do not match local 
needs, price changes for milk and cheese, and a decline in the bargaining power of commons users in the patriziato, as well as the fragility of its members and the issue of central actors of very high age managing the commons.

In the synthesis (Chapter 10), the research team presents a comparative summary dealing with the wide variety of case studies. They propose several key theses for comparison that are also relevant for the international debate:

A) It is not just collective action but elites and markets that have shaped the historical commons. Managing local cultural landscape ecosystems was a political and space-specific process based on common property institutions that have shown robustness and economic resilience despite high resource-specific and political pressure since the nineteenth century.

B) Commoners' organisations faced important challenges during the energy change from wood-based fuels to fossil fuels, and the societal structural change in the industrialisation era. This process has led to a reduction in the economic value of CPRs, and has thus reduced the bargaining power of commoners' organisations, albeit in different ways.

C) Differences in the bargaining power of commoners' organisations can be explained by their size and political power, the different types of resources they own, the use they make of available resources, and the skills they use to engage in new activities and balance themselves against the market.

D) Commoners' organisations try to adapt to the decline in market value of natural resources by internally cross-subsidising the maintenance of alpine farming and forestry through new activities such as housing or hydropower.

E) Commoners' organisations are situated in a field of tension between new responsibilities and regulations (e.g. nature protection) and the persistence of traditional structures.

F) Commoners' organisations need to balance their relationships with state actors and subsidies policies: their relationship with state actors is shaped by the state acknowledging the important role of alpine pasture and forest use and management, as well as the maintenance of landscape services; however, while state support is what makes the sustainable use of commons possible, it does not cover all costs and is not always shaped in a participatory way.

G) In order to mitigate such challenges and to find locally adapted solutions in a kind of 'Swiss commons lab' based on guaranteed property rights and subsidies, locally adapted strategies are made possible from bottom-up. The range of these local institutional innovations, as well as their success, depends on the way they can be locally developed, incorporating all local actors in a participatory way. Such participatory processes lower the vulnerability and strengthen the resilience of commoners' organisations.

$\mathrm{H})$ Participatory and transformation processes depend on the external view of the commoners' organisations and the way it is shaped. The narrative that commoners receive a large amount of subsidies and related legitimacy 


\section{Tobias Haller et al.}

issues is counteracted by the local commoners' narrative that there is a great deal of unpaid work involved in resource use and landscape maintenance. This is guaranteed based on the strong positive 'identity utility' of the commoners. By this we mean that, as opposed to a pure economic utility, identity utility also accounts for a positive identity value of a form of alpine agrarian lifestyle in this context. This also includes a strong social structure and cohesion in the commoners' organisations.

I) Advantages of commoners' systems include their long-term perspective due to a focus on maintaining resources rather than purely generating profit in order to keep the resource base for future generations of commoners. Their relatively fast reactivity/responsiveness due to straightforward small structures and organisational freedom, and their acting as a brake on changes that are too fast and too fundamental, are also assets.

J) When positioning themselves as reliable partners in both maintaining ecosystem and landscape services, and in societal matters, commoners' organisations can contribute to sustainable development by maintaining a dynamic diversity of structures and providing locally adapted and grounded means of dealing with today's ecological and societal challenges.

K) Due to the large areas of land they sustainably manage (60 to $90 \%$ of pastures and forests in the study areas) and their local knowledge, commoners' organisations could play a vital role in the implementation of Sustainable Development Goals (SDGs) in Switzerland.

These theses show, on the one hand, that there are differences between the Swiss commons and many other commons systems on a global scale. But on the other hand, Swiss commons also demonstrate that given the freedom to self-organise, and if there is the ability to level economic pressures, new vital forms of commons governance are possible. Commoners' organisations in Switzerland differ in their power constellations, however, and we argue that this can make them more or less resilient and vulnerable. This also means that an important lesson to be learned from the Swiss cases for the global debate is that only guaranteeing common property, despite it being an important precondition, will not solve all the challenges to commoners crafting their institutions. They have to position themselves in a state- and market-specific context; and they have to fight to retain their own way of governing and to reach a locally acceptable level of redistributing the costs and benefits.

\section{References}

Bollier, D., and Helferich, S. (eds.) (2015) Patterns of Commoning. Amherst: Commons Strategies Group.

Dietz, T., Dolsak, N., Ostrom, E., and Stern, P. C. (eds.) (2002) The Drama of the Commons. New York: National Academies Press.

Ensminger, J. (1992) Making a Market: The Institutional Transformation of an African Society. Cambridge: Cambridge University Press. 
Haller, T. (2013) The Contested Floodplain: Institutional Change of the Commons in the Kafue Flats, Zambia. Lanham: Lexington Books.

Haller, T. (2019) 'Towards a new institutional political ecology: How to marry external effects, institutional change and the role of power and ideology in commons studies', in Haller, T., Breu, T., de Moor, T., Rohr, C., and Znoj, H. (eds.), The Commons in a Glocal World: Global Connections and Local Responses (pp. 90-120). London: Routledge.

Haller, T., Breu, T., de Moor, T., Rohr, C., and Znoj, H. (eds.) (2019) The Commons in a Glocal World: Global Connections and Local Responses. London: Routledge.

Hardin, G. (1968) 'The tragedy of the commons', Science, vol. 162, no 3859, pp. 1243-1248.

Knoepfel, P., and Schweizer, R. (2015) 'Le local et le global: quatre défis de la codification du droit foncier dans le cadre du processus de rédaction du Code civil suisse de 1907', in Travési, C., and Ponsonnet, M. (eds.), Les conceptions de la propriété foncière à l'épreuve des revendications autochtones: possession, propriété et leurs avatars (pp. 79-93). Marseille: PacificCredo Publications.

Netting, R. (1981) Balancing on an Alp: Ecological Change and Continuity in a Swiss Mountain Community. Cambridge: Cambridge University Press.

Ostrom, E. (1990) Governing the Commons. The Evolution of Institutions for Collective Action. Cambridge: Cambridge University Press.

Ostrom, E. (2005) Understanding Institutional Diversity. Princeton: Princeton University Press.

Ostrom, E., Gardner, R., and Walker, J. (1994) Rules, Games, and Common-pool Resources. Ann Arbor: University of Michigan Press.

Poteete, A. R., Janssen, M. A., and Ostrom, E. (2010) Working Together: Collective Action, the Commons, and Multiple Methods in Practice. Princeton: Princeton University Press.

Robbins, P. (2004) Political Ecology: A Critical Introduction. Malden: Blackwell.

Schläppi, D. and Gruber, M. C. (eds.) (2018) Von der Allmende zur Share Economy: Gemeinbesitz und kollektive Ressourcen in historischer und rechtlicher Perspektive. Berlin: BWV Verlag. 
$\fallingdotseq$ Taylor \& Francis Taylor \& Francis Group http://taylorandfrancis.com 
Part I

Disciplinary approaches and theoretical reflections 
$\fallingdotseq$ Taylor \& Francis Taylor \& Francis Group http://taylorandfrancis.com 


\title{
2 Transformations of common pastures and woodlands in Switzerland: A historical perspective
}

\author{
Martin Stuber and Rahel Wunderli
}

The diversity of the Swiss commons landscape and the current importance of collectively regulated Alpine pastures and forests in Switzerland can only be understood historically. In this chapter we look for historiographical points of departure and propose a two-dimensional temporal structure from a longterm perspective, which we carry out using the general Swiss development (Sections 2.2 and 2.3) and which will then be refined in the regional case studies (Chapters 5 to 9).

\subsection{Historiographical starting points}

Municipal dualism is one of the essential particularities of Switzerland. In many places there is not only a Politische Gemeinde (municipality of residents), but also a Corporation of Citizens. There are different names for the latter, in different cantons, such as Bürgergemeinde in the Cantons of Basel, Grisons, Solothurn and Zug; Burgergemeinde in Oberwallis and Bern; Orts(bürger)gemeinde in Aargau, St. Gallen, Thurgau and Uri; bourgeoisie or commune bourgeoise in Freiburg and Unterwallis; as well as patriziato in Ticino. There are no Corporations of Citizens in Geneva, Neuenburg, Waadt, Zurich, Nidwalden or Schwyz, although in the latter two cantons there are Korporationsgemeinden (corporation municipalities). Other examples of cantons which still have corporations under public law are Appenzell, Glarus, Obwalden, Uri and Zug.

These Corporations of Citizens and other corporations under public law as Genossame, Teilsame, or consortage, being successors to the former commons, own local lands, woodland and real estate. Their sociological core elements are the ancient families who were already politically and economically privileged during the ancien régime. Their maintenance and renewal is based on inheritance and marriage, and on applying for and purchasing the status. Although the number of new members through birth and marriage cannot be affected, the Corporations of Citizens and other corporations under public law are provided with a means of control through the right to grant (corporation) citizenship (i.e. membership) (Head-König 2003, Sieber 2005, Head-König 2015, Stalder/Stuber 2015, Head-König 2019). 
It is not only their names, but also their degrees of organisation, their rights and activities, which distinguish these corporations from each other. In its commemorative publication for its fiftieth anniversary, the Swiss Association of Corporations of Citizens and other corporations wrote that in all of Switzerland there were some 2,000 corporations under public law. The Association states that these corporations are not subject to federal law, but exclusively to canton law, which is so different from canton to canton 'that not one canton could be found where there are just ten corporations of citizens, corporations or patriciates which are identical with each other' (Göpfert 1994: 15).

The only author, for the time being, who has made the attempt to provide a comprehensive overview of this variety of legal forms for all of Switzerland is August von Miaskowski. In his classical work Die Schweizer Allmend in ihrer geschichtlichen Entwicklung (1879) he compares Switzerland to a 'laboratory and a research ward for social policy' where, in some cantons, 'a wide share, indeed the biggest share of productive soil is still collective property, as in our time it is otherwise only to be found in Russia'. Miaskowski bases his comparative study on a spatially differentiated list of questions in order to obtain a view of the subtle differences of the commons law, which he believes to be crucial when it comes to social-political effects. For example, he asks for each region, 'that non-citizen residents are also provided with full or at least quoted shares of the utilisation of commons', 'that utilisation is distributed in kind or also in money', and 'that those commons plots are distributed long-term or shortterm or lifelong or even hereditarily' (Miaskowski 1879: VII, XIII).

This Switzerland-wide comparative research design is still inspiring today, although it was not then adopted by historical research. Whereas there were older traditions of researching common property in Alpine regions in France and Italy, in German-speaking countries the research of collective property focused on the distribution of commons in the course of the transition to modernity for a long time (see Suter 1998). Accordingly, these studies mostly dealt with lowlands where the transfer from collective to private property was marked. Common property, which existed on a large scale, mostly in mountainous regions, was clearly less the focus of historical research and was mostly limited to local studies giving an insider's view of the institutions concerned.

Dealing with common property in the Alpine region was newly stimulated by Elinor Ostrom's Governing the Commons (Ostrom 1990), which indeed basically rested on Swiss examples, that is on the Valais community of Törbel (Netting 1981). The growing international interest in Swiss commons served as a stimulation for once again examining the whole variety of the phenomenon, beyond the classical example of Törbel. Referring to Ostrom's classical work and her further developments, a number of analyses were presented, mostly addressing the collective utilisation of resources in the twentieth century (Gerber et al. 2008, Baur and Binder 2013, Tiefenbach 2013, Landolt and Haller 2015, Landolt 2019), but also from a longue durée perspective beyond this time frame (Schläppi 2007, Stalder/Stuber 2015, Schläppi 2018, Schläppi 2019). 
We also make use of Elinor Ostrom's conceptional considerations as analysis tools for the comparative analysis of the landscape of Swiss commons in our case studies, that is the eight design principles which, according to Ostrom, support the robustness of collectively cultivated local resources. These famous principles are supposed to serve less as a fixed research programme for our case studies, however, and more as a source of multiple inspiration. The clear distinction between legitimate users and those who are not entitled to benefit from the resources of the corporation, which is given as a condition (Principle 1), raises an awareness of the exclusion or inclusion of groups. The criterion of regulations being adjusted to local conditions (Principle 2) directs our attention to the natural-spatial compatibility of utilisation. The postulated common decision-making regarding utilisation regulations (Principle 3) leads to questions about the forms of participation. That those actors entrusted with supervising the resource are themselves users or accountable to users (Principle 4) prompts an analysis of the division of labour and communication within the organisation. The intended appropriateness of sanctions (Principle 5) supports a differentiated analysis of the enforcement of levelled sanctions. The demand for mechanisms of conflict-solving that work directly (Principle 6) sharpens our view of the changing cultural, political and legal ways of conflict-solving. The need for a minimum degree of state recognition for collective utilisation rights (Principle 7) directs our attention to the interactions between commoner organisations and superior state authorities. The idea of several levels of interwoven governance structures (Principle 8) motivates a precise reconstruction of local constellations.

\subsection{The institutional development of the Swiss 'landscape of commons'}

We suggest a structuring of the long-term perspective on the history of the corporations into four phases: their formation in the Late Middle Ages (ca. 1250-1500), consolidation in the Early Modern Period (ca. 1500-1800), transformation in the nineteenth century, and the adoption of new roles in the twentieth century.

\section{Formation in the Late Middle Ages}

With the help of historical documents most of the commons organisations that still exist in Switzerland can be traced back to the Late Middle Ages. Although the early organisations are different from the current forms concerning their tasks and their social influence, this long history provides them with a reputation, especially in the context of the current sustainability debate.

From 1250 to 1500, in the region of today's Switzerland - as elsewhere in Europe - numerous associations of persons arose, which independently regulated the exploitation of their environments as well as of areas outside their immediate territories. They were diverse types of organisations: neighbourhoods, villages, valley communities, cities, brotherhoods, parishes, guilds and 
cooperatives. Their common property might be an alp or the woods, pastures and waters around a settlement; it could be buildings, roads, weirs (watercourses, flood protection devices); or other kinds of infrastructure. Often their sphere of action was limited to the local; however, some operated cross-territorially - such as the cooperatives of teamsters which were active in transport (Steiner 2013, Burmeister 2015, Stadler 2015).

Many of these organisations appeared in documents at this time by way of regulations where they declared their claims to territories, competences or power. The intention of these organisations to structure both their space as well as the people living there, and to work in a stabilising way, becomes obvious from these written sources. The competence of sanctioning violations of rules was thus crucial for their profile. Parallel to their attempts at securing peace, court files document the many conflicts with which they were confronted - both internally and with other corporations or superior authorities (worldly and clerical feudal lords).

Delimitation from the outside was the raison d'etre of the associations. Population pressure was comparably low, but the supply of resources in an 'agrarian society' was far from being stable and could immediately become precarious. The exclusion of outsiders was thus a matter of self-protection; however, it went in cycles, for at the same time workforce, financial means and social networks of incomers were welcome goods. There are regions where the circle of those entitled to use local resources was not definitively legally fixed far into the Early Modern Period. Not only family relations or the length of habitation but also the socio-economic position could open up prospects for participation (Carlen 1988, Blickle 1990, Roth 2018).

The diversity of today's commons organisations in Switzerland is a product of its medieval origins, in so far as these organisations developed in the context of the variety of political structures in those days. According to the regional centres of power, the corporations enjoyed different degrees of autonomy and were able to become more or less politically weighty. The villages west of the Saane river - then in the sphere of influence of Savoy and today's French-speaking parts of Switzerland - tended to be less autonomous than the places east of the Saane. It is also typical of the 'commons landscape' that the mountainous regions were less subject to manorialism than the lower areas (Mittelland), which supported the establishment of local self-administration. The main factors in this respect are that these regions were less profitable for the manorial system. Accordingly, the rulers' political-economic emphasis was elsewhere - the Habsburgs' emphasis, for example, as the most influential dynasty in the territory of today's Switzerland, was on the rising cities in the Mittelland (Sablonier 2008, Steiner 2013).

The establishment of community self-administration should not be interpreted as an anti-feudal act, but at least in the beginning it was closely connected to manorialism. Land development in the Late Middle Ages, that is the development and clearing of new settlement and agricultural areas, was supported by the landlords; for example, by offering extended self-administration 
rights (colonists' rights). Later, commons organisations purchased land and utilisation rights from noble families and clerical landlords. Not least, the administrative staff of the feudal system, acting as the local representatives of the landlords, often played a leading role in establishing local comoners' organisations (Sablonier 2008).

\section{Consolidation in the Early Modern Period}

Three fundamental changes in communities and corporations with collectively owned property at the political-legal level can be seen in the Early Modern Period (ca. 1500-1800). First, there is evidence for the transfer of commons into private property from the fifteenth century on, mainly in the hill country. In the sixteenth and seventeenth centuries this development increased in the form of partial distributions and reached parts of the lowlands as well. In the eighteenth century the Economic Enlightenment spoke out vehemently in favour of distributing the common lands in the lowlands which, however, was not realised until the course of the nineteenth century (Leonhard and Mattmüller 2001). As a result of these developments, today we find collectively owned property mainly in the Alpine regions and the Alpine foreland.

Second, the significance of the local communities became stronger. In 1551 the Eidgenössische Tagsatzung (Swiss Meeting of Representatives) had decided that each community had to take care of its own poor. To protect from the claims of too many applicants, it was necessary to define, by way of granting Heimatrecht (citizenship), who was a member of the respective community and who was not. From then on, the citizenry consisted of those who might claim to be entitled to poor welfare; and the Hintersassen (socmen), on the other hand, who were excluded from poor welfare at their places of residence. The policy of granting citizenship and social policy thus had to be adjusted to each other. In the course of a lengthy process, community poor welfare started pushing through in the different Cantons of Switzerland, such as in the Canton of Bern, with the Beggars' Statutes of 1664. The goal was support for the poor at the place where their needs were well known, while, on the other hand, limiting their mobility and keeping them where they could be more easily controlled. This policy only gradually pushed through in Switzerland, at first in the cities, and then also in the rural areas (Head and Schnegg 1989, Flückiger 2002).

Third, given the population growth as well as the growing pressure on food supplies and opportunities for making a living in agriculture, crafts, trades, government and administration, as well as the problems of welfare policy, these communities and corporations became increasingly socially exclusive. Newcomers were prevented from claiming citizenship and were only granted the status of Hintersassen (socmen), with very limited utilisation rights. Since the sixteenth and seventeenth centuries the local citizenries had increasingly attempted to limit entitlements to the ancient families and shaped their 
citizenship and utilisation policies accordingly. Poor welfare, common land and the most important political positions were supposed to be protected against too many aspirants. Furthermore, full citizens started to become further differentiated themselves. Finally, in many places only a small minority of entitled families - the village aristocracy or the urban patriciate - could participate in political decision-making (de Capitani 2001, Holenstein 2014, Head-König 2015, Stadler 2015).

\section{Transformation in the nineteenth century}

The invasion by the French and the Helvetic Revolution of 1798 marked the end of old Switzerland. Despite the postulated principles of liberty and brotherhood, however, the Helvetik created a municipal code based on the inequality of the ancien régime. By way of a dual municipal organisation, with a municipality of residents and a Corporation of Citizens, it exclusively attributed the common lands and the other assets of the community such as treasure, real estate and the Armengut (property for the poor) to the latter. Historian Daniel Schläppi interprets this process as a pragmatic compromise: 'In terms of revolution, it was easier to behead a king [...] than to remove property which was firmly rooted within the population or to shatter local corporative utilisation systems and cycles of collective resources.' The locals used their considerable political weight to reserve the corporation goods exclusively for themselves. The newly established canton authorities also wanted to root the Corporations of Citizens and other corporations within the new law, so that they would continue taking over public tasks, thus relieving the state (Leonhard and Mattmüller 2001, Stadler-Planzer and Stadler 2008: 437, Schläppi 2011: 65).

In the decades to follow there were many changes back and forth in many cantons. In the periods of the Mediation (1803-1813) and Restoration (18131830) the municipalities of residents were abandoned again and political rights were limited to full citizens or full members of corporations. Only with the liberal turnaround of the Regeneration (1831-1846) did the resident principle push through once again, which in most cases resulted in definitively installing municipal dualism. Various cantons developed differently, however. Equal rights for Swiss resident citizens concerning all municipality matters were only stipulated by the Federal Constitution of 1874 (Sieber 2005, Ladner 2013, Holenstein 2014).

\section{Adopting new roles in the twentieth century}

The commons organisations in Switzerland in the twentieth and twenty-first centuries still vary greatly in their organisation and fields of activity. Many of their former tasks have been taken over by the now dominant political organisations of the Federation, canton and municipality (of residents), while at the same time the local scope for action has been reduced by nationwide state laws. 
Some of the associations of persons originating from the Late Middle Ages (e.g. neighbourhoods, brotherhoods, specific cooperatives) have sunk into insignificance and been dissolved. Landed property is crucial to the survival of the remaining commons organisations.

Most of those corporations still influential today are organisations under public law. Cooperatives under private law, such as Alpine cooperatives, tend to own smaller areas, and their field of activities is limited to specific actions. The political weight of the organisations under public law becomes obvious, by the Swiss Association of Corporations of Citizens and other corporations (SVBK) which was founded in 1945, and today (2018) consists of 13 cantonal associations and 62 individual members (Schneider 2019).

Apart from the structuring of today's commons organisations into those under public law and those under private law, Swiss social anthropologist Arnold Niederer has suggested another categorisation (Niederer 1991). He developed three types of the broad range of organisations based on the different ways of utilising their landed property:

a) Agricultural collectives for which the utilisation of commons and commonly owned woodlands still has a real function

b) Urban Corporations of Citizens of the patrician kind, whose activities are mostly oriented towards the common good and towards culture

c) Corporations of Citizens and other corporations making use of their landed property for commercial purposes.

This classification cannot be understood disjunctively. Many corporations by their nature combine two or more of these basic types at the same time, and in the course of history they may transfer from one type to the other.

Despite a centuries-long shrinking process, which in some regions started as early as in the fifteenth century, commons are thus still of considerable size in certain mountainous regions. It is no coincidence that, when it came to determining the SCALES case studies, for which vitality, social relevance and landed property were crucial criteria, it was examples from mountainous cantons that were selected. It must be noted, however, that there are also still strong corporations in the Mittelland, among them the Burgergemeinden of the cities of Bern, Basel and Fribourg, or - as a comparably well-known rural example - the Korporation Pfäffikon. There, as in the case of many rural corporations in the Mittelland, the tasks mostly involve the granting of citizenship and the administration of buildings such as hospitals, former orphanages, and so on. Furthermore, most Corporations of Citizens and other corporations both in the Mittelland and the mountain regions are also owners of woodlands, which is why the Association of Swiss Woodland Owners is one of the most important partner organisations in the SVBK. Alpine pastures, which are common in the mountainous regions, are less significant for the SVBK (Göpfert 1994, Stadler-Planzer and Stadler 2008, Stalder and Stuber 2015). 
In the twentieth century several trends forced the commons organisations under public law to adjust their political-social positioning. The spatial mobility of the population clearly increased in the second half of the century, as a result of which the social and legal relevance of a person's place of origin has become less significant. Poor welfare has been delegated to the municipalities of residents. The proportion of people working in agriculture has drastically declined, which is of great significance when it comes to maintaining the natural resources. Not least, the woodlands and Alpine pastures administered by people working in agriculture have continually lost financial value since the mid-century.

Three main strategies can be identified as a reaction to these challenges. The first involves continuing with those activities which are still possible, which requires a high degree of adaptability given the many changes to the management of assets in the course of economic development (e.g. the modernisation of forestry and agriculture). Second, there have been conversions, or at least shifts of emphasis, in the administration of assets. Buildings on alps which are no longer used for agriculture are, for example, converted into mountain restaurants; former city pastures are converted into building land and built on; or waters owned by a corporation are used for power generation. Third, new fields of activity are explored - mostly in the field of culture (sponsoring, education) - in the context of which a wider circle than just the members of the respective corporation often benefits from the money invested. The 'invention of tradition', which has already been addressed in the Prologue, is also part of this strategy.

Finally, the improved legal position of women since the 1970s (suffrage, matrimonial law), initiated by the state, has also arrived at the commons organisations. Those that are under public law have, since 1991, been forced to grant active and passive franchise to their female members. The matrimonial law of 1985 means that members marrying a non-member no longer lose their utilisation rights. In legal terms, male dominance over the organisation has thus come to an end; in practice, however, even 30 years after setting the course in this direction, only a few positions are occupied by women (Sieber 2005, Stalder and Stuber 2015, Head-König 2019, Stuber and Baumgartner 2019, Schaffner 2007).

\subsection{The long-term economy of woodlands and pastures}

The considerable landed property of the Corporations of Citizens and other corporations is a common feature which is still of great significance today. Corporations of Citizens own 33 per cent of all Swiss woodlands, 8 per cent are owned by other corporations, and another 23 per cent are owned by municipalities (Brändli et al. 2020: 267). And even 58 per cent of the Swiss summering areas are owned by corporations under public law (Baur et al. 2007: 255). We will now examine Alpine pastures and woodlands from an all-Switzerland long-term perspective. For this purpose we suggest a framework based on the use of energy (Pfister 2014), already used for research into the history of the 
commons of the Burgergemeinde Bern (Stuber 2018, Stuber and Baumgartner 2020): the 'agrarian society' which was mostly based on local solar energy until the mid-nineteenth century, the 'industrial society' based on the import of coal, which had become possible after having been connected to the railroad network (from the mid-nineteenth century to the mid-twentieth century) and the 'consumption society' with mass consumption and mass motorisation based on the availability of oil (since the mid-twentieth century).

\section{Contested local resources in the 'agrarian society'}

The sun provided the key energy in the 'agrarian society'. Food for humans and animals was produced on the basis of photosynthesis, and wood was the main energy resource. Given comparably limited transportation, the local supply situation was crucial, and local resources were thus contested. The longterm maintenance of a dynamic balance of population and crop yields was achieved through cultural strategies (impediments to marriage, emigration) in combination with control over collective resources (Pfister 2014).

\section{Pastures}

Many pastures in the territory of today's Switzerland are the result of human clearing activities, for since the end of the last glacial period, natural grasslands have only existed above the tree line and along rivers, where periodical floods kept areas open. The reduction of woodlands peaked in the course of the Landesausbau (land development) in the Middle Ages. Trading relationships were important for this, as was population growth. The share of cattle was increased at the expense of sheep and goats, resulting in a growing need for pasture. This development generated a number of conflicts and made regulation necessary. In areas where feudalism was strong - in particular in the Mittelland - the pastures were part of the Zelgensystem (tillable land system), and their extension and cultivation were closely connected to agriculture and fallow lands. In the mountainous regions the pastures were not subject to any fixed rotation system. Here, the regulations determined at least the beginning and end of Alpine grazing, as well as the number of animals to be grazed. Certain kinds of animals were often assigned to individual pastures (Mathieu 1992, Mathieu et al. 2016, Head-König 2013, Stadler 2013).

Pastures existed both as commons and as the property of individual households. Privately owned areas tended to be used for hay, whereas the commons were reserved for grazing; however, there are examples of overlap: commons being mowed in summer, and private areas open to all grazing animals at certain times (Gemeinweide) (Leonhard 2009, Dubler 2004).

To increase the productivity of pastures, they were changed into meadows reserved for the production of hay, watered and fertilised with marl and aglime, or else nitrogen-absorbing legumes were grown as food crops. From the eighteenth century on, both the establishing sciences and the peasant population 
were involved in such developments. Most of these measures were applied to the particularly fertile areas with Mittelland and Alpine foothills as preferred regions. How far individual pastures in the mountain regions were also subject to intensification is unknown. Alps statistics from the late nineteenth century at least allow for the conclusion that collective pastures were hardly intensified. As a matter of fact, intensification pushes were followed in most cases by changing common lands into private property. Remote and wide Alpine pastures in high regions which were greatly affected by ecological dynamics (rock fall, avalanches, floods) were not preferred areas for such developments (Strüby 1914, Ineichen 1996, Inniger 2006, Stuber et al. 2009).

\section{Woodlands}

The multifunctional supply forest of the 'agrarian society' primarily had to satisfy the needs of the local population. On the one hand, it provided firewood, construction timber and timber for the production of tools and fences. On the other hand, it served as a source of food, directly as a supplier of berries, herbs and wild fruits, indirectly as pasture for livestock, as a place for fodder and litter or as a temporary agricultural area. Regionally highly diverse rights of ownership and use can be assumed for Switzerland before 1800, which could overlap in one and the same forest. At the level of forms of ownership, a somewhat simplified distinction can be made between dominion forests, private forests and forests of communities or corporations. The latter formed the most extensive category in terms of area. They were part of the commons, the use of which was usually determined relatively autonomously by the communities and corporations.

The eighteenth century saw the development of scientifically based forestry throughout Europe, which placed sustainable timber management at its centre. Its legitimation was the diagnosed shortage of wood, which from today's point of view can be seen as a tangle of actual supply obligations, emerging growth perspectives and the interests of the authorities. The loose and light forest forms that had emerged from the many different forms of agricultural use were interpreted by the emerging professional forestry as a sign of poor economy. The forests of the Alps and Prealps also played an important role in the supply of energy and raw materials for large commercial enterprises (salt works, iron smelting, brickworks), and for towns in a wider area, provided that the conditions for timber transport on the larger rivers were favourable. The push for deregulation in the wake of the fall of the ancien régime after 1800 led to extensive deforestation and timber exports, especially in the mountain regions (Grossmann 1972, Radkau 1986, Stuber 2008, Stuber and Bürgi 2012, Schuler 2013, Irniger 2015, Stuber 2020).

\section{Modernisation pressure in the 'industrial society'}

The transformation from 'agrarian society' to 'industrial society', which involved much more than just the development of industrial sites, began in 
Great Britain as early as the eighteenth century, before spreading all over Europe with a delay of about 100 years. A cluster of technological innovations (iron smelting by the help of coke, steam engine, mass mining of coal) meant that the limitations on the growth of the 'agrarian society' were eradicated. Based on an efficient network of global traffic, the growing 'industrial society' could for the first time reach back to almost unlimited resources of fossil energy. In Switzerland, this transition took place from the mid-nineteenth century on, having been connected to the European railway network which made coal available as an energy resource that was independent of the area. This transformation process was only partial, however, for biomass was not replaced by coal in many fields. In particular, agriculture and forestry still depended on land, and were thus in a precarious co-existence with the growing industrial sector and under increasing pressure to modernise. The answers to this were, on the one hand, the development of an 'agrarian-industrial knowledge society' and, on the other hand, the beginning of a national agricultural, forest and environmental policy (Moser 2012, Pfister 2014, Auderset and Moser 2018).

\section{Pastures}

When the 'industrial society' was establishing in Switzerland, it had much in common with the production of 'agrarian society', and a large share of the population was still working in agriculture. Soon, however, the differences between agrarian and industrial production became a topic of discussion and 'rationalisation' a key concept of agronomics and of establishing agricultural policy. For example, a movement developed for the improvement of alps, propagating a more intensified cultivation of Alpine pastures. Better use should be made of the 'national capital' which seemed to lie dormant in these wide, badly used areas. Behind this there was concern about mountain farming, which, as a result of the transportation revolution, started falling behind agriculture in the Mittelland. It was losing its centuries-old predominance in cattle breeding when, in the lower regions, arable farming was abandoned in many places as a result of cheap grain imports, in favour of pastoral farming and the production of cheese (Auderset and Moser 2018, Strüby 1914).

Whereas the first engine-driven machines appeared in the lowlands at the beginning of the twentieth century, along with new kinds of fertilisers and new methods for processing of grass, the traditional ways of cultivation were still predominant in the mountainous regions. The alps improvement movement denounced collective property as an obstacle, however, because a large share of the mountain farms could benefit from subsidies by way of the collectively owned Alpine pastures, the Federation considered Alpine farming a starting point for its agrarian-political measures and started funding meliorations and the modernisation of infrastructural facilities (roads, stables, huts) in the Alpine regions (Baumann 2011, Viallon et al. 2019, Schweizerisches LandwirtschaftsDepartement 1914). 
Woodlands

The Swiss Federal Forestry Police Act (1876) subjected the forests of the Alps and the Prealps to a professional and sustainable utilisation regime. The historical context meant that flood prevention appeared to be the main objective of the Forestry Police Act. The repeated major floods between 1834 and 1868, which were interpreted as a consequence of deforestation in the mountain forests, legitimised restrictions to the freedom of forest owners in the Alpine regions - mostly commoner organisations - in order to protect the owners in the lowlands. Economic motives also played a major role. In order to meet the growing needs of the emerging 'industrial society', the maximum sustainable yield was sought in timber production.

Depending on perspective, the first federal forestry law was either criticised by historians as a 'paternalistic attitude of politicians towards the local population' or evaluated positively because it represented 'an important starting point for forestry and forestry policy development for many mountain regions'. Recent research relativises the dichotomy between the irresponsible mountain population on the one hand and the emerging state forest policy, which was supported by a professional group of experts, on the other hand. Instead, more attention is given to interdependence processes in which the commoners organisations played an important role in the sustainable regulation of Alpine forests. This was also in the commoners' own interest, as the financial return from timber production was often their main source of income until the mid-twentieth century (Bloetzer 1978, Bertogliati 2014, Viallon et al. 2019, Stuber 2020).

\section{The polarisation of utilisation in the 'consumption society'}

In the mid-1950s a new kind of growth dynamic was unleashed, transforming the 'industrial society' into the 'consumption society' and resulting in an unprecedented rise in the material standard of living. This burst of growth was based on the utilisation of new energy sources (oil, gas, nuclear energy) and was accompanied by the development of new technology complexes. The crucial cause was a long-term decrease in the relative price for oil, resulting in gigantic growth in energy consumption, mass consumption and mass mobility. Agriculture and forestry also became subject to the growth logics of industrial production. Tractors replaced horses, machines replaced handwork, and the soil was flooded with large amounts of fertilisers, weed killers and pesticides, resulting in impressive increases in output but also in ecologic problems. A polarisation of use can be observed: the simultaneous overexploitation of favourable areas and abandonment of peripheral areas which could not be cultivated with the help of machinery. The unintended consequences of modernisation are just one element of many ecologic effects which have dominated the social and political discourse since the 1960s. In complementary terms, we may as well speak of the 'ecologic era' (Pfister 2014, Radkau 2014). 
The structural changes to which agriculture became subject in the course of the twentieth century and which resulted in rapid and fundamental change after mid-century led to a massive decline in the number of farms and the workforce, revolutionised the ways of cultivation and markedly changed crops and livestock in a very short span of time.

Today, the plant population on mechanically cultivated pastures is usually based on specifically assorted seed mixtures which are appropriately fertilised and, if necessary, treated with chemicals. This high degree of intensification is accompanied by the loss of large pasture areas in favour of settlements and traffic facilities in the Mittelland, and in many low zones of the mountain region.

It took longer until the degree of motorisation was markedly increased in mountain farming, because the uneven terrain required the development of special machinery. Mechanisation progressed, however, and the polarisation of utilisation is a common phenomenon even in Alpine farming. Many former Alpine pastures are no longer used and have become overgrown, and roads for the transport of animals and the mobility of staff have become an important factor in the future of an alp. As the growing season is shorter in higher regions, investments in the mechanisation of pasture cultivation are a comparably high financial burden for Alpine farms. A double trend can be identified in agrarian policy in recent decades. Competitiveness and mechanisation have been supported, and as a reaction to environmental damage caused by intensified production, ecologic compensatory measures have also been supported. This double strategy is also true for policies concerning Alpine farming. The latter is supposed to meet the standard of 'rationally run farms'. At the same time the 'difficult production conditions' of Alpine farming are recognised, and there are attempts to balance them with appropriate financial measures. There was a marked shift in the setting of political actors when the Federation, under the impression of declining numbers of cattle driven to alps, increased the summering subventions around the turn of the millennium and connected them to regulations for cultivation. This placed local regulations under pressure (Baumann and Moser 1999, Moser 2015, Werthemann and Imboden 1982, Wunderli 2016, Lauber et al. 2013).

\section{Woodlands}

The transformation to a 'consumption society', which began in the 1950s, and the accompanying fall in energy prices, once again fundamentally changed the framework conditions for forestry. On the one hand, higher yields of pastures, improved transport connections and alternative sources of income made agricultural forest use obsolete. On the other hand, a gap began to open between stagnating timber revenues and rising labour costs, which made the forestry sector deficient in many ways. In contrast, the ecological value of the forest gained in importance, as did its function as a place for leisure and 
recreation. This multifunctional use, which integrates not only timber use but also ecosystem services and recreational values, reveals the historical sequence of three periods of use in the longue durée: a 'period of traditional multiple use', a 'period of primary timber production' and a 'period of modern multi-impact management'.

Modern multifunctionality was largely implemented through the Federal Law on Forests (1991). On the one hand, it can be seen as a response to the precarious economic situation of forestry in the 'consumption society'. On the other hand, it contains a whole series of postulates that had shaped public discourse with the ecological turnaround since the 1970s. Perhaps the most interesting innovation is the introduction of subsidies for the provision and maintenance of forest reserves to preserve the diversity of fauna and flora. In the long term, forest owners can completely renounce the use of the forest in favour of the ecological protection of the forest, and be compensated by the federal government and the cantons for the loss of income (Bürgi 1999, Bisang 2001, Stuber and Bürgi 2012, Schuler 2015).

\section{References}

Auderset, J., and Moser, P. 2018. Die Agrarfrage in der Industriegesellschaft. Wissenskulturen, Machtverhältnisse und natürliche Ressourcen in der agrarisch-industriellen Wissensgesellschaft (1850-1950). Wien u.a.: Böhlau.

Baumann, W. 2011. Agrarrevolution. In Historisches Lexikon der Schweiz HLS. https://hls -dhs-dss.ch/de/articles/013827/2011-03-23/.

Baumann, W., and Moser, P. 1999. Bauern im Industriestaat. Agrarpolitische Konzeptionen und bäuerliche Bewegungen in der Schweiz 1918-1968. Zürich: Orell Füssli.

Baur, I., and Binder, C. 2013. Adapting to socioeconomic developments by changing rules in the governance of common property pastures in the Swiss Alps. Ecology and Society 18/4: 60 .

Baur, P., Müller, P., and Herzog, F. 2007. Alpweiden im Wandel. Agrarforschung 14/6: 254-259.

Bertogliati, M. 2014. Dai boschi protetti alle foreste di protezione. Comunità locali e risorse forestali nella Svizzera italiana (1700-1950). Bellinzona: Edizioni Casagrande.

Bisang, K. 2001. Historische Entwicklung der institutionellen Regime des Waldes zwischen 1870 und 2000. In Knöpfel, P., Kissling-Näf, I., and Varone, F. (eds), Institutionelle Regime für natürliche Ressourcen: Boden, Wasser und Wald im Vergleich. Basel u.a.: Helbling and Lichtenhahn, pp. 141-182.

Blickle, P. 1990. Friede und Verfassung. Voraussetzungen und Folgen der Eidgenossenschaft von 1291. In Historischer Verein der Fünf Orte (ed.), Innerschweiz und frühe Eidgenossenschaft. Olten: Walter-Verlag, pp. 15-204.

Bloetzer, G. 1978. Die Oberaufsicht über die Forstpolizei nach Schweizerischem Bundesstaatsrecht. Zürich: Schulthess Polygraphischer Verlag.

Brändli, U.-B., Abegg, M., and Allgaier-Leuch, B. 2020. Schweizerisches Landesforstinventar. Ergebnisse der vierten Erhebung 2009-2017. Birmensdorf: Eidgenössische Forschungsanstalt für Wald, Schnee und Landschaft WSL/Bundesamt für Umwelt BAFU. 
Bürgi, M. 1999. A case study of forest change in the Swiss lowlands. Landscape Ecology 14/6: $567-576$.

Burmeister, K.H. 2015. Nachbarschaft. In Historisches Lexikon der Schweiz HLS. https://hls -dhs-dss.ch/de/articles/016403/2015-06-19/.

de Capitani, F. 2001. Aristokratisierung. In Historisches Lexikon der Schweiz HLS. https://hls -dhs-dss.ch/de/articles/016377/2001-09-17/.

Carlen, L. 1988. Die Bürgergemeinde in der Schweiz. Gestern - heute - morgen. Freiburg: Universitätsverlag.

Dubler, A. 2004. Trattrecht. https://hls-dhs-dss.ch/de/articles/027591/2004-09-01/.

Flückiger, E. 2002. Zwischen Wohlfahrt und Staatsökonomie. Armenfürsorge auf der bernischen Landschaft im 18. Jahrhundert. Zürich: Chronos.

Gerber, J.-D., Nahrath, S., Reynard, E., and Thomi, L. 2008. The role of common pool resource institutions in the implementation of Swiss natural resource management policy. International Journal of the Commons 2/2: 222-247.

Göpfert, R. 1994. Festschrift zur 50. Generalversammlung des Schweizerischen Verbandes der Bürgergemeinden und Korporationen 1945-1994. Bern: Schweizerischer Verband der Bürgergemeinden und Korporationen.

Grossmann, H. 1972. Flösserei und Holzhandel aus den Schweizer Bergen bis zum Ende des 19. Jahrhunderts. Zürich: Schweizerisches Landesmuseum.

Head, A.-L., and Schnegg, B. (eds). 1989. Armut in der Schweiz (17.-20. Jh.). Zürich: Chronos.

Head-König, A.-L. 2003. Les biens communaux en Suisse aux XVIIIe et XIXe siècles: enjeux et controvers. In M.-D. Demélas and N. Vivier (eds), Les propriétés collectives face aux attaques libérales (1750-1914). Europe occidentale et Amérique latine. Rennes: Presses Universitaires, pp. 98-118.

Head-König, A.L. 2013. Weiden. In Historisches Lexikon der Schweiz HLS. https://hls-dhs -dss.ch/de/articles/027648/2013-09-26/.

Head-König, A.-L. 2015. Common land and collective property in pre-Alpine ad Alpine Switzerland. Tensions regarding access to resources and their allocation (Middle Agestwentieth century). In Grüne, N., Hübner, J., and Siegl, G., (eds), Ländliche Gemeingüter / Rural Commons. Kollektive Ressourcennutzung in der europäischen Agrarwirtschaft / Collective Use of Resources in the European Agrarian Economy, Jahrbuch für Geschichte des ländlichen Raumes. Innsbruck, Wien, Bozen: Studienverlag, pp. 232-243.

Head-König, A.-L. 2019. The commons in highland and lowland Switzerland over time. Transformation in their organisation and survival strategies (seventeenth to twentieth century). In Haller, T., Breu, T., de Moor, T., Rohr, C., and Znoj, H. (eds), The Commons in a Glocal Worlds. Global Connections and Local Responses. London: Routeledge, pp.156-172.

Holenstein, A. 2014. Hintersassen. In Historisches Lexikon der Schweiz HLS. https://hls-dhs -dss.ch/de/articles/015998/2014-12-05/.

Ineichen, A. 1996. Innovative Bauern. Einhegungen, Bewässerung und Waldteilungen im Kanton Luzern im 16. und 17. Jahrhundert. Luzern: Rex-Verlag.

Irniger, M. 2006. Futtermittel. In Historisches Lexikon der Schweiz HLS. https://hls-dhs-dss. ch/de/articles/013861/2006-11-20/.

Irniger, M. 2015. Wald. Mittelalter und Frühe Neuzeit. In Historisches Lexikon der Schweiz HLS. hls-dhs-dss.ch/textes/d/D7849.php?topdf=1.

Ladner, A. 2013. Gemeinde. 19. und 20. Jahrhundert. In Historisches Lexikon der Schweiz HLS. https://hls-dhs-dss.ch/de/articles/010261/2013-04-05/. 
Landolt, G. 2019. Swiss alpine pastures as common property: a success story of bottom-up institution-building in Sumvitg, Canton of Grisons, Switzerland. In Haller, T., Breu, T., de Moor, T., Rohr, C., and Znoj, H. (eds), Commons in a "Glocal" World. Global Connections and Local Responses. London: Routledge, pp. 233-254.

Landolt, G., and Haller, T. 2015. Alpine common property institutions under change. Conditions for successful and unsuccessful collective action by Alpine farmers in the Canton of Grisons, Switzerland. Human Organization 74/1: 100-111.

Lauber, S., et al. (eds). 2013. Zukunft der Schweizer Alpwirtschaft. Fakten, Analysen und Denkanstösse aus dem Forschungsprogramm AlpFUTUR. Birmensdorf, Zürich-Reckenholz: Eidg. Forschungsanstalt für Wald, Schnee und Landschaft WSL, Forschungsanstalt Agroscope Reckenholz-Tänikon ART.

Leonhard, M. 2009. Nutzungsrechte. In Historisches Lexikon der Schweiz HLS. https://hls -dhs-dss.ch/textes/d/D25978.php?topdf=1.

Leonhard, M., and Mattmüller, M. 2001. Allmend. In Historisches Lexikon der Schweiz HLS. https://hls-dhs-dss.ch/de/articles/013704/2001-05-17/.

Mathieu, J. 1992. Eine Agrargeschichte der inneren Alpen. Graubünden, Tessin, Wallis 15001800. Zürich: Chronos.

Mathieu, J., Backhaus, N., Hürlimann, K., and Bürgi, M. (eds). 2016. Geschichte der Landschaft in der Schweiz. Von der Eiszeit bis zur Gegenwart. Zürich: Orell Füssli.

von Miaskowski, A. 1879. Die Schweizerische Allmend in ihrer geschichtlichen Entwicklung vom XIII. Jahrhundert bis zur Gegenwart. Leipzig: Duncker and Humblot.

Moser, P. 2012. Die Agrarproduktion. Ernährungssicherug als Service public. In Halbeisen, P., Müller, M., and Veyrassat, B. (eds), Wirtschaftsgeschichte der Schweiz im 20. Jahrhundert. Basel: Schwabe, pp. 568-630.

Moser, P. 2015. Viehwirtschaft. 19. und 20. Jahrhundert. In Historisches Lexikon der Schweiz HLS. https://hls-dhs-dss.ch/de/articles/026236/2015-04-01/.

Netting, R.M. 1981. Balancing on an Alp. Ecological Change and Continuity in a Swiss Mountain Community. Cambridge: Cambridge University Press.

Niederer, A. 1991. Gemeindedualismus - ein schweizerisches Unikum. In Niederer, A. (ed.), Alpine Alltagskultur zwischen Beharrung und Wandel. Ausgewählte Arbeiten aus den Jahren 1956 bis 1991. Bern, Stuttgart, Wien: Haupt, pp. 314-331.

Ostrom, E. 1990. Governing the Commons. Cambridge: Cambridge University Press.

Pfister, C. 2014. Umweltnutzung und -probleme. In Historisches Lexikon der Schweiz HLS. hls-dhs-dss.ch/de/articles/024598/2014-01-14/.

Radkau, J. 1986. Zur angeblichen Energiekrise des 18. Jahrhunderts. Revisionistische Betrachtungen über die "Holznot". Vierteljahresschrift für Sozial und Wirtschaftsgeschichte 73/1: 1-37.

Radkau, J. 2014. The Age of Ecology: A Global History. Cambridge: Polity Press.

Roth, P. 2018. Korporativ denken, genossenschaftlich organisieren, feudal handeln. Die Gemeinden und ihre Praktiken im Bergell des 14.-16. Jahrhunderts. Zürich: Chronos.

Sablonier, R. 2008. Gründungszeit ohne Eidgenossen. Politik und Gesellschaft in der Innerschweiz um 1300. Baden: hier + jetzt.

Schaffner, M. 2007. Die Korporation Ursern zwischen Beharren und Fortschritt. Vorläufige Bilanz eines Forschungsprojekts. Histoire des Alpes - Storia delle Alpi-Geschichte der Alpen 12: 101-114.

Schläppi, D. 2007. Das Staatswesen als kollektives Gut. Gemeinbesitz als Grundlage der politischen Kultur in der frühneuzeitlichen Eidgenossenschaft. In Mar, J., and Frings, A. (eds), Neue politische Ökonomie in der Geschichte. Köln: Franz Steiner Verlag, pp. 169-202. 
Schläppi, D. 2011. Grenzen der Gleichheit. Wie und warum die helvetischen Regenten vor dem Gemeinbesitz von Korporationen kapitulierten. In Würgler, A. (ed.), Grenzen des Zumutbaren. Erfahrungen mit der französischen und der Helvetischen Republik (1798-1803). Basel: Schwab, pp. 47-65.

Schläppi, D. 2018. Einleitung. In Schläppi, D., and Gruber, M.-C. (eds), Von der Allmende zur Share Economy. Gemeinbesitz und kollektive Ressourcen in historischer und rechtlicher Perspektive. Berlin: Berliner Wissenschaftsverlag, pp. 9-70.

Schläppi, D. 2019. Konzeptionelle Überlegungen zu einem universellen Paradigma anhand der Commons in der frühneuzeitlichen Schweiz. In Head-König, A.-L., Lorenzetti, L., Stuber, M., and Wunderli, R. (eds), Kollektive Weiden und Wälder. Ökonomie, Partizipation, Nachhaltigkeit (Histoire des Alpes / Storia delle Alpi / Geschichte der Alpen, Bd. 24), Zürich: Chronos, pp. 215-235.

Schneider, S. 2019. 75 Jahre Schweizerischer Verband der Bürgergemeinden und Korporationen, Bern: Schweizerischer Verband der Bürgergemeinden und Korporationen.

Schuler, A. 2013. Alpen. Waldnutzung. In Historisches Lexikon der Schweiz HLS. https://hls -dhs-dss.ch/de/articles/008569/2013-07-17/\#HWaldnutzung.

Schuler, A. 2015. Wald. 19. und 20. Jahrhundert. In Historisches Lexikon der Schweiz HLS. hls-dhs-dss.ch/textes/d/D7849.php?topdf $=1$.

Schweizerisches Landwirtschafts-Departement. 1914. Das Bodenverbesserungswesen der Schweiz. Bern: Wyss.

Sieber, B. 2005. Bürgergemeinde. In Historisches Lexikon der Schweiz HLS. https://hls-dhs -dss.ch/de/articles/026443/2005-02-16/.

Stadler, H. 2013. Alpen. Landwirtschaft in der Frühen Neuzeit. In Historisches Lexikon der Schweiz HLS. https://hls-dhs-dss.ch/de/articles/008569/2013-07-17/\#HWirtschaft sgeschichte.

Stadler, H. 2015. Genossenschaft. In Historisches Lexikon der Schweiz HLS. https://hls-dhs -dss.ch/de/articles/008970/2015-02-17/.

Stadler-Planzer, H., and Stadler, P. 2008. Die Korporation Pfäffikon SZ. Grundlagen, Entstehung, Entfaltung. Pfäfikon: Verlag der Korporation.

Stalder, B., and Stuber, M. 2015. Die Burgergemeinde Bern im schweizerischen Kontext. In Von Bernern und Burgern. Tradition und Neuerfindung einer Burgergemeinde, Bd. II. Baden: hier+jetzt, pp. $779-830$.

Steiner, P. 2013. Gemeinde. Mittelalter und Frühe Neuzeit. In Historisches Lexikon der Schweiz HLS. https://hls-dhs-dss.ch/de/articles/010261/2013-04-05/.

Strüby, A. 1914. Die Alp- und Weidewirtschaft in der Schweiz. Solothurn: Lüthy in Komm.

Stuber, M. 2008. Wälder für Generationen. Konzeptionen der Nachhaltigkeit im Kanton Bern (1750-1880). Umwelthistorische Forschungen, Bd. 3, Köln u.a.: Böhlau.

Stuber, M. 2018. Kollektive Ressourcen und Nachhaltigkeit in der Longue durée. Die burgerlichen Wälder der Stadt Bern vom Ancien Régime bis in die Gegenwart. In Schläppi, D., and Gruber, M.-C. (eds), Von der Allmende zur Share Economy. Gemeinbesitz und kollektive Ressourcen in historischer und rechtlicher Perspektive. Berlin: Berliner Wissenschaftsverlag, pp. 173-188.

Stuber, M. 2020. Vom Versorgungswald zum Försterwald - die 'Oberaufsicht über die Forstpolizei' in der Longue durée. In Mieg, H.A., and Haefeli, U. (eds), Umweltpolitik in der Schweiz. Von der Forstpolizei zur Ökobilanzierung. Basel: NZZ Libro, pp. 34-53.

Stuber, M., and Baumgartner, S. 2019. From natural supply to financial yields. The common fields of the Bernese Civic Corporation since the seventeenth century. In Haller, T., 


\section{Martin Stuber \& Rahel Wunderli}

Breu, T., de Moor, T., Rohr, C., and Znoj, H. (eds), The Commons in a Glocal Worlds. Global Connections and Local Responses. London: Routeledge, pp. 173-191.

Stuber, M., and Bürgi, M. 2012. Hüeterbueb und Heitisträhl. Traditionelle Formen der Waldnutzung in der Schweiz 1800-2000. Bern, Stuttgart, Wien: Haupt (2. Aufl.).

Stuber, M., Moser, P., Gerber-Visser, G., and Pfister, C. (eds). 2009. Kartoffeln, Klee und kluge Köpfe. Die Oekonomische und Gemeinnützige Gesellschaft des Kantons Bern OGG (1759-2009). Bern, Stuttgart, Wien: Haupt.

Suter, A. 1998. Neue Forschungen und Perspektiven zur Geschichte der ländlichen Gesellschaft in der Schweiz (1500-1800). In Trossbach, W., and Zimmermann, C. (eds), Agrargeschichte. Positionen und Perspektiven. Stuttgart: Lucius and Lucius, pp. 73-91.

Tiefenbach, M. 2013. Alpkorporationen - traditionelle Institutionen nachhaltiger Landschaftsentwicklung: das Beispiel der Bergschaften Grindelwalds im Kontext aktueller gesellschaftlicher Herausforderungen. Grindelwald: Sutter.

Viallon, X.-F. Liechti, K., Stuber, M., and Wunderli, R. 2019. Vermittlung, Einbau, Komplementarität - Formen des staatlichen Zugriffs auf kollektive Weiden und Wälder in der Schweiz im späten 19. Jahrhundert. In Head-König, A.-L., Lorenzetti, L., Stuber, M., and Wunderli, R. (eds) Kollektive Weiden und Wälder. Ökonomie, Partizipation, Nachhaltigkeit (Histoire des Alpes / Storia delle Alpi / Geschichte der Alpen, Bd. 24), Zürich: Chronos, pp. 125-149.

Werthemann, A., and Imboden, A. 1982. Die Alp- und Weidewirtschaft in der Schweiz. Bern: Bundesamt für Landwirtschaft.

Wunderli, R. 2016. Berglandwirtschaft im Strukturwandel. Bauern/Bäuerinnen aus Ursern (UR) und politische Institutionen während der zweiten Hälfte des 20. Jahrhunderts. Altdorf: Gisler. 


\title{
3 How do the commons meet the state? A political science perspective
}

\author{
François-Xavier Viallon and Stéphane Nahrath
}

\subsection{Introduction}

In Switzerland, commoners' organisations have managed Alpine natural resources such as forests and meadows for long periods of time in a sustainable way (Mc Netting 1981). Drawing upon the analysis of Alpine and other commoners' organisations, Nobel Memorial Prize laureate Elinor Ostrom (1990, 2000) explained the survival of commoners' organisations by the consistency in the attributes of the resource system and the rules governing its users, who act primarily in a self-governed environment. Ostrom proposed eight design principles to explain the emergence and maintenance of commoners' organisations and successfully applied these principles to numerous cases across the globe. The publication of Ostrom's design principles initiated a global research trend for local governance structures. Among the theoretical currents that referred to Ostrom's principles, rational choice approaches - to which Ostrom belongs - and moral economy approaches (Scott 1976), have played a central role. However, various authors have also noted the shortcomings of these approaches. The lack of attention to power issues in commons research has been particularly highlighted (Cleaver 1999, Bakker 2008, Saunders 2014, Cleaver and de Koning 2015). There have also been warnings against a "commons" trap' (Schweizer 2018), according to which commoners' organisations would intrinsically produce social and ecological outcomes that are more desirable than those from other types of organisations. More specifically, Hall et al. (2014) note how rational choice and moral economy approaches seem oblivious to three elements. First, these approaches tend to neglect the heterogeneity of commoners' organisations. In practice, exclusive processes surround commoners' organisations, as neither membership, nor access to the resource, is open to all (Berkes 2006). Second, heterogeneous power relations characterise interactions among commoners, and one should not forget that arrangements at the core of commoners' organisations also result from negotiations and bargaining among commoners (Bakker 2008). Third, the relationship between commoners' organisations and the state is of high importance, as there are strong power interdependencies between these entities (Gerber et al. 2008). In other words, these approaches focus on the internal 
apolitical functioning of commoners' organisations and tend to ignore their interactions with the state and public policies.

The relationship between commoners' organisations and the state may involve Ostrom's eighth design principle, which suggests that it is important for commoners' organisations to organise into multiple layers of nested enterprises, both through horizontal and vertical connections (Cox et al. 2010). Acknowledging in particular the role of vertical connections, Ostrom listed three methods that larger systems may use to facilitate local self-organisation: "providing accurate information about natural resource systems, providing arenas in which participants can engage in discovery and conflict-resolution processes, and providing mechanisms to back up local monitoring and sanctioning efforts" (Ostrom 2000: 35). These three points were reiterated in the conclusion of The Future of the Commons (Ostrom et al. 2012: 81ff), but never extensively analysed in Ostrom's work. To account for such relationships, scholars introduced the notion of co-management (Berkes et al. 1991, Olsson et al. 2004), or extended Ostrom's analytical framework to discourses, as well as the political-economic context on international, national, regional, and local scales (Clement 2010). In line with Ostrom's suggestions, anthropological approaches defined a set of conditions to explain the long-term perpetuation of commoners' organisations in relation to the state. They identified recognition by local actors and legal protection by the state, as well as the support of the state to commoners' organisations, for example in the creation of open platforms for local debates, as necessary conditions (Landolt and Haller 2015, Haller et al. 2016, Haller et al. 2018, Kimengsi et al. 2019). Anthropologists analyse the emic perceptions of commoners' organisations that are engaging in the institution-building process. Overall, these approaches focus on the conditions for crafting institutions locally, and how external influence, such as the state and non-governmental organisations, may support their long-term perpetuation.

\subsection{Public policies to codify ownership, management, and use of natural resources}

The study of the interactions between commoners' organisations and the state seem of particular importance because the embeddedness of commoners' organisations managing natural resources into broader governance structures has increased over the past century. In fact, state legislation has progressively codified the ownership, management, and use rights of natural resources. In Switzerland, such codification took place at the beginning of the twentieth century through the definition of property rights to (natural) resources in the Federal Civil Code (Knoepfel and Schweizer 2015). Also, public policies specified possible resource uses, possible requirements, and restrictions (e.g. ranger patents for forest management, prohibition of clear cuts, hunting plans, and landscape protection). Since the 1970s, environmental policies have increased the number of regulations codifying the use, management, and ownership of natural resources (e.g. Knoepfel et al. 2001; Bolognesi and Nahrath 2020). Arising from the need to 
explain the effects of public policies and property rights on natural resource management, Swiss researchers used neo-institutional approaches and developed the Institutional Resource Regime (IRR) framework (Knoepfel et al. 2007; Gerber et al. 2009). According to the IRR framework, property rights and public policies both influence the exploitation and protection of natural resources, as they co-define the appropriation and use rights for natural resources. Property rights are recognised and enforced by the state and allow non-owners to be excluded; public policies implement policy instruments that specify, and often limit, the use rights of resource owners, potentially allocating use rights to non-owners (Varone and Nahrath 2014). The main assumption of the framework is that the coherent regulation of all goods and services produced by a natural resource increases the likelihood of its sustainable management (Gerber et al. 2009). The coherence or incoherence of a resource regime involves the degree of contradiction, lack of coordination, or lack of clarity of regulations affecting natural resource management. Whereas internal coherence relates to the fit between public policies, or to the fit between property rights, external coherence describes the fit between public policies and property rights. Incoherent resource regimes (i.e. incoherent policies and/or property rights) tend to produce regulations that are incompatible, and thus lead to the overuse of natural resources (Gerber et al. 2009). In other words, the IRR framework combines the lenses of institutional economics used by Ostrom with public policy analysis (Knoepfel et al. 2007). As a consequence, the framework may prove useful to analyse the interactions between commoners' organisations and the state.

An increasing number of researchers have applied the IRR framework to an analysis of natural resource management (Lieberherr et al. 2019), and more specifically to the analysis of common pool resources. The common pool resources under analysis include, for example, land in common property (Knoepfel et al. 2001, Gerber et al. 2008, Gerber et al. 2011), forests owned by commoners' organisations (Bisang 2001, de Buren 2014), landscape (Rodewald 2004, Gerber and Knoepfel 2008), wildlife (Nahrath et al. 2012), housing (Nicol and Knoepfel 2014, Balmer and Gerber 2018), and water (Aubin 2008, Garin and Barraqué 2012, Schweizer 2015, Nahrath and Bréthaut 2016, Bolognesi and Pflieger 2019). Research applying the IRR framework to CPR analysis sheds light on the relationship between commoners' organisations and the state, and the (positive or negative) impact of public policies on the survival of commoners' organisations. Researchers have distinguished four types of interactions between commoners' organisations and the state, which are described below.

\subsection{Four modalities of interaction between the commons and the state}

\subsubsection{Translation}

Commoners' organisations may act as intermediaries in the implementation of public policies. While intermediaries might play different roles in policy 
implementation processes (Bendor 2009, Coggan et al. 2013, Shahab and Viallon 2020), commoners' organisations can act as translators of public policy objectives into the local understanding of resource owners targeted by public policy instruments (Nahrath et al. 2012). Such an act may be explained by the fact that members of commoners' organisations are also targeted by the considered public policy or policies. The translation of policy objectives involves modifying a pre-existing hierarchy of norms and providing legitimacy to a new, adapted hierarchy (Jobert and Muller 1987: 73). Such modification of the hierarchy of norms may work in two directions. Commoners' organisations may, for example, modify the local hierarchy of norms by translating national policy objectives into local norms: into the beliefs and practices of local actors. In a case comparison of hunting associations in charge of managing wildlife in Switzerland, Nahrath et al. (2012) observed that representatives of common-pool organisations managing wildlife acted as intermediaries between state representatives and hunters in charge of implementing cantonal wildlife policy objectives. Created at the beginning of the twentieth century, these self-organised hunters associations have responsibility for the wildlife stock within specific regions. As the study shows, they proved more effective than the permit-based regulations, or state-managed systems which apply in other Swiss cantons. Further drawing on cases analysing the functioning of secular common dyke associations protecting land from floods in Bern canton, Gerber et al. (2008) observed how these corporations effectively represented landowners as members of the association in the flood protection policy. Association representatives were able to translate the interests of involved actors towards both the municipality and the cantonal administration, as well as towards their own members. The authors observed how these commoners' organisations made policy target groups (i.e. its members) aware of their responsibilities regarding flood protection, and influenced their belief systems and behaviours in policy processes (Gerber et al. 2008). The overall results of these studies suggest that: if (1) the property rights of commoners' organisations are clearly defined and recognised by the state, and (2) commoners' organisations are part of local political-administrative arrangements implementing public policies, then commoners' organisations may increase the effectiveness of policy outcomes.

\subsubsection{Infusion}

Commoners' organisations might also contribute to reducing rivalries regarding the use of common pool resources among distinct groups of resource users by infusing CPR-related practices and knowledge into the public organisations in charge of policy implementation (Bréthaut 2013, Nahrath and Bréthaut 2016). The case of water governance in the mountain area of Crans-Montana, Valais, shows how municipal organisations circumvent situations of water scarcity during consumption peaks in the tourist season. To avoid water shortages, representatives of several municipalities in Crans-Montana had to reach 
a flexible agreement on water exchange. Several of the municipal representatives held positions in commoners' organisations that had owned and managed water rights for centuries. These organisations were responsible for sharing water among farmers, primarily for agricultural purposes, and, therefore, their members who worked as representatives of the municipal water organisations were familiar with concluding quick and flexible oral agreements on the use of water. Some representatives were also acquainted with each other. These two factors allowed municipal representatives to share their knowledge of water management from commoners' organisations within an (official) intermunicipal committee. This committee was entitled to make temporary informal agreements on the use of water in situations of scarcity, and rapidly transfer water flows from one municipality to another. As a consequence, the practical knowledge, and the network of trust stemming from commoners' organisations, was infused into a larger inter-municipal system, which allowed temporary situations of resource scarcity to be overcome.

\subsubsection{Complementarity}

Thirdly, commoners' organisations may complement existing policies and public sector organisations (Blomquist 1992, Gerber et al. 2011). This function may increase the effectiveness of policies, in particular when facing policy problems that crosscut the traditional boundaries of policy sectors, administrative organisations, territories, and/or scales (Jochim and May 2010, Levin et al. 2012). For example, commoners' organisation may increase the effectiveness of policy implementation by providing additional administrative capacities, monitoring mechanisms, or knowledge of local environmental conditions (Howlett and Saguin 2018, Söderberg 2011). Gerber et al. (2011) observed how commoners' organisations owning urban land in areas intended for development supported the implementation of municipal land-use planning policy. When opening new land for urbanisation, Swiss municipalities establish a strategic plan, and allocate development rights on land through zoning. In the cities of Bern and Chur, significant amounts of land, including land dedicated to urbanisation, is owned by commoners' organisations. In accordance with municipal planning objectives and calendars, these commoners' organisations made their zoned land available for sale/rent, often for the development of affordable housing, or to regional industries. In certain cases, commoners' organisations even used their financial autonomy and higher budget flexibility to acquire plots of land on behalf of municipalities. Such behaviour shows how commoners' organisations may use their infrastructure and/or financial resources to support the implementation of municipal land use policy goals.

\subsubsection{Resistance}

A fourth and last modality of interaction between commoners' organisations and the state is the resistance of commoners' organisations to the implementation 
of public policies, as the case of Alpine pastures in Canton Uri and Obwalden shows (Viallon et al. 2019). Since the end of the nineteenth century, the size of the areas under management, the shrinking profitability of agriculture uses, and financial and infrastructure costs of servicing the land, have challenged both the maintenance of Alpine pastures and the perpetuation of agricultural activities. From a policy perspective, however, the use of pasture was necessary for various objectives, such as agricultural production and the preservation of employment, the prevention of avalanches, and landscape maintenance in support of emerging tourism activities. As resource owners and users, commoners' organisations were the only organisations able to achieve these goals. Such a (relatively) powerful position reflects the secular separation of forestry and pasturing activities. In ancient practices, cattle were pastured in forest areas. This practice has been incompatible with forest management policy until recently (Pfister and Brändli 1999, Stuber 2020; Knoepfel and Nahrath 2017). In fact, the overlap of pasturing activities and forest management was perceived as a cause of the nineteenth-century floods in Switzerland. The separation of these two uses was only achieved a long time after its definition, in some cases only in the second half of the twentieth century (Viallon et al. 2019). These cases show diverging interests between the commoners' organisation and the state, and how rather strong commoners' organisations may successfully resist to the implementation of public policies.

\subsection{Conclusion}

In summary, policy analysis offers four ways to approach interactions between the commons and the state. This chapter first described the existing research paths in political science that expand upon more traditional economic approaches to common pool resource management. It then briefly introduced the IRR framework as a resource-based approach that accounts for the institutional environment of commoners' organisations. The latter has proven a useful heuristic tool that allows the interplay of public policies and property rights to be tested in empirical situations of natural resource management. The third part of the chapter described four modes of interaction identified by the IRR approach between commoners' organisations and the state: translation, infusion, complementarity, and resistance. To date, these modes of interaction have been applied to a limited number of research projects and publications, whereas understanding interactions between commoners' organisations and the state in Western liberal democracies is crucial for three reasons. First, common property today could not exist without its recognition in law, which is defined by the state. Therefore, considering the state as a key actor in the perpetuation of the commons is essential. Second, the increasing heterogeneity of resource uses may create rivalries with external users, making it necessary to analyse the conflict resolution mechanisms defined by the state and the rule of law to solve them. Finally, the 'shadow of the state' and its structuring role in negotiations may facilitate - or not - self-organised behaviour (Scharpf 1994). 
In the case of the commons, the impact of the state's 'shadow' on commoners' organisations is still to be determined. It therefore seems particularly relevant to pay attention to the described modes of interaction. This book offers a timely opportunity to expand the empirical foundations of these modes, which we believe can improve existing explanations of why and how commoners' organisations emerge, perpetuate, or collapse in a complex legal setting increasingly shaped by public policies.

\section{References}

Aubin, D. (2008) 'Asserted Rights; Rule Activation Strategies in Water User Rivalries in Belgium and Switzerland', Journal of Public Policy, vol 28, no 2, pp 207-227.

Bakker, K. (2008) 'The Ambiguity of Community: Debating Alternatives to Private-sector Provision of Urban Water Supply', Water Alternatives, vol 1, no 2, pp 236-252.

Balmer, I. and Gerber, J.-D. (2018) 'Why are Housing Cooperatives Successful? Insights from Swiss Affordable Housing Policy', Housing Studies, vol 33, no 3, pp 361-385. doi: 10.1080/02673037.2017.1344958.

Bendor, T. (2009) 'A Dynamic Analysis of the Wetland Mitigation Process and Its Effects on No Net Loss Policy', Landscape and Urban Planning, vol 89, no 1, pp 17-27. doi: 10.1016/j.landurbplan.2008.09.003.

Berkes, F. (2006) 'From Community-Based Resource Management to Complex Systems: The Scale Issue and Marine Commons', Ecology and Society, vol 11. http://www.ecol ogyandsociety.org/vol11/iss1/art45/

Berkes, F., George, P. and Preston, R. J. (1991) 'Co-management: The Evolution in Theory and Practice of the Joint Administration of Living Resources', Alternatives, vol 18, no 2, pp 12-18.

Bisang, K. (2001) 'Historische Entwicklung der institutionellen Regime des Waldes zwischen 1870 und 2000' in Kissling-Näf, I., Knoepfel P. and Varone, F. (eds), Institutionelle Regime für natürliche Ressourcen: Boden, Wasser und Wald im Vergleich (pp141-182). Basel: Helbing \& Lichtenhahn.

Blomquist, W. (1992) Dividing the Waters: Governing Groundwater in Southern California. San Francisco: ICS Press.

Bolognesi, T. and Nahrath, S. (2020) 'Environmental Governance Dynamics: Some Micro Foundations of Macro Failures', Ecological Economics, vol 170, p. 106555. doi: 10.1016/j. ecolecon.2019.106555.

Bolognesi, T. and Pflieger, G. (2019) 'The Coherence(s) of Institutional Resource Regimes: Typology and Assessments from the Case of Water Supply Management', Environmental Science and Policy, vol 99, pp 17-28. doi: 10.1016/j.envsci.2019.05.003.

Bréthaut, C. (2013) 'Le fonctionnement du réseau d'eau d'une station touristique: spécificités et réinterprétation locale des règles', Flux, vol 92, no 2, pp 36-46.

Cleaver, F. (1999) 'Paradoxes of Participation: Questioning Participatory approaches to Development', Journal of International Development: The Journal of the Development Studies Association, vol 11, no 4, pp 597-612.

Cleaver, F. and De Koning, J. (2015) 'Furthering Critical Institutionalism', International Journal of the Commons, vol 9, no 1, pp 1-18. doi: 10.18352/ijc.605.

Clement, F. (2010) 'Analysing Decentralised Natural Resource Governance: Proposition for a "Politicised" Institutional Analysis and Development Framework', Policy Sciences, vol 43, no 2, pp 129-156. 
Coggan, A., Buitelaar, E., Whitten, S. M. and Bennett, J. (2013) 'Intermediaries in Environmental Offset Markets: Actions and Incentives', Land Use Policy, vol 32, pp 145-154. doi: 10.1016/j.landusepol.2012.10.002.

Cox, M., Arnold, G. and Villamayor Tomás, S. (2010) 'A Review of Design Principles for Community-Based Natural Resource Management', Ecology and Society, vol 15, no 4, art 38. doi: 10.5751/ES-03704-150438.

De Buren, G. (2014) La gestion des services environnementaux: entre règles et régulation négociée. Six études de cas de services forestiers pour la production d'eau potable dans trois pays. $\mathrm{PhD}$ thesis, University of Lausanne. https://serval.unil.ch/resource/serval:BIB_1DC91F56E280 .P001/REF.

Garin, P. and Barraqué, B. (2012) 'Why Are There so Few Cooperative Agreements Between Farmers and Water Services in France? Water Policies and the Problem of Land Use Rights', Irrigation and Drainage, vol 61, no 1, pp 95-105. doi: 10.1002/ird.1657.

Gerber, J.-D. and Knoepfel, P. (2008) 'Towards Integrated Governance of Landscape Development', Mountain Research and Development, vol 28, no 2, pp 110-115. doi: 10.1659/mrd.0938.

Gerber, J.-D., Knoepfel, P., Nahrath, S. and Varone, S. (2009) 'Institutional Resource Regimes: Towards Sustainability through the Combination of Property-rights Theory and Policy Analysis', Ecological Economics, vol 68, no 3, pp 798-809. doi: 10.1016/j. ecolecon.2008.06.013.

Gerber, J.-D., Nahrath, S., Csikos, P. and Knoepfel, P. (2011) 'The Role of Swiss Civic Corporations in Land-Use Planning', Environment and Planning A: Economy and Space, vol 43, no 1, pp 185-204. doi: 10.1068/a43293.

Gerber, J.-D., Nahrath, S., Reynard, E. and Thomi, L. (2008) 'The Role of Common Pool Resource Institutions in the Implementation of Swiss Natural Resource Management Policy', International Journal of the Commons, vol 2, no 2, pp 222-247.

Hall, K., Cleaver, F., Franks, T. and Maganga, F. (2014) 'Capturing Critical Institutionalism: A Synthesis of Key Themes and Debates', The European Journal of Development Research, vol 26, no 1, pp 71-86. doi: 10.1057/ejdr.2013.48.

Haller, T., Acciaioli, G., and Rist, S. (2016) 'Constitutionality: Conditions for Crafting Local Ownership of Institution-Building Processes', Society \& Natural Resources, vol 29, no 1, pp 68-87. doi: 10.1080/08941920.2015.1041661.

Haller, T., Belsky, J. M. and Rist, S. (2018) 'The Constitutionality Approach: Conditions, Opportunities, and Challenges for Bottom-Up Institution Building', Human Ecology, vol 46, no 1, pp 1-2. doi: 10.1007/s10745-018-9966-1.

Howlett, M. P. and Saguin, K. (2018) Policy Capacity for Policy Integration: Implications for the Sustainable Development Goals. Rochester: Social Science Research Network. doi: 10.2139/ssrn. 3157448 .

Jobert, B. and Muller, P. (1987) L'Etat en action. Paris: Presses Universitaires de France. https ://halshs.archives-ouvertes.fr/halshs-00137940/document.

Jochim, A. and May, P. (2010) 'Beyond Subsystems: Policy Regimes and Governance', Policy Studies Journal, vol 38, no 2, pp 303-327.

Kimengsi, J. N., Aung, P. S., Pretzsch, J., Haller, T. and Auch, E. (2019) 'Constitutionality and the Co-Management of Protected Areas: Reflections from Cameroon and Myanmar', International Journal of the Commons, vol 13, no 2, pp 1003-1020. doi: 10.5334/ijc.934.

Knoepfel, P., Kissling-Näf, I. and Varone, F. (2001) Institutionelle Regime für natürliche Ressourcen: Boden, Wasser und Wald / Régimes institutionnels de ressources naturelles : analyse comparée du sol, de l'eau et de la forêt. Vol 17. Basel and Frankfurt: Helbing und Lichtenhahn. 
Knoepfel, P. and Nahrath, S. (2017) 'Le gibier, la forêt et les chasseurs à la lumière des régimes institutionnels (essai)', Schweizerische Zeitschrift fur Forstwesen, vol 168, no 4, pp 176-180.

Knoepfel, P., Nahrath, S. and Varone, F. (2007) 'Institutional Regimes for Natural Resources: An Innovative Theoretical Framework for Sustainability' in Knoepfel, P. (ed.), Environmental Policy Analyses: Learning from the Past for the Future -25 Years of Research (pp 455-506). Berlin, Heidelberg: Springer Berlin Heidelberg. doi: 10.1007/978-3-540-73149-8_15.

Knoepfel, P. and Schweizer, R. (2015) 'Le local et le global: quatre défis de la codification du droit foncier dans le cadre du processus de rédaction du Code civil suisse de 1907' in Travési, C. and Ponsonnet, M. (eds), Les conceptions de la propriété foncière à l'épreuve des revendications autochtones: possession, propriété et leurs avatars ( $\mathrm{pp}$ 79-93). Marseille: PacificCredo Publications.

Landolt, G. and Haller, T. (2015) 'Alpine Common Property Institutions under Change: Conditions for Successful and Unsuccessful Collective Action by Alpine Farmers in the Canton of Grisons, Switzerland', Human Organization, vol 74, no 1, pp 100-111.

Levin, K., Cashore, B., Bernstein, S. and Auld, G. (2012) 'Overcoming the Tragedy of Super Wicked Problems: Constraining Our Future Selves to Ameliorate Global Climate Change', Policy Sciences, vol 45, no 2, pp 123-52.

Lieberherr, E., Fischer, M. and Tschannen, A. (2019) 'Taking Stock of Institutional Resource Regime Research: A Meta-Analysis', Environmental Science E Policy, vol 97, pp 81-89. doi: 10.1016/j.envsci.2019.04.003.

Mc Netting, R. (1981) Balancing on an Alp. Ecological Change and Continuity in a Swiss Mountain Community. Cambridge: Cambridge University Press.

Nahrath, S., Gerber, J.-D., Knoepfel, P. and Bréthaut, C. (2012) 'Gestion des ressources communes en Suisse: le rôle des institutions de gestion communautaire dans les politiques environnementales et d'aménagement du territoire', Natures sciences sociétés, vol 20, no 1, pp 39-51.

Nahrath, S. and Bréthaut, C. (2016) 'Coordination Between Institutional Resource Regimes as a Condition for Sustainable Management of Alpine Touristic Resources: The Case of Crans-Montana (Switzerland)', Revue de Géographie Alpine, vol 104, no 3. https://archive-ouverte.unige.ch/unige:90818.

Nicol, L. and Knoepfel, P. (2014) 'Resilient Housing: A New Resource-Oriented Approach', Building Research and Information, vol 42, no 2, pp 229-239.

Olsson, P., Folke, C. and Berkes, F. (2004) 'Adaptive Comanagement for Building Resilience in Social-Ecological Systems', Environmental Management, vol 34, no 1, pp 75-90. doi: 10.1007/s00267-003-0101-7.

Ostrom, E. (1990) Governing the Commons. The Evolution of Institutions for Collective Action. Cambridge: Cambridge University Press.

Ostrom, E. (2000) 'Reformulating the Commons', Swiss Political Science Review, vol 6, no 1, pp 29-52. doi: 10.1002/j.1662-6370.2000.tb00285.x.

Ostrom, E., Chang, C., Pennington, M. and Tarko, V. (2012) The Future of the Commons: Beyond Market Failure and Government Regulation. Rochester: Social Science Research Network. doi: 10.2139/ssrn.2267381.

Pfister, C. and Brändli, D. (1999) 'Rodungen im Gebirge. Überschwemmungen im Vorland. Ein Deutungsmuster macht Karriere' in Sieferle, R. and Breuninger, H. (eds), Naturbilder: Wahrnehmungen von Natur und Umwelt in der Geschichte (pp 291-324). Frankfurt am Main: Campus. 


\section{François-Xavier Viallon and Stéphane Nahrath}

Rodewald, R. (2004) Veränderung des institutionellen Ressourcenregimes der Landschaft: der Fall Val Mora/Müstair (GR). Lausanne: IDHEAP.

Saunders, F. (2014) 'The Promise of Common Pool Resource Theory and the Reality of Commons Projects', International Journal of the Commons, vol 8, no 2, pp 636-656. doi: 10.18352/ijc. 477.

Scharpf, F. W. (1994) 'Games Real Actors Could Play: Positive and Negative Coordination in Embedded Negotiations', Journal of Theoretical Politics, vol 6, no 1: 27-53. doi: 10.1177/0951692894006001002.

Schweizer, R. (2015) 'Law Activation Strategies (LAS) in Environmental Policymaking: A Social Mechanism for Re-Politicization?', European Policy Analysis, vol 1, no 2, pp $132-54$.

Schweizer, R. (2018) 'Avoiding the Commons Trap: An Exploration of Local Community Governance of Water in Valais, Switzerland' in Bréthaut, C. and SChweizer, R. (eds), $A$ Critical Approach to International Water Management Trends: Policy and Practice (pp 23-44). London: Palgrave Macmillan. doi: 10.1057/978-1-137-60086-8_2.

Scott, J. C. (1976) The Moral Economy of the Peasant: Rebellion and Subsistence in Southeast Asia. Yale: Yale University Press. https://www.jstor.org/stable/j.ctt1bh4cdk.

Shahab, S. and Viallon, F.-X. (2020) 'Swiss Land Improvement Syndicates: 'Impure' Coasian Solutions?', Planning Theory. doi: 10.1177/1473095220923629.

Söderberg, C. (2011) 'Institutional Conditions for Multi-Sector Environmental Policy Integration in Swedish Bioenergy Policy', Environmental Politics, vol 20, no 4, pp 528546. doi: 10.1080/09644016.2011.589625.

Stuber, M. (2020) 'La forêt - Évolution de la haute surveillance sur la police des forêts : de la forêt vivrière à la forêt des forestiers' in Mieg, H. A. and Haefli, U. (eds), La politique environnementale en Suisse. De la police des forêts aux écobilans (pp 35-54). Bâle: NZZ Libro.

Trein, P., Biesbroek, R., Bolognesi, T., Cejudo, G. M., Duffy, R., Hustedt, T. and Meyer, M. (2020) 'Policy Coordination and Integration: A Research Agenda', Public Administration Review. doi: 10.1111/puar.13180.

Varone, F. and Nahrath, S. (2014) 'Regulating the Uses of Natural Resources. When Policy Instruments Meet Property Rights' in Halpern, C., Lascoumes, P. and Le Galès, P. (eds), L'instrumentation de l'action publique: Controverses, résistances, effets (pp 237-264). Paris: Presses de Sciences Po.

Viallon, F.-X., Liechti, K., Stuber, M. and Wunderli, R. (2019) 'Vermittlung, Einbau, Komplementarität - Formen des staatlichen Zugriffs auf kollektive Wälder und Weiden in der Schweiz im späten 19. Jahrhundert', Histoire des Alpes - Storia delle Alpi-Geschichte der Alpen, vol 24, pp 125-149. 


\title{
4 Commons and peasant studies: Insights from social anthropology, human geography and agrarian economics
}

\author{
Tobias Haller, Karina Liechti and Stefan Mann
}

\subsection{Introduction}

This chapter outlines how research into the Swiss commons integrates approaches studying peasant societies and their management of common-pool resources based on a fusion of the theories from economic and political anthropology, human geography and agrarian economics. These disciplines, and their approaches, are important because our fieldwork brought challenges regarding the angle from which to analyse commons management in a context of politically secured tenure, unlike that in many areas of the world, especially in the global south. This context leads to specific reflections that somehow exclude consideration of the link between the overuse of resources and tenure insecurity, which is often debated in commons studies. In Switzerland, however, we more commonly deal with perceptions of market and state actors in a rapidly changing socio-economic and political environment that has reduced the perceived value of the commons and its related "traditional" products such as dairy, meat and timber. On the one hand, this pressures commoners to rethink their economic strategies, above all the imbalance between costs and gains from the commons. On the other hand, they have to rethink issues related to identity - as they are a minority controlling, using and maintaining a large area of cultural landscape in Switzerland, and it is necessary to address increased societal concerns and demands such as for environmental protection, economic efficiency and social justice. Such important issues are often dealt with based on the notion of rationality, adaptation and resilience, however, we realised that we need to provide different elements of analysis in order to avoid an overly simplistic interpretation of the changes and strategic actions followed by individuals and groups concerned. While we do not contest the principles of bounded rationality in economics, actions are not only influenced by economic values in the monetary sense but also by socio-cultural values. We therefore do not want to underestimate the importance of understanding the multiple local perceptions and meanings ascribed to community and resources and the power positions/relations in which the actors are finding themselves. Such values are not produced in a void, but relate to the identity of individuals and groups and interact with the wider world, as well as broadly changing social values. 


\subsection{A brief look at peasant studies}

Although we do not have the space here to go into the vast literature of peasant studies, we will try to highlight some of the ways that so-called peasant societies are working economically and socially apart from the analysis of evolutionist, culturalist and Marxist reflections. Cancian (1989) provides an overview in which he indicates the different waves of conceptualising economic behaviour of farming communities. There is a range of studies on farming communities in social anthropology, examining communities that are relatively independent of state and market pressures (ibid.). Their strategies rely mainly on subsistence production and their adaptation to natural as well as political environmental constellations, leading to a set of specific strategies that are designed to cope with insecurity and political instability. This double coping process has implications for the economic strategies selected by peasants and for the tenure aspect of farming communities and the way agricultural production is shaped in extensive (with high mobility) or intensive (low mobility and high level of sedentary strategies) agrarian production systems. According to the vast and global social anthropological literature, mainly subsistence-oriented farming communities, as well as so-called peasants (famers integrated in market and state contexts), have a basic strategy in common: they have to balance between the utility of production for subsistence (as well as for state and market) on the one hand, and the drudgery of the workload itself, on the other hand. This insight led the Russian agro-economist Alexander Chayanov in the 1920s to adopt the view of a peculiar peasant economy, which was in contradiction to the Marxist view of Lenin, who perceived peasants as "small capitalists" (Kerbely 1984). Chayanov's view was based on statistical work on land use among farmers in Russia, and he stated that peasants work just as much land and produce as many crops as will meet the demand for feeding a family, and that producing more than the amount needed to cover these needs would, in economic terms, be irrational, as the drudgery of the work exceeds the utility of subsistence production. This means that peasants stop producing more crops, working more land and using more energy for production when their needs are met and the workload is, emically (from the local perspective), perceived as being too high. This is depicted in the simple graph in Figure 4.1, which shows the marginally decreasing curves for the subsistence utility and the increasing curve for the drudgery function. Working more land and producing more only make sense, from a peasant-economics point of view, when the family has children and the parents need to work harder to feed them. This imbalance of fewer producers and more consumers in the household levels out as the children grow older and eventually leave their parent's home. According to Chayanov, there is therefore no accumulation.

This model was much contested in the Soviet Union, and Chayanov's sad fate was to be put in detention for his empirical views and statistics. By the end of the 1960s, however, scholars such as Kerbely (1984) and Shanin (1973/74) had translated and further developed the model to also be applicable to studies 


\section{Chayanov's model of peasant economics}



Figure 4.1 Chayanov's model of peasant economics. Source: Haller (2001), based on Chayanov in Kerbley (1984).

of peasants in market and state economies. It included new ideas and new insights into what peasants were working for, including risk reduction (minimax strategies), adaptation to the market and state actors and their demands. Chayanov's model provides a basis for further reflection, as it is a first attempt to show the rationality of sufficiency strategies, and sufficiency is an important aspect of the governance of common-property institutions.

\subsection{Commons studies and new institutional economics}

When dealing with the interrelationship between private and common property and land-related common-pool resources (CPRs), the Nobel Prize-winning work Governing the Commons (1990) by Elinor Ostrom deserves in-depth discussion. In this approach, which is part of what is called New Institutionalism (NI) (see Haller 2007, 2010), she elaborates on her notion of design principles for locally established long-enduring institutions (rules and regulations) for the management of CPRs such as pastures and forests. These principles for robust institutions are summarised in Table 4.1.

Ostrom's work is mostly based on case studies from social anthropology and human geography, of which Robert Netting's (1981) work on the management of pastoral commons is a cornerstone. These studies show that common property institutions can reduce transaction costs for collective actions 
Table 4.1 Design principles derived from studies of long-enduring institutions for governing sustainable resources

1 Clearly defined boundaries

The boundaries of the resource system (e.g. groundwater basin or forest) and the individuals or households with rights to harvest resource products are clearly defined.

\section{Proportional equivalence between benefits and costs}

Rules specifying the number of resource products that a user is allocated are related to local conditions and to rules requiring labour, materials, and/or monetary input.

3 Collective-choice arrangements

Most individuals affected by harvesting and protection rules are included in the group, who can modify these rules.

4 Monitoring

Monitors, who actively audit physical conditions and user behaviour, are at least partially accountable to the users and/or are the users themselves.

\section{Graduated sanctions}

Users who violate rules are likely to receive graduated sanctions (depending on the seriousness and context of the offense) from other users, from officials accountable to these users, or from both.

6 Conflict-resolution mechanisms

Users and their officials have rapid access to low-cost, local arenas to resolve conflict between users, or between users and officials.

\section{Minimal recognition of rights to organise}

The rights of users to devise their own institutions are not challenged by external governmental authorities, and users have long-term tenure rights to the resource.

8 For resources that are parts of larger systems

\section{Nested enterprises}

Appropriation, provision, monitoring, enforcement, conflict resolution and governance activities are organised in multiple layers of nested enterprises.

Source: Ostrom (1990: 56f.)

that make sustainable use of the commons possible, and contradict the view that common property must lead to the overuse of CPRs as described in Hardin's famous polemic called The Tragedy of the Commons (see Ostrom 1990). Ostrom further extended her approach to an Institutional Analysis and Development (IAD) framework (Ostrom 2005) in order to explain institutional diversity. However, this approach has been criticised, particularly by social anthropologists, for not addressing different levels of interactions such as historical and external economic, as well as political changes and power relations between actors. Such features, in our view, need to be incorporated in order to explain why institutions change and which actors with which power relationships drive that change (see Haller 2013; Olivier de Sardan 2013; Cleaver 2003).

Drawing on this critique, the theoretical framework of the New Institutionalism approach in economic anthropology (Ensminger 1992; Haller 
2010, 2013) incorporates issues of change and power relations. Here, institutional change is linked to external factors (i.e. the natural, political and economic environment, demographic and technological factors), which can change relative prices (valuation of resources or areas related to others). In addition, institutional change has an impact on, and is shaped by, internal factors, which in turn influence the actors using the commons. These internal factors include elements such as an actor's bargaining power and ideologies. The latter consists of the discourses and narratives used by actors to justify the selection of specific institutions for the management of common pool resources. Such discourses and narratives include, for example, favouring values of modern neo-liberal economics opting for private property, versus communal or participatory approaches opting for common property providing ecological services. Such ideological processes, as well as differences in the bargaining power of actors which can be strengthened or weakened by ideologies - have an important impact on the way actors perceive, organise, select and craft institutions (see Figure 4.2). This power-sensitive New Institutionalism approach also offers an analytical framework to explain institutional and organisational challenges, choices and practices and related coping and adaptation strategies dealing with the multiple challenges that Swiss commoners organisations are facing.

Swiss studies show how actors have reorganised and differentiated their use of common and private properties in alpine areas under changing economic and political conditions. Baur, Liechti and Binder (2014), for instance, conclude that the increasing size of farms means that farmers are reducing their use and maintenance of common property. At the same time, those individuals who use a resource intensively and benefit most from it also have the greatest interest in maintaining resource productivity in the long term, and thus apply and enforce pro-social behaviour. Baur and Binder (2013) also show that constitutional flexibility allows the governance system to adapt its structure

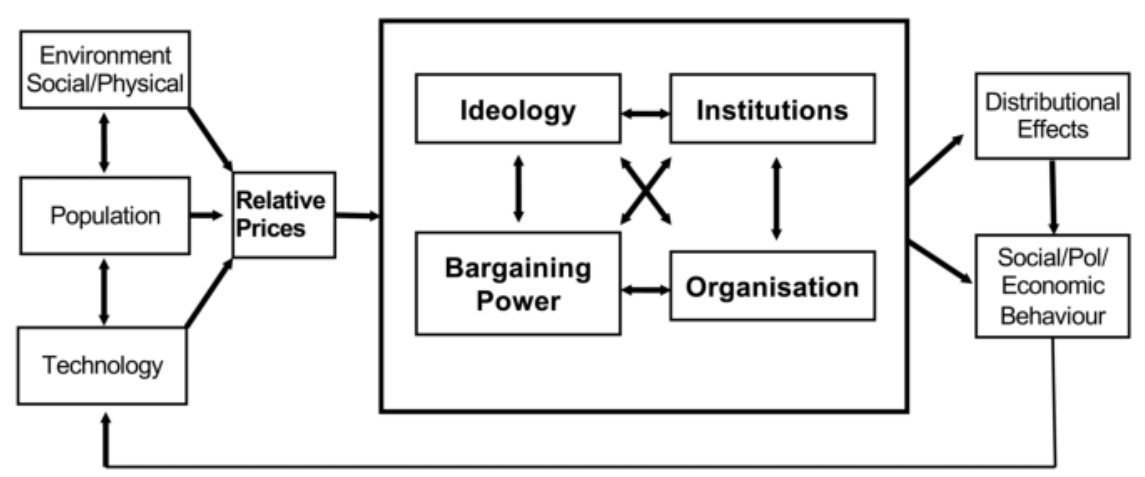

Figure 4.2 Modelling institutional change. Source: Ensminger (1992: 10), revised in Haller (2013). 
to problems such as decreasing bargaining power. As an example, the creation of an additional governing level, such as a pasture users' association, has allowed farmers to govern the agricultural affairs of the corporation without the involvement of tourism entrepreneurs. Research into the governance of water channel irrigation systems in the Valais has produced evidence of a diversity of commons institutions and practices - from "traditional" cooperative to diversified hybrid and public models - that are still present nowadays (Schweizer et al. 2014). The authors show that the challenge of today's water channel management lies in the increasing heterogeneity of resource users, which makes them more vulnerable to conflict than the former homogeneous groups. While small and less complex systems could be managed in a relatively stable manner, today's institutional resource regimes cannot be operated exclusively by users and without public policies and contributions. Tiefenbach (2013) notes the importance of the social dimension in collective bodies in a rapidly changing socio-economic and political environment: by always returning and working together on the alp, a relationship is created within a community and with a particular landscape.

In a comparative study on the use of common pastures in two alpine villages in the canton of Grisons, Landolt and Haller (2015) similarly focussed on this heterogeneity of commoners' organisations by using the EnsmingerHaller framework. In one village, conflict arose when the cooperative work needed to maintain common pastures was neglected. This failure of collective action resulted from farmers' groups with lower bargaining power and with a poor reputation within the municipality (the ideology of the commoners' organisations being backward-oriented and a narrative of bad management of the commons). In the other village, farmers have enough bargaining power to challenge the interests of other users. Coupled with the capacity to self-organise, be innovative and devise new institutions to cope with market and political changes, these farmers can assert themselves better than their colleagues in the first village (Landolt and Haller 2015) and are also able to devise new bottom-up-driven institutions. This case study also illustrates the constitutionality approach (developing a sense of ownership in the institution-building process) that is researched in other global contexts (Haller 2016). The most common issue in this latter research is the way institutions could or could not endure massive economic and political changes and shocks - and therefore performed different degrees of resilience. The Swiss cases show that commoners' organisations have to adapt to societal and economic change on the one hand, and that on the other hand, they show that the decentralised political system also allows local collective entities to craft their own institutions.

While social anthropological and human geography studies focus on issues of self-organisation, institutional adaptation and innovation by also including an emic perception, agrarian economics looks at economic resilience as an indicator of the sustainability of institutions and related forms of economic organisation. Together with law, theology and ethics, economics is one of the few normative branches of science, and its utilitarian focus on profits, private 
property and private economic organisation and their added value has provoked the critique of being a "reductionist" science (Diaw 2005; Katzenstein 2009), but has also enabled a distinction between successful and failed strategies. From this viewpoint, the most visible advantage of CPRs is that they can easily exploit economies of scale. The profitable agriculture in East Germany that still relies greatly on cooperative institutions (Wolz et al. 2009) is a case in point. In Switzerland, Lips et al. (2008) were able to show that cooperative farms (usually a merger between two or three family farms) are usually more successful than family farms due to scale effects.

Newer economic literature, including Powell (1990), does not, however, focus on economic performance alone, and only on common property compared to private property institutions, but highlights the fact that cooperation as a form of organisation in different systems plays a role in economic performance (see also Mann 2011). Related economic literature (see summary in ibid.) focuses on the degree of interaction between these property systems in the long term, on robust cases. This is of central interest and needs to be related to forms of organisation and success and failure in the market. Janssen and Ostrom (2006) mention "governments, communal groups, cooperatives, voluntary associations, and private individuals or firms" as possible organisational forms for governing common pool resources. Not all of these organisational forms are equally well suited to studying the governance of CPRs from an economic viewpoint, taking economic efficiency into account. In this economic context, the focus of research has shifted from hierarchical firms to acknowledge the fact that commoners' organisations have emerged as a setting that is emphasising the commonality and equality of their members. It is therefore useful to first concentrate on the literature about commoners' organisations when studying CPR use from an economic perspective.

First, while neo-classical theory focuses on individually achieved profit as the most important indicator of the success of an enterprise, left-wing social scientists repeatedly emphasise the "distributional conflict" (Capaldo 2007) or "conflictual relationship" (Ortu 2008) between profits and wages. For most forest cooperatives, the ability to pay acceptable wages is an indicator of success, while the situation is more complex for cooperative alpine summer pastures. Alpine corporations receive part of their turnover from sales of cheese and another part from reimbursements from the farmers who send their cows to the pasture and are often members of the corporation. They also receive some subsidies from the state (so-called "direct payments for summering"). Wages have to be paid to the alpine herder and cheese maker for care and production. The utility is therefore different than, for example, that for forestry. It is interesting to see that the older literature on success indicators of forest, fisheries and agricultural cooperatives, such as standard textbooks, usually refer to profit as the central indicator (Bergen et al. 2013), while an alpine pasture calculation has to be made in a different way, balancing more between care as a service and the production of milk and cheese (Theuvsen and Franz 2007; Henriksen et al. 2012). Second, other approaches 
define success differently, looking at emic perceptions of the members, such as their satisfaction (Poggie et al. 1988; Amini and Ramezani 2008; Zarafshani et al. 2010) in line with social anthropological approaches. A third line of thought sees the longevity of commoners' organisations - which is in line with Ostrom's notion of robustness - as the most important factor (Barton et al. 2011; Hertz 2011), and a fourth approach focuses on the sustainable use of CPRs (Dietz et al. 2003). These four different approaches (monetary, including issues of differentiated care/production/share economy/psychological, historic and environmental), which look at success as related to profit of cooperatives, can therefore be differentiated; however, they do not look at power relations.

\subsection{Combining New Institutionalism with political geography, economics and ecology}

As outlined in the previous chapter, Ostrom's approach, as well as economic approaches, largely neglect power on all levels. While the New Institutionalism approach focuses on bargaining power and is further ahead than other more normative approaches in economics (see Williamson 1987) in this respect, it still lacks a more nuanced consideration of power relations between actors on several scales. Critical political branches in economics, geography, social anthropology and ecology focus on power relations and their effects on the way ideology shapes discourses and narratives regarding what nature is and how the results of human-nature interaction shall be interpreted (see Haller 2019a). It is thus an issue of the perception of nature and the way this is rendered hegemonic in order to devise and influence the selection of institutional arrangements (see the Ensminger model) that is of interest. As older studies in this field in contexts in the global south show, natural science disciplines frequently labelled, and still label, areas inhabited by humans for centuries as "pure nature" without any human influence (see Fairhead and Leach 1996; Neumann 1998; Brockington et al. 2008; Haller and Galvin 2011; Haller 2010). They explain that it was not recognised that many so-called natural areas were in fact cultural landscape ecosystems with a distinct biodiversity that had been shaped and maintained for centuries on the basis of common property institutions (see Haller 2019a, 2019b). Based on such misinterpretations, in many part of the global south and partly also the north, common property has been transformed into state and private property and through these transformations, not only have property rights been removed from local communities - often with negative impacts - but also the capacity to adapt rules and regulations for sustainable management and the enhancement of resilience within the local group (see Haller 2010; Haller et al. 2019; Geiger et al. 2019).

In Switzerland, contrary to most regions in the global south, commoners' organisations have to a large extent remained in control of their property and thus have a higher level of bargaining power (although increasingly contested, as we will see in this book), as they enjoy the basic right of being state 
accepted co-owners of forests, pastures and agricultural land. They are able to receive state support (in the form of subsidies or direct payments), based on the notion that they are the custodians of natural resources and cultural landscapes that are not only valuable economically for agriculture or forestry but also for ecosystem and landscape services such as biodiversity, hazard protection or leisure. Nevertheless, the commoners' position is still contested: on the one hand, there is a demand for more state control over the management of "nature" to be found in the land owned by commoners; on the other hand, there is a request for more neoliberal solutions and self-responsibility. Interlinked with these two claims are the narratives about "Swissness" and the related symbolic meaning of local and "traditional" production, but also diverse views of the function and allocation of state subsidies for agriculture and forestry. Thus, many commoners' organisations find themselves between diverse interest groups, which do not necessarily recognise all the services they are providing for society. They are also challenged by the notions of common property systems being old-fashioned or socially unjust. The political ecology approach looks specifically at such contested narratives and asks who has the power to define rational and sustainable use, and which policies of good management and governance in resource management are suitable. Here we follow an approach combining New Institutionalism and Political Ecology, which also has been proposed for commons analysis in the global south (Haller 2019a). This combined New Institutional Political Ecology (NIPE) model is an extension of the model in Figure 4.2 and helps to analyse the transformation from an agrarian society to an industrial and post-industrial one, with a reduction in the value of common-pool resources related to pasture and forest areas and their products compared to the value of labour and an increased valuation of environmental or landscape services. This transformation process has led to societal change in alpine and other remote rural areas and also to a series of new state regulations and support systems that the commoners' organisations have to balance. They have to deal with actors who have greater bargaining power and can influence such transformation processes while trying to maintain common property and the governance system that is the backbone when striving for sustainability. Thus, the question has to be asked how transformation processes in actual contexts affect the vulnerability and resilience of these commoner's organisations.

\subsection{Resilience, path dependency and transformational change}

Local forms of common property organisations have managed common-pool resources in Switzerland for a long time and by doing this have significantly shaped cultural landscapes. Despite societal and environmental changes over the centuries, such systems are still widespread in Switzerland. Studying resilience can thus be a valid approach for analysis and understanding when investigating the reasons behind such developments. Resilience in our context is 
understood as the capacity of a system to absorb disturbance and reorganise while undergoing change so as to still retain essentially the same function, structure and feedback, and therefore identity (Folke 2016; based on Walker et al. 2004; Folke et al. 2010). This means that such local organisations were able to adapt and transform themselves in a way that kept their basic structures and way of acting. This, however, does not exclude transformations involving shifts in perception and meaning, social network configurations, patterns of interactions among actors including leadership and political and power relations, and associated organisational and institutional arrangements (Folke et al. 2010: 5; with reference to Folke et al. 2009; Huitema and Meijerink 2009; Smith and Stirling 2010). Such shifts and new arrangements - as will be shown were the focus of our research and the corresponding results. Congruently with Wilson (2017: 6-7) we thus consider resilience as both an outcome, especially when linked to the improved adaptive capacity of communities, and a process linked to the dynamic changes over time associated with community learning and the willingness of communities to take responsibility and control of their development pathways. The impact of these pathways cannot be overestimated. In Switzerland's agriculture, CPR mostly emerged related to forests and alpine grazing lands. Actors involved in such commoners' organisations may in some cases have a preference for individual farming, but it is extremely difficult to transform common alpine summering farms into several private ones. Conversely, recent attempts to strengthen cooperative organisations in lowland agriculture, most visible in the form of community-supported agriculture (Roque et al. 2008) or urban farming (Knapp et al. 2016), have faced obstacles and moved slowly.

Despite their ability to adapt and transform themselves, collective systems as institutional forms were always, and still are, under both external and internal pressure. This raises questions - among others - about how commoners' organisations, but also the remaining direct users, deal with the pressure for legitimacy or the potential loss of bargaining power in negotiations. It is therefore important in debates on resilience and on transformational change that there is reflection on power-driven changes and the ability of less or more powerful actors to adapt. In our research, such factors become particularly important when dealing with connections between commoners' organisations and the diverse political levels, but also when focusing on the inside, the internal corporation power relations: in a collective system, there are power asymmetries, even if they might be less than in private property systems, in which the most powerful are more able than others to shape the rules of the game. An institutional and political-ecological analysis reflects these processes and their impact on commons and their resilience. Social-ecological resilience would then mean, under a political ecology and New Institutionalism perspective, that the more powerful do not have the ability to override the interests of the other, less powerful actors and that also less powerful actors have a level of bargaining power so that their views and aspirations cannot be overridden. 


\subsection{The 'Swiss commons lab' and constitutionality: conditions for resource institution building from below}

In the context of debates on resilience and vulnerability we will reintroduce the notions of economic rationality and of bargaining power to cope with external changes. As Landolt and Haller (2015) show in their case studies in the Swiss canton of Grisons, commoners' organisations may face narratives of over- or underuse and of maladaptions, and it is not recognised that these organisations face multiple and very different local situations and challenges. At the same time, the right of communal property is guaranteed, which is different than in many other regions in the world. Consequently, Switzerland can be seen as a laboratory for the sustainable management of common-pool resources in this respect. In our case studies we will show how different strategies of local commoners' organisations are often on different scales, depending on their bargaining power vis à vis the market and the state. In order to create room for manoeuvring in economics and identity and to consolidate internally, strategies that create diversification, enhance resilience socially and economically, and reduce vulnerability are of interest. We thus focus on the economic, political and social strategies of commoners' organisations such as corporations (Korporationen) and civic communities (Bürgergemeinden, bourgeoisies, patriziati) regarding how they deal with changes of relative prizes. Furthermore, we are interested in understanding how they were able to build new institutions reflecting the old ownership of land and land-related commons while facing high costs. This refers to of Chayanov's model, but in another sense: it is not the intersection of utility and drudgery that we need to look at, but we hypothesise that the model needs to be adapted to look at the positive identity utility commoners have in still maintaining the cultural landscape under the conditions of economic drudgery, high work load and high costs, which are not all compensated by subsidies and market prices. We argue that if the financial drudgery is too high, the challenge for commoners to maintain commonly owned forests and pastures may also become too high. If the identity utility is still high at the same time, then new institution building from below is possible.

Lessons from case studies in the global south (Zambia, Mali, Bolivia and Indonesia) on how new bottom-up institutions were developed and their comparison, led to an approach called "constitutionality". This approach looks at successful bottom-up institution-building processes in which all local actors have a sense of ownership in the institution-building process for new forms of common property governance such as fisheries, pasture and forest management (see Haller 2016; Haller et al. 2018, 2019). The authors showed that the following six conditions helped to create new institutions from below: (1) local problem definition, (2) processes that mitigate power differences, (3) already existing institutional setting among local actors, (4) facilitating external agents in enabling a fair platform for discussions, (5) innovative local strategies and social learning, as well as combining old and new strategies, and last but not least, (6) acceptance of these local institutions by the state. Constitutionality 
takes place if all local actors feel included in the institution-building process and this is exactly what is often lacking: for example, women's work in the context of common property management is, as we argue, often ignored (see also Haller et al. 2019 for African cases).

The ability in different environmental and social contexts to adapt or create new institutions varies. Case studies by Landolt (2019), Head-König (2013, 2019) and Baur and Binder (2013) show differences and different abilities in being able to craft new institutional settings from the bottom up. They show that commoners' organisations are balancing with (Leerschlag) market and state and also highlight the important role of commoners' identity and their rationality. These issues are important in understanding how Switzerland - where communal tenure rights are respected - is providing a kind of a laboratory in adapting and changing institutions that have to face the above-mentioned balance. The studies conducted for our research focus on the variety of "solutions" in this 'Swiss commons lab' and the way the local bargaining power of corporations in relation to municipalities, cantons and the Swiss confederation affects these processes of institution building. We also focus on the question of how differences between and within commoners' organisations, their identity and their local knowledge, shape strategies in the 'Swiss commons lab'. Finally, we will also look at factors that increase the vulnerability and enhance the resilience of commoners' organisations in crafting new local institutions for the maintenance of cultural landscape ecosystems in Switzerland.

\section{References}

Amini, A. M., and Ramezani, M. (2008) 'Investigating the Success Factors of Poultry Growers' Cooperatives in Iran's Western Provinces', World Applied Sciences Journal, vol 5, no 1, pp 81-87.

Barton, D., Boland, M., Chaddad, F., and Eversull, E. (2011) 'Current Challenges in Financing Agricultural Cooperatives', Choices, vol 26, no 3, pp 121-134.

Baur, I., and Binder, C. R. (2013) 'Adapting to Socioeconomic Developments by Changing Rules in the Governance of Common Property Pastures in the Swiss Alps', Ecology and Society, vol 18, no 4. http://www.ecologyandsociety.org/vol18/iss4/art60/.

Baur, I., Liechti K., and Binder C. R. (2014) 'Why Do Individuals Behave Differently in Commons Dilemmas? The Case of Alpine Farmers Using Common Property Pastures in Grindelwald, Switzerland', International Journal of the Commons, vol 8, no 2, pp 657-685.

Bergen, V., Löwenstein, W., Olschewski, R. (2013) Forstökonomie. Volkswirtschaftliche Ansätze für eine vernünftige Umwelt- und Landnutzung. München: Vahlen.

Brockington, D., Duffy, R., and Igoe, J. (2008) Nature Unbound: The Past, Present and Future of Protected Areas. London: Earthscan.

Cancian, F. (1989) 'Economic Behaviour in Peasant Communities', in Plattner, St. (ed.), Economic Anthropology (pp 1-20). Stanford: Stanford University Press.

Capaldo, J. (2007) On the Marxian Law of the Falling Rate of Profit and Marx-Biased Technical Change. Toramo: University of Toramo.

Cleaver, F. (2003) 'Reinventing Institutions: Bricolage and the Social Embeddedness of Natural Resource Management', in Benjaminsen, T. A., and Lund, C. (eds), Securing Land Rights in Africa (pp 11-30). London/Portland: Frank Cass. 
De Sardan, O. (2013) 'Embeddedness and Informal Norms: Institutionalisms and Anthropology', Critique of Anthropology, vol 33, no 3, pp 280-299.

Diaw, M. C. (2005) 'Modern Economic Theory and the Challenge of Embedded Tenure Institutions: African Attempts to Reform Local Forest Policies', in Kant, S., and Berry, R. A. (eds), Institutions, Sustainability, and Natural Resources (pp 43-81). Heidelberg: Springer.

Dietz, T., Ostrom, E., and Stern, P. C. (2003) 'The Struggle to Govern the Commons', Science, vol 302, pp 1907-1912.

Ensminger, J. (1992) Making a Market. The Institutional Transformation of an African Society. Cambridge: Cambridge University Press.

Fairhead, J., and Leach, M. (1996) Misreading the African Landscape: Society and Ecology in a Forest-Savannah Mosaic. Cambridge: Cambridge University Press.

Folke, C. (2016) 'Resilience (Republished)', Ecology and Society, vol 21 no 4, p 44.

Folke, C., Carpenter, S. R., Walker, B., Scheffer, M., Chapin, T., and Rockström, J. (2010) 'Resilience Thinking: Integrating Resilience, Adaptability and Transformability', Ecology and Society, vol 15, no 4. http://www.ecologyandsociety.org/vol15/iss4/art20/

Folke, C., Chapin III, F. S., and Olsson, P. (2009) 'Transformations in Ecosystem Stewardship', in Folke, C., Kofinas, G. P., and Chapin III, F. S. (eds), Principles of Ecosystem Stewardship: Resilience-Based Natural Resource Management in a Changing World (pp 103-125). New York: Springer.

Giger, M., Nolte, K, Anssew, W, Breu, T., Messerli, P., Oberlack, C., and Haller, T. (2019) 'Impacts of Large-Scale Land Acquisitions on Common-Pool Resources: Evidence from the Land Matrix', in Haller, T., Breu, T., de Moor, T., Rohr, C., and Znoj, H. (eds), The Commons in a Glocal World: Global Connections and Local Responses (pp 257-279). London: Routledge.

Haller, T. (2001) Leere Speicher, erodierte Felder und das Bier der Frauen. Berlin: Reimer Verlag.

Haller, T. (2007) Understanding Institutions and Their Links to Resource Management from the Perspective of New Institutionalism. NCCR North-South Dialogue 2. Bern: Switzerland, NCCR North-South.

Haller, T. (ed.). (2010) Disputing the Floodplains: Institutional Change and the Politics of Resource Management in African Floodplains. Leiden: Brill.

Haller, T. (2013) The Contested Floodplain. Institutional Change of the Commons in the Kafue Flats, Zambia. Lanham: Lexington Books.

Haller, T. (2016) 'Managing the Commons with Floods: The Role of Institutions and Power Relations for Water Governance and Food Resilience in African Floodplains', in Ostegard, T. (ed.), Water and Food - Africa in a Global Context (pp 369-397). Uppsala: Nordic African Institute. I.B. Tauris.

Haller, T. (2019a) 'Towards a New Institutional Political Ecology: How to Marry External Effects, Institutional Change and the Role of Power and Ideology in Commons Studies', in Haller, T., Breu, T., de Moor, T., Rohr, C., and Znoj, H. (eds), The Commons in a Glocal World: Global Connections and Local Responses (pp 90-120). London: Routledge.

Haller, T. (2019b) 'The Different Meanings of Land in the Age of Neoliberalism: Theoretical Reflections on Commons and Resilience Grabbing from a Social Anthropological Perspective', Land, vol 8, no 7. doi: 10.3390/land8070104

Haller, T., Adams, T., Gmür, D., Käser, F., Lanz, K., Marfurt, F., Ryser, S., Schubiger, E., Sury, A., and Gerber, J. D. (2019) 'Large Scale Land Acquisition as Commons Grabbing: A Comparative Study on Cases from Africa', in Lozny, L., and McGivern, T. (eds), Global Perspectives on Long Term Community Resource Management (pp 125-164). Berlin, New York: Springer. 
Haller, T., Belsky, J. M., and Rist, S. (2018) 'The Constitutionality Approach: Conditions, Opportunities, and Challenges for Bottom-Up Institution Building', Human Ecology, vol 46, no 1, pp 1-2.

Haller, T., Breu, T., de Moor, T., Rohr, C., and Znoj, H. (eds.). (2019) The Commons in a Glocal World: Global Connections and Local Responses. London: Routledge.

Haller, T., and Galvin, M. (2011) 'Challenges for Participatory Conservation in Times of Global Change: Lessons from a Comparative Analysis and New Developments', in Wiesmann, U., and Hurni, H. (eds), Research for Sustainable Development: Foundations, Experiences, and Perspectives (pp 467-503). Perspectives of the Swiss National Centre of Competence in Research (NCCR) North-South, University of Bern, Vol. 6. Geographica Bernensia. Bern: University of Bern.

Head-König, A. L. (2013) 'Property Rights in Switzerland during the Eighteenth and Nineteenth Centuries. A Possible Explanation for Different Types of Economic Change?', in Béaur, G. et al. (eds), Property Rights, Land Markets, and Economic Growth in the European Countryside (Thirteenth-Twentieth Centuries) (pp 515-535). London: Turnhout.

Head-König, A. L. (2019) 'The Commons in Highland and Lowland Switzerland Over Time: Transformations in Their Organisation and Survival Strategies (Seventeenth to Twentieth Century)', in Haller, T. Breu, T., de Moor, T. Rohr, C., and Znoj, H. (eds), The Commons in a Glocal World: Global Connections and Local Responses (pp 156-172). London: Routledge.

Henriksen, I., Hviid, M., and Sharp, P. (2012) 'Law and Peace: Contracts and the Success of the Danish Dairy Cooperatives', The Journal of Economic History, vol 72, no 1, pp 197-224.

Hertz, N. (2011) 'The End of Gucci Capitalism', in C. Pitelis, J. Keenan, and V. Pryce (eds), Green Business, Green Values, and Sustainability (pp 100-120). London: Routledge.

Huitema, D., and Maijerink, S. (eds). (2009) Water Policy Entrepreneurs: A Research Companion to Water Transitions around the Globe. Cheltenham, Gloucestershire, UK: Edward Elgar.

Janssen, M. A., and Ostrom, E. (2006) 'Adoption of a New Regulation for the Governance of Common Pool Resources by a Heterogeneous Population', in Baland, J. M. et al. (eds), Inequality, Cooperation, and Environmental Sustainability (pp 60-96). Princeton: Princeton University Press.

Katzenstein, P.J. (2009) 'Mid-Atlantic: Sitting on the knife's sharp edge', Review of International Political Economy, vol 16, no 1, pp 122-135.

Kerbely, B. (1984) 'Chayanov and the Theory of Peasantry as a Specific Type of Economy', in Shanin, T. (ed.), Peasant and Peasant Societies (pp 142-150). Middlesex: Penguin Books.

Knapp, L., Veen, E., Renting, H., Viskerke, J. S. C., and Groot, J. C. J. (2016) 'Vulnerability Analysis of Urban Agriculture Projects: A Case Study of Community and Entrepreneurial Gardens in the Netherlands and Switzerland', Urban Agriculture \& Regional Food Systems, vol 1, no 1, pp 1-13.

Landolt, G. (2019) 'Swiss Alpine Pastures as Common Property: A Success Story of Bottom-Up Institution-Building in Sumvitg, Canton Grisons, Switzerland', in Haller, T. Breu, T., de Moor, T. Rohr, C., and Znoj, H. (eds), The Commons in a Glocal World: Global Connections and Local Responses (pp 233-254). London: Routledge.

Landolt, G., and Haller, T. (2015) 'Alpine Common Property Institutions under Change: Conditions for Successful and Unsuccessful Collective Action by Alpine Farmers in the Canton of Grisons, Switzerland', Human Organization, vol 74, no1, pp 100-111.

Lips, M., Pulfer, I., and Messer, M. (2008) Sind Betriebsgemeinschaften wirtschaftlicher als Einzelbetriebe? In Th. Glebe: Agrar- und Ernährungswirtschaft im Umbruch. Münster: Landwirtschaftsverlag. 
Mann, S. (2011) 'Merit Sectors', in Mann, S. (ed.), Sectors Matter - Exploring Mesoeconomics (pp 41-51). Berlin: Reimer.

Netting, R. (1981) Balancing on an Alp: Ecological Change and Continuity in a Swiss Mountain Community. Cambridge: Cambridge University Press.

Neumann, R. P. (1998) Imposing Wilderness. Struggles over Livelihood and Nature Preservation in Africa. Berkley: University of California Press.

Ortu, C. (2008) 'The Denial of Class Struggle by British Governments in Their Anti-Union Discourse (1978-2007)', Critical Discourse Studies, vol 5, no 4, pp 289-301.

Ostrom, E. (1990) Governing the Commons. The Evolution of Institutions for Collective Action. Cambridge: Cambridge University Press.

Ostrom, E. (2005) Understanding Institutional Diversity. Princeton: Princeton University Press.

Poggie, J. J., Pollnac, R. B., and Fierro, M. (1988) 'Factors Influencing the Success of Fishermen's Cooperatives in Ecuador', Marine Resource Economics, vol 5, no 3, pp 199-211.

Powell, W. W. (1990) ‘Neither Market nor Hierarchy', in Godwyn, M., and Hoffer Gittell, J. (eds), Sociology of Organizations: Structures and Relationships (pp 30-40). New York: SAGE.

Roque, O., Thévenot-Mottet, E., Bourdin, D., and Barjolle, D. (2008) Innovations in Direct Marketing in Agriculture in Switzerland. Lausanne, Switzerland: Agridea.

Schweizer, R., Rodewald, R., Liechti, K., and Knoepfel, P. (2014) Des Systèmes d'irrigation alpins entre gouvernance communautaire et étatique - Alpine Bewässerungssysteme zwischen Genossenschaft und Staat. Écologie \& Société / Ökologie und Gesellschaft 24. Zürich/ Chur: Rüegger.

Shanin, T. (1973/4) 'The Nature and Logic of Peasant Economy', The Journal of Peasant Studies, vols 1 and 2, pp 63-80, 187-206.

Smith, A., and Stirling, A. (2010) 'The Politics of Social-Ecological Resilience and Sustainable Sociotechnical Transitions', Ecology and Society, vol 15, no 1. http://www .ecologyandsociety.org/vol15/iss1/art11/

Theuvsen, L., and Franz, A. (2007) 'The Role and Success Factors of Livestock Trading Cooperatives: Lessons from German Pork Production', International Food and Agribusiness Management Review, vol 10, no 3, pp 90-112.

Tiefenbach, M. (2013) Alpkorporationen. Traditionelle Institutionen nachhaltiger Landschaftsentwicklung. Das Beispiel der Bergschaften Grindelwalds im Kontext aktueller gesellschaftlicher Herausforderungen. Grindelwald, Switzerland: Suter Druck AG.

Walker, B., Holling, C. S., Carpenter, S. R., and Kinzig, A. (2004) 'Resilience, Adaptability and Transformability in Social-Ecological Systems', Ecology and Society, vol 9, no 2. https ://www.ecologyandsociety.org/vol9/iss2/art5/

Williamson, O. E. (1987) 'Transaction cost economics: The comparative contracting perspective', Journal of Economic Behaviour and Organization, vol 8, no 4, pp 617-625.

Wilson, G. A. (2017) 'Resilience and Human Geography', in Richardson, D., Castree, N., Goodchild, M. F., Kobayashi, A., Liu, W., and Marston, R. A. (eds), The International Encyclopedia of Geography (pp 5887-5896). London: John Wiley \& Sons.

Wolz, A., Kopsidis, M., and Reinsberg, K. (2009) 'The Transformation of Agricultural Production Cooperatives in East Germany and Their Future', Journal of Rural Cooperation, vol 37, no 1, pp 5-19.

Zarafshani, K., Rostamitabar, F., Hosseininia, G. H., Akbari, M., and Azadi, H. (2010) 'Are Agricultural Production Cooperatives Successful? A Case Study in Western Iran', American-Eurasian Journal of Agricultural and Environmental Sciences, vol 8, no 4, pp 482-486 
$\fallingdotseq$ Taylor \& Francis Taylor \& Francis Group http://taylorandfrancis.com 
Part II

Case studies 
$\fallingdotseq$ Taylor \& Francis Taylor \& Francis Group http://taylorandfrancis.com 


\title{
5 Scopes and challenges of a huge corporation over time
}

\author{
The case of the Korporation Uri (Canton Uri)
}

\author{
Rahel Wunderli
}

\subsection{Introduction}

In terms of its territory, the Korporation Uri (Corporation of Uri) is one of the biggest, if not the biggest corporation in Switzerland. Its property is located in the northern part of the canton of Uri, between the bottleneck gorge of Schöllenen and Lake Lucerne. Figure 5.1 shows the landed property of the Corporation in the northern, lower - as it is lower in geographical terms - part of the canton. Together with the Korporation Ursern (Corporation of Ursern), the second and smaller corporation of the canton (its property is located in the high valley of Ursern, the non-hachured area in Figure 5.1), the Korporation Uri owns approximately 70 per cent of the canton's territory and is thus the biggest land owner. This size is of historical origin.

In this chapter, following some introductory remarks (Sections 5.1-5.4), the history of the Corporation is told in four phases in Section 5.5: the development of a commons cooperative consisting of several villages in the Middle Ages; its development into a leading political organisation in the course of the Early Modern Period; its transformation from a state entity into a corporation under public law in the nineteenth century; and its position within the political structure of the twentieth and twenty-first centuries. The situation in the twentieth to the twenty-first centuries is described in most detail. Each of these four phases is structured into a first part focusing on the organisation and a second part focusing on its main property, forests and pastures.

Such emphasis on two fields - organisation and resources - is connected with the object of study itself, that is, an association of persons whose development, structure and political legitimacy are based on the fact that it organises and supervises the use of natural resources as collective property. Thus, organisation and resources are closely interrelated. Without property there would be no corporation and without any regulating authority there would be no cultivated landscape as we find it today. In a way, the organisation has inscribed itself into the terrain. 


\section{Rahel Wunderli}

\subsection{Geographic and physiographic framework conditions}

The canton of Uri is located in central Switzerland and is - as becomes obvious from the historical aerial photograph (Figure 5.2) - undeniably a mountain canton. Indeed, 56 per cent of its territory is considered to be fallow land (see the extension of rock/scree fields and glaciers in Figure 5.1) and relative to the rest of Switzerland its population density is very low. The lower part of the canton comprises the main valley, which in the southern part, called oberes Reusstal after the River Reuss, is still very narrow but becomes much wider farther north. To the east and the west, several side valleys branch out from this main valley, most of which are inhabited throughout the year. The mountain slopes are generally steep and mostly covered with wood. Most of the villages are in the valley bottoms, below the protective forest. In some valleys, dispersed settlements spread out as far as to the upper parts of the slopes. The main site is Altdorf which, together with its neighbouring municipalities in the northern part, called unteres Reusstal or Urner Talboden, constitutes the canton's key settlement area.



Figure 5.1 Landed property of the Korporation Uri- overview (Land cover). Map compilation and design by Sarah Baumgartner, University of Bern; geodata source: LISAG AG, Altdorf; hillshade: Relief PK 200, reproduced with permission of swisstopo (BA20043). 


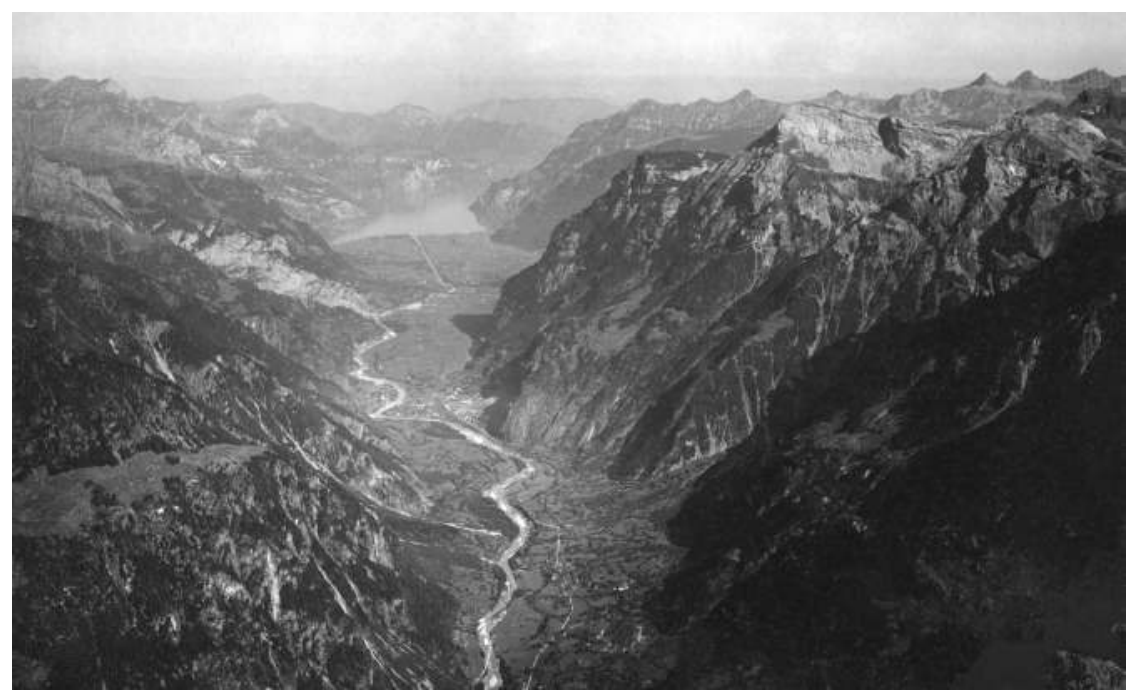

Figure 5.2 Looking from south to north, the undated aerial photograph shows the part named unteres Reusstal or Urner Talboden with the Reuss estuary into Lake Lucerne - the canton's most densely settled area - as well as the wide mountain areas with their many narrow valleys and steep slopes. Source: Staatsarchiv Uri. Photographer unknown.

Uri is internationally known as a transit region, the Gotthard Pass on the border with the canton of Ticino representing one of the most significant North-South transits in Europe today and having been of utmost importance for the economic development of the region.

\subsection{Facts and figures on the Korporation Uri today ${ }^{1}$}

The quantitative facts in the following tables and the explanations regarding the current structure of the Corporation provide a first impression of its size and complexity.

The categories marked with ${ }^{*}$ can be found in Figure 5.3.

Landed property of the Corporation

\begin{tabular}{|l|l|}
\hline Total area (including fallow lands) & $74,400 \mathrm{ha}$ \\
\hline Area under cultivation (cultivated all through the year, leased) & $341 \mathrm{ha}$ \\
\hline Alpine area owned by the Corporation & $24,893 \mathrm{ha}$ \\
\hline Forest area owned by the Corporation & $16,174 \mathrm{ha}$ \\
\hline
\end{tabular}

Alpine and forest property owned by others (mostly private owners, canton) in the lower part of the canton

\begin{tabular}{|l|l|}
\hline Alpine area owned by others (= private alps) & 2,154 ha \\
\hline $\begin{array}{l}\text { Forest area owned by others (= private, cantonal and federal } \\
\text { forests) }\end{array}$ & 3,357 ha \\
\hline
\end{tabular}






Figure 5.3 Landed property of the Korporation Uri - resources. See Section 5.3. Listed are the categories marked with ${ }^{\star}$. Map compilation and design by Sarah Baumgartner, University of Bern; geodata source: LISAG AG, Altdorf; hillshade: Relief PK 200, reproduced with permission of swisstopo (BA20043).

\begin{tabular}{l}
\hline Alps \\
\begin{tabular}{|l|l|}
\hline $\begin{array}{l}\text { Share of unpasturable area of Corporation alps (too steep or } \\
\text { too rocky) }\end{array}$ & $18 \%(4,427 \mathrm{ha})$ \\
\hline $\begin{array}{l}\text { Share of unpasturable area of private alps (too steep or too } \\
\text { rocky) }\end{array}$ & $11 \%(239 \mathrm{ha})$ \\
\hline Number of summering farms ${ }^{2}$ on Corporation alps & 205 \\
\hline Number of summering farms on private alps & 49 \\
\hline Summered livestock on Corporation alps (2019) & \\
\hline - Cows, cattle, calves & 6,722 \\
\hline - Sheep & 8,039 \\
\hline - Goats & 1,288 \\
\hline
\end{tabular}
\end{tabular}

Other property of the Corporation

\begin{tabular}{|l|l|}
\hline Waters (number) & 86 \\
\hline Real estate & \\
\hline - Multiple dwellings & 5 with a total of 49 flats \\
\hline - Single-family houses & 1 \\
\hline
\end{tabular}




\begin{tabular}{|l|l|}
\hline - Administrative buildings & $\begin{array}{l}1 \text { (accommodating the } \\
\text { Corporation's office, } \\
1 \text { doctor's surgery and } \\
1 \text { flat) }\end{array}$ \\
\hline - Alpine hut & 1 on Ruosalp \\
\hline - Kulturkloster (monastery) Altdorf & \\
\hline - Stollenanlage (mine) Ripshausen & \\
\hline $\begin{array}{l}\text { Agricultural properties with residential and economic buildings } \\
\text { (the latter leased according to planning and building laws) }\end{array}$ & 8 \\
\hline \begin{tabular}{l} 
Budget of the Corporation \\
\hline Expenses, accounting year 2019
\end{tabular} \\
\hline Revenues, accounting year 2019 & $7,535,074 \mathrm{CHF}$ \\
\hline Balance sheet total, accounting year 2019 & $7,747,814 \mathrm{CHF}$ \\
\hline Equity capital, accounting year 2019 & $54,762,861 \mathrm{CHF}$ \\
\hline
\end{tabular}

Licensing and fees of the Corporation

\begin{tabular}{|l|l|}
\hline $\begin{array}{l}\text { Licences for hydro power }>1,000 \mathrm{~kW} \text { (partly in cooperation } \\
\text { with other licensors) }\end{array}$ & 7 \\
\hline Licences for hydro power $<1,000 \mathrm{~kW}$ & 6 \\
\hline $\begin{array}{l}\text { Shares of cantonal hydropower licences (according to the } \\
\text { SNEE contract) }\end{array}$ & 3 \\
\hline $\begin{array}{l}\text { One-time fee for hydropower }<1,000 \mathrm{~kW} \text { power }(=\text { midget } \\
\text { hydropower station) }\end{array}$ & 15 \\
\hline Quarrying and dump licences $^{7 *}$ & 7 \\
\hline
\end{tabular}

Corporation citizens and users of Corporation alps

\begin{tabular}{|l|l|}
\hline Corporation citizens (effective date 3 April 2020) & 20,908 \\
\hline $\begin{array}{l}\text { Number of inhabitants in the lower part of the canton } \\
\text { (effective date 31 December 2018) }\end{array}$ & 34,704 \\
\hline Number of persons paying grazing fees ${ }^{8}$ in 2019 & 213 \\
\hline
\end{tabular}

Organisational structure and boards

- The territory of the Corporation is structured into 17 Korporationsbürgergemeinden (communities of corporation of citizens). In each of the 17 municipalities there is one Korporationsbürgergemeinde of the same name. They administer and cultivate those Corporation forests which are on their territories. For this purpose, they run their own forestries and some also exploit their own cattle alp, the so-called Rinderhirtenen. The owner of theses alps is the Corporation.

- Engerer Rat (executive board): nine members, consisting of the corporation president, the vice president and the Verwalter (administrator, head of the Corporation Chancellery) as well as six Allmendaufseher (supervisors, in charge of the local control of the Corporation's property). Meets every two weeks.

- Korporationsrat (legislative board): 32 members, elected by the 17 Korporationsbürgergemeinden. One seat on the Korporationsrat is available for every 800 citizens of a Korporationsbürgergemeinde. Each of them is guaranteed one seat. Meets five times a year.

- Korporationsgemeinde (assembly of those corporation citizens who are entitled to vote. Makes final decisions about new laws and amendments, elects the president, the vice president and the Verwalter): entitled to vote are those corporation citizens older than 18 and living in the canton. Meets every two years.

- Administration and bookkeeping: currently eight people with a total of 670 per cent by position (including one apprentice). 
As is thus obvious, today the Korporation Uri is a corporation with a large amount of property, is active in several different business sectors, is provided with a considerable budget and has a noteworthy number of citizens, broadly organised boards and a decentralised structure.

\subsection{Remarks on the state of research}

The Korporation Uri runs a densely stocked, professionally organised archive in Altdorf which is highly accessible for researchers and documents the Corporation's development since 1888, when it was separated from the canton's body of authorities as an autonomous corporation under public law. This new position within the political structure initiated a number of legal studies discussing the constitutional position of the Corporation (Huber 1911, Nager 1926, Bigger 1949, Weber 1952, Arnold 1990). Furthermore, on the occasion of its one hundred and twenty-fifth anniversary, a book was published, which covers the prehistory of the organisation, collects the facts of its development after 1888 and provides a number of starting points for an analysis of its various political-social functions in the twentieth to the twenty-first centuries (Stadler-Planzer et al. 2013). The historiography on Uri during this period of time is still comparably incomplete, although it has gathered momentum in recent years. In the context of our project, several interviews have been conducted with representatives of the Corporation as well as with other actors involved in cultivating the local forests and alpine pastures. In addition to the written sources and the literature, these interviews are included in the section headed 'The Korporation Uri as an element of the canton's political structure in the twentieth and twenty-first centuries'.

Concerning the Middle Ages and the Early Modern Period, there exist a great number of historical studies relevant for the topic discussed here. Uri (together with its neighbouring regions of Schwyz and Unterwalden) ${ }^{9}$ formed the first alliance of the Eidgenossenschaft from which later the Swiss Confederation developed. As the founding myth became very significant for the modern national state, so has the historiography on central Switzerland dealt intensively and, according to the trends of exploiting history for political purposes, controversially with this period of time (Marchal 1990). Questions of interpreting ways of organisation have received particular attention.

\subsection{The history of the Corporation and its forests and pastures}

The following elaborations basically refer to the northern part of the canton of Uri and thus to the region where the Korporation Uri has its property (see Sections 5.1 and 5.2 and Figure 5.1). Until 1798 the political name of this region was Land Uri (country of Uri). In the course of the organisational restructuring of the Helvetic Republic this was changed to Bezirk Uri (district 
of Uri). The Bezirk Uri was abandoned as part of the 1888 revision of the canton's constitution. Today, in everyday language one still speaks of the "lower part of the Canton", but the region is no longer an official administrative unit.

Ursern in the southern part of the canton is in principle not subject to the following elaborations. The history of this high valley shows some marked differences from that of the Land Uri. However, in this area a corporation (Korporation Ursern) has its seat, which is of significance for the history and the present situation of the Korporation Uri. For that reason, the region will be included in the account if necessary.

\section{The development of a collective administration of resources in the Middle Ages}

If we ask the question about the historical beginnings of the collective exploitation of resources in the region of contemporary Uri, the controversial historiography on central Switzerland in the Middle Ages mentioned in Section 5.4 comes into the picture. It raises some important methodological issues. Some authors emphasise that in this region there developed a political entity with a stable inner order covering several villages already at an early stage: the Land Uri. This political organisation, it is said, purposefully pushed away the local nobility and the monasteries as feudal lords, democratised its own structures and procedures, regulated the exploitation of the natural resources and was thus able to survive as an autonomous political actor until the end of the ancien régime. According to this reading, the former commoners' organisation still survives in today's Korporation Uri (Stadler-Planzer 1993). Other authors do not emphasise the local aspirations for self-regulation but rather the influence of the feudal actors (nobility and monasteries) as well as economic and political developments outside the region (e.g. North-South transit traffic, the rise of cities) on the evolution of the local political organisation. They interpret the unity formulated in the written evidence as a power strategy of local elites, and highlight the inner heterogeneity and instability of this political union (Sablonier 1990, 2008).

From a longue durée perspective it is not easy, but nevertheless it is important, to take both positions into consideration. It is not easy because the question of how they must be weighed considerably increases the demands on source interpretation. It is important because the Corporation's current shape can only be understood as the historical product of both aspects: on the one hand, as an entity that owes its great influence to path dependency, more precisely to the centuries-old regulation of a cross-regional organisation, which influenced society in a number of ways; on the other hand, as an entity that is crucially characterised by its inner contradictions and high density of conflicts and that owes its existence, among other factors, to (favourable) historical conditions created by other political actors. The following account attempts to relate the two perspectives. 


\section{Feudalism and communalisation}

In the medieval sources we find formulations such as "nos inhabitants Uroniam" (955), "homines universi vallis Uranie" (1273) and "die landluit gemeinlich ze Ure" (1348-1358). All of them imply a territorially defined association of persons. However, the system of rule in the context of which these names were used differed in each case. Whereas in the tenth century the Zurich Abtei Fraumünster (Abbey of Fraumünster) and the noble von Rapperswil family owned comparably large seigneuries in Uri, by the end of the thirteenth century a change of rule was taking place, in the course of which previously influential noble families were replaced by the Habsburg's sovereignty over the region and the growing urban communities in the surrounding region (Zurich, Bern and the central places in Lombardy). Furthermore, at that time, several monasteries, in particular the Kloster Wettingen, extended their property in Uri, organised it more strictly, participated in land development and supported intensified animal husbandry on the so-called Schweighöfe (farms) they had founded.

However, during the entire Middle Ages the extent to which the feudal order pushed through in central Switzerland and other mountain regions was clearly less than in the lower areas (called Mittelland today). The seigneuries of this mountain region were administered by so-called Meiers (stewards). Based on their positions, they achieved considerable political and economic influence and over time became the local elite, together with families running the Schweighöfe of the monasteries. In the fourteenth and fifteenth centuries they occupied the position of Landamman, the highest position in the establishing Land Uri.

Against the background of this changing political situation, it remains an open question how far the above-mentioned (self-given) names from the medieval sources referred to one and the same collective. Due to the political context, it is possible that these were formations with a commons-cooperative background or entities initiated by feudal lords.

It is conspicuous that from the twelfth century, Landleute von Uri (citizens of the Land Uri) frequently appeared in the context of border disputes with associations of persons and organisations in neighbouring regions: with the Land Glarus (country of Glarus) and the Land Schwyz (country of Schwyz) in the northeast and the north and with the monastery of Engelberg in the northwest (Brändli 1986). These disputes were mostly about alpine pastures in pass regions (Stadler-Planzer 1993). In all three cases, finally Uri, after centurieslong struggles, extended its territory at the expense of its opponents.

\section{Ways of organisation}

From the mid-fourteenth century there is evidence of a multiple, crossregional political organisation in Uri. The biggest board was the Landrat of 60 seats. Six members each of this council (the Ratsherren) were elected 
by one of the ten Genossamen. The Genossamen were election and tax districts into which the region dominated by the Land Uri was structured. The Landrat was headed by the superior officials - the Vorgesetzte Herren - and presided over by the Landamman. Furthermore, the Landsgemeinde (assembly of male inhabitants of the Land older than 15) counted among the legislative authorities. Several courts of law had juridical tasks and several public officials had administrative tasks. Parallel to this superior organisation, the written sources reveal different local organisations: Dorfschaften (village communities), Alpgenossenschaften (alpine cooperations), Nachbarschaftsverbände (neighbourhood associations) and Talschaften (valley communities) (Sablonier 1990).

Deeds from this time provide evidence of the great significance of the exploitation of resources for all these political entities. A general interest in gaining control of areas that could be exploited becomes obvious (Sablonier 1990). The above-mentioned agreements on borders in alpine regions were confirmed by the Land Uri, ${ }^{10}$ legal verdicts concerning utilisation rights for alpine pastures and forests were recorded for individual village communities ${ }^{11}$ and the division of forests into different utilisation zones was published. ${ }^{12}$ In 1363, pasture regulations for Ursern were written down. ${ }^{13}$ It is conspicuous in these cases that each local regulation was confirmed by the Landsgemeinde (Stadler-Planzer 1993), with the exception of those of the valley community of Ursern, which in those days still belonged in the sphere of influence of the monastery of Disentis (in the present-day canton of Grisons). Thus, it seems as if already at an early stage, the Land Uri established its responsibility for issues of the cross-village regulation of resources.

\section{Border disputes and their functions}

The function of natural resources for the ways in which the political actors understood themselves becomes particularly obvious when one considers the border disputes that took place in alpine regions. That these so-called Marchenstreite sometimes lasted over decades and even centuries (Landolt 2008b) must be considered an advantage for the consolidation of the organisations involved, because it required constant self-assurance (Brändli 1986). In the case of Uri, for example, the Riemenstaldental, a valley on the border to Schwyz, was such a region. Indeed, as late as 1973 (!), a study on the "legal-systematic position and valid content of exploitation rights agreed by the ancient places of Uri and Schwyz in the context of the border contract of 1350 " was presented (Bloetzer 1973).

Many such conflicts were characterised by episodes of violence. During the dispute between Uri and the monastery of Engelberg, for example, cases of cattle rustling and animal slaughter took place (Brändli 1986). Such episodes illustrate the important function of the alpine regions for the rural economy of central Switzerland. They were closely connected to the dynamic development of agriculture towards market-oriented livestock production, which 


\section{Rahel Wunderli}

will be explained in greater detail below. However, the use of violence in the context of disputes over border regions must also be interpreted as politicalsymbolic acts which, purposefully used and well dosed, could improve the reputation and increase the influence of a group. In many cases, such incidents influenced the local jurisdiction and resulted in the further development of legal procedures (Brändli 1986; Sablonier 1990). Nevertheless, it is also important to emphasise that in each case, these conflicts were only local and did not extend into warlike troubles.

Woodlands and pastures as elements of the economic structures and dynamics of the Middle Ages

\section{CHANGES IN AGRICULTURE}

The establishment of territorial political entities was closely interwoven with an economic development that in central Switzerland started in the course of the Late Middle Ages and continued until far into the Early Modern Period. Specifically, between the thirteenth and sixteenth centuries a restructuring of agriculture took place, altering it from being oriented towards self-subsistence and autarchy to an export-oriented means of cultivation and production (Glauser 1988; Sablonier 1990). The most important causes of this radical development were the growth of the cities in the vicinity of the Alps (in the course of which the northern Italian cities became the main sales market for central Switzerland), the opening of the route across the Gotthard from the thirteenth century as well as comparably favourable natural space conditions for pastoral agriculture.

In Uri, grain cultivation completely disappeared at that time; only vegetables continued to be grown in small gardens (Bielmann 1972). Cattle husbandry was extended and heavy livestock became more important than the previously dominating sheep and goats. This long-term change, which still characterises the region today, increased the demand for pastures, resulted in an expansion of cultivated lands on the alpine level and consequently led to the border disputes described above. It is obvious that the growing trend of fixing regulations in writing must be read as an attempt to defuse the conflicts that accompanied this change.

The conflicts over alpine pastures demonstrate that the economic shift supported the political consolidation of the Land Uri. What, however, were its inside effects, that is, how did it affect economic and social differences between people? The existing sources allow for identifying two trends. First, cattle trade and the transport of goods provided the rural population with different seasonal opportunities of gainful work (Marty 1951). Broad social classes participated in this economic branch and thus extended their economic basis. Second, it must be assumed that the change increased the discrepancy between owners of heavy and small livestock, as livestock husbandry was increasingly dominated by heavy livestock (Glauser 1988; Sablonier 1990). Furthermore, farmers owning 
considerable private property, animals and capital now had better opportunities to become rich in the risky cattle trade than those with little property (Marty 1951). Accordingly, the local political leading class, which would be reinforced in the course of the centuries to come, consisted mostly of farmers who were highly involved in this kind of trade (Brändli 1986; Kälin 1991).

\section{WAYS OF EXPLOITING WOODLANDS}

As concerns forests, it must first be stated that as suppliers of wood as a raw material (which was crucial for agrarian societies) ${ }^{14}$ and as places that could be utilised in a number of other ways (e.g. pastoral agriculture and gathering economy), they were immediately affected by diverse developments of the population (Stuber/Bürgi 2011). Accordingly, regulating their utilisation belonged to the core business of the political authorities. This can be clearly seen from the above-mentioned documents.

The agricultural change from self-subsistence to export economy affected the woodlands of the Land Uri first inasmuch as they were interlinked with pastures. Accordingly, in the context of disputes about alpine pastures - such as the conflict between Uri and Schwyz over the Riemenstaldental (Landolt 2008a) - in each case a question was also raised about how and by whom the woodlands in the concerned areas could be exploited. After all, firewood and timber were crucial raw materials for alpine farming and in particular for the production of cheese. For woodland regulations, on the other hand, regulating the wood pastures was always an important element. The great significance of forests as suppliers of wood, as pastures and as stores of other resources such as plant litter, bark and so forth finds expression in the Bannordnung (banning order) of Flüelen of 1382, which probably still served as a legal foundation in the eighteenth century. Furthermore, through this document a complicated property situation becomes obvious, as the individual exploitation rights of inhabitants and the collective rights of the entire village community were negotiated within it (Sablonier 1990).

Apart from agricultural interests in woodlands and the demand for settlements (timber and firewood), several other trades also reached back to woodlands as a resource, not least charcoal burning, lime burning, resin burning and iron processing. In Uri, in a number of places there is evidence of lime burning by way of field names and the remains of sites, some of which were still in operation in the late nineteenth century. Furthermore, charcoal burning was very common. Due to its large consumption of wood, it was limited at an early stage, but in individual places it continued to be practised in the late nineteenth century. The mining and smelting of ores were practised only punctually, although still in 1916 there existed a regulation according to which any Corporation member was entitled to mine ore in the commons. Resin burning was mainly undertaken by the poorer classes. They collected the wood of cut trees and boiled it out to make suds and soap (Oechslin 1927). 


\section{The utilisation of the commons in the context of the political system of the Land Uri in the Early Modern Period}

The complex political situation described for the Middle Ages - different local units (parishes, villages and cooperatives) with a certain degree of autonomy and the Land Uri as an influential, superior authority regulating the utilisation of the commons - would remain basically the same in the centuries to come. As innovations in the Early Modern Period, the beginning of putting legal decrees into writing and the introduction of additional councils at the level of the Land must be mentioned. As a result of these extensions, the political system became even more complex. At the same time, in the course of the Early Modern Period the Vorsitzende Herren (Presiding Gentlemen), who had been presiding over the Landrat as the superior authority since the late fourteenth century, became ever more closed off as a small, exclusive social group and attained considerable power. The political system developed into a real oligarchy dominated by a few families of magistrates. For some time, the symbolic nature of the Landsgemeinde was stronger than its political function (Kälin 1991).

\section{Expansion}

As early as the Late Middle Ages the Land Uri sought to gain control of the Gotthard route as far as to Lombardy. By way of contracts and acts of war, sometimes on its own but mostly in cooperation with other estates of the alliance Eidgenossenschaft, it expanded south in the course of the fifteenth and sixteenth centuries. Furthermore, Uri participated in governing the so-called Gemeinen Herrschaften in the northeast of contemporary Switzerland, which was a joint enterprise by the alliance partners of the old confederation. The newly won territories enjoyed different statuses, but their autonomy was mostly maintained. Since 1410, Ursern had been linked to Uri as an abhängige Landschaft (dependent territory).

The Land Uri made use of its territorial expansion not so much because it wanted to extend its resource basis. We might thus assume that it hardly had an influence on the commons on its own territory. However, the expansion was an important pillar of the political and economic system into which the collective utilisation of these resources was embedded. It provided the families of magistrates with one of several possibilities to generate the wealth they needed for their paternalistic rule, as the compensation paid for the work of governing and administering Uri was low. Their style of rule was based on a marked clientele system that by way of social connections and dependencies (most of all debts, a network of relations and reputation) tied the individual citizens of the Land to the families of magistrates and ensured that their political careers were supported. At the same time, the office bearers were expected to make generous donations to the community, among others a dinner for the participants of the Landsgemeinde (Kälin 1991). 




Figure 5.4 The Landsgemeinde (assembly of entitled citizens) became a widely known icon of the political system of the Swiss Confederation in the late eighteenth and nineteenth centuries. This is one of many images showing the Landsgemeinde of Land Uri. Source: Staatsarchiv Uri. Painter and date unknown.

Nevertheless, the most important source of income for the leading families was the payment for soldiers. Since the Middle Ages, an independent system of military entrepreneurship had developed in Uri. From the sixteenth century on, it geographically extended its activities. Soldiers from Uri fought for the Italian, Spanish, French and Savoyard armies. Locally, this economic branch produced two effects in particular: first, as a result of many young men emigrating, it relieved the population pressure; second, by way of pensions paid by foreign warlords, considerable amounts of money swelled the coffers of the Land Uri, allowing the state to do mostly without taxes, which again relieved the pressure on natural resources. Thus, collective local exploitation which was not oriented towards intensification was combined with money coming in from foreign countries.

\section{Closing off and exclusion}

As was also true in many other regions, in Uri a trend of closing off from newcomers can be observed in the course of the Early Modern Period. Whereas in the fifteenth and sixteenth centuries the Landsgemeinde granted Landrecht (full citizenship) rather frequently and generously, in the seventeenth and eighteenth centuries there was a clear decrease in numbers and full citizenship 


\section{Rahel Wunderli}

became much more expensive. Although in Uri between 1650 and 1850 there was only a small increase in the population, there are clear indications in the eighteenth century that the ratio of resources and population density developed critically (Stadler-Planzer 2015a). Unfavourable climatic developments as well as natural disasters resulted in famine and a sharp demographic decline (Bielmann 1972).

However, closing off from outsiders must also be read as a political strategy to reduce the circle of potential candidates for political positions and related economic options. Indeed, from the late seventeenth and early eighteenth century on, that is, in the same period of time as when the circle of the Uri oligarchy was greatly reduced due to marriage practices, the rights of socmen and foreigners were also particularly limited. Their scope of action in the agricultural sector was limited with the help of regulations and utilisation bans and they were excluded from a variety of trades or, if still allowed, requirements were increased for them. Marriage between full citizens and outsiders was sanctioned: Uri women lost full citizenship (which granted them unlimited utilisation of the commons) and males from Uri had to pay bail money or else leave the country (Stadler-Planzer 2015a).

Woodlands and pastures as elements of the economic structures and dynamics of the Early Modern Period

In the Early Modern Period the pastures were not significantly extended; only in the nineteenth and twentieth centuries were considerable areas of cultivated lands newly added through changing the course of waters and via ameliorations mainly in the Urner Talboden.

\section{COMMONS VS. PRIVATISATION}

For the period from the sixteenth to the nineteenth centuries the existing sources document a number of successful attempts to transfer Gemeinmarch (common lands) into Eigen (private property) or to establish rights of special utilisation for certain plots. In this way, in several regions, so-called Eigenalpen (private alps) developed, owned by one family each. Individual villages or neighbourhoods successfully contested for special utilisation rights concerning areas in their vicinity or established such rights de facto by way of years-long utilisation. Partly these special rights were granted by the Landsgemeinde which also distributed the so-called Rüttenen: areas that first had to be cleared and, in the case of non-utilisation, became commons again. From the seventeenth century onwards, however, several regulations were introduced at Land level that rendered the privatisation of commons more difficult and made illegal appropriation punishable. Furthermore, control authorities were established with the task of recording the distribution of commons. For example, from the eighteenth century on, Alpvögte (alpine bailiffs) are documented, who needed to be elected by the members of the alpine cooperatives as their representatives 
and at the same time had to swear an oath to the Land Uri that they would ensure the enforcement of regulations in the areas under their control (StadlerPlanzer 2015a).

\section{UTILISATION RIGHTS FOR PASTURES AND FORESTS}

The most important regulations concerning the alpine pastures were their structuring into three utilisation zones: Bodenallmend and Heukuhweide (pastures near settlements); Alpen (pastures in remote and higher areas); and Geissweide and Wildheugebiet (steep slopes in remote and higher areas unsuitable for cattle). Furthermore, the regulations linked winter feeding capacities to the number of animals grazing on an alp as well as the property of an alpine hut to the right to drive cattle to an alp. The number of animals to be driven per owner was limited, and non-citizens were excluded from these ways of utilisation, or at least were put in an inferior position (Stadler-Planzer 2015a). With the exception of the regulations for winter feeding, these principles are still valid today, although many of their details have been adjusted to changed agricultural contexts. For example, until the 1990s the maximum number of cows that could be driven to an alp was 25 per owner. It was increased step by step and has been 50 since 2013. Thus, the system of pasture regulations allows for both a high degree of consistency and flexible adjustment (Wunderli 2016).

Many regulation principles meant for pastures can also be observed for woodlands. For example, the first woodland regulation passed by the Landsgemeinde in 1779 - individual villages had their own ones even at a much earlier stage - provided for a categorisation of woodlands, albeit according to owner and administrator rather than to way of exploitation. There were Eigenwälder (private woodlands) and forests owned by the Land. Most of the latter were administered by the village communities. Furthermore, woodlands that had additionally been allocated to two or more villages because of bigger numbers of inhabitants were excluded. Some areas were also reserved for special purposes, such as for timber used for flood prevention. Moreover, there existed the category of Bannwälder (protected forests), whose exploitation, due to their protective function for settlements, was subject to special limitations. Full citizens were basically entitled to certain amounts of wood, distinguished between firewood and timber, but the exploitation rights of non-citizens were greatly limited.

In the eighteenth century there were a growing number of decrees aimed at preserving the woodlands to a certain degree. The market-oriented utilisation of woodland products (timber trade, lime burning, charcoal burning, ore smelting) was limited insofar as any exploitation beyond one's home requirements had to be granted by the village community or the parish (Stadler-Planzer 2015a). The fact that today the Korporationsbürgergemeinden (communities of corporation of citizens) are in charge of woodlands can be traced back to this time, when wood as the main supplier of energy was mostly distributed and used at village level. 


\section{INCREASING AGRICULTURAL COMPETITION}

Generally, one may assume that the peak of agriculture in Uri was in the sixteenth to seventeenth centuries and that there was a period of stagnation in the eighteenth to nineteenth centuries owing to insufficient competitiveness. Obstructive factors were the marked small-scale design of local agriculture and a lack of innovation. For example, one did not succeed with starting any large-scale export of cheese because one did not move to the production of transportable hard cheese. Several initiatives for improving the situation were rejected, whereas in neighbouring Schwyz they were met with interest (Kälin 1991; Stadler-Planzer 2015b). However, traffic across the Gotthard Pass increased substantially in the course of the eighteenth century (Bielmann 1972; Marty 1951). As a result, the meadows along the pass road were increasingly rented out to cattle traders as pastures, or their harvest was sold.

\section{The formation of the Korporation Uri in the nineteenth century}

The Helvetic Republic as a shock and the re-establishment of the old order

With the invasion of French troops into Switzerland in 1798 and the enforcing of the Helvetische Republik, at a stroke the Land Uri lost all sovereign rights over its external territories. Like Ursern, which was now legally on equal terms, it became a Bezirk (district) of the Kanton Waldstätten. The privileges of full citizens compared to socmen (Hintersassen) were lifted according to the new state principle of the freedom of settlement and trade. This shock was intensified by the fact that several times Uri became a theatre of war and suffered greatly from the French and Russian troops billeted there. A series of devastating natural disasters and the destruction of Altdorf, the economic and political centre, by fire, exacerbated these issues. These immediate crises obscured the fact that long before the nineteenth century the political and economic system of the Land Uri had reached a dead end. The economic basis was barely differentiated, resulting in considerable vulnerability to external changes. For example, the general decline of mercenaries from the second half of the eighteenth century proved disadvantageous for the entire Land. The political culture of a paternalistic oligarchy combined with an extended collective utilisation system was aimed more at stabilising the social order than at facilitating business enterprises activities (Kälin 1991, 2004). All these factors resulted in a general trend of impoverishment, starting in the mid-eighteenth century and increasing in the course of the first half of the nineteenth century (Arnold 1994).

By its first constitution of 1803 Uri became a Kanton of the Swiss Confederation but largely remained stuck to the legal system of the Land Uri. Crucial for the future of the system of commons was one article of the canton's constitution that withdrew the power of disposition over the property of the two districts of Uri and Ursern from the Landsgemeinde, where socmen 
(Hintersassen) were now also entitled to vote. The following decades saw the reintroduction of some of the old privileges of full citizens, among others by way of a restrictive citizenship and settlement policy.

The second cantonal constitution followed in 1850. It was oriented towards the principles of the new Confederation and distributed the responsibilities of the various political authorities according to the principle of the separation of powers. Nevertheless, in several areas of the arrangement of authorities there remained parallel responsibilities and non-transparency and the Bezirk Uri was consequently accused of being incapable and inefficient (Stadler-Planzer 1980).

The road towards separation: the debate over basic issues of the commons

With the revision of the canton's constitution around 1850, in Uri there commenced a debate regarding basic questions of how the previous property structure with its high share of common lands was to be maintained and, if so, how these common lands were to be organised and administered. The debate took place in different topical fields and lasted for several decades. Two questions were key. First, should the common lands be administered by an authority covering all villages as before, or did smaller administrative units make sense? Second, what status was the administration of the commons to have in the future political system? The first question, that of how administration was supposed to be organised, boiled down to the keyword Allmendteilung (distribution of the commons to the communities), which was to be voted on 12 times in the course of 70 years. This debate peaked and at the same time came to its end with the application, handed in to the Korporationsgemeinde in 1918, by way of which 58 citizens of Göschenen petitioned for their community to leave the Corporation. The second issue, that of the status of the commons within the political system, was discussed in the context of the revision of the canton's constitution and peaked with the abandonment of the two Bezirke Uri and Ursern as well as the separation of the two commoners' organisations from the canton's authorities, establishing them as corporations in 1888 .

However, let us go back to the beginning of the debate. In 1848, the year when the new federal constitution came into force, the representatives of seven families from Uri made a motion with the Landsgemeinde demanding the distribution of the commons among the communities, which in those days were not yet organised as municipalities. They aimed at a more efficient cultivation of the collective resources. Thereupon, a commission was established to assess this suggestion for its feasibility. In 1852 it presented its report, which contained a majority and a minority motion. With the exception of one member, the commission was of the opinion that such a distribution would result in severe conflict because the principles of such a distribution were highly disputed. Furthermore, the commission members contended, a municipal citizenship concerning Armengenössigkeit (social welfare) would have to be introduced, which they wanted to prevent because of its grave financial consequences. 
Fierce debating, immense administrative efforts as well as legal claims to welfare in case of poverty, which would be dangerous for the communities, were predicted. The only commission member speaking in favour of distribution the former Landamman Vinzenz Müller - argued that distribution was in line with the current trend of

our original organisation as one common community of the entire ancient Land Uri with originally only one common citizenship, only one common social welfare [...], only one common goods corporation, being in a gradual transition to separate communal citizenships [...] and that sooner or later this transition will result in completely dissolving into separate communal cooperatives. ${ }^{15}$

The common lands were too extended, he said, to be efficiently administered by one authority alone. Moreover, if the communities were to bear the greatest burden of social welfare, they would need to be provided with appropriate resources. His suggestion aimed to balance the economic disparities between cattle-owning citizens and those without cattle.

This attempt at a distribution from which not only the cattle owners would benefit but which would also consider the interests of all other entitled citizens rendered Müller's suggestion for distribution quite complicated. Several zones of utilisation - Heukuhweide, Alpen, Geissweid and woodland - should each be distributed according to a different way of calculation: the number of inhabitants in one case, the number of winter-fed cattle in the other. The grazing fees should be increased and the citizenship of a person should be fixed once and for all. The suggestion was rejected by the Landsgemeinde.

Until the separation of the Corporation in 1888, five more motions concerning this matter were put to a vote. Finally, in February 1887, the Bezirksrat (district council) passed the motion by a council member who once again demanded a commission that was supposed to assess the question of possible approaches for a distribution of collective resources among the communities. According to the newspaper Urner Volksblatt, which vehemently supported distribution, this time the suggestion was practically uncontested and the commission consisted almost entirely of "friends of the distribution". ${ }^{16}$

However, before this commission could start its work, the issue of the distribution of the commons was pushed aside by the debate concerning the revision of the canton's constitution. It was this second topical field where the future of the commons was ultimately decided.

\section{The separation of the Corporation in 1888}

Already in the run-up to the canton's constitution of 1850 , a debate was initiated regarding the question of how far it was advantageous for the commons 
to no longer be administered on the basis of traditional, exclusive utilisation rights, but by a state authority functioning according to modern principles of the freedom of settlement and the freedom of trade as well as individual political rights. In this context, Ursern's new status played an important role; for by this valley community gaining political sovereignty, the competences of the two Bezirke Uri and Ursern as well as that of the Bezirksgemeinde (district assembly) had to be renegotiated (Stadler-Planzer 1971). Furthermore, the municipalities, whose legal position was strengthened by the federal constitution of 1874, threatened to blow up the existing political system. The status of the municipalities became a major driving force for the separation of the commons from state administration. It was finally realised in 1888 by the revised constitution of the canton. Three fifths of those present and entitled to vote passed the new constitution (Stadler-Planzer et al. 2013).

After the separation of the two Korporationen Uri and Ursern under public law, the debate concerning the distribution of the commons flared up once again. On the occasion of the first assembly of the Korporation Uri on 21 October 1888, the Korporationsrat (legislative board) presented a suggestion for the distribution of pastures and woodlands among the communities, which had been worked out by the Bezirksrat. It was rejected with a majority of two thirds of the votes (Stadler-Planzer et al. 2013). Concerning this matter, there followed three more motions in 1904, 1910 and 1916, all of them presenting specific suggestions concerning the mode of distribution. They were rejected, like the above-mentioned request by Göschenen to separate its territory from the Corporation. Following this decision of 1918, the topic was not taken up again, which was an important step towards the consolidation of the Corporation.

Woodlands and pastures as elements of the economic structures and dynamics of the nineteenth century

\section{STEPS TOWARDS MODERNISATION}

The first half of the nineteenth century must be called a time of crisis for the Kanton Uri. The discrepancy between demographic pressure and food resources, which had already become serious in the course of the eighteenth century, grew even further. There were too few opportunities to make a living apart from agriculture and these were also financially insufficient to compensate for the losses caused by the end of the ancient régime and the damage from around the turn of the century. Broad parts of the population became impoverished. The political system reacted in a defensive way, finding expression in a repressive press and censorship policy (Zurfluh 1993; Kälin 1991). Moreover, closing off from outsiders peaked.

At the same time, some differences between members of the peasantry were growing, including between livestock owners and those without livestock. 
The latter benefited much less from the commons, as they could not use the alpine pastures. However, they were represented to such a degree that the commons regulations were adjusted in their favour. For example, in the 1830s the Landsgemeinde passed a motion demanding the extension of garden plots to the commons as well as the distribution of commons gardens, which was supposed to be differentiated according to economic status.

In Uri, ideas concerning the intensification of agriculture, which since the eighteenth century had been met with strong responses in many places across Europe, including in Switzerland, continued to be rejected in the first half of the nineteenth century. This started to change only from 1850 onwards. One of the first projects aiming in this direction was the channelling of the Reuss in the Unner Talboden, which was realised between 1850 and 1870. Added to this were the first attempts from the mid-century on to improve cattle breeding, in order to become more competitive in the cattle trade.

The woodlands especially suffered from population pressure. The report by Swiss forest expert Elias Landolt about Uri spoke of damaged forests and particularly denounced the cutting down of young trees. He stated that the practice among the peasants was to sell the wood they were entitled to by their rights to the commons and to meet their own requirements by way of illegally harvested timber. In Uri at that time, about 30 sawmills were operating and processed 50 per cent of the harvested timber. Firewood was exported to Lucerne while saw timbers and other wood products were taken to larger markets.

When Landolt, at the request of the district authorities, presented a suggestion for a forest law in 1869, it was rejected by the Landsgemeinde. Later on, however, neither the canton nor the Corporation could evade the Bundesgesetz über die Forstpolizei (Federal Law on the Forest Police) of 1876. The first senior forestry official took office in 1878. Nevertheless, the forest authority still encountered conflicts and it took until the 1930s before all forests in Uri were cultivated according to forestry plans (Stadler-Planzer 2015b; Oechslin 1927).

In the second half of the nineteenth century, the economic situation of Uri started to become less tense. An important reason for this was the construction of the Gotthard Tunnel in the 1870s and 1880s.

\section{The Korporation Uri as an element of the canton's political structure in the twentieth and twenty-first centuries}

This final and most detailed section on the history of the Corporation does not provide a chronological presentation but rather focuses on several aspects of positioning experienced by the Corporation after 1888. The focus lies on the organisation's different strategies of dealing with political and economic change. ${ }^{17}$ The historical context within which the Corporation acted during 
this period is described in Chapter 2, in the sections titled 'Adopting new roles in the twentieth century' and 'The polarisation of utilisation in the 'consumption society'.

\section{Relevance}

Despite the weaker position of the two commons organisations within the political structure after the separation of 1888, in the course of the twentieth century and still today the Korporation Uri exerts considerable political influence and is broadly rooted in society. It is by far the biggest landowner of the canton and in the course of more than 100 years the share of inhabitants holding corporation citizenship fluctuated between 60 and 80 per cent (StadlerPlanzer et al. 2013). ${ }^{18}$

Apart from the quantitative dimensions of being interwoven with society, there are also qualitative dimensions. One example is decentralised organisation: in all 17 municipalities belonging to the territory of the Corporation, today Korporationsbürgergemeinden (communities of corporation of citizens) are active as independent corporations under public law. They cultivate and administer woodlands and alpine pastures and carry out further tasks, such as the maintenance of local roads, the distribution and administration of commons gardens and - up to now - the handing out of the Bürgernutzen (citizens' benefit). ${ }^{19}$ Thus, apart from the staff of the Corporation Chancellery in Altdorf (8 people) and the members of the two boards Engerer Rat and Korporationsrat (41 people), for each of the 17 Korporationsbürgergemeinden the members of their councils, Bürgerrat (5-7 people each) and audit commissions ( 2 people minimum each) must also be counted among the active staff of the Corporation. Therefore, the commons administration is well provided with staff and premises. Moreover, the example of the Korporationsbürgergemeinde of Bürglen, which since 2014 has been presided over by a hairdresser and where the Bürgerrat represents a broad mix of professions, illustrates that the organisation is even capable of including people without any professional relation to their main activity, the administration of natural resources. Although this heterogeneous structure sometimes makes decision-making difficult and leads to tensions, it gives expression to the Corporation being functional as a widely branched social network and of being able to unfold integrative power. However, the arguments in support of the Corporation being socially relevant must also be weighed and relativised under the perspective that this relevance, given different developments since 1888, is not a matter of course, but must be constantly worked for, sometimes in the face of considerable resistance which, in the form of the historical processes described in Chapter 2, contradicts the inherent goals of such a corporation.

During interviews with representatives of the Corporation, this legitimisation work frequently became a topic of conversation. For example, the Corporation scribe Pius Zgraggen explained the swift agreement by the 
Corporation to provide the SCALES research project access to the archive as follows:

We are glad that there is interest in our corporation and that somebody considers the qualities, the advantages and disadvantages. If somebody else has a look, this might indeed mean that there is something of interest.

To the interviewer's subsequent question regarding whether the organisation is not met with interest from outsiders, he answered:

Rather not. [...] Here in Uri we are well-integrated indeed, but these days the citizen or inhabitant is not so much active in agriculture and thus there develops some distance. Those still [...] active in cultivation people engaged in alpine farming - are close and know the Corporation. However, as far as all the others are concerned, the Corporation finds it rather difficult to explain what we are doing. That is continuous work to be done. ${ }^{20}$

Thus, it is in the field of tension between "being well integrated" and "constantly having to do difficult explanation work" where the social relevance of the Corporation must be located, and it must be asked by help of which strategies it has attempted to exert its influence within the political structure.

\section{Corporation and canton: competition ...}

Particularly crucial for the structure within which the Corporation exists is its relationship with the canton. One speaks of a "state within the state". Indeed, the fact that after so many centuries of cross-village authority over the commons, the administration of the collective resources of the Bezirk Uri was separated as a corporation from the canton's administration and structure of authorities in 1888, has left its marks even today. The view of the Corporation has always been on the entire region; its habitus - particularly in the first half of the century - has been that of a state actor. This becomes obvious from the fact that in 1904 the Corporation founded a new office, the Kulturamt, to mobilise scientific know-how and state funding for the various amelioration and infrastructure projects concerning the commons. Two years earlier the canton had passed a decree concerning alpine improvement and promising money for such projects, but concerning this matter the Corporation clearly felt that it was in charge and took over the role of initiator. When in 1910 the board was taken over by the canton - because from that time the state was only paying the wages of Kulturingenieure (the engineers planning such projects) employed by the canton - it still reserved an extended right to a say concerning staff decisions and organisation, which came to an end only after the board was integrated into the canton's forestry authority (Viallon et al. 2019). It took 
considerable effort to maintain its influence on the canton's forestry and agricultural policies for as long as possible, despite legal restrictions.

To the same category belongs the Alpinspektion (inspection on alps), which was initiated by the Corporation shortly after the turn of the century and was published by Corporation Scribe Ambros Püntener (Püntener 1909), according to the model of earlier inspections by the Schweizerischer Alpwirtschaftlicher Verein (Swiss Association of Alpine Farming) (Gemeinnützige Gesellschaft Uri 1884). Thus, the Corporation positioned itself as an agent of the modernisation of alpine farming - at the same level as the canton, which at that time started making its mark as an actor in the field of agricultural policy. Accordingly, shortly after the turn of the century it built a modern, gigantic stable on the only alp it administered (Ruosalp) (Wunderli 2016).

In the 1920s, the Corporation supported a huge amelioration project, during the course of which the Urner Talboden on the right banks of the River Reuss was drained to allow for more intensive cultivation there. This megaproject crucially benefited from political and financial support from the Corporation, which made use of it as a platform to demonstrate its creative power and interest in modernisation. Accordingly, after the project was finished it mostly gave up on utilising the ameliorated parts as commons and sold or leased several plots "so that these would be rationally cultivated" (Bricker 2018, p. 93).

Another, still current, example of the Corporation's self-understanding as a state actor is its way of staging the assembly of the corporation citizens, the Korporationsgemeinde, as the continuation of the Landsgemeinde of the Land Uri which was abandoned in 1929 (Stadler-Planzer 2015b). Not only are some of the details of the procedures similar - such as the parade on the occasion of the official opening - but also important symbols of the Landsgemeinde have been adopted. For example, the so-called Ring, a wooden installation resembling an amphitheatre where citizens who are entitled to vote stand during the assembly, was designed according to the model of the Landsgemeinde-Ring and some wooden elements of the original are still in use today. Furthermore, the so-called Harst - a group of males in disguise representing figures from the time of the Land Uri, including mercenaries, heralds and the heraldic animal the bull (Sauter 2017) - by their presence during the assembly implicitly give the impression that the Corporation is the successor to the ancient Land Uri (see Figure 5.5).

Karl Marty, for years one of the commons supervisors and in charge of constructing the Ring, described the occasion using another keyword:

This has very much got to do with tradition. This whole procedure, building up the Ring, means comparatively considerable effort for [an occasion] that might as well happen at the Tellspielhaus (the theatre in Altdorf). [...]. Building up the Ring and being outside in any wind and weather ..., then the entry, ... it's very traditional, and indeed this is what attracts people. ${ }^{21}$ 


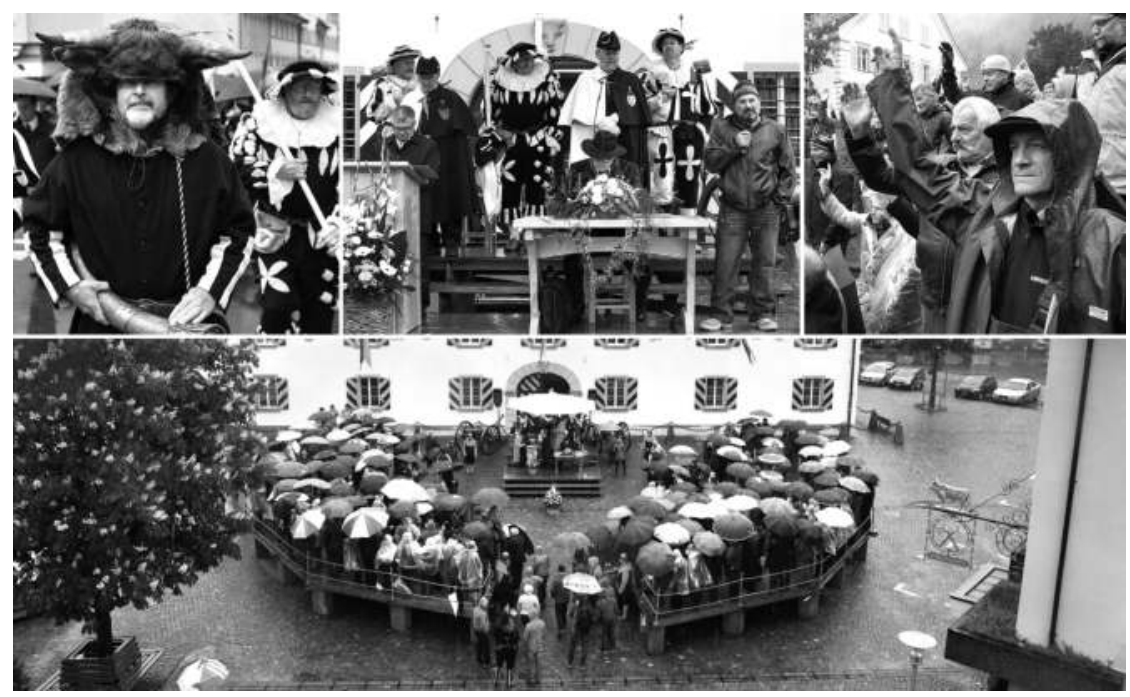

Figure 5.5 Images of the Korporationsgemeinde 2019. Photographers: Peter Studer/Pipaluk Minder.

- Picture below: Due to the much smaller number of citizens participating in the Korporationsgemeinde these days, the Ring now has the shape of a semicircle rather than that of a full circle, as displayed in historical images and photographs (compare Figure 5.4). Nevertheless, the word is still in use in several common phrases. For example, at the beginning of the assembly the citizens are told to "step into the Ring", meaning to exercise their rights.

- Picture top left: Parade through Altdorf's main alley to Lehnplatz, where the assembly takes place. An important element in this context is the so-called Harst.

- Picture top centre: Those who take the floor in the discussion rounds step up to the lectern and address the assembly. A convincing presentation requires rhetorical skill and experience.

- Picture top right: The votes happen in public. Indeed, the voting of individual members as well as the final result can be watched by everybody.

Political self-staging? Tradition? Political self-staging as a tradition? It is difficult to say which aspect dominates and in what ways these aspects are interwoven. For the time being, the question remains unanswered.

The ongoing self-understanding of the Corporation as a "state within the state" must also be read as the result of a purposeful personnel policy. As late as the 1980s, with one exception, all of the corporation presidents came from the political elite. They were either close relatives of the presidents of the canton government (Landammänner), or were members of the federal or canton parliaments before or during their time as corporation presidents. More than a few had graduated from university (Stadler-Planzer et al. 2013). It is certainly also due to the political weight of these office bearers that the Corporation has 
frequently been successful in its struggles with the canton regarding competences in the course of the first 70 years of its existence.

One example is the compensation the Corporation paid to the canton for taking over the expenses for flood barriers and roads after the separation of 1888. Of the three amounts suggested by the different committees of the canton - 350,000 Fr., 300,000 Fr. and 280,000 Fr. - the Landrat, the legislative body of the canton, chose the lowest, which was only 10,000 Fr. higher than the suggestion made by the Corporation during the negotiations. At the time, one newspaper journalist called this amount "definitely too little". In this way, the author claimed, the canton would lose several thousand francs a year, and even more, as the compensation was paid in woodlands, plots of land and buildings. $^{22}$

Another example of struggles between Corporation and canton are the negotiations regarding water utilisation rights, which were initiated by the Corporation at the beginning of the 1950s and during the course of which it went as far as to appeal to the highest state court (Stadler-Planzer et al. 2013). Whereas the negotiations between canton and Corporation around 1888 were comparably moderate, the issue of water utilisation rights resulted in open conflict. The Corporation successfully contended for the right to issue licences for water power in a tributary valley of the Reuss, where at that time the waters owned by the canton were increasingly used for electricity. In this case, the Corporation defended its interests vehemently, because at that time the development of water power was extremely dynamic and high intakes could be predicted. As a matter of fact, the right to issue water power licences by the Corporation soon produced revenues that became by far the most important source of finances.

The examples above suggest a relationship between canton and Corporation that was fairly competitive. This impression is supported by recent episodes, such as the negotiations regarding the contract within the Schutz- und Nutzungskonzept erneuerbarer Energien (SNEE) (Concept for the Protection and Utilisation of Renewable Energies). The concept was presented by the canton in 2012 and at first was rejected by the Korporationsrat. But the following year, after an adjusted contract had been worked out, it was passed by the Korporationsgemeinde. Karl Marty described the concept as a reaction to the plans for extending water power triggered by the Federal Council's decision of 2011 to cease nuclear energy production. In the canton there had been a certain degree of resistance from environmental protection associations to these plans. In response, the canton worked out a concept that divided the waters into those to be protected and those to be utilised:

It turned out that most of the waters to put under protection were owned by the Corporation. The bigger waters one wanted to utilise and which would produce revenues were owned by the canton. The Corporation refused to accept this. 
In the course of the subsequent negotiations the concept was adjusted. The bigger, canton-owned, waters were separated for the purpose of energy production and the Corporation was obliged to have its own (smaller) waters protected. At the same time, it was stipulated that the canton would compensate the corporation for this loss of income by giving it a share of its grants. Marty pointed out that to his knowledge this was the first time that the Corporation had completely given up on its utilisation rights.

This episode illustrates the still intact negotiation power of the Corporation, which is mostly characterised by its position as a landowner. In addition, the example demonstrates the rivalry in which the Corporation considers itself engaged.

\section{... and more facets}

However, it would be misleading to speak of a relationship between Corporation and canton that since the separation has without interruption been characterised by competition. In the course of the past century, the relationship has changed considerably in several respects. On the one hand, the canton's constitution of 1984 must be mentioned. In contrast to that of 1888 , no longer was the focus on protecting the Corporation against interventions by the canton, ${ }^{23}$ but on the former's obligation to support the latter as well as the municipalities with fulfilling their tasks. ${ }^{24}$ This may be read as a legal downgrading or at least a limitation of its scope of action. However, the fact that today even the Corporation points to its support function for the public sector rather allows for the conclusion that being given this position and the thus increased integration into the political structure is rather perceived as supporting one's own legitimacy. As Pius Zgraggen stated: "[As a corporation] you can only survive if you are given a task". As additionally clear in his quotation above about the need for constant explanation work, in today's society, where the peasant population is only a fraction of its former size, it is not easy to communicate this task: "We've got the canton and the municipalities. In terms of state structure, it really needs explaining what the Corporation means and one must again and again point out what we are doing". Consequently, in public statements the Corporation representatives predominantly refer to those aspects of their activities as appealing to a population that is characterised by an urban lifestyle: providing public access to the shores of Lake Lucerne, for example, or the sponsoring of various events in the canton.

In this social context, which has been legally redefined by the canton's constitution of 1984, it is also important to read the above-mentioned conflict with the canton regarding the SNEE contract as an opportunity for the Corporation to present itself as an organisation acting in the interest of the entire population of Uri. Accordingly, Zgraggen mentioned that in the course of the SNEE negotiations, one would demonstrate that "one does not dig in one's heels". Rather, one would offer a hand and declare one's readiness to have the waters protected which, according to Marty, must be interpreted as 
giving up on utilisation rights and, in view of the organisation's logic of action, as an extraordinary concession.

Another aspect of the relationship between Corporation and canton are the at-times closely interconnected administrative procedures and financial flows of the two organisations. Former accountant Franz Dittli offered an example. Currently, the Corporation is in charge of accounting for 10 out of the 17 Korporationsbürgergemeinden because they do not have any scribes with accountancy skills. Accounting, he explained, consists of the total accounting of costs as well as of cost accounting for woodlands (remember that the Korporationsbürgergemeinden are in charge of administrating and cultivating the Corporation's woodlands):

We account the costs of the woodlands of each Korporationsbürgergemeinde in cooperation with the canton's forestry board. Their total accounting of costs again serves as the basis for the Corporation to pay dues and subsidies, in addition to payments by the canton. Concerning woodlands, for example, there exists a contract with the canton about tending for protective forests which says that the Corporation pays another 30 per cent of the donation by the canton to the Korporationsbürgergemeinden. [...] The dues for woodlands are paid via the canton. The canton receives payments by the confederation, adds its own dues and then additionally receives the dues paid by the Corporation. And then the canton cashes this out and states an account accordingly. ${ }^{25}$

With alpine farming, too, the financial flows are complex. In the context of the SCALES project, Loris Spycher investigated the various payments among livestock owners, summering farms, alpine staff and Korporation/Korporationsbü rgergemeinden for one alp in Uri (Spycher 2018). Concerning the contributions by the confederation alone, four different categories were distinguished: summering contributions, alp contributions, contributions for maintaining landscape quality and contributions in support of biodiversity areas. The latter two were added after the turn of the millennium, in the course of the ecologic reorientation of agricultural policy. Cattle owners pay the Viehauflag (cattle fee/grazing fee) and the Schwendgeld (contribution for the improvement of alps) to the Corporation and are vice versa paid by it for extra hours of work in the context of the improvement of alps. If milk is processed on an alp, there are additional transactions among the cattle owner, the summering farm and the confederation/canton.

Other than for woodlands, there are currently no administrative interconnections between canton and Corporation concerning financial flows in the context of alpine farming. In the course of the 1990s the canton decided to cash out the state's contributions for alpine farming it received from the national board of agriculture to the alpine farms and no longer handed them over to the two corporations that had been in charge of administering them (Wunderli 2016; Land- und Fotstwirtschaftsdirektion Kanton Uri 1990). 
Now, however, an administrative interconnection between canton and Corporation concerning data is in the making. Marty explained that the increasing digital recording of livestock at the national Tierverkehrsdatenbank (livestock traffic database) (TVD) has forced the Corporation to make a decision about adjusting its supervision of the alps: "When we need information about how much cattle is driven to our alps, we approach the canton and ask them, for they have all those surveys about the usual number of cattle driven to the alps". However, such a data transfer also has its pitfalls:

We must always be able to attribute each animal to an owner. But even if the TVD tells us about the person driving the animal to the alp, we still do not know about the owner. [...] For the canton authorities this is an irrelevant factor. They don't care if the owner is from Uri or not. But we must know about this because the grazing fee is calculated according to it. Thus, we must see how to make adjustments in such a way as to make it irrelevant for us as well.

However, he said, a standardisation of the grazing fee requires considerable effort and would produce winners and losers, which is why it was so difficult to have it passed by the Korporationsgemeinde. It might as well be that the Corporation switches over to self-declaration, with additional random tests, to spare the costs of elaborate checks on the spot. In any case, he stated, it is clear that several possibilities for adjusting the system must be assessed.

Thus, the administrative interconnections between canton and Corporation are different from field to field and are subject to constant change. Due to the Corporation's considerable property, the Corporation's and the canton's policies overlap in numerous ways and constantly result in points of contact at the administrative level. This was also clearly stated in the interviews with Corporation representatives. Indeed, Pius Zgraggen emphasised that the Corporation must cooperate with several units of the canton administration and indicate its activities to each of these units. Also concerning information density, for them, being a small chancellery, it is not easy to make a stand against the canton authorities. These, Zgraggen claimed, have specialised staff for each field, whereas those who work at the Corporation's chancellery are "generalists and practitioners". Each according to necessity, the Corporation reaches back to external experts, as its administrative team is unable to cover the complexity of certain businesses.

Thus, the development of state administrative structures puts a local organisation such as the Korporation Uri under considerable pressure to adjust and threatens its political influence. Reactions by the Corporation to the rising demands in this field could frequently be identified in the interviews and the literature: for example, Zgraggen noted that he, as the head of the corporation chancellery, has completed a course in public administration and still attends further education classes in this field. Furthermore, in 1992 the Corporation hired the financial expert Franz Dittli and, after his retirement, replaced him by banking 


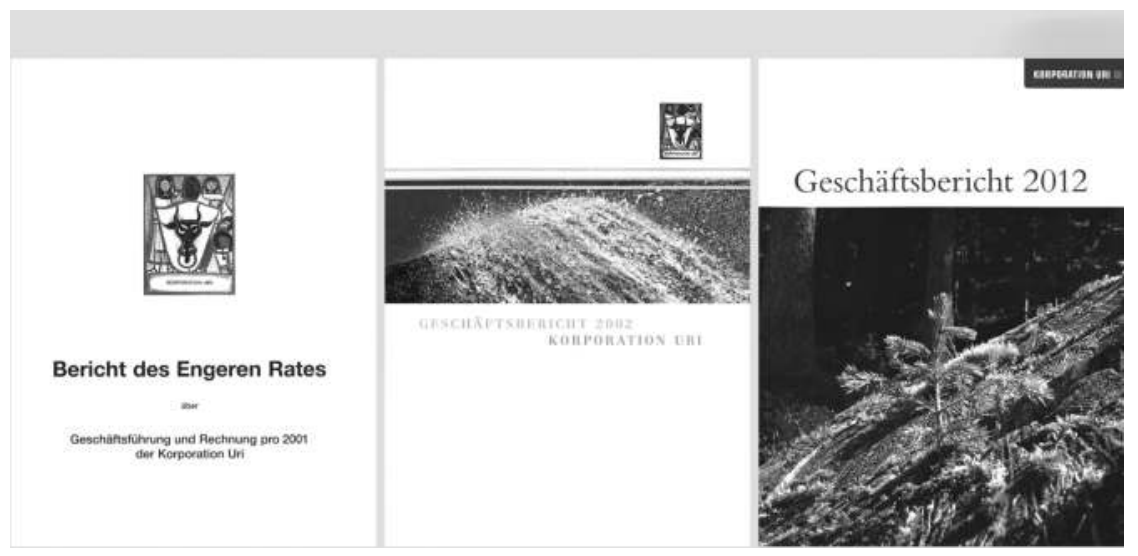

Figure 5.6 The front pages of the annual reports of 2001, 2002 and 2012 illustrate the fundamental and rapid change of the Corporation's means of communication after the turn of the millennium. The layout on the left showing the logo of the bull of Uri had been in use without change since 1953.

expert Ralph Lussi. Professionalisation in the financial field has occurred due to the fact that at around the turn of the millennium the Corporation developed a new investment strategy. Indeed, Dittli crucially contributed to diversifying the financial investments of the Corporation. Apart from bonds, now one also invests in shares. Another step towards adjusting to modern administrative demands was the systematising and updating of the Corporation's decrees and their editing in the new Rechtsbuch (Law Book) at the beginning of the 1990s. Also concerning its communication towards the outside, the Corporation has changed markedly since 2000 , including completely readjusting the layout of its printed publications (see as an example, Figure 5.6).

\section{Adjustment vs. resistance}

In the past 30 years covered by the interviews, the Corporation of Uri has in several respects proved its capability to adjust to rapid change in the fields of politics, economy and society. This is nothing new. The above-mentioned episodes about the modernisation of alpine farming or about utilising water power demonstrate that already at an early stage the Corporation had a good sense of contemporary trends. It has maintained this trait also when in the 1980s the peasant and trade milieu started dominating the presidency (StadlerPlanzer et al. 2013).

Apart from this basic readiness to adjust, however, there are also elements of insistence and explicit resistance against the spirit of the time. For example, I file the rituals around the Korporationsgemeinde under the former and the refusal against suffrage for women under the latter. 
In terms of canton matters, women's suffrage was passed in Uri in January 1972, one year after having been introduced at the national level. A few months later, the voters of Uri passed a referendum for the introduction of integrated suffrage for women at municipal and corporation level. However, an appeal by the two corporations of Uri and Ursern, which referred to the canton's constitution and their stipulated competence of self-organisation, prevented its implementation (Z'graggen 1999). Three times the Korporationsgemeinde rejected motions in this respect: in 1973, 1981 and 1987. Only in 1991, after the national Federal Court had introduced by legal decision women's suffrage in the canton of Appenzell Innerrhoden and an appropriate decree was also looming for corporations under public law, was the breakthrough achieved.

Indeed, when considering the history of the Corporation after 1888, the exclusion of women from decision-making is striking as the element by way of which the Corporation risked becoming politically irrelevant and thus suffering severe harm. From today's point of view, this element is not worthy of a "state within the state" and was not in those days either. At least this is how some of the statements by the interviewees may be interpreted. "The Corporation introduced women's suffrage only at a very late stage. For many this was a gigantic problem”, Marty noted. Moreover, Zgraggen remarked: "One does not really want to be reminded of the arguments stated in those days". Dittli described his change from banking to the Corporation as the "best career decision in my life", but right at the beginning of the interview he mentioned his irritation with the debates regarding women's suffrage that took place one year before he started working there:

At that time I attended the Korporationsgemeinde, [...] the issue was women's suffrage. For the Corporation in those days this issue was very exotic and some of the statements uttered made me shake my head, not really by leading authorities of the Corporation but by citizens who felt that if women were to become politically active within the Corporation, their families would start starving at home.

Isn't it remarkable that concerning the issue of gender relationships, for over 20 years the Corporation stood against the national as well as the cantonal trend, thus risking serious damage to its reputation and influence as a political actor? As an indication that this risk is not merely a retrospective interpretation but was already in the air in those days, I refer to the following contemporary sources.

In 1983 the Uri opposition newspaper Alternative published a detailed portrait of the "unknown Korporation Uri". The starting point for the journalist was this statement: "By far the greatest share [of the entitled citizens] do not make use of the rights they are entitled to. Either because they consider the Corporation to be folklore or exclusively a matter of farmers" ${ }^{26}$ According to 
the subsequent analysis, when it comes to granting licences the organisation cares too little about environmental issues, while concerning women's suffrage it is on "its own reactionary trip". It is, according to the article, dominated by people acting as a brake as well as by "women-haters".

In addition to this left-wing evaluation, which in the context of Uri might be shrugged off as a minority opinion, are the statements made by Corporation president Josef Herger, who resigned in 1997. What he told the Neue Urner Zeitung also suggests that at that time the position of women in the Corporation was crucial for the organisation's reputation. To the remark by the journalist that "frequently the Corporation is called a cumbersome, conservative organisation dominated by only a few", Herger responded by pointing out that the Corporation had extended its communication towards the outside and was no more cumbersome than other organisations. Then he added:

Maybe we are called "conservative" because, among others, just two women are members of the Korporationsrat. However, this is not only the men's fault ... Then there is the fact that in the Corporation, women's suffrage was introduced as late as in 1991. The share of women will certainly rise when there are more women interested in contributing. And I suppose it's only a question of time until a woman will be elected to the Engerer Rat. ${ }^{27}$

There were 14 years between the article in the Alternative and the interview with Josef Herger. Thus, both times the position of female, entitled citizens was given as a crucial feature of how the Corporation was perceived by society. This is a strong indication in support of the hypothesis that the resistance against women's suffrage had led the Corporation into a political dead end and a reform deadlock, which was broken by passing women's suffrage in 1991. This can also be read from the modernisation pushes after 1991 described above.

In this context, it must also be mentioned that already before 1991 the question of gender relations within the Corporation had been set in motion, triggered by the new, nationwide marital law passed in 1988. As a result, the Corporation was banned from withdrawing corporation citizenship from a female citizen who had married a non-citizen. Step by step the Corporation started offering the possibility of regaining citizenship to women from whom it had been withdrawn due to marriage. For the time being, the last step of this development is the granting of the possibility to the descendants of women who had lost citizenship since 1888 to provide evidence that they are descended from a former female corporation citizen and in this way have their own citizenship stated. Furthermore, today the children of the Corporation's female citizens are granted citizenship by birth. Thus, the previously blocked female line for passing on or bequeathing this right has now been opened. 
Consequently, this decree has generated a considerable number of new corporation citizens. Indeed, between 2007 and November 2019 the Corporation issued 460 so-called Feststellungen (statements).

Thus, the introduction of women's suffrage and the formal recognition of women as full citizens must be considered turning points in the history of the Corporation. Therefore, they should be analysed more closely. Which people, groups or milieus actively contributed to these conflicts? What were their life-worlds and value systems like? How did they concretely behave during the political process? Crucially, into which historical long-term developments could the decisions by the Korporationsgemeinde of 1991 and 2007 be integrated when analysing them as belonging to a typical feature of such organisations, that is, excluding certain parts of the local population?

As a preliminary conclusion on the political structure, we may state a remarkable continuity of power relations since 1888. Despite, and in fact because of, all the changes to its profile, the Corporation has been able to maintain its position as an influential actor. In this context, its own history has first of all been a reservoir of experience, knowledge and prestige. However, this history may also become an obstacle - even a threat - that can only be overcome or prevented by way of giving in to pressure from the outside. On several occasions, making use of external (knowledge) resources proved to be an important strategy. Ultimately, the Corporation has survived, among other reasons, because, apart from assertiveness and delimitation, contextual cooperation has counted among the repertoire of its actions.

Woodlands and pastures as elements of the economic structure and dynamics of the twentieth and twenty-first centuries

At the beginning of this chapter the close interconnection of organisation and resources was addressed and it was stated that the Corporation has inscribed itself into the terrain. For the twentieth and twenty-first centuries this statement is not first of all based on the utilisation regulations issued by the Corporation. This mechanism actually holds for all periods under discussion here. Rather, for slightly more than 130 years, a number of infrastructural and amelioration projects have been carried out or at least (co-)funded by the Corporation. These projects clearly characterise the landscape. When speaking of "inscribing into the terrain", it must also be mentioned that the local control work, documented as early as the eighteenth century, continues to this day. A considerable proportion of administrative work happens still outside. In this context, the six Allmendaufseher (commons supervisors) do by far the most. By decree they are obliged to inspect the borders of the area of which they are in charge at least every two years and to inspect the alps, deposits, corporation roads and so forth once a year. They are also in charge of reporting on the clearing work done by those cultivating the alps. One speaks of a share of work of 40 to 50 per cent per supervisor. Several interviewees described how as children they viewed the commons supervisors as persons of authority and 


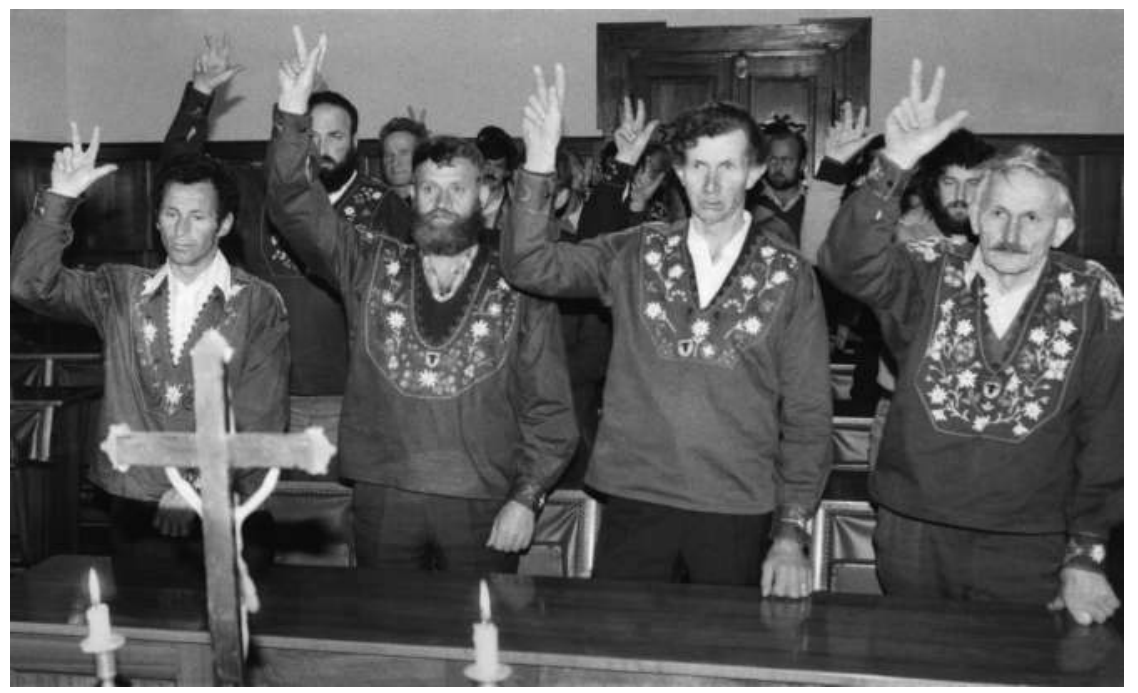

Figure 5.7 Picture on a newspaper announcement of the swearing-in ceremony for the herdsmen and alpine bailiffs at Altdorf City Hall, April 1985. Source: Staatsarchiv Uri, Luzerner Tagblatt.

as representatives of the Corporation: "As a child in those days one knew that it was kind of an event when the Allmendaufseher arrived"; "As a child, for me the Allmendaufseher were the Corporation". Thus, physical presence on the terrain affected the social influence of the organisation in a way that should not be underestimated.

Furthermore, the Alpvögte (alpine bailiffs, representatives of the alpine cooperatives) are important actors when it comes to enforcing the laws made by the Corporation and there is evidence of them existing over several centuries. As shown in Figure 5.7, the event at which they were sworn in was communicated to the public even in the late twentieth century. By way of this ritual, on the one hand they committed themselves to obey the regulations of the organisation and to take over the responsibilities connected to representation, while on the other, they were symbolically backed by the organisation, which was something they needed in cases of conflict.

\section{CHANGING NATURAL RESOURCES}

As concerns the changing functions and significance of woodlands and (alpine) pastures during the twentieth and twenty-first centuries, please see Chapter 2. Here, remarks from the interviews and results from literature are presented to show how the thorough and rapid change affected the local resources.

Concerning woodlands, Josef Herger, who was born in 1930, was corporation president from 1995 to 1997 and dealt with wood throughout his professional 
career ("for 50 years I used to be a woodchopper, a sawyer and a timber merchant"), presented some benchmark figures regarding the thorough change of this resource:

The economic significance of forests and alps has massively changed. Today, timber is practically worthless. In the past, we had 10 sawmills in the canton of Uri, all of which could more or less make a living from it. ${ }^{28}$ Today, in 2018, there is just one. [...] Shortly after the year 2000 there was a wave of closures.

Mechanisation, he said, is one reason for this development, while the import of bonded wood, mostly from Germany and Austria, is another. In the past, he explained, the sawmills processed predominantly raw wood from Switzerland. Today, this raw wood is frequently exported to foreign countries: "The amount of cutting is still about the same as in the past, however, given the growth rates of the forests, it should be more".

As far as alpine pastures are concerned, most of them are still owned by the Corporation and serve as an important addition to the fodder basis of many farms. The old phrase "Alpine farming is the backbone of Uri's agriculture" is still true today. When asked about the actual meaning of the phrase, Marianne and Wendelin Loretz, who run a farm in the lower valley and summer their animals in the upper Reuss valley, said that the Corporation-owned area they use makes up about one third of the total area they cultivate: "Perhaps there are other farms using more; like about one half. For the smaller, intensively working farms in the Urner Taloden, being provided with a large alp, it makes up more than one half'. 29

At the beginning of the twentieth century, the alps were at the heart of modernisation aspirations: a number of projects aiming at intensifying alpine farming were carried out. Many of them consisted of improving trails and the construction of new buildings (Furrer 1989). Soil improvement, such as drainage, also took place. After the middle of the century, at first the alpine pastures were only slowly affected by the structural change in mountain farming. The number of cattle in the canton was even growing, probably as a result of the use of imported fodder. By the end of the century, however, the number of cattle had declined, so that, increasingly, animals from outside the canton were summered on the alps owned by the Corporation. Furthermore, a lack of workforce and motorisation, that is, roads, required the electrification of alpine huts and the modernisation of the places of dairy processing. The stables had to be adjusted to the changed size of the animals as well as to stricter animal protection norms (Marti 1970). The polarisation of cultivation - areas that are easily accessible and cultivated are used more intensively, whereas the rest are used extensively or are abandoned - is less marked in Uri than in the neighbouring canton of Ticino, for example, but a growth in bush areas and woodlands in the summering area also needs to be noted (Amt für Landwirtschaft 2012). 
ROOM FOR MANOEUVRE AND STRATEGIES OF THE CORPORATION

How did the Korporation Uri deal with the economic dynamics to which its property is exposed? Moreover, how did it react to the accompanying shifts between political organisations? The second question has already been tackled in the first part of this section. Here it shall be emphasised once more that the forest section and the alpine section of the Corporation are organised in different ways. The woodlands are administered by the Korporationsbürgergemeinden, whereas the management plans are worked out by their forestries in cooperation with the canton's forestry board (Annen 2013). In 2000, the last so-called Verwaltungswaldungen, that is, forests cultivated by the Corporation, were abandoned. Still being the owner, the Corporation co-finances projects but is otherwise no longer active in the management of woodlands and no longer issues its own regulations. In an interview, Marty judged the situation as follows:

The woodlands are no longer a kind of commons as we know them in the original sense [...]. Still the Corporation owns most of the woodlands, but its forest regulations are almost not needed anymore. Due to the Federal Law on the Forest Police of 1876, the Corporation has lost its authority over the traditional distribution of exploitation rights. [...] Today, when it comes to the woodlands the Corporation is active only by way of contributions. It supports the Korporationsbürgergemeinden with fulfilling its task. [...] The Corporation co-funds but no longer has any influence on the forestry management.

The evaluation of the interviews allows for the conclusion that concerning the woodlands the Corporation has accepted its position as a paying owner, knowing that due to the proportions of its possession this position comes along with considerable negotiating power. This evaluation is in line with the argument of Beat Annen, the current head of the canton's forestry board, that regarding forest management, the actual structures represent a "favourable ownership situation". Eighty-six per cent of the woodlands are publicly owned, while 76 per cent are exclusively owned by the Corporation of Uri, he claimed.

The comparably small number of contact partners on the side of owners makes the implementation of concrete projects easier, provided that the forest owner is included in the strategic planning at an early stage. The forest owners are the canton's contract partners when it comes to implementing the agreed programmes. Being providers, they are not just the last link of the chain but the crucial element when it comes to implementing forest policy.

(Annen 2013)

In contrast to the woodlands, the Corporation is still relatively involved in the alps, both when it comes to administering and to issuing regulations. Consequently, 
the Corporation tries to maintain its room for manoeuvre in this field as much as possible and to be perceived as a real actor. It issues alp concepts and, when it comes to the funding of projects, it also makes allowance for farms that according to the state's national criteria for funding would no longer be funded. It aims to keep the number of alpine farmers as high as possible. On the one hand, in this way it ensures that citizens are aware of its activities and functions; on the other hand, doing so it provides for a larger workforce for the important maintenance of pastures. However, from the interviews it also becomes obvious that more than in the past, the Corporation considers itself as a neutral administrator. For example, Marianne and Wendelin Loretz, who summer animals, claimed that today the Corporation increasingly leaves consensus building to those cultivating the alps, such as when it comes to the borders between cattle and goat pastures:

WL: The Corporation gets involved only if called. If two farmers reach an agreement it doesn't say word. In the past this was somewhat different. Then the supervisor came and said, "The goats cannot be on this pasture. They must be taken off it". Even if the farmers had reached an agreement. [...] Today it is like this: no plaintiff, no judge.

It seems as if the Corporation takes care to adjust the framework conditions of the farmers to the general developments in agriculture by way of updated regulations and investments in infrastructure. At the same time, it aims to keep its administrative efforts reasonable. In contrast to the woodlands, where for a long time any decision-making about exploitation is dominated by external experts, when it comes to alpine farming it still has a large stock of experience and knowledge, allowing for adapting much more independently.

The extent to which the Corporation has adjusted its regulations to economic circumstances cannot be explained in detail here. The fact that it has frequently done so is demonstrated by an episode told by Josef Herder:

In the past, wood was a source of income for the Corporation. For each cubic metre of harvested or sold wood, one had to pay a fee. [...] Then, in February, 1990, there was Storm Vivian, which toppled large areas of woodlands. This was a considerable burden for the Korporationsbürgergemeinden and of course as a consequence the Corporation abandoned the fee. From then on, the Corporation had to pay for the woodlands.

From the aggregated yearly accounts of the Corporation, it becomes obvious that for slightly more than a century it succeeded despite relatively declining prices for forest and alp products, generating almost steady revenues from these two fields. In the second half of the century the licences for water power and quarrying replaced forestry and agriculture as the predominant sources of income. Without this increase in revenues it would have been impossible to pay the expenses for the woodlands and in particular for the increasing investments into the infrastructure of alpine farming and agriculture. 
Today the Corporation is in a sound financial situation (see Section 5.3). As the current accountant Ralph Lussi explained:

Looking at the yearly account and the financial position, on the whole the Corporation is in a pleasant situation. In the past few years, it has been possible to continuously improve our equity base. [...] Thus, the Corporation is well-off which, given the many tasks and its function as an important provider of funding, is important indeed, for there takes place a kind of redistribution of funds to the public. [...] The payouts to third parties (the canton, communities, private households and organisations) make up about one third of the total expenses. It is thus important that the Corporation is able to cope with some difficult years.

Thus, the Corporation's economic survival is safe for the foreseeable future, although a large share of its property has markedly lost in value. It becomes clear from the interviews that the financial reorientation of the Corporation has also inspired debate regarding its tasks. The debate is not on the question whether it should sell its woodlands or the alps as loss-making branches. It seems as if nobody denies that landed property is the foundation of the organisation. In the social and cultural realms, however, the Corporation's commitment is clearly less sound. Having contributed considerable funding to the extension of homes for elderly people in the canton in the 1980s and 1990s, in 2018 it withdrew from sponsoring the Rosenberg home for seniors in Altdorf. Moreover, according to some of the interviewees, until recently its commitment to the Kulturkloster in Altdorf was uncertain. Since the Capuchin monks moved out, this complex of buildings, located above Altdorf and visible from far away, has been extensively used as an event location, under the slogan "House of Silence" (see Figure 5.8).

Since March 2020, the Corporation has handed over the administration and running of the Kulturkloster to an association, supporting the latter by way of funding and is represented by three board members. In this case, the argument seems to have pushed through that social and cultural policies, although not belonging to the core business of the Corporation, are at the same time exactly those fields that are much more relevant for the majority of citizens than forestry and alpine farming.

In his interview, retired Corporation President Josef Herger explicitly supported the demand that in the future the Corporation should also support the elderly and the social infrastructure.

I'm not sure if the Corporation is right to operate in real estate. [...] We might as well raise the Bürgernutzen (citizens' benefit). In my opinion, the Corporation should increase its support of cheap flats for the elderly in peripheral regions. Then older people could stay in their homes longer. [...] But as yet they have been very reluctant to move into in this field. [...] The Corporation should identify more with these people. To increase citizens' awareness of the Corporation again, action is necessary. 




Figure 5.8 The Kulturkloster above Altdorf in a picture taken around 1880. After the separation of 1888 , the monastery became the property of the Corporation. Source: Staatsarchiv Uri. Photographer unknown.

Marty also expressed concerns about the possibility that, for the sake of revenues, the Corporation might withdraw from further fields of activity. He gave the Kulturkloster as an example:

It would be a disaster if the Corporation considered the Kloster only a loss-making business, if it sold it or leased it according to building law. I hope this won't happen, although there have been a number of voices speaking out in favour of it [...]. The building is part of the financial assets, thus it no longer has anything to do with administration or the tasks of the Corporation. And financial assets may be sold, which may perhaps be the best deal for the Corporation. One might sell it, one would no longer have to pay for maintenance, no longer would 2 million have to be invested for maintenance. [...] There are such voices. I do not believe this to be the direction into which the Corporation should move [...] I just think that these are matters that are important for the public: the Kloster is relevant for the landscape, it is a cultural building [...]. It should maintain its current nature. And if this comes along with expenses to be paid by the Corporation, well, then the Corporation should accept it to be in the red. But for such a decision we need a majority, and there must be the insight that the Corporation is needed there. Not under the financial aspect, but that it needs it for itself, for its future existence. This is just one example. There are others. [...]. If such examples appear [...] there should be awareness that it [the Corporation] should not reduce its field of tasks. That it 
should at least maintain and, if possible, enlarge it. Although this will not always make money.

Thus, the Korporation Uri - like many other corporations in Switzerland faces the question of what kind of mix of farmers' collective, corporation for non-profit, cultural activities and commercial real estate owner it would like to implement (see Niederer 1991 in Chapter 2). Thus, it faces the challenge of connecting its tasks to one another, of integrating them.

No matter how the Corporation comes to develop its fields of activity, its natural resources will still characterise its profile as a corporation: as a property and asset base, as a good that must be maintained and preserved, as a label and a bargaining chip in its negotiations with other organisations. In this context, in view of the future, it is particularly interesting as to how the Corporation will cope with sustainable utilisation in the context of economic and social change. To what extent will its administrative and utilisation practices be influenced by debates and political action in the tension area between the loss of biodiversity, the depopulation of mountain valleys, subsidies for agriculture, the recreation requirements of an urban population and so forth? In what ways will these influences modify the organisation's view of its natural resources?

\section{Notes}

1 These facts and figures are according to Lisag AG in Altdorf, Amt für Landwirtschaft des Kantons Uri and Korporation Uri.

2 Summering farms are administrative units entitled to receive a variety of contributions from the state. The local organisation of work and pastures is not necessarily the same as these units.

3 Some summering farms on private alps partly cultivate lands of the Corporation. They are also filed under Corporation alps.

4 See Figure 5.8.

5 A former military bunker purchased by the Corporation and now used for growing mushrooms.

6 On the SNEE contract, see the section headed 'The Korporation Uri as an element of the canton's political structure in the twentieth and twenty-first centuries'. The contract also guarantees the Corporations shares of licences to be granted by the canton for a power station which currently is in the planning process.

7 For most quarries the Corporation grants a licence both for quarrying and for using it as a dump, because in most cases part of the quarry is already used as a dump while in the other parts stones are still quarried. When the quarrying reaches the licensed limits, the quarry is filled up again and re-vegetated. From then on it no longer generates any regular income for the Corporation. Only in very rare cases is a dump established at a place that has not previously been used as a quarry. Due to this double use, the seven licences for quarrying and dumping have been granted for only four locations (see Figure 5.3).

8 Anyone who summers animals on the alpine property of the Corporation must pay a grazing fee, the so-called Viehauflag.

9 The territory of historical Unterwalden covers today's cantons of Obwalden and Nidwalden.

10 As examples, see the agreements of 1350 and 1356 between Uri and Schwyz concerning alps (Denier 1886). 
11 As an example, see the decision of 1365 concerning the "Grenzen und Marken des Holz- und Weidrechts der Kirchgenossen auf Seelisberg" (Denier 1886).

12 As an example, see the decision of Altdorf of 1366 about woodcutting in a forest (Denier 1886). Other examples from the fourteenth and fifteenth centuries can be found in Denier 1887, 1888 and 1889.

13 As an example, see the agreements by the valley people of Ursern of 1363 concerning the driving of cattle to alps and grazing (Denier 1886).

14 See Chapter 2.

15 "Vorschläge der vom Bezirksrat von Uri gewählten Kommission für Vorberatung der Allmendbenutzungsfrage", Altdorf, 22 May 1852, KA A 13/11-1 (2).

16 Urner Volksblatt of 5.2.1887.

17 This section refers to an article on the history of the Corporation since 1888: Wunderli 2020.

18 Since 2015, the Corporation Chancellery rather than the Korporationsbürgergemeinden has run a central register of citizens, linked to the data of the local residents' registration offices. This re-organisation has resulted in the data being cleaned and in a reduction in the number of citizens.

19 At the 2019 Korporationsgemeinde, the previous way of paying the citizens' benefit in cash (5 CHF) was extended by a system allowing the organisation to hand out vouchers to its citizens. This has made the use of offers by regional providers such as those of cable cars or of shipping companies cheaper.

20 Interview with Pius Zgraggen, 07.06.2017.

21 Interview with Karl Marty, 24.01.2018.

22 Urner Volksblatt, 02.02.1889.

23 Cantonal constitution of 1888, Art. 34: "The commons as well as all other property of the corporations are separated to the two commoners' organisations of Uri and Ursern as pure corporation property, without any claims by the state. The two corporations organise themselves at their own discretion. Still reserved is the state's right to supervise their organisational and administrative rights and obligations".

24 Cantonal constitution of 1984, Art. 72-74: "The Korporationen Uri and Ursern are independent corporations under public law. [...] The property of the corporations is guaranteed. The corporations support the canton and the municipalities with fulfilling their tasks and help with achieving the national goals".

25 Interview with Franz Dittli and Ralph Lussi, 20.07.2018.

26 Alternative. Die andere Urner Zeitung, No. 81, 1983.

27 Neue Urner Zeitung, 03.05.1997.

28 "In the past" probably refers to the second half of the twentieth century, when Josef Herger was active in this profession. In 1927, then Senior Forestry Official, Max Oechslin listed 31 sawmills in Uri (Oechslin 1927).

29 Interview with Marianne and Wendelin Loretz, 29.01.2018.

\section{References}

Amt für Landwirtschaft, Kanton Uri (2012) Überprüfung der Landwirtschaftspolitik im Kanton Uri. Altdorf: Amt für Landwirtschaft, Kanton Uri.

Annen, B. (2013) Urner Wald - Grundlage für eine nachhaltige Entwicklung, Schweizerische Zeitschrift für Forstwesen, vol. 164, no 8, pp. 220-224.

Arnold, G. (1990) Die Korporation Ursern. Ein Beitrag zum urnerischen Staats- und Verwaltungsrecht. Altdorf: n.p.

Arnold, P. (1994) Almosen und Allmenden. Verarmung und Rückständigkeit in der Urner Markgenossenschaft 1798-1848. Zürich: Chronos. 
Bielmann, J. (1972) Die Lebensverhältnisse im Urnerland während des 18. und zu Beginn des 19. Jh. Basel/Stuttgart: Helbing und Lichtenhahn.

Bigger, E. (1949) Das Prinzip der Trennung der Gewalten im Kanton Uri. Zürich: n.p.

Bloetzer, G. (1973) Das Holzrecht von Riemenstalden. Untersuchung über die rechtssystematische Stellung und den geltenden Inhalt eines von den alten Orten Uri und Schwyz im Zusammenhang mit dem Grenzvertrag von 1350 vereinbarten Nutzungsrechtes. Zürich: ETH- Zürich.

Brändli, P. (1986) Mittelalterliche Grenzstreitigkeiten im Alpenraum, Mitteilungen des historischen Vereins des Kantons Schwyz, vol. 78, pp. 19-188.

Bricker, E. (2018) Das Sumpfland seinem „ungünstigen Zustand" entrissen. Die Entstehungsgeschichten der rechtsseitigen (1916-1925) und der linksseitigen Melioration (1942-1945) in der Urner Reussebene sowie deren Auswirkungen. Bern: Masterarbeit am Historischen Institut der Universität Bern.

Denier, A. (1886-1889) Urkunden aus Uri, Der Geschichtsfreund, vol. 31-40, 41, 42, 43.

Furrer, B. (1989) Wandlungsprozesse in der Kulturlandschaft der Alpen Uris im Spiegel der Gebäude. Zürich: n.p.

Gemeinnützige Gesellschaft Uri (1884) Bericht über die Inspektion der Urner-Alpen. Altdorf: n.p.

Glauser, F. (1988) Von alpiner Landwirtschaft beidseits des St. Gotthards 1000-1350, Der Geschichtsfreund, vol. 141, pp. 5-173.

Huber, K. (1911) Die Allmendgenossenschaft Korporation Uri in ihrem Verhältnis zum Kanton und $z u$ den Gemeinden. Beromünster: n.p.

Kälin, U. (1991) Die Urner Magistratenfamilien. Herrschaft, ökonomische Lage und Lebensstile einer ländlichen Oberschicht 1700-1850. Zürich: Chronos.

Kälin, U. (2004) Freiheit im politischen System des alten Uri, Historisches Neujahrsblatt / Historischer Verein Uri, vol. 95, pp. 25-36.

Landolt, O. (2008a) Wald und Holz in der Zentralschweiz im Wandel der Zeit: Einleitende Bemerkungen, Der Geschichtsfreund, vol. 161, pp. 7-20.

Landolt, O. (2008b) Mittelalterliche Grenzstreitigkeiten im Alpenraum: schwyzerischurnerische Konflikte im Riemenstaldnertal, Mitteilungen des historischen Vereins des Kantons Schwyz, vol. 100, pp. 200-203.

Marchal, G. (1990) Die "Alten Eidgenossen" im Wandel der Zeit, in Innerschweiz und frühe Eidgenossenschaft. Olten: Walter Verlag, pp. 309-403.

Marti, E. (1970) Die Land- und Alpwirtschaft im Kanton Uri. Schweizerischer Alpkataster. Bern: Abteilung für Landwirtschaft.

Marty, A. (1951) Die Viehwirtschaft der Urschweiz und Luzerns, insbesondere der Welschlandhandel 1500-1798. Zürich: Europa Verlag.

Nager, F. (1926) Die Landsgemeinde von Uri in rechtshistorischer Entwicklung, Historisches Neujahrsblatt / Historischer Verein Uri, vol. 32, pp. 3-77.

Oechslin, M. (1927) Die Wald- und Wirtschaftsverhältnisse im Kanton Uri. Bern: H. Huber.

Püntener, A. (1909) Bericht über die Alpen-Inspektion in der Korporation Uri, 1905-1908. Altdorf: n.p.

Sablonier, R. (1990) Innerschweizer Gesellschaft im 14. Jahrhundert. Sozialstruktur und Wirtschaft, in Innerschweiz und frühe Eidgenossenschaft. Olten: Walter Verlag, pp. 9-233.

Sablonier, R. (2008) Gründungszeit ohne Eidgenossen. Politik und Gesellschaft in der Innerschweiz um 1300. Baden: hier und jetzt.

Sauter, M. (2017) Die Kunstdenkmäler des Kantons Uri. Schächental und unteres Reusstal. Bern: Gesellschaft für Schweizerische Kunstgeschichte GSK. 


\section{Rahel Wunderli}

Spycher, L. (2018) Die Korporation Uri - Allmendverwaltung im Wandel. Schweizer Agrarpolitik und deren Einfluss auf die Verwaltung einer kommunalen Alpweide. Bern: Masterarbeit am Institut für Sozialanthropologie.

Stadler-Planzer, H. (1971) Die Ausscheidung der Bezirke Uri und Ursern aus dem Staatsverbande anlässlich der KV-Revision 1887/88, Der Geschichtsfreund, vol. 124, pp. 358-372.

Stadler-Planzer, H. (1980) Die Behörden- und Verwaltungsorganisation Uris: ein Überblick, Der Geschichtsfreund, vol. 133, pp. 35-82.

Stadler-Planzer, H. (1993) Geschichte des Landes Uri. Von den Anfängen bis zur Neuzeit. Schattdorf: Uranos Verlag.

Stadler-Planzer, H. (2015a) Geschichte des Landes Uri. Frühe Neuzeit. Schattdorf: Uranos Verlag.

Stadler-Planzer, H. (2015b) Geschichte des Landes Uri. Von der helvetischen Umwälzung in die Gegenwart. Schattdorf: Uranos Verlag.

Stadler-Planzer, H. et al. (2013) Korporation Uri. Altdorf: Korporation Uri.

Stuber, M., Bürgi, M. (2011) Hüeterbueb und Heitisträhl. Traditionelle Formen der Waldnutzung in der Schweiz 1800 bis 2000. Bern: Haupt.

Viallon, X.-F. Liechti, K., Stuber, M., and Wunderli, R. 2019. Vermittlung, Einbau, Komplementarität - Formen des staatlichen Zugriffs auf kollektive Weiden und Wälder in der Schweiz im späten 19. Jahrhundert. In Head-König, A.-L., Lorenzetti, L., Stuber, M., and Wunderli, R. (eds) Kollektive Weiden und Wälder. Ökonomie, Partizipation, Nachhaltigkeit, pp. 125-149. Zürich: Chronos.

Weber, A. (1952) Die rechtliche Stellung der Korporation Uri im Kanton. Bern: Academic publication.

Wunderli, R. (2016) Berglandwirtschaft im Strukturwandel. Bauern/Bäuerinnen aus Ursern (UR) und politische Institutionen während der zweiten Hälfte des 20. Jahrhunderts. Altdorf: Gisler Medien.

Wunderli, R. (2020) Eine Institution als Kaleidoskop: Die Korporation Uri seit 1888, Historisches Neujahrsblatt / Historischer Verein Uri, vol. 74, pp. 9-47.

Z'graggen, H. (1999) Die Auseinandersetzung um die politische Gleichberechtigung der Frauen in Uri bis zur ersten eidgenössischen Abstimmung über das Frauenstimm- und Wahlrecht 1959. Bern: Seminararbeit am historischen Institut.

Zurfluh, C. (1993) "Leidenschaftslos, freimüthig und loyal": das Urner Pressewesen und seine Bedeutung für die Urner Politik von der Helvetik bis zum Ersten Weltkrieg. Altdorf: Zurfluh. 


\title{
6 Urban commons in Alpine areas
}

\author{
The case of the Bürgergemeinde \\ Chur (Canton Grisons)
}

\author{
Martin Stuber
}

\subsection{Introduction}

The Alpine city of Chur demonstrates a particular phenomenon of Swiss Gemeindedualismus (municipal dualism): From the Late Middle Ages until today the forests and pastures were owned by the citizenry, the later Bürgergemeinde (Corporation of Citizens), but from the late nineteenth century their utilisation has been a matter for the Politische Gemeinde (municipality of residents).

\section{The Bürgergemeinde Chur today}

Chur is the capital of the Canton of Graubünden (Grisons), and with 37,687 inhabitants is the sixteenth largest city in Switzerland. ${ }^{1}$ This Alpine city is located at the entrance to the Schanfigg in the broad valley of the Alpine Rhine. It is the starting point of several mountain passes, which makes it a natural traffic hub, traditionally functioning as an important place of transit trade. Its topography is characterised by the river Plessur which cuts through the city and forms an alluvial fan, until it flows into the Rhine. A 35-metre-high rock rises from the alluvial plain, on which is the Bishop's seat. The territory of the city has its lowest point at 554 metres above sea level; the mountain slopes rise up to 1,885 metres above sea level. These steep slopes are mostly wooded and serve as protective forests. No less than $54 \%$ of the entire territory is woodlands; another $16 \%$ is used for agriculture.

As in most places in the Canton Grisons, there is a Bürgergemeinde (Corporation of Citizens) in Chur in the form of a corporation under public law, additional to the Politische Gemeinde (municipality of residents). About $15 \%$ of the inhabitants are members of the Corporation of Citizens. Its highest authority includes some 5,755 citizens who elect the 9 members of the Bürgerrat (Citizens Council, including the Mayor and Deputy Mayor), and the Audit Commission every four years. The administrative team, headed by the Scribe of the Citizens' Council is in charge of the operative business. There are special commissions for specific topics, consisting of four to six elected citizens, the most important of which are the Domains Commission, the Naturalisation Commission, the Budget Commission and the Commission in charge of 
running the Bürgerheim (home for elderly people), and there are also the two Inspectors of the Gemeindegüter (full properties of the Corporation) The link between the authorities and the citizenry is the Bürgerverein (Association of Citizens), which has more than 2,100 members. When there are elections or other votes, the Bürgerverein organises general meetings to inform about and nominate the people who will run for office, and to decide about slogans. It furthermore organises cultural and social events.

The landed property of the Corporation of Citizens covers 4,212 ha and goes beyond the territory of Chur. More than $60 \%$ of the Corporation's lands are in other municipalities, particularly in Arosa (2,221 ha), which is about 25 kilometres away. Of the Chur territory 1,593 ha are owned by the Corporation of Citizens, comprising $57 \%$ of the 2,810 ha of the total area of the city. There are 18 farmers in Chur, and 11 lease their land from the Corporation of Citizens. The agricultural holdings of Chur include nine alps with more than 2,000 ha of pastures. These are also owned by the Corporation of Citizens, such as a number of Maiensässe (a particular kind of alp) which serve as seasonal pastures in spring and autumn. Leasing is via the Bauerngenossenschaft, as the organisation of Chur farmers, which elects one Alpmeister (alpine supervisor) for each alp, who then appoints a herdsman for that alp. The four cattle alps of Maran, Sattel, Carmenna and Prätsch in the region of Arosa accommodate 400 cattle, producing about $400,000 \mathrm{~kg}$ of alpine milk per summer. This allows the dairy of Maran, which the Corporation has leased to the Farmers' Cooperative and which is connected to the four cattle alps by a pipeline, to produce more than 35 tons of Alpine Cheese. Another 400 cattle, mother cows and calves, spend the Alpine summer on the young cattle alps of Campadiel, Wolfboden and Ochsenalp in the back part of the Schanfigg, La Motta at Mormorera and Starschagns at Oberhalbstein. Chur is closely connected to Arosa and is developed as a tourist place. Large parts of this well-known tourist destination have been built on property formerly owned by Chur, and two-thirds of the ski area are on the Chur Alpine pastures. (see Figure 6.1)

Only $5 \%$ of the property owned by the Bürgergemeinde (206 ha) is Gemeindegut (full property of the Corporation), which the Corporation has the exclusive right to use, as its historical origin is the Bürgergut (property of the full citizens) and the Armengut (property for the poor); today these are leased agricultural land as well as Baurechtvergaben, which means agreements on building rights, which grant the utilisation rights for a plot for a certain time against payment of a certain interest rate while the estate owner retains ownership. The Bürgergemeinde generates its main income in this way, to finance its social and cultural commitment to the City of Chur.

Of $95 \%$ of the property owned by the Bürgergemeinde (3,986 ha), on the other hand, the Corporation holds only property rights, but the administration is carried out by the municipality and the revenues flows into the municipality's finances. Accordingly, the Department of Building, Planning and Environment, which includes the section Wald und Alpen (woodlands and alps) of the Grünund Werkbetrieb (Green Spaces and Maintenance Office), is in charge of their 


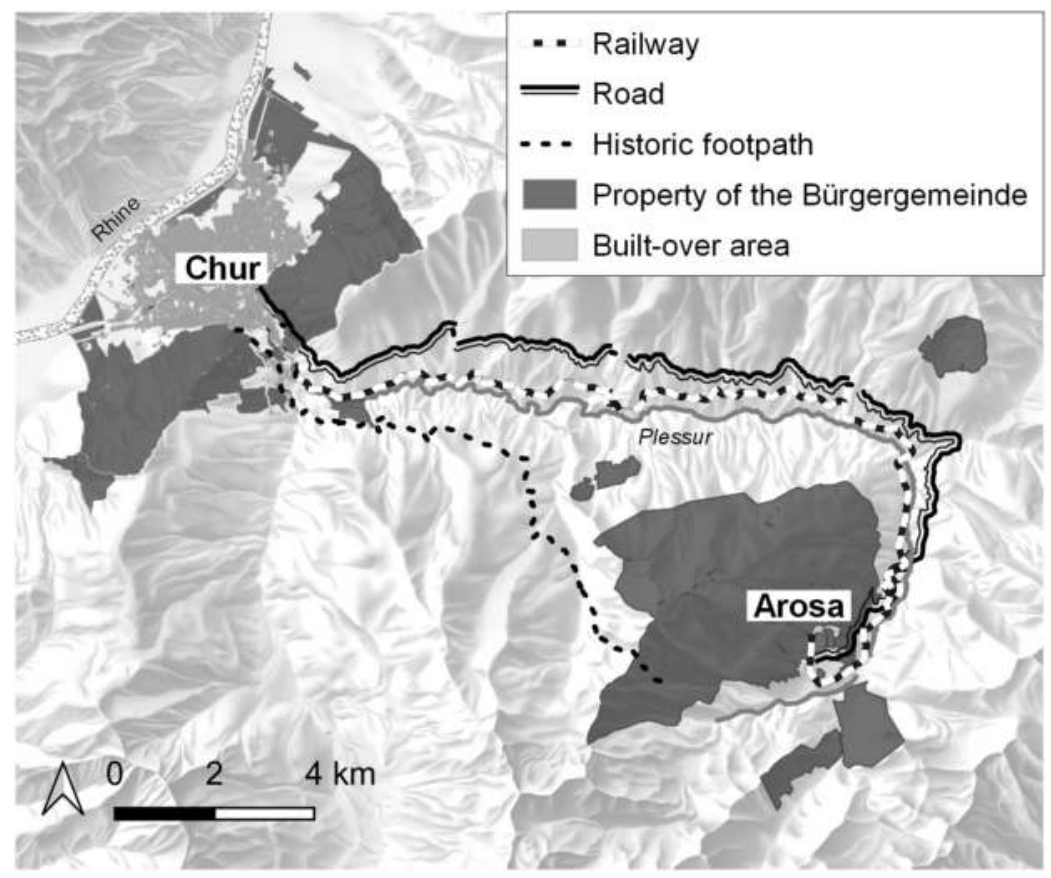

Figure 6.1 Map of the landed property of the Bürgergemeinde Chur today, including the Chur Alpine pastures at Arosa, in about 2018. Map compilation and design by Sarah Baumgartner, University of Bern; geodata source: Amtliche Vermessung (AV), Kanton Graubünden, 2020; hillshade: Relief PK50, reproduced with permission of Swisstopo (BA20043).

administration. They are supported by the Alps Commission, which consists of five members elected by the Gemeinderat (Municipal Council). According to the Alps Law of 2005, these members represent the different positions of Chur's alpine farming: the Corporation of Citizens has at least one representative, there is a representative for the municipal administrative section of the Wald und Alpen and one for the Bauerngenossenschaft (Farmers' Cooperative). Apart from providing Realersatz (purchase of new land as a real replacement for the land sold), the so-called Bodenerlöskonto (Land Revenue Account), into which most of the revenue from estate sold by the Corporation at Arosa is placed, serves most of all for improving the Alpine pastures, which in each case requires a joint decision by the Bürgergemeinde and the Politische Gemeinde. ${ }^{2}$

\section{Approach, research literature and sources}

Our starting point is a finding formulated in an important European comparative edited volume on Rural Commons (Grüne et al. 2016): in the longue durée 
and particularly in the course of political, legal and economic transformations, common property underwent extremely different developments, from being dissolved to being integrated into the (post-) industrial structures of economy and constitution. In this context, changes in the utilisation of woodlands and pastures must preferably be interpreted as depending on multiple factors. The formerly predominant, purely demographic, patterns of interpretation, which assumed that the sustainability of the areas was determined by the natural space, must be replaced by socio-economic explanations, and completed by local and regional power constellations. One crucial initial factor, however, is the topography. The common property still existing today mostly consists of areas where the soil was less suitable for intensive farming, and which, according to Thünen's model of land utilisation, were located on the outer, unprofitable fringes of the spaces.

When considering the historical effect of topography, a longue durée perspective must be assumed, in order to examine the various transformations of the Chur citizenry and its way of exploiting resources. This long-term approach is in line with the way in which the actors under analysis understand themselves. Bürgerrat and President of the Bürgerverein, Martin Studer, explains: 'To judge what is done today, one must take a brief look into the rear-view mirror, to see what it was like in the past. And of course we are proud to say that the Corporation of Citizens is older than the Politische Gemeinde. ${ }^{3}$ In this historical way of understanding oneself it is of interest that the citizenry has always attempted to bring the consciousness of tradition together with adaptability. A former member of the Citizens' Council, Ruth Bianchi, identifies this combination as the secret of the success of the Corporation of Citizens: 'After all, the whole thing is running like a river, with new water coming and old water running downstream ... If only the tradition is continued and nothing is added, this isn't good.'

Any long-term analysis of the Chur citizenry and their resources starts from a rich yet heterogeneous state of research. The history of the Corporation of Citizens is described in an overview by Enrico Giacometti which sheds some light on all essential aspects since the beginning of the municipal dualism (1875) (Giacometti 1999). Extensions and differentiations are to be found in the voluminous dissertation thesis by Simon Bundi who not only reconstructs for Chur the citizenry's political conflicts with the Niedergelassenen (residents) and later with the Politische Gemeinde (municipality), but also embeds them in the appropriate conflicts at Canton level (Bundi 2016). The Handbuch der Bündner Geschichte (2000) gives a comprehensive overview of the Canton context, however only rarely referring to the municipal dualism. This gap is only partly filled by a short edited volume on the development of the Grisons communities from the Late Middle Ages until today (Hitz, Rathgeb and Risi 2011). The two-volume history of Chur provides both rich and differentiated information concerning the development of the citizenry and their commons from the Late Middle Ages until the end of the guilds regime in the midnineteenth century (Jecklin 1993). Schorta (1942) reconstructed the Chur 
commons in the Late Middle Ages, and the Churer Stadtbuch gives some brief historical descriptions of Chur's forests, the Chur Alps and the Constitution of the City (Mohr 1953, Pieth 1953, Waldungen 1953). The state of research is consolidated by a more recent historical analysis of the city's spatial development (Fuchs 2011) and of the guilds regime (Wendler 2015, Wendler 2018). Stimulating in the Swiss comparison are analyses of the land policy at Chur in the second half of the twentieth century (Buchmann 1977, Gerber 2008). Embedding the citizenry's alpine farming and land policy at Arosa may rest on local history works which, however, only cover the period until the first third of the twentieth century (Just 1907, Maron 1934, Casti 1971). In the context of the SCALES project there are two exam papers from the field of social anthropology on today's collective cultivation of the Chur Alpine pastures (Stoinescu 2018, Andermatt, Freiburghaus and Koch 2019) as well as three historical analyses about the Corporation of Citizens since the nineteenth century, of the financial development, of the administration of the Gemeindegüter and of the land policy in the city (Brändli 2019, Moll 2020, Plüss 2020).

The Staatsarchiv des Kantons Graubünden, the Stadtarchiv and the Archiv der Bürgergemeinde provide an extraordinarily satisfying number of sources. For pragmatic reasons, printed sources were used first. This includes laws and decrees, as well as their drafts, reports by the administration to the Corporation of Citizens ${ }^{5}$ and the municipality, ${ }^{6}$ reports by the Canton's forest and alps administration, announcements and official statements by the authorities, forestry plans, as well as a number of printed publications from public discourse. Several local and regional newspapers were examined for specific periods for relevant topics, and most systematically the Aroser Zeitung and the Bündner Tagblatt. In addition to the written sources, six extensive oral history interviews were conducted with important actors of the Corporation of Citizens and the Chur municipality. These expert interviews on the more recent past and the current situation of the Corporation of Citizens were conducted in accordance with the jointly determined interview guidelines of the SCALES project, and have been transcribed in their entirety.

\subsection{Transformation of the Corporation}

The Chur citizenry looks back on a long history. In the course of emancipation from the Bishop, in the Late Middle Ages there developed the community. By the mid-fifteenth century it had consolidated to the guilds regime which lasted for almost four centuries. With the abandoning of the guild constitution, in 1840 there started a period of transformation characterised by conflict between citizens and residents. In 1875 this resulted in a new constitution for the city which, complementarily to the Politische Gemeinde (municipality of residents), constituted a Bürgergemeinde (Corporation of Citizens). Subsequently and to this day, the Corporation of Citizens has worked out its new role in the context of the municipal dualism in the twentieth century. 


\section{Emancipation from the Bishop in the Late Middle Ages}

The topographic and constitutional starting point dates back to the fifth century. Since then Chur has been characterised by the classical dualism of the Bishop's residency and the market settlement below. The latter had moved from the Roman vicus of the 'Welschdörfli' on the left bank of the Plessur to the area immediately below the rocky plateau where the Bishop's court had been established. The full development into the Bishop's rule of the city was based on the privileges (e.g. market rights) granted by Emperor Otto I. in the second half of the tenth century. The background was the Ottonians' Imperial and Church policy, who made the bishops their most important supporters in the Empire and made them the sole rulers of cities (Bühler 1993a: 220-223, Fuchs 2011: 17-18).

Concrete indications of the formation of a community of citizens date from the thirteenth century, when for the first time the sources used phrases such as 'universi cives Curienses' (1227) or 'cives et consules' (1282). The developing organisation of the citizenry was still highly dependent on the Bishop, however. More influence for the citizenry resulted from the organisation of watch duty and the building of a city wall. The population of Chur, which in the thirteenth century was 1,000-1,500 people, consisted mostly of farming citizens, craftsmen and tradesmen benefitting from the lively building activities and Chur's favourable geographic location. The political emancipation of the citizenry developed fully from the late fourteenth century on. The first city statutes were created between 1368 and 1376. In a number of episcopal cities such developments ended with the city lord being expulsed, such as in Basel and Lausanne. In Chur the Hof (court) was not completely incorporated into the city, which was not least due to the particular topographic location of the Bishop's residency (Bühler 1993b: 229-232, 250, Bundi 1993a: 266, Fuchs 2011: 22-23, Bühler 2015).

The emancipation of the Chur citizenry is embedded in the general movement of communalisation which arose in Late Middle Ages in the territory of Grisons. In the beginning neighbourhoods developed (vicinitas, vicinantia, vischnaunca) as groups of households, settling close to each other. The purpose of such associations was to peacefully organise the commons as a resource, that is, woodland, pasture and water, which was becoming scarcer, and to pass village statutes for this: in the form of alp and meadow statutes, and provisions about fences, walls, ditches, troughs and farm lanes. In the Bishopric of Chur the communal movement resulted in a corporative constitution. Under the name Gotteshausbund, in 1367 a representation of the estates developed which was characterised by a particular feature wherein, apart from nobility and clergy, citizens and peasants were also represented in the form of communities. Constitutional principles were fixed as we know them from the Magna Carta libertatum in England (1215): no administrator of the Bishopric was allowed to take office without the consent of the estates, real estate owned by the Bishopric was not allowed to be sold without their consent, the safety of castles 
and thus the defence of the country were to be funded from the Bishopric's revenue and only in urgent cases would the country help by way of a tax it would levy (Bundi 1993b: 356-358, Sablonier 2000, Blickle 2011: 16-18).

\section{Exclusive guilds regime in the Early Modern Period}

Installing the regime of the guilds was a crucial step in the emancipation of the citizenry, and provided the foundation of Chur's political, economic and social life for almost four centuries. The immediate starting point was the conflagration of April 27th, 1464, which destroyed most parts of the city, including the City Hall and the liberty charters. Chur sent his Scribe to Emperor Frederick III. in Vienna. This enterprise was successful. On July 8th, 1464, the Emperor issued a document which - in addition to confirming the liberties granted by him - allowed the citizenry the right to appoint a Mayor and the Council members, as well as to found guilds. Just one year later the Chur citizenry consolidated its extended self-organisation by way of the Zunftverfassung (Constitution of the Guilds) (1465). ${ }^{7}$ All professions were incorporated into the five guilds of Rebleute (wine growers), Schuhmacher (shoemakers), Schneider (tailors), Schmiede (smiths) and Pfister (bakers). This provided the basis for the numerous guild statutes and decrees which were formulated according to the needs of the individual branches. Throughout the entire Early Modern Period Chur's economy moved most of all within the narrow frame of the guilds regime. In a city characterised by agriculture, the landowners from the Guild of Wine Growers as well as the Säumer (pack animal drivers) of the Guild of the Smiths, who participated in transit traffic, were highly influential. Accordingly, the Transport Statutes of the Guild of the Smiths (1592) regulated the entire transport business, which was economically very important for the city.

Beyond the realm of handicraft, the Zunftverfassung served as a city constitution, and the community met in the form of guild assemblies. Each guild elected eleven of their guild members to the Council, and they also elected a Zunftmeister (Guild Master) who was in charge of deciding on inner-guild matters. The Elfer (Eleven) from all guilds together formed the Extended Council. The fifteen members of the Small Council were elected by the Mayor, the Small Council and the Extended Council from the ranks of the Eleven, and together with the five Guild Masters they formed the Extended Small Council. Together with the Extended Council and the incumbent Mayor, the Extended Small Council appointed the new Mayor. This complicated election procedure, which here is given in a somewhat simplified way, shows how, generally, both urban regulations and those meant only for the guilds blended into each other. The Zunftverfassung provided the foundation on which the urban administration and the city's law were built. The path to membership of the two Councils, the Mayor's chair, and to other positions in the city was exclusively via the guilds. At the same time, however, the Mayor, the two Councils and the law court were superior to the guilds. The historian Uwe Wendler, the archivist of Chur and the foremost expert 


\section{Martin Stuber}

of the guilds regime, concluded that the complexity of the system reflected the well-balanced power relations in the city, reserving important positions for certain circles among the citizenry and keeping other groups away: 'For the community was at best in theory but not at all in reality a community of people with equal rights, although the Guilds Constitution attempted to give this impression' (Wendler 2018: 41, Jecklin 1993a: 303, 314, Bundi 1993c: 462-464, Fuchs 2011: 44, Bundi 2015).

From the sixteenth century on it became apparent in Chur, as in other cities, that access to exclusive citizenship was distinguished by raising the prices to be paid for it, or by temporarily blocking it completely, and thus permanently limiting the other inhabitants of the city to a minor status. In the seventeenth century, only half of the population in Chur counted as full citizens. By the end of the eighteenth century, of the 3,442 people living in the city just 937 that is, about one quarter - were full citizens.

Apart from the citizens, a great number of Hintersassen (socmen) lived in Chur without citizenship. They had no access to political positions and were allowed to make use of the commons land only in a very limited way. If the guilds had granted them the right to work with a craft, they had to pay a regular fee (guild's shilling), but they had no say concerning craft or guild matters. Taxable socmen at least had a temporary residence permit, but this was conditional on behaving well, and a minor violation of the laws could mean losing their residence permit for good. Among this group, which in the eighteenth century constantly numbered about 300 households, there were specialists such as armourers, pharmacists and even aristocrats who had come to the city as Huguenot refugees. The ungestürten Hintersassen (non-taxable socmen) held even more minor status, had only temporary residence permits, worked mainly as day labourers and were each accepted or sent away according to the interests of the citizenry. The citizenry's relationship with the Hintersassen was ambivalent: on the one hand, the citizenry craftsmen always feared the socmen as competitors, on the other hand the citizens could not do without the socmen, who bought their craft products, took over some of the watch duties, paid taxes and did inconvenient work.(see Figure 6.2)

Processes of exclusion targeted not only the socmen but even full citizens, as a few families increasingly monopolised access to the Council and other high positions. This restriction was not simply accepted, as demonstrated by a memorandum, for example, which in 1728 was handed in to the authorities by the majority of the citizens: in order to abolish corruption and clientelism in the context of elections, they demanded that ballots be secret in the future. The introduction of the Klag- or Schmähsonntag (Grievance or Defamation Sunday), which was introduced by proposal of the Guild of Winegrowers in 1737, also increased the permeability of citizenry and authorities. Now, guild assemblies were held one week before elections, where each individual could present their complaints and wishes, as far as they referred to the administration, and to the Guild Master who had then to present them to the authorities for deliberation, without giving the name of the claimant. Over the years 




Figure 6.2 View of Chur from Haldensteiner Berg, taken by Johann Aschmann at about 1780. Stadtarchiv Chur, G I_1.0004.119.

this developed into common law which was respected and tolerated by the authorities, but was never fixed in writing or adopted as city law. The Sunday before the annual elections served as a kind of wailing wall for all guild members who could not participate in government, as an opportunity to let out all their built-up anger towards the Council and the law court, and as an opportunity to vent grievances and make their own suggestions. The most frequent demand was to send away the socmen - who competed with the fullcitizenship craftsmen - but also revisions of the city law were requested, and proposals for establishing an orphanage, a library or for financial recovery were made. The Council did not consider such complaints binding, however. After the guilds had several times complained about the Council not supporting their claims, the Council reacted in 1752 with a sharp written response, pointing out that, first, the unlimited exploitation of the woodlands, as demanded by the citizens, would be possible only at the expense of future generations and would furthermore inevitably result in landslides (see Section 6.3), and that, second, it was the citizenry itself which prevented any solution for the socmen problem (Bundi 1993a: 289-292, Jecklin 1993a: S. 316-318, Jecklin 1993b: 122-128, 136-144, Hilfiker 1993: 22-28, 58-59, Fuchs 2011: 34, 42, Bundi 2015, Hilfiker 2015). 


\section{Martin Stuber}

\section{From exclusion to municipal dualism in the nineteenth century}

The invasion by the French as well as the Helvetic Revolution marked the end of the Ancien Régime (see Chapter 2). During the French occupation (for the first time in 1799), Chur was governed by a municipality government which abandoned any Zunftzwang (guild coercion). The Mediation of 1803 provided the guilds with political power again, but the old crafts privileges were limited. In spring 1804, the outrage of the craftsmen resulted in acts of violence. Two foreign carpenters had their tools smashed, the shops of some butchers were broken and meat was carried away. Only after intervention by the Canton authorities, to which the victims had turned, did the Council ensure that the stolen goods were returned. The guild coercion was also loosened in the Chur Trade Statutes of 1814, so that it allowed any Swiss (and French) citizen to settle in Chur and pursue a trade there. Apart from the crafts and trade statutes, however, the entire Guilds Constitution was subject to increasing criticism. There were complaints about the nonseparation of powers, the sluggish administration and voting by guilds instead of by citizens. The ferocity of the struggle becomes obvious from the conflict about a paper against the Guilds Constitution, published anonymously in 1838, where the latter was called inappropriate: 'But still your shrinking citizenry is wearing the traditional armour of the constitution, out of which your shrunken cheeks and dying eyes are staring, to - be frightened by themselves.' The Chur citizen, who was later identified as Ludwig Christ, particularly demanded the abandonment of the indirect election system in favour of secret ballot at a general assembly of the citizens. He refuted the arguments of the opponents by pointing out appropriate historical experiences in Switzerland:

For centuries, in other valleys of Switzerland thousands of people assemble every year, to peacefully and orderly elect their authorities, and the 300 citizens you have tamed, jammed and taught to be obedient, actually slaughtered, for so long, are not supposed to come together and elect someone without the danger of high treason and blood and thunder? ${ }^{8}$

The attacked supporters of the Guilds Constitution responded in a similarly fierce way and declared the 'suspicions and accusations to be found in the diatribe nothing more than vicious and bold lies' (Metz 1991, Jecklin 1993b).

With the Constitution of the City of Chur (1840), the guilds lost both their political and commercial significance $(\mathbb{S} 14)$. Apart from this fundamental change, however, the city's new constitution still included the Klag- und Schmähsonntag, which had been so important in the guild regime as an opportunity to let out suppressed anger, and has now been enshrined in written form for the first time: 'Any citizen may at any time present the authority with their desires, complaints or motions concerning public issues [...] The authorities will discuss them and present the next citizens' assembly with the results' $(\mathbb{S} 5) .{ }^{9}$ 
However, the transition from the guilds to the citizens' assembly was clearly no solution to the lack of representation. The vast majority of Chur residents without full citizenship were still excluded from voting on municipality issues. There were two options for tackling this imbalance. On the side of the citizenry there was an attempt to make the purchase of citizenship easier. In 1835 an applicant still had to provide evidence of assets of 8,000 fl., $700 \mathrm{fl}$. Einkaufsgebühr for themselves, and another fee for unmarried daughters and underage sons; had to provide evidence of their good character and decent way of life; and had to join a guild to which they had to pay additional fees, and also 'he as well as his family has to acknowledge the Christian-Protestant Church, and have his children to be raised within that said Church.' ${ }^{10}$ The citizenry loosened the conditions for purchasing membership several times, such as in 1845 , when it was emphasised that the citizenry was supposed to be 'strengthened towards the outside and the inside [by way of] accepting good and useful citizens'. ${ }^{11}$ In 1852 the citizenry transferred the authority to accept new citizens from the Bürgerversammlung to the Council to accelerate proceedings, and in 1866, not only was the fee reduced but all denominational restrictions were also explicitly abandoned. ${ }^{12}$ However, success was limited: $73 \%$ of residents in Chur were without full citizenship in 1860 (Giacometti 1999: 100-103, Bundi 2016: 76).

On the other hand, there was an effort to extend municipal participation by way of amendments to the constitution. The lines of conflict ran along the contradicting models of the 'traditional-republican' civic society, with its roots in the pre-modern age and the 'liberal-universalist' civic society as it developed in the wake of the French revolution and the Helvetic Republic (Jäger 2000: 316-317, Bundi 2016: 83, 86-87, 93). In 1860, lawyer Julius Caduff, a resident of Chur, and 75 other signatories handed in a petition to the Bundesrat (national government). They requested that equal rights be granted to the residents concerning the use of the municipality's assets. When this petition had no effect, Caduff reacted through a printed publication, in which he gave detailed reasons for the establishment of a municipality of residents. ${ }^{13} \mathrm{He}$ countered his opponents' argument, according to which the residents were not at all oriented towards the common welfare, by saying: if the virtues of citizens were so much reduced to the interests of each citizen's own community that they would become non-existent already in the neighbouring village, 'then it would truly be a good thing if such a philistine and outdated attitude came to an end as soon as possible!' By constituting civic society not according to a corporation but to the individual, Caduff followed the liberal-universalist model which was typical of the democratic movement as it could be identified in many cantons at that time. In the same way, 18 residents petitioned the Schweizerische Bundesversammlung (Swiss National Parliament) in 1865 to grant them the right to vote on municipal issues by way of federal law. In explanation they lamented the intolerable situation in the Canton Grisons, in their opinion, which, they stated, treated the residents as 'a class of humans without rights' and exploited them financially. Although this petition was also 
unsuccessful, it resulted in serious tensions in Chur and forced the authorities to look for a local solution (Giacometti 1999: 12-16, Bundi 2016: 80-92).

On June 30, 1866, the Council published a draft constitution accompanied by a message which outlined and substantiated in more detail their proposal for moderately extended participation. First, they stated, along with 'increasing traffic', there was strong growth in the number of those residents of the city who were not full citizens; and second, given the poor financial state of the city (high taxes, debts), the desire of the residents to participate was more than understandable. At the same time, however, they emphasised that the "unity of the community' was to be maintained, for it was important to 'maintain at any rate the full-citizen-element as the core of the community'. On the whole, the scope of this revision was much emphasised, by historically placing it among the fundamental decisions in the city's history: 'Since our City's emancipation from the Bishop's dominion and since the introduction of Reformation, the citizenry of Chur have not dealt with an issue of such importance. ${ }^{14}$

On August 26th, 1866, the citizenry, which was solely entitled to decide, rejected the motion with a great majority, and they rejected two similar reform proposals from the authorities in the following two years. The contradicting opinions are illustrated by the fierce reaction to these negative decisions by citizen Peter Jacob Bauer in the Bündner Volks-Zeitung. The citizenry of Chur, he said, consisted of too many 'nitpicky philistines' who had an interest in the city's politics only if it was about 'wood, commons and Alpine pastures'. It was absurd, he said, that in Chur often only 100-120 full citizens were sufficient for an outright majority of votes, and even fewer in elections, to then govern 'more than 7,000 souls'. ${ }^{15}$

The authorities became increasingly puzzled, and on May 2nd, 1868, they called on the citizenry. They stated that 'there are very different opinions about the nature and direction of these proposals' and asked 'associations and private persons to hand in their motions in this concern within 3 weeks'. Five detailed proposals were handed in, the majority of which spoke out against the creation of a Politische Gemeinde but wanted to make naturalisation easier (Giacometti 1999: 16, Bundi 2016: 82). Accordingly, on April 9th, 1870, the Council prepared a bill concerning the easier purchase of citizenship, in the context of which the fee was supposed to be reduced from 1,000 to 600 Francs. The Council commented on the results of the survey and placed it in the wider context of communication: 'The negotiations and voting results at the assemblies of citizens, the proposals and petitions handed in, the voices to be heard from the citizenry and the press contained hints we would not like to go unheard.' Easier naturalisation, they said, was the right decision, as on the one hand it allowed for the joining of new, stimulating elements and on the other hand maintained the principle of full citizen, for the citizenry had 'since times of old been a source of patriotism, devotion and self-confident civism'. ${ }^{16}$

The motion was passed by the citizenry but did not solve the participation deficit; a total of 66 people made use of the opportunity for easier naturalisation, which meant a moderate growth of just 3.5\%. A motion was made by 
the National- und Grossrat Rudolf Planta, which was declared significant by the Grossrat (Great Council) of the Canton Grisons - not least against the current background of the total revision of the Federal Constitution - which, apart from improving the voting status of the residents, also demanded a more just regulation of the commons. On February 1st, 1874, the resulting Law on the Settlement was passed by the people in a Canton-wide vote, with 6,553 in favour and 3,037 against. Therewith, the residents were obliged to 'bear all taxes and burdens like any citizen', taxation only being allowed if the revenue from the property of the full citizens was not sufficient to cover the needs of the municipality $(\$ 14)$. Every Swiss-resident citizen was granted suffrage concerning municipality matters, although suffrage was still limited to full citizens in issues concerning granting citizenship, Armengut (property for the poor), Bürgerlöser (distributed parts of the commons) and the selling of corporation property $(\$ 16) \cdot{ }^{17}$

In the course of working out the bill, a fear of creating a dualism between the Politische Gemeinde (municipality of residents) and Bürgergemeinde (Corporation of Citizens) had been a major point of discussion. On the one hand, the smaller communities were believed to be too weak to establish double authorities. On the other hand there was a fear that by creating a Corporation of Citizens the new municipality of residents would become financially incapable. Notwithstanding all assertions by the special parliamentary commission, however, the division of the community into two distinct election and voting bodies was predetermined by the Canton's new Law on the Settlement. In Chur, the implementation of the municipal dualism became really exemplarily obvious (Giacometti 1999: 16, Schuler 2011, Bundi 2016: 92-106). All Corporations of Citizens in Grisons had been told to adjust their statutes to the Canton's new Law on the Settlement, and the constitution commission of Chur presented a new constitution for the city which was passed by the assembly of residents on March 7th, 1875, with 408 in favour, 285 against and 55 abstentions. In the Kleiner Stadtrat (Small Council - executive) four full citizens and three residents were represented, and in the Grosser Stadtrat (Extended Council - legislative) 14 full citizens and 11 residents.

The Vermögensaufteilung (Distribution of Assets) of the City of Chur was a difficult enterprise. In their message to the citizenry concerning their draft inventory, the Council emphasised that all rejected proposals had lacked a clear foundation for basic law. Only now, through the Canton's Law on Settlement, and the revised Federal Constitution of that same year, was it clear which regulations the city's constitution had to keep. The departing administration had to provide the newly elected bodies with an overview of the financial status 'which must at first be passed by the citizenry before it may be presented to the municipality'. In this context, they stated, everything would have to be done to maintain the Amort der städtischen Schulden (1869), by way of which the citizenry had 'voluntarily accepted burdens to terminate this awful financial mess'. Previously the revenue from the woodlands had provided more than 


\section{Martin Stuber}

two-thirds of the amortised contributions; now the city administration was supposed to receive another 10,000 Francs from forestry. ${ }^{18}$

One month later the draft inventory was discussed at the assembly of citizens. Due to criticism that woodlands and Alpine pastures were listed as property of the municipality, which, it was said, went too far even according to the Canton's Law on Settlement, the majority of the 212 full citizens present voted against the inventory. Three months later a new draft was passed which included the amendment that 'alps and woodlands were to be considered Bürgergut (property of the full citizens) for the inventory'. It also said that although the Corporation of Citizens was no longer involved in the administration, as the owner it was nevertheless 'fully entitled to determine the relevant economic regulations for administering'. Accordingly, in the message to the inhabitants of July 7th, 1875, the Assets of the City of Chur were distributed as follows:

- Assets of the municipality (Inventory No. I): buildings (e.g. City Hall, Municipal School House, churches), real estate (e.g. orchards, field on the Rhine, Rossboden), movables (e.g. stalls, military goods, fire-fighting equipment), stocks (mostly railroad shares), funds (e.g. fund for the building of hospitals)

- Property owned by the Corporation of Citizens (Inventory No. II): woodlands and alps, amendments to forestry plans and alp statutes depending on being passed by the citizenry but revenue being delivered to the General Municipal Treasury, after having deducted expenses for general administration

- Gemeindegüter (full properties of the Corporation) and Armengut (property for the poor) of the "citizenry and particularly its administration and utilisation’ (Inventory No. III). ${ }^{19}$

The Distribution of Assets was constitutive for the Corporation of Citizens as an autonomous entity. On May 4th, 1876, the Citizens' Council passed a Provisional Regulation of the Corporation Administration of the municipality, which served as a basis for employing a Scribe of the Citizens' Council (Giacometti 1999: 42, 175, 190-192, Mohr 1953, Bundi 2016: 109-110, 129-132).

\section{The new role of the Bürgergemeinde in the twentieth century}

Even after the municipal dualism had been created, the assemblies of citizens at first remained as the crucial body of the Corporation of Citizens. Due to the assemblies of citizens being sparsely attended, all matters were decided by way of ballot after 1894, and there was only one assembly per year of the citizens, which had to decide about the accounts being passed by the administration and the yearly accounts (Giacometti 1999: 29-30). Finally even this assembly was abandoned. In general, the Administrative Regulations for the Citizenry (1923) stated: 'Votes and elections are secret, at the ballot' (\$ 4$).{ }^{20}$ The regulations of 
1923 - partly amended in 1995 and 2002 - served as the basis of the inner organisation and were replaced by new statutes as late as in 2014, determining the way in which the Corporation of Citizens is organised today. ${ }^{21}$

Immediate contact between the citizenry and the authorities it elected was lost due to the disappearance of the assembly of citizens. This gap was filled by the Bürgerverein (Association of Citizens). Its President, Martin Studer, emphasises its function as a mediator due to the new statutes of 2014, which once more shifted decision-making from the citizenry to the authorities. ${ }^{22}$ At the same time, the Association of Citizens had an interest in maintaining sociality. The one-day trips, for which there is evidence since 1914, went mostly to one of the Chur alps or to a Maiensäss (seasonally cultivated alp). According to its own wording of 1950, the Association of Citizens considered these trips served the purpose of 'supporting once again the adherence to the ancient traditions, supporting the love of the home region, and maintaining coherence among the citizens' (Bundi 2016: 286-294). Martin Studer also considers the significance of the Bürgerverein over which he presides to be the maintaining of tradition, which he contrasts with increasing virtual communication: 'We attempt to make the people somewhat more familiar again with traditional values. I find that, given all digitalisation and the internet, many need opportunities to meet "face to face""23 The Association of Citizens still organises "a trip to one of the Chur alps every two years, and the participants are offered something to eat, soup, roast meat, and the like. Then up to 400 people go walking up there. ${ }^{24}$ The Bürgerverein offers these trips as well as a number of other occasions, such as a New Year's meeting at the City Hall, and fondue with Chur alpine cheese in a tent on Kornhausplatz for 500 people $^{25}$ (see Figure 6.3).

The number of citizens remained more or less constant from the constitution of the Bürgergemeinde (1875), until the end of the twentieth century, while the number of residents more than quadrupled. As a result, the percentage of the citizens fell from just under a quarter to one-twentieth. Since 2000, however, the trend has been reversed (see Table 6.1).

In the 1980s and 1990s, a number of applications for citizenship by people with a migration background were rejected by the citizens at the ballot box,

Table 6.1 Development inhabitants/citizens

\begin{tabular}{llll}
\hline & Residents & There of citizens & Citizens in \% residents \\
\hline 1876 & 8,177 & 1,889 & 23 \\
1900 & 11,718 & 1,564 & 13 \\
1925 & 15,240 & 1,650 & 11 \\
1950 & 19,277 & 1,677 & 9 \\
1975 & 33,236 & 1,509 & 5 \\
2000 & 33,728 & 2,351 & 7 \\
2019 & 37,687 & 5,755 & 15 \\
\hline
\end{tabular}

Sources: Giacometti 1999: 28; VB BG 2000:9; VB BG 2019: 23. 




Figure 6.3 Fondue organized by the Association of Citizens, on the Kornhausplatz in Chur 2017 https://der-buergerverein.ch/veranstaltungen/.

which led to external and internal criticism. In the 1982 administrative report of the Bürgergemeinde it is regretfully stated:

the fact that in the two votes six young and hopeful foreigners born in Chur spent their childhood in Chur, went to school in Chur, enjoyed their education in Chur in whole or in part, spoke Chur German and did not speak the language of their original home country, with which they no longer have any relationship, were rejected, is a sad fact and makes one think. ${ }^{26}$

Due to the decision of the Federal Supreme Court, ${ }^{27}$ according to which naturalisations at the ballot box are unconstitutional (2003), the Corporation of Citizens transferred the naturalisation competence to the Citizens' Council in 2004. ${ }^{28}$

Even before that, the Bürgergemeinde had already launched a naturalisation campaign in 2001, where it sent out over 8,500 personal invitations to Swiss people who had been resident in Chur for at least 25 years; within six months the number of citizens had almost doubled. In the administrative report of the Bürgergemeinde, this success is commented on as a necessity:

The marked increase in the percentage of citizenship in the total population was also urgently needed, as the Corporations of Citizens were repeatedly reproached for having a high level of competence, but being only a small minority that could make exclusive decisions on important general business. ${ }^{29}$ 
A second intensive advertising campaign, Khur-mini Stadt, was run in 2009 with great support from the media (articles, interviews, film reports), ${ }^{30}$ and a third in 2019. Flyers informed 13,000 households in Chur about the possibility of being able to apply for membership in the Corporation of Citizens in an administratively simplified form for only $300 \mathrm{CHF}$ per application. The campaign lasted six months and was aimed at all Swiss people who fulfilled the legal requirements at that time. ${ }^{31}$ The result of this is the current citizenship share of $15 \%$.

In the Canton Grisons the position of the Corporations of Citizens and its relationship to the municipalities has been legally clarified since the Gemeindegesetz of $1974^{32}$ and was consolidated with the current Gemeindegesetz of 2017,33 after previous attempts via cantonal votes in 1945 and 1966 failed (Schuler 2011, Bundi 2016: 183-293). The financial flows between the Corporation of Citizens and the municipality were closely examined in the Leistungsüberpüfung (2013, performance audit), and adapted to the cantonal legislation. ${ }^{34}$ Despite this secure legal foundation, today's exponents of the Corporation of Citizens are concerned about their public legitimacy. Martin Studer notes: 'With the current political discussions and currents in which the existence of the Bürgergemeinde is being questioned, I believe that we must communicate what we are doing much more actively so that we have a right to exist. ${ }^{35}$ Marco Caduff puts it similarly when he wants to emphasise more strongly the role of the Corporation of Citizens as a provider of funds for social and cultural purposes: 'If you give the money, you want people to know that you give it. ${ }^{36}$ For Reto Mani, it is above all important to make visible those services that are complementary to the local community, so that in 10 or 20 years someone could say: 'If it weren't for the Corporation of Citizens, we wouldn't have it now.' 37 The Bürgergemeinde implemented these goals together with an advertising agency in the form of a new website, among other things, which focused on the commitment of the Corporation of Citizens to the quality of life in Chur. ${ }^{38}$

\subsection{Transformation of the forest economy}

Since the beginning of the independent development of the city in the Late Middle Ages the Chur forests have been owned by the citizenry respectively the Corporation of Citizens. In the long run, the superior principle of sustainability is realised by way of different and sometimes contradictory goals, which indicates how fundamentally the energetic foundations of 'agrarian society' (solar energy), 'industrial society' (coal imports) and 'consumption society' (global availability of mineral oil) have changed (see Chapter 2). ${ }^{39}$

\section{Exclusive supply with natural products in the 'agrarian society'}

The first comprehensive forest statute of Chur was passed by the Council in 1766. It banned everything from the lower forest areas, which were closer to the city and were thus overused, except for collecting Windfall (scrawny 
branches on the ground). In the upper parts cutting firewood was still permitted for private purposes. Collecting dry leaves and moss was allowed if 'done modestly', but not the use of needles and grass. These forest statutes were passed by the Council but rejected by the guilds. Their resistance must be interpreted in the context of the ancient idea of woodlands as shared property. Whereas the Council considered itself the superior owner, having the authority to supervise, the guild members based their exploitation of the forest on a historically grown network of individual written concessions and customary rights (Spinatsch 2005: 17-21). What made this conflict socially explosive was the previous reduction of the guilds' regime to only a few families (see Section 6.2).

Legal texts from the Early Modern Period are fruitful sources, not only because they could affect practices but also as declarations of postulated intentions. Accordingly, bans on traditional ways of exploiting woodlands, such as wood pastures or collecting plant litter, are often less indications of successfully suppressing them but rather, on the contrary, evidence of their existence (Ernst 2000; Stuber and Bürgi 2012). From this point of view, the printed Forst- und Waldordnung Löbl. Stadt Chur (1791), which also was not met with agreement by the guilds because of their resistance to any professional forest inspector, will be assessed in more detail. ${ }^{40}$ The superior maxim was formulated right at the beginning of the forest statutes, that is 'not to expose our innocent descendants to deprivation'. This implicit sustainability principle found expression in the intention to 'provide the citizenry with ever more and cheaper timber and firewood', in the context of which the Bürgerholz (the guaranteed yearly amount of wood for the citizens) could not be sold to third parties ( $\mathbb{I X}$ ). A continuous supply was supposed to be realised on the basis of a 'geometric measuring of the width and height of all their woodlands' $(\mathbb{S} \mathrm{I})$. This was intended to provide for a sustainable structuring of woodcutting, as also presented in the Outline of the Unterthor Woodlands of the Worthy City of Chur. ${ }^{41}$ The 13 forest districts were structured into a total of 339 Jahresstriche (yearly cuttings), and these again into two or three Holzschläge (woodcuttings) each. Given a turnover of 100-120 years, sustainable exploitation allowed for three cuttings every year. To guarantee protection against landslides and avalanches, however, this possible yearly area had to be distributed over a total of none yearly cuttings, in the context of which only one cutting took place ( $S$ II). The reforestation of lumbered areas was not supposed to be 'left to the arbitrary workings of nature' but to be purposefully supported by clearing and seeding. The city's foresters were supposed to acquire the necessary knowledge 'by way of purchasing the most indispensable new books published in this science', and foresters were needed who did not 'understand forestry in the traditional ways but as a science' $(\mathbb{S}$ XI, XXXI). Every September a deputation from the Council had to assess the intended cuttings on site and to estimate how much wood was to be expected. After deducting what was to be given to the municipal administration and the almshouse, the amount left could be distributed among the citizenry ( $\mathbb{V}$ VII).

By attempting to connect the Bürgerholz to the long-term harvest of the city's woodlands, the primacy of sustainability was postulated for the first time. 
Chur's forest economy thus proves to have been part of the reform movement towards a science-based, sustainable production of wood which was spreading across Europe at that time (see Stuber 2020). At the same time, however, the Chur Forst- und Waldordnung of 1791 may be read as evidence of the comprehensible supply function - typical for 'agrarian society' - which went far beyond securing the citizens' needs for timber and firewood. This becomes obvious from the differentiated information about types of wood. Socmen were also allowed to take the branches, Spitzlinge (treetops) and sticks remaining after the production of wood $(\mathbb{S}$ IV). The alluvial forests on the banks of the Rhine provided firewood for heating the City Hall and water-resistant alders for protecting the banks, as well as for wooden water supply mains (\$ 3 ). Young birches were used for brooms, bushes for fascines, and fir as well as larch branches were woven into fences ( $\mathbb{X}$ XIV-XVII). Additionally, many forms of agrarian use can be described. Wide areas of the city's woodlands served as pastures; and now the forest statutes ensured that areas with trees younger than 20 years would not be used as pastures $(\mathbb{X}$ XIII). The production and utilisation of resin, pitch and tar was also regulated ( $\mathbb{X}$ XIX-XXII). The collecting of plant litter was regulated in most detail. Basically, this was only allowed in areas with trees older than 40 years, and only for current private use but not for stockpiling or sale. Exclusively reserved for the citizenry were the forest districts in the closer vicinity 'which are most convenient for them. Only the further forest districts were open to the socmen for collecting plant litter (\$XVIII).

How indispensable these agrarian ways of exploiting woodlands were during the 'agrarian society' is clear from the fact that violations of these regulations were at that time hardly sanctioned. A comprehensive analysis of the Chur court files shows that plant litter offences were systematically recorded at the Stadtvogteigericht only from 1800 on, and pasture offences only from 1830 on (Spinatsch 2005: 33).

\section{Municipal financial resource in the 'industrial society'}

In the course of the nineteenth century the city woodlands as an exclusive supply for the citizenry was transformed into a municipal financial resource. Whereas only in the last third of the century was access granted beyond the exclusively entitled citizenry, the gradual reorientation of the sustainability goal from supply to monetary return had already started in the first half of the century. One trigger was the Forstordnung des Kantons (1839) which obliged the communities to devise regulations for their woodlands $(\mathbb{S} 20) .{ }^{42}$ In 1842 , the Council of Chur suggested such a forest law to the citizenry. It explained the need for this as the yearly deficit of forestry was, it said, due to the large amount of cheap Bürgerholz. Part of the yearly harvest of wood should be sold freely, it was stated, in order to balance the accounts (Waldungen 1953: 163). Only a modified Proposal was met with agreement. The introduction spoke of a 'regulated cultivation and exploitation of our forest property', giving expression to the shift from natural revenue to monetary revenue. At the same 
time, however, supply priorities were still fixed. The need for firewood and timber of the administration and public institutions were to be supplied first from the forest revenue $(\mathbb{S} 2)$. In the next step, the Council had to fix the size of the Bürgerholz, based on an assessment by the forest commission ( $\mathbb{S} 3$ ). The surplus was only to be publicly auctioned among the citizenry in the last step (\$ 7). Citizens who were residents of Chur, as well as the widows of citizens, were entitled to a complete Holzloos (lot of wood) - for 15 Francs. Unmarried women with citizen status and living in their own households were entitled to half a Holzloos (\$4). Tax-paying residents living in their own households were also entitled to half a Holzloos, however only 'as long as nothing else is required from the side of the worthy citizenry' $(\mathbb{S} 5)$. Being supplied with plant litter for 15 kreutzers a cart load - was reserved only for those entitled to a complete Holzloos, the total amount being fixed by the forest commission (\$ 8). ${ }^{43}$ Also subject to the verdict of the forest commission was grazing on wood pastures, which was now allowed only in those forest districts where it was considered 'not disadvantageous to the forest culture'. Possible claims to grazing rights by other communities or private people were supposed to be 'claimed, investigated and stated in an appropriate way, and those which seem to be legal [are] supposed to be released, if possible' (\$ 11$)$, according to the above-mentioned forest statutes of the Canton (1839). ${ }^{44}$

The Forest Policing Ordinance (1846) was passed one year later to sanction any violations of the 'forest-appropriate treatment' of the city woodlands, which were published in Chur's official gazette. It was also distributed among the communities in the vicinity, 'so that any evildoers can no longer pretend not to have known'. Without the permission of the forest inspectors and forest wardens, who had been sworn in by the city, nobody, 'neither citizen nor resident', was allowed to make use of anything coming from the forest $(\mathbb{S} 2)$. Anybody who was encountered in the forest away from the common paths wearing 'a cutting or sawing weapon bigger than a common pocket knife' was considered an evildoer $(\mathbb{S} 4)$. A number of traditional ways of exploiting the forest were explicitly mentioned as punishable violations if used without written permission, such as collecting forest fruits, moss and stones $(\mathbb{S} 5)$, taking away minor assortments of wood (slips, sticks, windfalls), as well as making plant litter, resin and juice $(\mathbb{S} 6)$. A double fee was to be paid for deeds committed on Sunday and holidays, or during conflagrations, and the fees for deeds committed between dusk and sunrise were raised by another pound $(\mathbb{S} 10)$. In cases of recurrence the fee doubled, and the socmen were expelled from the city after the fourth recurrence $(\$ 11)$. Parents were held accountable for violations committed by children younger than $16(\mathbb{S} 12)$. Every month the forest wardens had to hand in their diaries to the forest inspector, "where they exactly record the violations, giving all the details' ( $\left(\right.$ 14)..$^{45}$

The Chur forest economy was praised for its successful combination of professionalisation and repression by the Canton's forest administration, as a pioneer achieving the highest net revenue. In its Report on the Administration of the District it stated: 
However, for the time being, all over the Canton it has been possible to speak of appropriate forestry only in the City of Chur which is thus ahead of all other communities, giving a praise-worthy example and thus achieving the greatest return from its woodlands.

The same report lamented that the neighbouring communities of Haldenstein and Maladers were lagging far behind concerning forestry. There, it said, was a 'terrible mess', as many inhabitants of these municipalities were 'striving for unlawful gain' and were not prevented from trading in wood with the nearby City of Chur. ${ }^{46}$ The reporting author was Johann Coaz, who had been the Canton's Oberforstinspektor and later Superior Forest Inspector of all Switzerland. Coaz and Elias Landolt were the leading duo shaping Switzerland's forest policy until the end of the nineteenth century and firmly rooted sustainable forestry at the national level. ${ }^{47}$ It was Coaz who, in 1854, together with Chur City forester Sixtus Camenisch, worked out the first Wirtschaftsplan (business plan) for the city woodlands. The core of this plan was the determination of the yearly, sustainable amount of wood to be cut. This depended on the exact mapping of the age of a tree population at a given date. ${ }^{48}$ The first finding was that especially in the lower districts of the City forests 'too many trees had been cut down, so that they had to be careful'; the plan provided for the exploitation of the upper areas and pointed out the necessary improvement of transport routes. In retrospect, this business plan was the starting point for the comprehensive exploitation of Chur's city forests (Waldungen 1953: 164). ${ }^{49}$ In the 'agrarian society' the principle of spatial closeness and distance resulted in a patchwork of different degrees of exploitation - which from today's ecologic point of view must be considered an advantage - whereas a network of transport routes and systematic planning is used in 'industrial society' for a homogeneous degree of exploitation.(see Figure 6.4)

The Distribution of Assets (1875) which left the property rights to the city woodlands with the Corporation of Citizens but attributed the exploitation rights to the municipality was crucial for the transformation from woodlands exclusively for the benefit of citizens to a municipal financial resource (see Section 6.2). Under these new auspices, the Forstordnung der Stadtgemeinde Chur $(1886)^{50}$ continued the development towards a market-oriented forest which was supposed to generate monetary return, whose revenue, however, no longer exclusively benefitted full citizens, but all residents. Within the 'limits of the revised forest statutes' $(1877)^{51}$ there was an attempt to 'increase the value and yield capacity of the entire City woodlands'. The business plans with the fixed yearly amount of wood to be cut were usually presented to the Citizens' Council for assessment according to whether 'the sustainability of the woodlands was not affected' (\$ 1$)$. Within the fixed scope, however, the actual amount per year had to be oriented at the respective market situation: 'in case of high prices for wood more shall be sold, and less in the case of low prices' ( $(8)$. As always, the yearly harvest of wood was used for, first, covering the needs of the municipal administration and poor welfare, second, for handing 


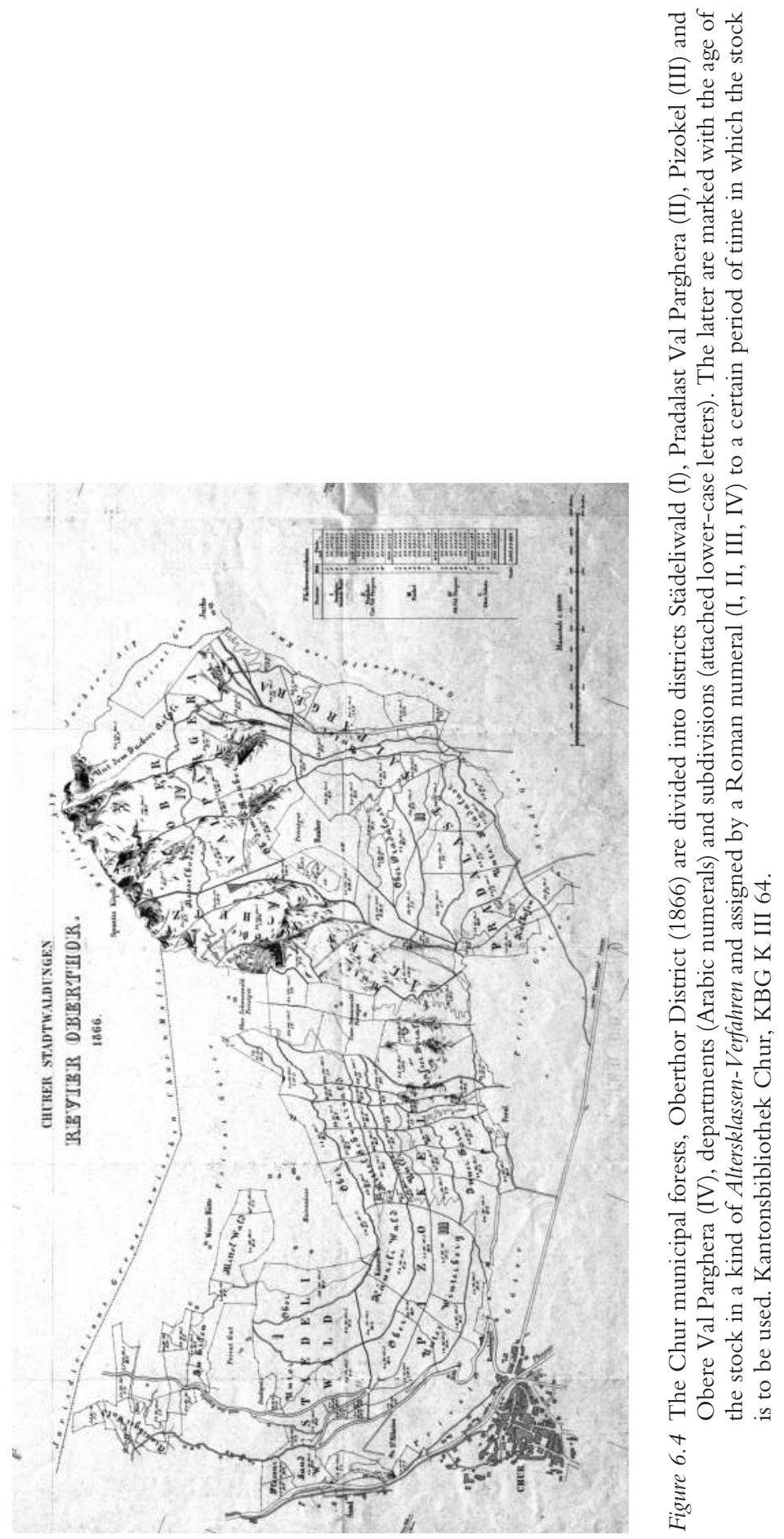


out the Bürgerholz - 30\% below the market price - and third for selling the surplus. It was new that now the latter took place not only among the citizenry but on the free market $(\mathbb{S} 9,12)$. The agrarian exploitation of the woodlands was only mentioned in passing. Grazing was banned, with the exception of the Mittenberg pastures, as was the production of resin, and the harvesting of grass; only the controlled collection of dry leaves in sacks and moss, as well as small Christmas trees, was still legal for a fee $(\ 19,20)$.

It seems that the City woodlands had largely lost their supply function at that time, which is in line with the general transformation from an 'agrarian society' to an 'industrial society'. The developing railway network, which allowed access to coal from France and Germany, was crucial for the transition from one energy system to the other. Chur was connected to the St. Gallen-Sargans line in 1858, which resulted not only in relief for the City woodlands but also new sales opportunities. In the Auszug aus dem Wirtschaftsplan (1907) there is the remark:

Timber is sold easily for good prices to the local shops, and also abroad. Every year large amounts go to the sawmills on Walensee and often even to the Cantons of Zurich, Aargau, and Schaffhausen, for which the nearby train station is very helpful, of course. ${ }^{52}$ (see Figure 6.5)

Until the mid-1960s the goal of the continual financial gain pursued by Chur's forest administration produced more or less regular surplus revenue. In this way the dynamically developing municipality - the number of inhabitants more than doubled, from 8,177 in 1876 to 19,277 in 1950 - was provided with essential funding (Töndury 1949, Giacometti 1999: 80, Bundi 2016:



Figure 6.5 Wood processing on Post Square, Chur 1909. Stadtarchiv Chur, F 10.014.088. 
106-111, Brändli 2019). That the forest administration was still operating in the black by the end of the 1950s despite rising wages was believed to be due to, first, mechanisation, ${ }^{53}$ and second to the skilfully arranged wood assortment which was oriented at a dynamic market. Accordingly, given the decline of timber prices in 1958, the municipal forest administration noted: 'It would be pointless to work towards a price slump by way of oversupply. We have thus extended our exploitation to the younger population where almost no timber but much pulpwood can be produced. ${ }^{54}$

\section{Protection, recreation and nature in the 'consumption society'}

With the beginning of the 'consumption society', as a result of declining prices for fossil energy resources, the revenues from the timber industry went down. Despite mechanisation and rationalisation, since the mid-1960s Chur's forest administration had started operating in the red. The stagnating or even declining wood prices could not keep pace with the rising production costs. Accordingly, the municipal forest administration reported for the year 1966 that cost accounting was on the one hand burdened by rising wages while on the other hand sales were declining: timber, it said, was replaced by alternative building materials, firewood was under pricing pressure, and pulpwood was suffering from foreign competition. ${ }^{55}$ For the year 1975 it stated: 'The forestry situation is characterised by production costs having risen enormously over time, whereas sales revenues have been stagnating or even declining. ${ }^{56}$ And for the year 1988 it was emphasised that currently there was no stopping the worsening economic situation of the forestries, 'not even given the paid subsidies. ${ }^{57}$ As another reason why the forest administrations were operating in the red, District Forester Toni Jäger names the additional tasks given to them, namely building supervision structures for debris and all ravines, drainages and road constructions, all of which had in the past been the business of the civil engineering department and the works yard. Although such construction works were subsidised by the Confederation and the Canton, still the remaining costs and maintenance expenses were a burden for the coffer of the forestry. ${ }^{58}$

The most important revenues are today the subsidies for the maintenance of the protective forests $-80 \%$ of Chur's woodlands counted among this category. Jäger compares the present to the recent past:

In the past we spoke of revenues from wood, then we made almost one million in wood, and today it's just half of it, and the other half is covered by contributions from the Confederation and the Canton - thanks to our extended maintenance of protective forests.

Jäger also mentions the thus resulting, radical consequences for the understanding of sustainability. Whereas in the past 'sustainable' meant first of all 'no overuse', today it is almost the other way round. For the sustainability of a protective forest, a minimum amount of cutting is indispensable as otherwise it will become overmatured..$^{59}$ 
Furthermore, gradually the recreation function and natural values of the woodlands moved to the fore. The Waldgesetz der Stadt Chur (1999), depicts this extension of the functions of woodlands:

Within the limits of superior law, the Chur woodlands must be cultivated sustainably and close to nature. Its many functions, in particular those of protection, utilisation and welfare, must be considered for forest planning and be guaranteed by way of forest tending' (\$ 6). ${ }^{60}$

Accordingly, the Betriebsplan (2004) emphasised a number of nature conservancy measures. In Chur's woodlands, it said, no chemical aids were used. Furthermore, one proceeds mostly by way of regeneration, in the context of which deciduous trees and rare conifers such as the yew were particularly supported. Individual, old or particularly beautiful trees are left untouched to revaluate the habitats of insect and bird species, just like deadwood and pioneer tree species. Open pastures, it says, are mowed at regular intervals, drains are left open if possible. ${ }^{61}$ It may also be considered a consequence of such measures that two years later the municipal forest administration was glad to announce that it had successfully passed the audit for the International Certificate of Sustainable Forestry (FSC Label). ${ }^{62}$

Urs Crotta, head of the Grün- und Werkbetrieb of the City of Chur, uses drastic wording: 'Without intact woodlands, the city would partly be uninhabitable. ${ }^{93}$ Member of the Citizens' Council Martin Studer emphasises that same fact and assumes that the people are indeed aware of this. ${ }^{64}$ On the other hand, he says regretfully, the urban milieu often ignores the fact that the forests also serve production purposes. ${ }^{65}$ Already in the Betriebsanalyse of the year 2003 there is the statement that people are much aware of the prioritised protective function but little aware of the production function. This finding leads to the recommendation to emphasise the ecologic advantages of woodcutting by way of 'political and environmental education communication' (Forst- und Alpverwaltung 2003: 17).

Urs Crotta emphasises, it is not at all a matter of course that such attempts at raising awareness are successful. For example, a Forest Day organised by the municipal administration had been attended by hardly 30 people - 'those people who are anyway interested in the forest'. On the other hand, the Association of Citizens had tried to 'organise a Citizens' Day in the forest, and on that occasion there appeared quite a number of people - 200 to 300, however, that was connected to eating out. ${ }^{66}$ Also Martin Studer remembers this occasion, for which the Association of Citizens he presided over had been responsible:

Five years ago, for example, we organised a Day when Toni Jäger with his team demonstrated how forest management works, so as to give the people an idea. On the one hand, the citizens are certainly interested in how the forest in its function as a local recreation area is tended and cultivated. On the other hand, the members of the Association appreciate any occasion on which they may experience a cosy get-together with food and drink. ${ }^{67}$ 
Behind this different response there might be more than food and drink. Probably the citizenry's centuries-old forest property resulted in a closer emotional relation to the forest resource than sheer residence would. The longevity of the Bürgerholz points into a similar direction. Still today the citizens are granted firewood from woodlands with a $20 \%$ allowance. The difference to the normal price is paid back to the municipality by the Corporation of Citizens. Maintaining this symbolic gesture for the members may definitely be considered a strategy, says Urs Crotta: 'The Corporation of Citizens pursues an offensive practice of granting citizenship, and it is interesting that, among others, the people respond to this because there is cheap wood to get. ${ }^{68}$

\subsection{Transformation of the land use}

In the time of the 'agrarian society', the majority of the population of Chur was involved in agricultural self-sufficiency. Livestock farming was clearly at the centre of this. Even in about 1800 there were still more than 800 head of horned cattle from about 200 owners to count in Chur, and the city's own livestock farming largely covered its meat and dairy product needs (Jecklin 1993b: 146-148). ${ }^{69}$ But the range of food security went beyond the boundaries of the city. On the one hand, Chur depended on grain imports from the Swabian and Milan regions, while on the other hand, Chur extended its resources by way of purchasing Alpine pastures at Arosa.

\section{The Chur Allmende}

In the Statutes of the City of Chur of 1368/1376 under the name 'der burger waid', the Allmende (common lands) can be basically identified for the first time. Council and citizens, as well as the Bishop, agreed, that 'everybody in his own way shall make hay, and may do so, after having been treating it with dung, and water, and may take it in and has fenced it off.'

In the Early Modern Period the Churs' Allmende was regulated by the two sub-communities of Oberthor and Unterthor. They were spatially separated by the Mühlebach which ran right through the city. The members of the two sub-communities gathered at the town hall on the first Sunday in March and elected the administrative authorities. Voting rights and full access to the Allmende was exclusively reserved for guild citizens; the Hintersassen (socmen) on the other hand were only limitedly entitled to utilisation. By the Zunftverfassung (Constitution of the Guilds) it was determined which guild had to provide herdsmen for which kinds of animals. The Rebleutezunft was in charge of cattle, the Schuhmacherzunft was in charge of oxen, sheep and calves, the Schneiderzunft was in charge of pigs, the Pfisterzunft was in charge of goats and the Schmiedezunft was in charge of horses. If Guild Masters were not able to employ the shepherds in time, fines were imposed both on the town treasury and the guild treasury (Jecklin 1993b: 144, Bundi 1993a: 266, Bühler 1993b: 232-233, Bruggmann 2017: 224, Wendler 2018: 44;). 
The different usable areas of agricultural land in the Chur territory largely followed a topographical order:

- On the higher-lying areas, which were less exposed to the floods of Plessur and Rhine, the intensively cultivated land with fields, vineyards and meadows, which - at least in the reconstruction for the period 17751820 (Fuchs 2011: C1) - largely consisted of private properties; the haymaking on the meadows was central to the agriculture of Chur, which was oriented towards livestock farming, but also for the transit trade.

- On the plain between the city and the river Rhine below the elevation curve of 570 metres above sea level, there were originally uncultivated wetlands with alder woods, reeds and sandbanks, which were covered by river debris and boulders, changed their appearance after each flood and were used as extensive pasture. The cultivation of such land was largely a joint effort by the citizens. The newly acquired land was divided into plots of land and handed over to the individual citizens for use for a modest interest. Especially in the eighteenth century, such common land was repeatedly segregated, parcelled out and given to citizens for individual use as private property - or on a temporary basis as Bürgerlöser, which often served the self-sufficiency of poorer families of the citizenry (Schorta 1942, Jecklin 1993b: 147, Bundi 1993c: 462-464, Plüss 2020: 11-20)..$^{70}$

An additional dynamic can be observed. Gemeinatzung or Trattrecht was the temporary grazing right of the community on all private plots of land located on its territory and not expressly exempted from it. The Council had to intervene time and again and demand that private individuals undo the fencing they had erected. Sometimes, however, it complied with requests for fencing, especially if the citizens concerned were influential and wealthy. The two tendencies observed since 1600 - first to distribute pasture land to private individuals, second to withdraw it from the Gemeinatzung - led to a sharp diminution and reduction of the Allmende. This development is only understandable in view of the fact that Chur was concerned about pasture replacement elsewhere, namely in Arosa (Bundi 1993a: 268-270, Bundi 1993c: 457, Jecklin 1993b: 144-146).

However, the collective pasture in Chur itself remained indispensable as part of the transhumance system until well into the nineteenth century. The Weidgangs- und Allmeindenordnung (1830) precisely recorded the collective grazing rights, which were finely differentiated in space and time (see Figure 6.6) The spring and autumn grazing before and after the Alpine summer in Arosa was the main focus; the corresponding areas were on the right side of the Plessur for the sub-community Unterthor and on the left side of the Plessur for the sub-community Oberthor. Particularly noteworthy are some higher-lying areas that were used as an intermediate stage during the course of the year (including Maiensäss, Pramontan, Rüti, Mittenberg). To supply the town during the Alpine summer, the summer pasture was used for milking cows; every citizen could buy a home cow at the May market and drive it to the pastures, 


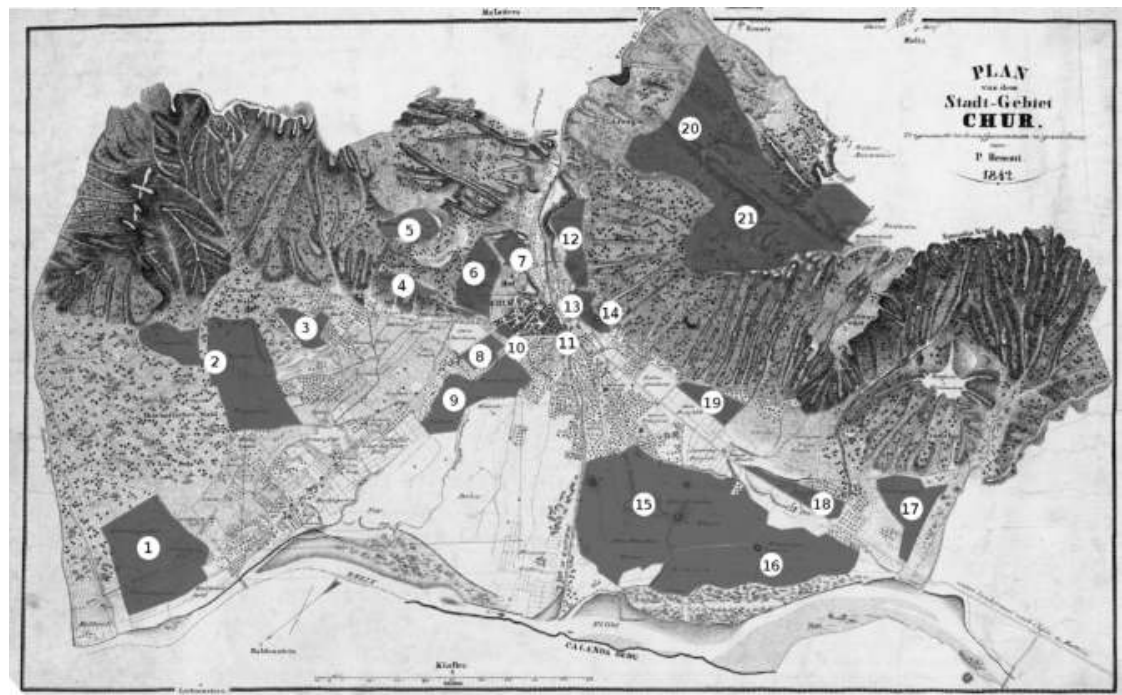

Figure 6.6 Common grazing in Chur, at about 1830. Sources: Weidgangs- und AllmeindenOrdnung löblr. Stadt Chur, wie solche durch die Mehren löblr. Zünfte vom 25 April 1828 zum Gesetz erhoben worden ist, Chur 1830; Plan von dem StadtGebiet Chur (1842). Trigonometrisch aufgenommen und gezeichnet von P. Hemmi. Stadtarchiv Chur, E 0-222.

1 «Unterthorer Allmend»

- spring and summer pasture (horses)

- 25.05 until the "Alpfahrt" (cows Unterthor)

2 «Praserin, Campodels, Böschen»

- until 25.05. (cows Unterthor)

- 17.09.-10.10. (cows Unterthor)

- 4.10.-11.10 (horses)

3 «Lürlibad»

- 11.10.-13.10. (oxen)

4 «Vogelboden»

- summer pasture (dairy cows)

5 «Mittenberg»

- spring pasture (oxen)

- summer pasture (dairy cows)

6 «Halde»

- spring pasture (oxen)

- summer pasture (dairy cows)

7 «St. Luzi»

- sheeps

8 «Untere Quader»

- 29.10. (cows \& horses)

9 «Lachen- und Sagenwiesen»

- 21.-29.10. (cows Unterthor)

- 12.10.-29.10. (horses)
10 «Unter der Stadt» (Lokalisierung unsicher)

- 21.-29.10. (cows Unterthor)

- 11 «Unter der Stadt» (Lokalisierung unsicher)

11.-20.10. (cows)

12 «St. Hilaria und St. Antönien» meeting place "Alpfahrt» / "Alpentladung»

13 «Kälberweide, Galgenhügel» sheeps

14 «Stierenwiese»

- 29.9. until 10 Uhr (cows Oberthor)

15 «Gross- und Kleinbrucker-Wiesen»

- 17.-29.10. (cows Oberthor)

16 \& 17 "Oberthorer Allmend»

- Spring pasture (cows Oberthor)

- 3.10.-08.10. (cows Oberthor)

18 «Plankiswiesen»

- 29.09.-02.10. (cows Oberthor)

19 «Trist»

- 14.10.-29.10. (oxen)

20 «Pramontan, Rüti»

- until 25.5. (cows Oberthor)

- 26.09.-11.10. (cows Oberthor)

21 «Mayensässe»

- 27.9-10.10. (oxen) 
even if he had no other cattle or meadows on Chur territory. The importance of the transit traffic is indicated by the separately listed grazing rights for the oxen and horses used as draught animals. ${ }^{71}$

The cantonal constitution of Graubünden (1814) already provided the sale of common grazing rights. In the following years, the Grand Council of the Canton unsuccessfully recommended that the communities put this into practice. Two proposals for laws to replace the grazing rights in 1836 and 1841 were rejected in the cantonal referendum. In 1850, the cantonal law Die Loskäuflichkeit der Weidrechte auf Privatgütern ist zugesichert was passed. In 1861, the City of Chur decided on the compulsory replacement of grazing rights, after several proposals of the Council had not been implemented (Moosberger 1891: 133-140, Curschellas 1926: 29-34, Passini 2004: 26-28).

In the Distribution of Assets (1875) between the Bürgergemeinde and the Politische Gemeinde, the Gemeindegüter was assigned to the full ownership of the Corporation of the Citizens (see Section 6.2). In addition to various buildings, the Gemeindegüter included above all the aforementioned Bürgerlöser (distributed parts of the Allmende). While these still fully performed their supply function for citizen households even in the outgoing 'agrarian society', this changed fundamentally in the last third of the nineteenth century with the onset of the 'industrial society'. Increasingly, the Bürgerlöser were no longer farmed by the citizens themselves, but were leased to the remaining agriculturally active population at profitable field rates. In line with the transition from a subsistence to a commercial economy, the structure of small plots of land was dissolved in favour of large contiguous areas that were more suitable for mechanised farming. With the transition to the 'consumption society' since the mid-twentieth century, the Gemeindegüter has taken a new turn. Strong population growth led to the gradual expansion of Churs' built-up urban area into the Rhine plain, which resulted in land cessions by the Corporation of Citizens and the relocation of the agrarian used Gemeindegüter to the periphery of the territory (Plüss 2020) (see Figure 6.7).

At the same time, however, a continuity can be observed, since a large part of the present agricultural area is owned by the Corporation of Citizens, the former Bürgerlöser. Also among the Gemeindegüter in the town area are numerous buildings and Bodenrechte (leasehold estates), as well as the Maiensässe, which are recognisable as large forest clearings (see Figure 6.7). These different categories of Gemeindegüter listed here represent, first, central sources of income for the Corporation of Citizens. Second, in their present situation they are to a large extent the result of purchase and exchange processes in the twentieth century. And third, they are linked to Arosa via the Bodenerlöskonto (land revenue account), in that the land sold there financed the purchase of land in the City of Chur (Buchmann 1977, Gerber 2008, Moll 2020).

\section{The Chur alps at Arosa}

Today, the Chur alps at Arosa are considered a showpiece Grisons's alpine agriculture and a perfect example of the successful symbiosis of alpine agricultural 


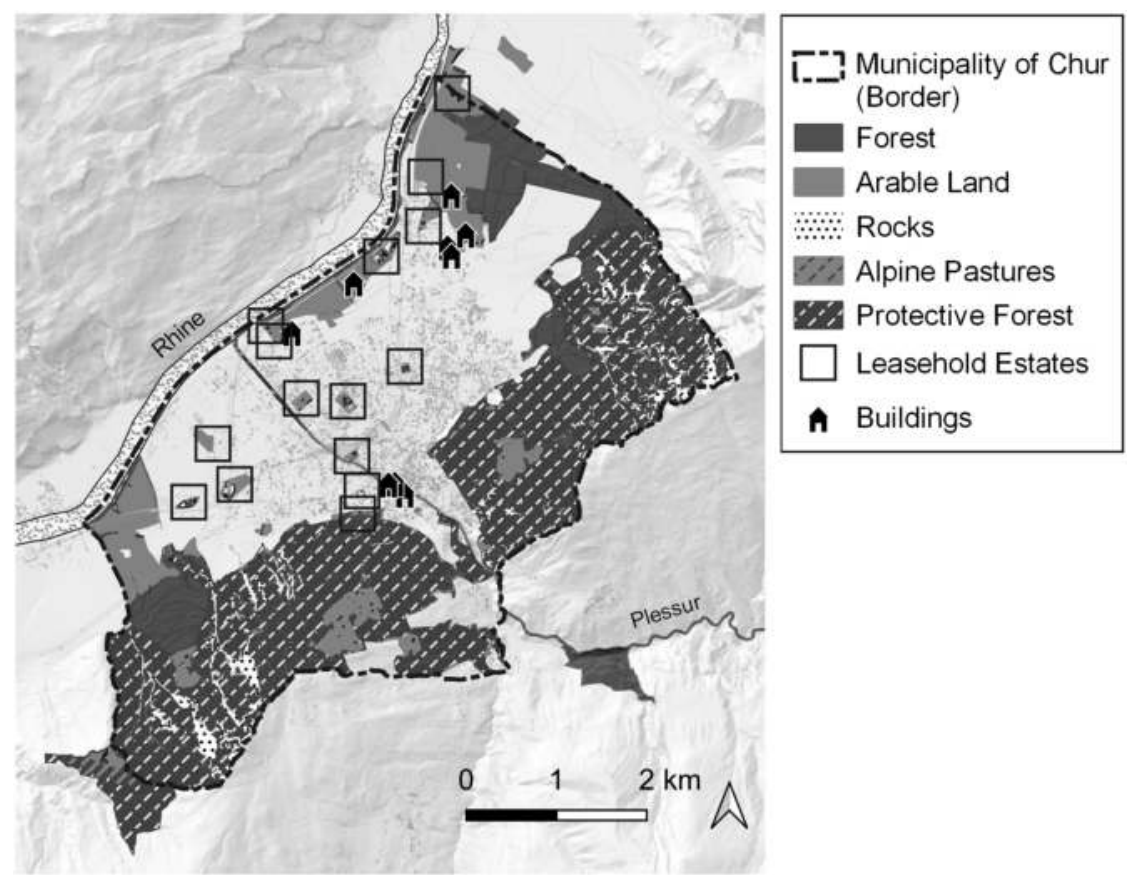

Figure 6.7 Landed property of the Bürgergemeinde Chur in the territory of the city, about 2020. Map compilation and design by Sarah Baumgartner, University of Bern; geodata source: Amtliche Vermessung (AV), Kanton Graubünden, 2020; hillshade: DTM-AV, Kanton Graubünden.

and tourist development. ${ }^{72}$ Behind this there is a restructuring of space which was to a large extent moderated by Chur.

Chur as an agricultural city was based on the system of transhumance, completing the scarce commons in the city territory. In 1544, Chur appeared for the first time as an owner at Arosa; in the further course of the Early Modern Period the city purchased most of the Arosa Alpine pastures. As early as 1600 those from Chur were grazing 516 cows, 66 cattle and 33 calves there, including almost one-quarter of the cattle owned by Hintersassen (socmen). The rule was that only cattle which in winter had been grazed on the Churs' Allmende were allowed to be driven to the Alpine pastures at Arosa, and the citizens were allowed to have their cattle listed one week before the socmen (Bundi 1993c: 457-462). In the mid-nineteenth century the Chur Alpine pastures at Arosa comprised a total of 353 drives on the Kuhalpen and 175 on the Galtviehalpen. On each of the four Kuhalpen the milk was jointly processed into cheese and butter, mostly for the self-subsistence of the approximately 80 Chur households entitled to driving; although cheese was stored in cellars until the cattle were driven down in autumn, butter was taken to the city every week. ${ }^{73}$ 
According to the Distribution of Assets (1875), the Chur Alpine pastures remained the property of the Corporation of Citizens; their administration and use, however, passed into the hands of the Chur municipality (see Section 6.2). Alpine agriculture experienced a commercial boom when, after Arosa was connected to the roads (1890) and railway (1914) networks - the latter being co-funded by the Corporation of Citizens and the municipality Chur - there was a rapid development of tourism. Sales market of milk multiplied at the growing spa of Arosa, and there was a growing demand for building land, which was met by the Chur Corporation of Citizens selling meadows plot by plot (Just 1907: 40-43, Maron 1934: 100, 135). Sales revenues, a result of the long-term land policy, were achieved over many decades, and transferred to the Bodenerlöskonto (Land Revenues Account) which was - in addition to the purchase of land as a real replacement for the land sold - mostly meant for funding improvements to the system of alpine agriculture. ${ }^{74}$ It was thus possible to continually invest in the modernisation of the Chur alps, which were indeed granted an award for 'exemplary' cultivation by the Alpwirtschaftlicher Verein (1946), having been granted the 'exemplary Alps' award by that same Swiss Association of Alpine Farming as early as 1864 (Giacometti 1999: 76, 90-95) (see Figure 6.8).

The spatial reorganisation of the Chur alps in Arosa has accelerated since the 1960s. With the help of investments from the Bodenerlöskonto, piped milking systems were installed at all dairies, dung water tanks with pumps and pressure lines were established to higher pastures and transportation was improved (Werthemann 1969: 208-210; Hartmann 1970: 160). The large investments

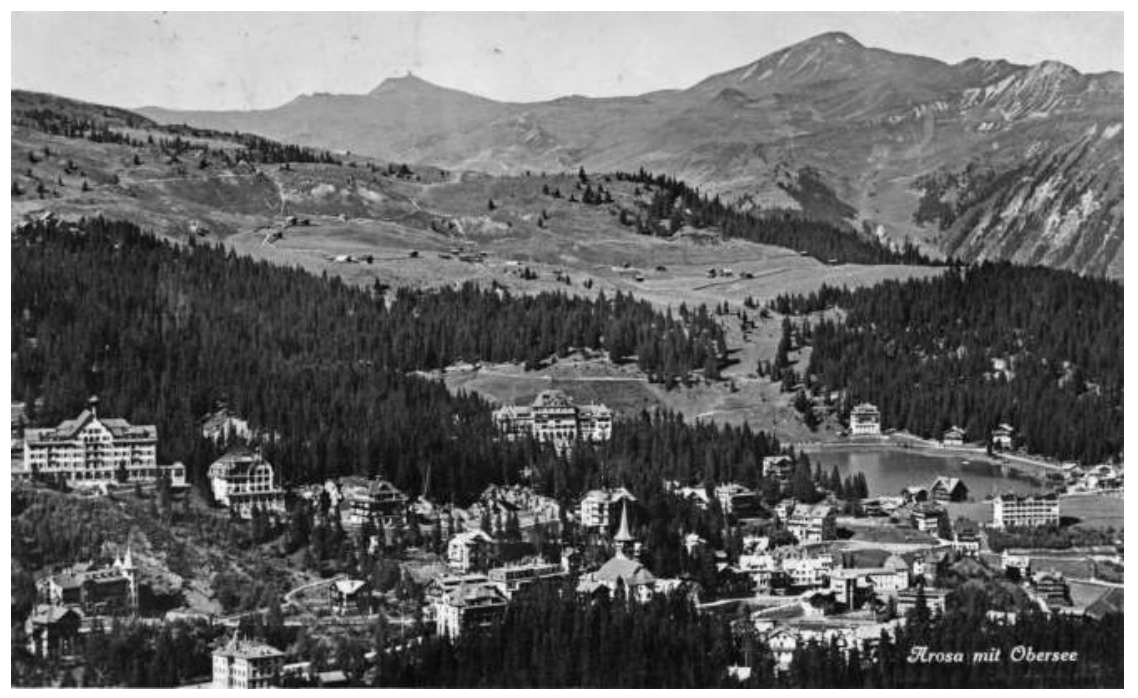

Figure 6.8 Arosa with Obersee, postcard around 1927. ETH Bibliothek Zürich, PK_006060. 


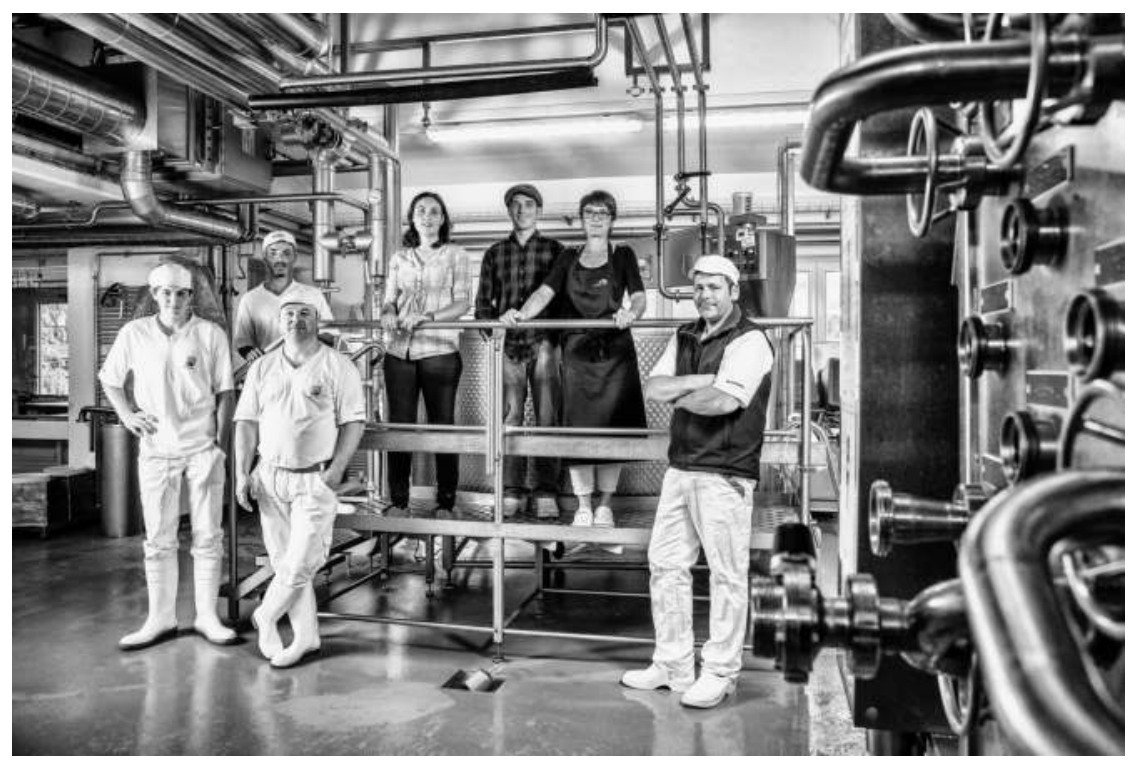

Figure 6.9 Maran Dairy Team, 2017. Foto Homberger, Arosa.

in the Maran dairy were crucial, also funded by the Bodenerlöskonto, which was connected to all four Kuhalpen via an underground milk pipeline (1967) and was extended to become a high-technology all-year milk-processing hub (2009) equipped with a cheese robot (2017) (see Figure 6.9). ${ }^{75}$ In retrospect, Toni Jäger, the head of the Woods and Alps Department of the municipality Chur, highlights the economic efficiency of this decision: 'All milk is collected at Maran. There we've got a large dairy instead of five alps with five small diaries with five infrastructures which would have to be maintained. ${ }^{76}$ This connection was a basic decision by the Chur Alps Commission, according to which the production of milk and not of meat - as the husbandry of suckler cows would be difficult to bring in line with summer tourism - can be counted on in the long run. Reto Mani, alpine farmer and Council member, reports:

Indeed, we have been considering taking one alp out of milk production and driving suckler cows on it. One problem is the potential conflict with suckler cows. After all, Arosa is very, very much a tourist area, and the alps are brutally exploited for tourism, with the hiking trail and the railway running through there. ${ }^{77}$

The Corporation of Citizens and the municipality of Chur have always had an eye on the interests of the booming tourism in Arosa. The Corporation reacted to the enormous consumption of water for the large-scale snow cannon system for artificial snowmaking by selling its water rights and spring 
tappings to the municipality of Arosa, for a onetime compensation of 3,906,000 Francs (2001). ${ }^{78}$ The Alps Commission reacted to the reduced grass growth on the Alpine pastures, resulting from the increased use of artificial snow using a refined coupling system, by purchasing hay - funded by the Bergbahnen $A G .^{79}$ The Corporation of Citizens provided pastures and compensated the Farmers' Cooperative from the Bodenerlöskonto for the realisation of a bear park as an additional tourist attraction in summer (2015). ${ }^{80}$ Chur also acted as a crucial moderator in the initially disputed realisation of the Weisshorn bike-trail (2017). ${ }^{81}$

In the context of a social-anthropologic student investigation, the complex system of the Chur Alpine pastures has been analysed for its financial and institutional dependencies (Andermatt, Freiburghaus and Koch 2019: 49-58). One important starting point is the distribution of direct payments by the Board of Agriculture and Geoinformation (Canton Grisons), paid out after a careful assessment of the framework conditions. ${ }^{82}$ The Sömmerungsbeiträge (summering fees) go to the municipality of Chur which lists them as transfer revenue in its account; the Alpungs contributions are, like the Landschaftsqualitäts- and Biodiversitätsbeiträge (environmental quality and biodiversity contributions), proportionally distributed among the farmers via the Farmers' Cooperative, one-third of the Alpungs contributions being paid to the municipality of Chur for maintenance. The grazing fee that the alpine farmers must pay to Chur per head of cattle, the administration costs which must be paid by the entirety of alpine farmers, and the wages of the alpine staff, paid for each alp individually, together comprise the costs of one alp summer. According to the Alprechnung (alp account), made by an external accountancy firm, they are contrasted with the income from milk production (amount of milk multiplied with the milk price), outsiders being paid a lower milk price than the members of the Chur Farmer's Cooperative which, running the Maran diary, bears the risk.

The efficient production of 35 tons of high-quality alpine cheese and its successful marketing is not only in the interest of the Farmers' Cooperative but also of the Corporation of Citizens and the municipality Chur. Tom Leibundgut, head of the Department of Building, Planning, Environment, gets to the heart of it: "I use to call it "my dairy", the Bürgermeister (Mayor) calls it "his diary", and the head of the Farmers' Cooperative calls it "his dairy". In a way, it's everybody's dairy. ${ }^{83}$ The integrative power of the complex system of the Chur Alpine pastures is increased by personal connections between the institutions. For example, municipality official Urs Crotta also attends the meetings of the Domains Commission of the Corporation of Citizens: 'I'm aware of what's going on, and that's very helpful.' The yearly inspections of the alps by the municipality's Alps Commission and the Corporations Domains Commission are purposefully carried out jointly. ${ }^{84}$ The Mayor of the Chur Corporation of Citizens has a seat on the Bergbahnen AG. ${ }^{85}$ According to customary law, the Bauerngenossenschaft occupy important positions with the Corporation of Citizens, namely in the Citizens Council, in the Domains Commission and as Gemeindegüterinspektoren (Corporations Property Inspectors) (Stoinescu 2018: 60). 
Despite the commercially successful production of alpine cheese and despite the investments from the Bodenerlöskonto, Chur alpine agriculture is today not self-sustaining. The revenue from touristically exploiting the alps is crucial for a positive balance: first, the concessions for the cable cars, and second, the rents from the catering businesses. Urs Crotta puts it in a nutshell: 'You know, with the help of the tourist facilities at Arosa we more or less also fund the facilities on the alps. ${ }^{86}$ However, the harmonious image of a smooth intensification of alpine agriculture and tourism has been regularly disturbed in the course of public debate in recent decades by criticism from the Heimatschutz and environmental organisations which object to large building projects on Churs' territory at Arosa, such as the Chairlift Carmenna (2000), ${ }^{87}$ Wellness Ressort Prätschli (2003-2007) ${ }^{88}$ and Summit Restaurant Weisshorn (2007). ${ }^{89}$ The roles of the Corporation of Citizens and the municipality Chur, which in this context were rather in the back seat, would require a more thorough analysis.

Research is even more required when it comes to the ecologically motivated criticism of intensified alpine agriculture, which here, with the example of manure management, has only been hinted at. In 1992 the two Chur Council members of the Demokratisch-Soziale Partei DSP demanded a ban on any kind of artificial fertiliser in the Chur Alpine pastures in Arosa, as its use would affect the alpine flora. As a consequence, the Council reduced the loan application of 8,000 Francs for artificial fertiliser by one half, which was considered a pretension by the Chur farmers: at Arosa, they claimed the use of fertilisers was moderate and only included phosphorus and potassium, which was said to be absolutely necessary to prevent the Alpine pastures from becoming overgrown; the criticism offered by laypeople was unfounded, and the farmers claimed that the current 'eco-wave' was an obvious political move. ${ }^{90}$ Reto Mani, Council member and alpine farmer, today justifies the use of fertilisers and places it into the context of intensified livestock production:

Of course, we always state our need to fertilise. It is obvious that the animals become ever more productive, so that they consume more. Cows today consumes $20 \%$ more fodder than those in the past.'

Also, he says, it is clear 'how much the flora is affected by artificial snow'. The artificial snow means that the soil is insufficiently supplied with oxygen because this kind of snow stays much longer than natural snow, and gradual soil erosion becomes noticeable. More fertiliser is thus used than in the past. This is for the Plantahof (Centre for Agricultural Education and Advice) to decide, based on ground samples sent to them. ${ }^{91}$

The goal of Chur's alpine law - 'The alps must be cultivated professionally, sustainably and in an environmentally friendly way'92 - is not integrated in all fields to the same degree. Whereas professional expertise, as well as the economic and social cornerstones of the sustainability triad, are sufficiently covered internally, the ecologic dimension seems to come from the outside and not to be integrated in the institutional system of the Chur Alpine pastures. 


\subsection{Conclusion}

Until the middle of the 19th century cattle and pasture farming were at the centre of the 'agrarian society' in Chur. This served primarily to supply the citizenry with meat and milk(-products), but was also interwoven with the transit trade (draught animals, nutrition in the guesthouses). In the forests, the aim was not only to produce wood in a regulated and sustainable manner to meet the needs of the citizen households; the forest also had to serve livestock farming in equal measure (forest pasture, forest grass, plant litter). Only the citizens had full rights of use. The Hintersassen, on the other hand, were referred to inferior wood assortments or - in the case of plant litter use - to remote forest districts. In accordance with the first Ostrom principle (see Chapter 2), this can be seen as a clear demarcation between those entitled and those not entitled. On the other hand, there is a negative balance if social justice - an indispensable component of our current understanding of sustainability - is taken as an assessment criterion. The verdict on political participation (third Ostrom principle) is also negative, from which not only the Hintersassen were excluded, but also the majority of the citizens. In contrast, the Allmende appears to be a more integrative system of use. Regulation was not carried out by the Council, but by the two sub-communities and the guilds. There were also compensation areas at lower altitudes towards the Rhine, the cultivation of which offered opportunities especially for poorer families. The intensively used favoured sites were increasingly privately owned but were temporarily left open for collective grazing. In addition, the acquisition of the Chur Alpine pastures decisively expanded the collective resource base.

In the incipient 'industrial society', the operating objective of collective resources shifted to the maximum sustainable yield (financial return). In the Chur forests, the focus was narrowed to sustainable timber production, which was professionalised and spatially homogenised. In contrast, the circle of users was expanded, in that the forests remained the property of the Corporation of Citizens at the time of the constitution of the municipal dualism (1875), but the rights of use were transferred to the newly created municipality, for whom they henceforth represented an important financial resource. The inclusion of the entire population abolished the first Ostrom principle of a clear border; at the same time, all those affected, as postulated by the third Ostrom principle, were able to participate. On the Chur Allmende, the Gemeinatzung was abolished and the small plot structure of the Bürgerlöser was transformed into coherent leased land suitable for mechanical processing. In Arosa, the tourist boom was accompanied by the purchase of building land to finance the modernisation of the alpine economy.

As the 'consumption society' was unable to keep up with the rising costs of timber production, government support payments for the maintenance of protection forests became the most important source of income. Recreational and natural values also came to the fore. There is an attempt to mitigate the decreasing understanding of wood use in the urban milieu through environmental education and political communication. The centuries-old forest property 
of the citizens and the tradition of Bürgerholz (citizen wood) play a role that should not be underestimated, at least on an emotional level. However, this by no means eliminates the fundamental deficit of participation of all persons affected by a resource system (Ostrom's third principle). In the management of the Chur Alpine pastures, however, there is a deficit in the sustainability triangle. While highly technical cheese production implies economic success and the symbiosis of alpine economy and tourism satisfies the social cornerstone, the ecological dimension still seems to be somewhat left out.

The answer to the initial question about the role of topography in the longterm perspective is ambivalent. The specific spatial conditions of Chur provide a decisive framework for the transformation of citizenship and its collective resources in many respects. Examples include the geographical position of Chur, which is conducive to transit trade, or the rising slopes on the flanks, which are causally related to the protection of forest payments. It also became clear how the topographic conditions can have a different effect, particularly by means of new transport infrastructure (road, rail, pipeline), which in turn is linked to the different energy ages. Collective resources and their spatial arrangement are not static variables but are transformed in changing contexts.

\section{Acknowledgement}

I would like to thank all the actors in Chur who made themselves available for a longer interview and who, in addition, helped me in many ways to understand the Bürgermeinde Chur: Ruth Bianchi, Marco Caduff, Urs Crotta, Toni Jäger, Reto Mani, Martin Studer; all those who read parts of the manuscript and gave me important feedback: Matthias Bürgi, Georg Jäger, Ulf Wendler; the staff of the Staatsarchiv des Kantons Graubünden, the Stadtarchiv and the Archiv der Bürgergemeinde; Mirko Wittwar (Morsbach) for the careful translation of this chapter.

\section{Notes}

1 All quantitative data refer to 2019, i.e. immediately before the incorporation of Haldenstein and Maladen.

2 Website of the Chur Corporation of Citizens: https://die-buergergemeinde.ch/; website of the City of Chur: https://www.chur.ch/naturwaldstadtgruen/308; website of the Bürgerverein https://der-buergerverein.ch/;VB BG 2019; Giacometti 1999; Fuchs 2011; Simonett 2015; Andermatt, Freiburghaus and Koch 2018: 30; Gesetz über die Bewirtschaftung der Churer Alpen (Alpgesetz), 2005, https://www.chur.ch/rechtssamm lung/sammlung99116086.

3 Interview with Martin Studer, 14.3.2018 (M. Stuber).

4 Interview with Ruth Bianchi, 2.2.2018 (M. Stuber).

5 Verwaltungsberichte der Bürgergemeinde Chur under various headlines, in the following quoted as $V B B G$ :

- Verwaltungsrechnung undVermögensstand der bürgerlichen Armen- \& Waisenanstalt [1879]

- Bericht über die Bürgerliche Verwaltung, sammt Inventar der Armenpflege [1885]

- Verwaltungsbericht samt Jahresrechnung der Bürgerlichen Armenpflege [18871939] 
- Verwaltungsbericht mit Jahresrechnung der Bürgerlichen Verwaltung Chur [19401974]

- Verwaltungsbericht, Bürgergemeinde Chur [1984-].

6 Verwaltungsberichte der Stadt Chur under various headlines, in the following quoted as VB Stadt:

- Verwaltungsbericht samt Jahresrechnung der Stadt Chur [1885-1960]

- Verwaltungsbericht und Jahresrechnung der Stadt Chur [1961-1977]

- Verwaltungsbericht der Stadt Chur [1978-2000]

- Verwaltungsbericht des Stadtrates Chur [2001 ff.]

7 The various traditions are to be found in: Bruggmann 2017: 215-227.

8 [Christ, Ludwig] 1838. Was braucht die Bürgerschaft von Chur und was braucht sie nicht. Ein Wort zur Beherzigung für solche die noch athmen dürfen. Chur, here: 6/7, 20/21. Stadtarchiv Chur.

9 Verfassung für die Stadt Chur:Vom 10. Juni 1840. Chur. Stadtarchiv Chur.

10 Plan über den Einkauf in das Bürgerrecht der Stadt Chur. 9. Juli 1835. Stadtarchiv Chur.

11 Ausschreiben nebst Vorschlag eines Gesetzes über den Einkauf in das Bürgerrecht der Stadt Chur, 28. April 1845 (after Giacometti 1993: 100).

12 Bürgermeister und Rath, 30. Juni 1866. Stadtarchiv Chur.

13 Caduff,Julius:Die Einwohner-Gemeinde. Ein Beitrag zum schweiz. Staats- \& GemeindeRecht. Senti \& Hummel: Chur 1864.

14 Bürgermeister und Rath der Stadt Chur an die Löbl. Bürgerschaft derselben, 30.6.1866. Stadtarchiv Chur.

15 Bauer, Peter Jakob: Betrachtungen und Ansichten über die Churer Gemeindwirren, Bündnerische Volks-Zeitung, 4.3.1868, after Bundi 2016: 83.

16 Bürgermeister und Rath der Stadt Chur an die Löbliche Bürgerschaft derselben, 9.4.1870. Stadtarchiv Chur.

17 Gesetz über die Niederlassung von Schweizerbürgern, 1.9.1874.

18 Bürgermeister und Rath der Stadt Chur an die löbl. Bürgerschaft derselben, 30.4.1875. Stadtarchiv Chur BB III, 01.041.002; see: Ausführungsbestimmungen zu dem von der Bürgerversammlung am 11.4.1869 angenommenen Tilgungsplane der städtischen Schulden, genehmigt vom Grossen Stadtrath den 17.8.1869. Stadtarchiv Chur;VB Stadt 1869.

19 Bürgermeister und Rath an die löbliche Einwohner-Gemeinde der Stadt Chur, 7.7.1875, Vermögenstand der Stadt Chur, pro 1. Januar 1875. Stadtarchiv Chur.

20 Verwaltungsreglement für die Bürgerschaft, beschlossen in der Bürgergemeinde am 29. April 1923. Nationalbibliothek Bern.

21 Statuten der Bürgergemeinde Chur 2014, https://die-buergergemeinde.ch/wp-conten t/uploads/2018/10/statuten-der-buergergemeinde-chur-in-kraft-seit-01.12.2014.pdf; see VB BG 2014: 2.

22 Interview with Martin Studer, 14.3.2018 (Martin Stuber).

23 Interview with Martin Studer, 14.3.2018 (M. Stuber).

24 Interview with Ruth Bianchi, 2.2.2018 (M. Stuber).

25 Interview with Reto Mani, 1.2.2018 (M. Stuber / A. Stoinescu); Interview with Ruth Bianchi, 2.2.2018 (M. Stuber); Interview with Urs Crotta, 4.8.2018 (M. Stuber / I. Brändli).

26 VB BG 1983: 9-10; siehe z.B. auch VB BG 1982: 9; Bündner Zeitung, 1.7.1993: 5: Genereller Einbürgerungsstopp nach neuem Bürgerrechtsgesetz unhaltbar; Bündner Tagblatt, 5.11.1996: 1: Einbürgerung: 4 Gesuche von Ex-Jugoslawen abgelehnt; Bündner Zeitung, 20.4.1999: 9: Dem Unmut Luft gemacht? Die Churer Bürger verweigern Türken und Ex-Jugoslawen die Einbürgerung.

27 Bundesgerichtsentscheid 129/217, Urnenabstimmung Emmen, https://www.servat.u nibe.ch/dfr/c1129217.html [11.8.2020].

28 VB BG 2004: 1.

29 VB BG 2001: 1.

30 VB BG 2009: 1-2; siehe z.B. Südostschweiz, 4.10.2010: Khur - die Stadt meins Herzens (Verena Zimmermann). 


\section{Martin Stuber}

31 VB BG 2019:23.

32 Gemeindegesetz des Kantons Graubünden. Vom Volke angenommen am 28.4.1974. In: Amtliche Gesetzessammlung des Kantons Graubünden, 1971-1975. Chur 1977: 541-561.

33 Gemeindegesetz des Kantons Graubünden, vom 17.10.2017 https://www.gr-lex.gr.ch/ app/de/texts_of_law/175.050.

34 Schlussbericht der Arbeitsgruppe ALÜ betreffend Auftrag Nr. 13 (Bürgergemeinde), 2013 https://www.chur.ch/_docn/950092/Schlussbericht_Arbeitsgruppe_ALU_Auft rag_13.pdf; siehe VB BG 2013: 2 .

35 Interview mit Martin Studer, 14.3.2018 (M. Stuber).

36 Interview mit Marco Caduff, 20.6.2017 (M. Stuber).

37 Interview mit Reto Mani, 1.2.2018 (M. Stuber / A. Stoinescu).

38 VB BG 2019: 3 .

39 A first outline of this Section 6.3 was presented at Schweizerische Geschichtstage, Zürich, 5.-7. June 2019: Panel L'or vert des Alpes (Luigi Lorenzetti). For valuable comments on the first draft of the manuscript I am obliged to Urs Crotta, Georg Jäger, Toni Jäger, Martin Studer (all Chur) and Matthias Bürgi (WSL Birmensdorf). A German version wil be published in Schweizerische Zeitschrift für Forstwesen SZF.

Forst- und Waldordnung, Löbl. Stadt Chur (1791). Chur: Otto.

40 Forst- und Waldordnung, Löbl. Stadt Chur (1791). Chur: Otto.

41 Grund-Riss der Underthorer Waldung Löbl. Stadt Chur (1788). Stadtarchiv Chur, E-0655.

42 Forstordnung (1839). In Amtliche Gesetzessammlungen für den Eidgenössischen Stand Graubünde,Vol. 3, Chur 1840: 211-219.

43 See the analogous regulations in: Bekanntmachung Losholz, 1845. Stadtarchiv, Chur BD IV / 1.5033.

44 Vorschlag der Obrigkeit der Stadt Chur an die löbliche Bürgerschaft derselben zu einem Gesetz über die Benutzung der Stadtwaldungen (1845). Stadtarchiv Chur.

45 Forstpolizeiordnung für die Waldungen der Stadt Chur (1846). Stadtarchiv Chur.

46 Bericht über die Landesverwaltung des Kantons Graubünden (1851/1852). Chur: Druckschriften- und Lehrmittelverlag Graubünden: 9; see: Amtsbericht des Kantonalen Forstinspektors an den Hochlöblichen Grossen Rath, 1856/1857: 135, 142-143..

47 It is only possible to hint here at how much Chur's forest economy was interwoven with the then new Canton and national forest policy; see Schuler 2018;Viallon, Liechti, Stuber, and Wunderli 2019: 130-135.

48 On the embedding in the history of knowledge see Mantel 1990: 378-408; Cronjäger (forthcoming).

49 Nationally renowned forestry experts also contributed to the revisions of Chur's forestry plans: 1865 (Coaz, Kopp), 1877 (Landolt, Kopp), 1887 (Landolt).

50 Forstordnung der Stadtgemeinde (1886). Stadtarchiv Chur.

51 Revidirte Forstordnung (1877). In Amtliche Gesetzessammlung des Kantons Graubünden, Vol. 4, Chur 1880: 193-207.

52 Auszug aus dem Wirtschaftsplan für die Heimwaldungen der Stadt Chur (1907). Chur: Manatschal Ebner.

53 VB Stadt 1956: 18

54 VB Stadt 1958: 15.

55 VB Stadt 1966: 33.

56 VB Stadt 1975: 67.

57 VB Stadt 1988: 57.

58 Interview with Toni Jäger, 2.2.2018 (M. Stuber / A. Stoinescu), appendix, 27.12.2019.

59 Interview with Toni Jäger, 2.2.2018 (M. Stuber / A. Stoinescu).

60 Waldgesetz der Stadt Chur. Beschlossen in derVolksabstimmung of October 24th, 1999, online-version, https://www.chur.ch/_docn/397714/561.pdf (last access 6 March 2020).

61 Betriebsplan Chur Heimwald 2004-2023. 
62 VB Stadt 2006: 86.

63 After Churer Magazin 2010, 5: 4-5: Der Churer Wald befindet sich in besten Händen (Peter de Jong); siehe: Umwelt. Natürliche Ressourcen in der Schweiz 2013, 1: 41-45: Schutzwald - Waldpflege für die Sicherheit (Urs Fitze), online-version, www.bafu.a dmin.ch/bafu/de/home/themen/wald/dossiers/schutzwald-waldpflege-sicherheit. html (last access 6 March 2020).

64 Interview with Martin Studer, 14.3.2018 (M. Stuber).

65 Interview with Urs Crotta, 4.9.2018 (M. Stuber / I. Brändli).

66 Interview with Urs Crotta, 4.9.2018 (M. Stuber / I. Brändli).

67 Interview with Martin Studer, 14.3.2018 (M. Stuber).

68 Interview with Urs Crotta, 4.9.2018 (M. Stuber / I. Brändli).

69 A more detailed version of this Section 6.4 is in preparation for the special issue «Tiere und Pflanzen im urbanen Raum. Mensch-Umwelt-Interaktionen vom Spätmittelalter bis zum Beginn der Industrialisierung», forum Stadt 2021.

70 See Pläne in Betreff der ausgetheilten Gemeindsgütern unter die löbl. Bürgerschaft der Stadt Chur, 1765 und 1794. Chur 1795; Allgemeine Gemeindegüter-Ordnung der Stadt Chur. Chur 1823; Bericht und Gutachten der von einem wohl. Stadtrath und den löbl. Zünften wegen Urbarmachung und Verwendung des noch unangebauten Gemeindsbodens bestellten Commission. Chur 1839.

71 Weidgangs- und Allmeinden-Ordnung löbl. Stadt Chur wie solche durch die mehren löbl, Zünfte vom 25 April 1828 zum Gesetz erhoben worden ist. Kantonsbibliothek Graubünden.

72 Schweizer Bauer, 12.08.2015: 9: Älpler und Touristen brauchen einander. Die Churer Alpen in Arosa sind ein Aushängeschild der Bündner Alpwirtschaft (Daniel Salzmann).

73 Die Alpen der Stadt Chur. In: Schweizerische Alpwirtschaft, Heft 5, 1864: 59-81.

74 Established as Alpverbesserungskonto (Alps Improvement Account) in 1894, renamed Bodenerlöskonto (Land Revenue Account) in 1906.

75 Aroser Zeitung, 16.6.2017: 6-7: Sennerei Maran auf neuestem Stand (Christian Jenny); Interview with Urs Crotta, 4.9.2018 (M. Stuber / I. Brändli).

76 Interview with Toni Jäger, 2.2.2018 (M. Stuber / A. Stoinescu).

77 Interview with Reto Mani, 1.2.2018 (M. Stuber / A. Stoinescu).

78 Aroser Zeitung, 16.2.2001: 11: Churer Wasserversorgungsanlagen an Arosa (Christian Jenny); VB Stadt 2001:32; Interview with Toni Jäger, 2.2.2018 (M. Stuber / A. Stoinescu).

79 Aroser Zeitung, 9.7.2010: 1-3: Schanfigger Alpwirtschaft ist in guterVerfassung (Christian Jenny). Interview with Reto Mani, 1.2.2018 (M. Stuber / A. Stoinescu).

80 Interview with Urs Crotta, 4.9.2018 (M. Stuber / I. Brändli); Interview with Toni Jäger, 2.2.2018 (M. Stuber / A. Stoinescu).

81 Interview with Toni Jäger, 2.2.2018 (M. Stuber / A. Stoinescu).

82 Amt für Landwirtschaft du Geoinformation ALG. 2020. Sommerungsbeiträge 2020. https://www.gr.ch/DE/institutionen/verwaltung/dvs/alg/dokumentation/agrarma ssnahmen/Dokumentliste\%20Agrarmassnahmen/Weisungen_Soemmerungsbeitraege _de.pdf\#search $=$ s\%C3\%B6mmerungsbeitr\%C3\%A4ge.

83 After Stoinescu 2018: 66.

84 Interview with Urs Crotta, 4.9.2018 (M. Stuber / I. Brändli)

85 Interview with Urs Crotta, 4.9.2018 (M. Stuber / I. Brändli).

86 Interview with Toni Jäger, 2.2.2018 (M. Stuber / A. Stoinescu); see Aroser Zeitung, 9.3.2007: 5: Bodengeschäfte in Arosa. Aus den Verhandlungen des Bürgerrates der Bürgergemeinde Chur (Norbert Waser).

87 Aroser Zeitung, 12.5.2000: Sesselbahnprojekt Carmenna / Plattenhorn (WWF Graubünden, Pro Natura Graubünden).

88 E. g. Aroser Zeitung, 30.1.2004: 1: Die Meinungen gehen weit auseinander. Informationsabend Überbauung Prätschli (Peter Lüscher); Beobachter. 14.3.2005: Hotelprojekt: Auf der Alm, do gibt's koa Bausünd (Thomas Buomberger). https:// 


\section{Martin Stuber}

www.beobachter.ch/burger-verwaltung/hotelprojekt-auf-der-alm-do-gibts-koa-bau sund; Aroser Zeitung, 2.3.2007: Gastkommentar - Entgegnung des WWF auf unseren Kommentar (Anitta Mazzetta).

89 Aroser Zeitung, 19.10.2007:Das Bundesgericht muss endgültig entscheiden (Peter Lüscher).

90 Bündner Zeitung,25.4.1992:Arosa:ChurerDSP-Gemeinderäte fordern Kunstdüngerverbot auf Churer Alpen.

91 Interview mit Reto Mani, 1.2.2018 (M. Stuber / A. Stoinescu).

92 Gesetz über die Bewirtschaftung der Churer Alpen (Alpgesetz), 2005. https://www.chu r.ch/rechtssammlung/sammlung/116086.

\section{References}

Andermatt, P., Freiburghaus, L. and Koch, M. 2019. Die Kollektivbewirtschaftung der Churer Alpen in Arosa. Untersuchung der Robustheit eines Allmendressourcen-Managementsystems aus der emischen Perspektive. Bern: Bachelorarbeit Sozialanthropologie Universität.

Blickle, P. 2011. Kommunalismus und Republikanismus revisited. Graubünden als paradigmatischer Fall. In Gemeinden und Verfassung. Bündner Politik und Gebietsstruktur gestern, heute, morgen, edited by Hitz, F., Rathgeb, C. and Risi, M., Chur/Glarus: Südostschweiz Buchverlag, pp. 13-34.

Brändli, I. 2019. Die Bürgergemeinde Chur. Aus der Zeit gefallen und doch beständig. Eine Untersuchung mit Schwergewicht auf den Jahresrechnungen und -berichten unter Einbezug der Korporation Uri. Zürich: Masterarbeit Universität.

Bruggmann, T. 2017. Wachsendes Selbstbewusstsein und zunehmende Verschriftlichung - Churer Quellen des 15. Jahrhunderts. Quellen und Forschungen zur Bündner Geschichte, Bd. 35. Chur: Kommissionsverlag Desertina.

Buchmann, W. 1977. Schweizer Bürgergemeinden als Landschafts-Aktoren: ihr Grundeigentum und dessen aktuelle Entwicklung am Beispiel von Bern, Chur und Solothurn. Basel.

Bühler, L. 1993a. Die Bischofsstadt. In Churer Stadtgeschichte, edited by Jecklin, U., Chur: Verlag Bündner Monatsblatt, Bd. 1. pp. 219-224.

Bühler, L. 1993b. Stadtbild. Wirtschaft und Bevölkerung bis zum beginnenden 14 . Jahrhundert. In Churer Stadtgeschichte, edited by Jecklin, U., Chur: Verlag Bündner Monatsblatt, Bd. 1. pp. 225-265.

Bühler, L. 2015. Chur (Gemeinde). 450 bis ca. 1450. In Historisches Lexikon der Schweiz HLS. https://hls-dhs-dss.ch/de/articles/001581/2015-11-18/.

Bundi, M. 1993a. Aussehen, Bevölkerung, Erwerbszweige. In Churer Stadtgeschichte, edited by Jecklin, U., Chur: Verlag Bündner Monatsblatt, Bd. 1. pp. 266-323.

Bundi, M. 1993b. Chur in seinen Beziehungen zu den Drei Bünden und nach aussen. In Churer Stadtgeschichte, edited by Jecklin, U., Chur: Verlag Bündner Monatsblatt, Bd. 1. pp. 356-381.

Bundi, M. 1993c. Wirtschaftliche, soziale und politische Entwicklung bis ungefähr 1640. In Churer Stadtgeschichte, edited by Jecklin, U., Chur: Verlag Bündner Monatsblatt, Bd. 1. pp. 451-493.

Bundi, M. 2015. Chur (Gemeinde). Vom Spätmittelalter bis zur Mitte des 17. Jahrhunderts. In Historisches Lexikon der Schweiz HLS. https://hls-dhs-dss.ch/de/articles/001581/2015-11-18/.

Bundi, S. 2016. Gemeindebürger, Niedergelassene und Ausländer. Eine Bündner Abgrenzungsgeschichte 1874-1974. Baden: hier und jetzt.

Casti, J.B. 1971. Monographie über Arosa. 3 Bde. Arosa: Gemeinde Arosa.

Cronjäger, L. (forthcoming). Bäume für das neue Jahrtausend. Die Vorstellung einer genauen und nach haltigen Ressourcenverwaltung. 
Curschellas, J.M. 1926. Die Gemeinatzung. Ilanz: Moriz Maggi’s Erben.

Forst- und Alpverwaltung der Stadt Chur (2003). Betriebsanalyse zur Anpassung der Forst- und Alpverwaltung an die veränderten Ansprüche. Projektbericht. Chur: abenis AG.

Ernst, C. 2000. Forstgesetze in der Frühen Neuzeit. Zielvorgaben und Normierungsinstrumente für die Waldentwicklung in Kurtrier, dem Kröver Reich und der Hinteren Grafschaft Sponheim (Hunsrück und Eifel). In Policey und frühneuzeitliche Gesellschaft, edited by K. Härter. Frankfurt a.M.: Vittorio Klostermann, pp. 341-381.

Fuchs, K. 2011. Chur. Historischer Städteatlas der Schweiz. Zürich: Chronos.

Gerber, J.-D. 2008. Les strategies foncières des grands propriétaires collectifs: Le cas des bourgeoisies de Berne, Soleure et Croire. Chavannes-près-Renens: Working paper de l'IDHEAP.

Giacometti, E. 1999. Die Bürgergemeinde Chur: ihre Entstehung, ihre Entwicklung und ihre Aktivitäten bis heute. Chur: Bürgergemeinde.

Grüne, N., Hübner, J. and Siegl, G. (eds.) 2016. Ländliche Gemeingüter. Kollektive Ressourcennutzung in der europäischen Agrarwirtschaft. Rural Commons. Collective Use of Resources in the European Agrarian Economy. Innsbruck: Studienverlag.

Hartmann, J. 1970. Land- und Forstwirtschaft der Stadt Chur. In Chur. Sammlung Städte und Landschaften der Schweiz. Genf: Benjamin Laederer, pp. 157-170.

Hilfiker, M. 1993. Chur im 17. und 18. Jahrhundert: Gesellschaft, Wirtschaft, Politik. In Churer Stadtgeschichte, edited by Jecklin, U., Chur: Verlag Bündner Monatsblatt, Bd. 2. pp. 13-66.

Hilfiker, M. 2015. Chur (Gemeinde). Von der Mitte des 17. Jahrhunderts bis zur Helvetik. In Historisches Lexikon der Schweiz HLS. https://hls-dhs-dss.ch/de/articles/001581/201 5-11-18/.

Hitz, F., Rathgeb, C. and Risi, M. (eds.). 2011. Gemeinden und Verfassung. Bündner Politik und Gebietsstruktur gestern, heute, morgen. Chur/Glarus: Südostschweiz Buchverlag.

Jäger, G. 2000. Graubündens Integration in der Schweiz. In Handbuch der Bündner Geschichte, edited by Verein für Bündner Kulturforschung, Bd. 3, pp. 312-328.

Jecklin, U. (ed.). 1993. Churer Stadtgeschichte, 2 Bde. Chur: Verlag Bündner Monatsblatt.

Jecklin, U. 1993a. Zunftgründung und Zunftentwicklung. In Churer Stadtgeschichte, edited by Jecklin, U., Chur: Verlag Bündner Monatsblatt, Bd. 1. pp. 303-355.

Jecklin, U. 1993b. Niedergang der Zunftherrschaft und Beginn der Gewerbefreiheit. In Churer Stadtgeschichte, edited by Jecklin, U., Chur: Verlag Bündner Monatsblatt, Bd. 2. pp. 121-172.

Just, R. 1907. Die Gemeinde Arosa: Ihr Wirtschaftsleben vor und seit dem Fremdenverkehr. Zürich: J. Leemann, vormals J. Schabelitz.

Mantel, M. 1990. Wald und Forst in der Geschichte. Ein Lehr- und Handbuch. Hannover: M.H. Schaper.

Maron, F. 1934. Vom Bergbauerndorf zum Weltkurort Arosa. Chur: Verlag F. Schuler.

Metz, P. 1991. Die Aufhebung der Churer Zunftordnung. Bündner Jahrbuch 33: 14-18.

Mohr, G.R. 1953. Verfassung und Verwaltung der Stadtgemeinde Chur. In Churer Stadtbuch. Chur: Bischofberger \& Co., pp. 101-136.

Moll, D. 2020. Räumliche Rekonstruktion der Bodenpolitik der Bürgergemeinde Chur. Handänderungen, Baurechtsvergaben und Bauprojekte seit 1875. Bern: Seminararbeit Historisches Institut Universität.

Moosberger, H. 1891. Die Bündnerische Allmende. Chur: Chr. Senti.

Passini, F. 2004. Die bündnerische Gemeinatzung. Ein Überrest des früheren Gemeineigentums. Zürich: Dissertation Univ.

Pieth, F. 1951. Der Wald in der bündnerischen Kulturgeschichte. Bündnerisches Monatsblatt 44-52; 65-81. 


\section{Martin Stuber}

Pieth, F. 1953. Ein Blick in die Vergangenheit der Stadt. In Churer Stadtbuch. Chur: Bischofberger \& Co., pp. 27-83.

Plüss, D. 2020. Die Gemeindegüter der Bürgergemeinde Chur vom ausgehenden 18. Jahrhundert bis heute. Bern: Bachelorararbeit Historisches Institut Universität.

Sablonier, R. 2000. Politik und Staatlichkeit im spätmittelalterlichen Rätien. In Handbuch der Bündner Geschichte, edited by Verein für Bündner Kulturforschung, Bd. 1, pp. 245-291.

Schorta, A. 1942. Das Landschaftsbild von Chur im 14. Jahrhundert, eine Flurnamenstudie. Genf: Librairie E. Droz; Zürich: Eugen Rentsch.

Schuler, A. 2018. Forstliches Wirken von Coaz. In Coaz, Pionier seiner Zeit (1822-1918). Jubiläumsausgabe Bündner Wald 17, Juli: 26-31.

Schuler, F. 2011. Die Entwicklung des Bündner Gemeindewesens im 20. Jahrhundert. In Gemeinden und Verfassung. Bündner Politik und Gebietsstruktur gestern, heute, morgen, edited by Hitz, F., Rathgeb, C. and Risi, M. (eds.). Chur/Glarus: Südostschweiz Buchverlag, pp. 135-154.

Simonett, J. 2015. Chur (Gemeinde). Von der Helvetik bis zur Gegenwart. In Historisches Lexikon der Schweiz HLS. https://hls-dhs-dss.ch/de/articles/001581/2015-11-18/.

Spinatsch, J. 2005. Der Waldfrevel in Chur zwischen 1750 und 1840. Eine Studie über das interaktive Konfliktpotential des Waldes während der Übergangszeit vom Ancien Régime in eine neue Gesellschaft. Zürich: Lizentiatsarbeit Univ.

Stoinescu, A. 2018. Optimierung der Wirtschaftlichkeit von Alpweiden durch kooperatives Management. Eine qualitative Forschung in Schweizer Gemeinden. Zürich: Masterarbeit Ethnologie Universität.

Stuber, M. 2020. Vom Versorgungswald zum Försterwald - die «Oberaufsicht über die Forstpolizei» in der Longue durée. In Umweltpolitik in der Schweiz. Von der Forstpolizei zur Ökobilanzierung, edited by H.A. Mieg and U. Haefeli. Basel: NZZ Libro, pp. 34-53.

Stuber, M. and Bürgi, M. 2012. Hüeterbueb und Heitisträhl. Traditionelle Formen der Waldnutzung in der Schweiz 1800-2000. Bern, Stuttgart, Wien: Haupt (2. Aufl.).

Töndury, O.A. 1949. Der Finanzhaushalt der Stadt Chur in seiner Entwicklung. Chur: Bischofberger.

Viallon, X.-F. Liechti, K., Stuber, M. and Wunderli, R. 2019. Vermittlung, Einbau, Komplementarität - Formen des staatlichen Zugriffs auf kollektive Weiden und Wälder in der Schweiz im späten 19. Jahrhundert. In Kollektive Weiden und Wälder. Ökonomie, Partizipation, Nachhaltigkeit, edited by A.-L. Head-König, L. Lorenzetti, M. Stuber, and R. Wunderli (Geschichte der Alpen - Histoire des Alpes - Storia delle Alpi, Bd. 24), Zürich: Chronos, pp. 125-149.

Waldungen der Stadt Chur. 1953. In Churer Stadtbuch. Chur: Bischofberger \& Co., pp. $163-168$.

Wendler, U. 2015. Das Churer Zunftregiment: die städtische Zunftverfassung in der zeitgenössischen Literatur. Bündner Monatsblatt: Zeitschrift für Bündner Geschichte, Landeskunde und Baukultur 1: 28-57.

Wendler, U. 2018. Reform und Weiterentwicklung, Die Churer Zunftverfassung von 1577. Jahrbuch der Historischen Gesellschaft Graubündens: 37-77.

Werthemann, A. 1969. Schweizerischer Alpkataster. Kanton Graubünden. Teil 1. Bern: Abteilung für Landwirtschaft EVD. 


\title{
7 Transformation, diversification, partnerships
}

\author{
The case of the Sarnen commoners' \\ organisations (Canton Obwalden)
}

Karina Liechti

\subsection{Introduction}

This chapter analyses transformational change in the four commoners' organisations (or corporations, also called Korporationen, or formerly Teilsamen) of Sarnen in the Swiss canton of Obwalden. It shows that these commoners' organisations have not only adapted to a changing societal, political and economic environment, but have transformed themselves in order to remain important players in the local context. It additionally points out that due to the diverse structures of the four corporations, they are more or less resilient or vulnerable to change. When acting collectively and by positioning themselves as reliable partners, the Sarnen corporations are providing locally adapted and grounded means of dealing with contemporary ecological and societal challenges and are thus able to contribute to sustainable development.

The chapter is structured as follows. After a brief first section on the methods used, the second outlines the spatial characteristics of the region. The third section deals with the institutional context and the history of the Sarnen corporations, from their proven existence in the fourteenth century up to the mid-twentieth century. The fourth and most elaborate section deals with the last half-century and is structured based on an adapted version of Ensminger's model of institutional change (1992: 10). The model encompasses the interaction between external change and internal transformations within a social group and provides a suitable tool to categorise and analyse dynamics in socialecological systems. It assumes that external factors in the realms of policies, economy or society transform relative prizes of resources. These changes then impact the internal change of a local system, affecting the bargaining power of actors, their organisation, the institutions they select and the ideology they use to legitimise their actions and institutional choices. In turn, changes in internal factors shape the meaning that is attributed to external changes (via relative prices) and thus constitute adaptive and proactive coping strategies, apparent in common social, political and economic actions. In the last section - the conclusions - the results are synthesised with reference to the corporations' vulnerabilities and resiliencies. 


\subsection{Methods}

The empirical material presented in this chapter is based on a literature review, document analysis (e.g. regarding corporation regulations), analysis of annual financial reports, participant observation and qualitative interviews. The main part of the investigation was composed of semi-structured qualitative expert interviews that comprised aspects of narrative and focused interviews (Flick et al. 2004). By combining open questions at the beginning with an increasing focus on specific issues towards the end of each interview, it was possible not only to acquire new and unexpected insights but also to elicit specific responses on certain topics, making it possible to establish comparisons with similar kinds of answers from other respondents. The respondents were selected according to background (and thus potential to contribute to the research topic) and the focus was put on representatives of the corporations and other relevant organisations (i.e. canton, municipality, associations, non-governmental organisations). The main empirical data presented here are based on narratives supplied by 25 people across 21 interviews. The interviews ranged from 1.5 to 2.5 hours in length and were recorded and transcribed verbatim, with the exception of conversations in the field. The topics addressed included economic functions of common property, interlinkages between political levels, land and forest use, self-organisation, knowledge and identity. The transcribed interviews were analysed with predefined analytical categories that were subsequently regrouped into broad thematic complexes, which are discussed below. Participatory observation was used during the following events: participation in annual corporation assemblies; field surveys with corporation representatives; and participation in the traditional semi-annual reunion (Halbjahreskilchgang) of the Sarnen corporations' council members. In the middle and at the end of the research project, the research results were discussed with corporation representatives in group or individual meetings.

\subsection{Spatial characteristics of the region}

The canton of Obwalden is located in central Switzerland and is part of the Prealps region. It has an area of around 50,000 ha. Of this, around 20,000 ha or $40 \%$ is covered by forest (Lienert 2010). The agriculturally usable area amounts to about 19,000 ha, $60 \%$ of which comprises alpine pastures (Kanton Obwalden 2020). Six of the seven municipalities of Obwalden are located in the main valley, the Sarneraatal, while the municipality of Engelberg represents an exclave. Obwalden's landscape has no harsh contrasts and, with the exception of the Melchtal valley, which is the only major junction, is quite scenic due to the gentle waves of its hills and mountains (Lienert 1981a: 485). The Sarneraatal is characterised by three large lakes and a multitude of watercourses and several side valleys. The upper limit of settlement is on north-west slopes at 900 metres above sea level and on sunny slopes at 1,100 metres above sea level. At higher altitudes there are alpine pastures and wooded areas (Lienert 
\& Wallimann 1963). The summering area in the canton of Obwalden begins at around 1,000 $\mathrm{m}$ above sea level and extends to around 2,200 $\mathrm{m}$ above sea level. Generally, the alpine pastures have good grazing potential for dairy cows. However, in the flysch ${ }^{1}$ area between Giswilerstock and Pilatus, where the alpine pastures are wet, only medium to poor fodder grows. These alps (summering pastures) are preferentially stocked with young cattle and occasionally with suckler cows (Abächerli et al. 2004). On the other hand, this flysch area hosts one of Switzerland's most impressive mire landscapes, ${ }^{2}$ today's protected Glaubenberg mire landscape (municipalities of Sarnen, Giswil, Alpnach).

The case study region - the municipality of Sarnen - is the cantonal capital and has 10,453 inhabitants. Its main settlement area - the town of Sarnen lies in the lowland on Lake Sarnen at $473 \mathrm{~m}$ above sea level. Other important Sarnen settlements are Stalden, Wilen, Kägiswil and Ramersberg (Figure 7.1). About $56 \%$ of the municipal area is owned by four corporations: Freiteil (Sarnen), Schwendi (Stalden and Wilen), Kägiswil and Ramersberg (Figures 7.2 and 7.3). The headquarters of these four corporations are located within the respective settlements and land under the authority of the corporations is mainly situated in the corresponding parts of the municipality. However, dynamic allocations of ownership over the centuries have created a complex pattern. As an example, a large part of today's Freiteil forests is located in the former (historic) Kägiswil and Ramersberg districts. Additionally, several summering alps outside the municipality of Sarnen or even outside the canton are
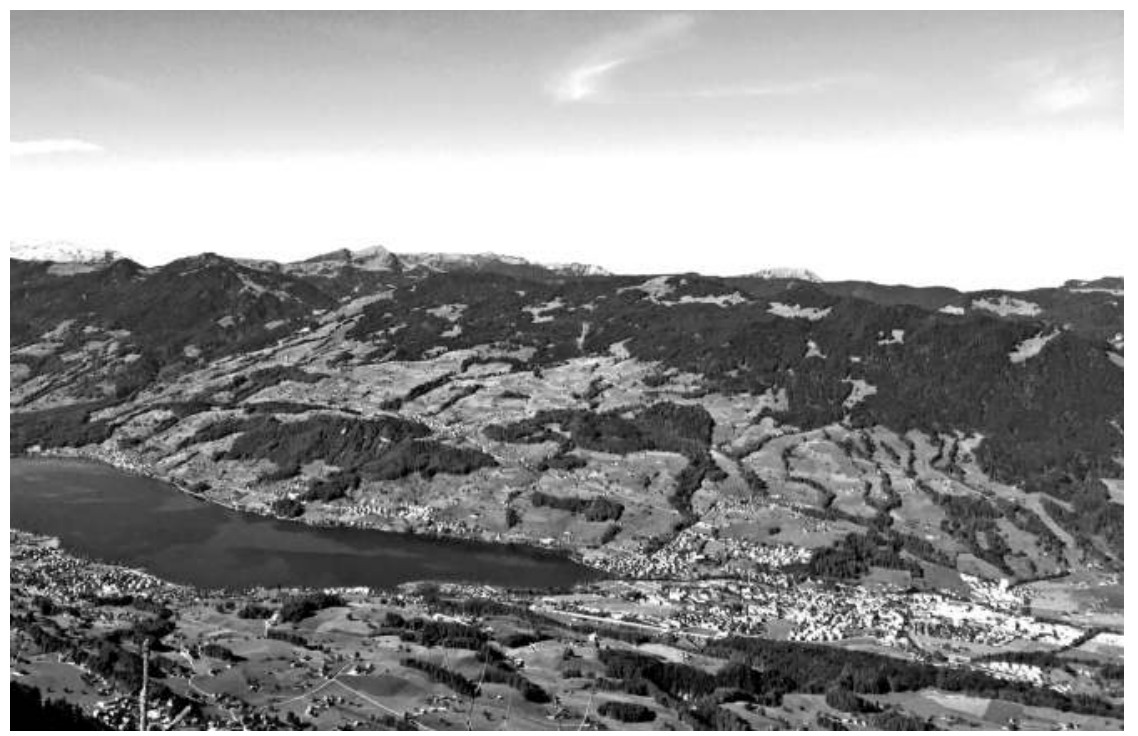

Figure 7.1 View of the study area with the main settlement area of Sarnen to the lower right and the Schwendi and Ramersberg corporation areas in the background. Source: Picture by Ariane Jedelhauser, 2016. 


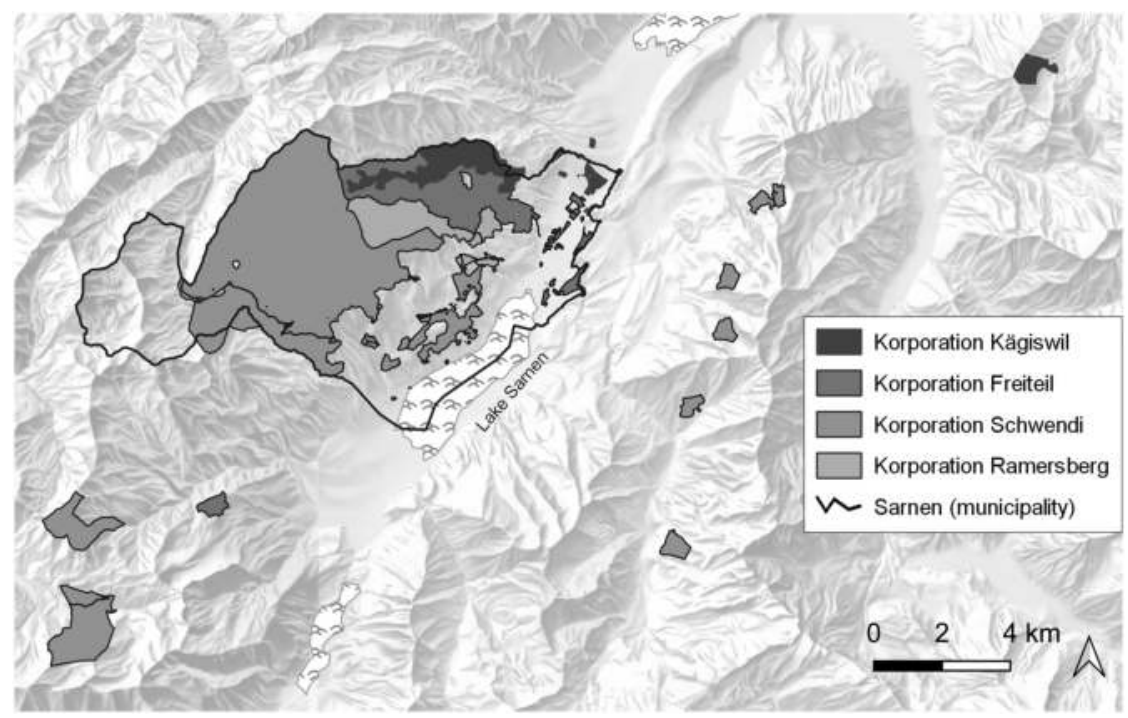

Figure 7.2 Landed property of the Sarnen corporations - overview. Source: Map compilation and design by Sarah Baumgartner, University of Bern. Geodata source: (C) GIS Daten AG Sarnen, 2020, www.gis-daten.ch; hillshade: Relief PK50, reproduced with permission of swisstopo (BA20043).



Figure 7.3 Landed property of the Sarnen corporations - land cover and use. Source: map compilation and design by Sarah Baumgartner, University of Bern. Geodata source: (C) GIS Daten AG Sarnen, 2020, www.gis-daten.ch; land cover data: swissTLM3D land cover, hillshade: Relief PK50, reproduced with permission of swisstopo (BA20043). 
owned by Sarnen corporations, above all by the Schwendi corporation, which owns fourteen alps in other municipalities (Figure 7.2).

\subsection{Institutional context and history of the Sarnen corporations}

In the region of the contemporary canton of Obwalden, the joint use of forests, alpine pastures and common agricultural land by Teilsamen (local historic term for a type of commoners' organisation) has been proved since the end of the fourteenth century. Nowadays, about $90 \%$ of the alpine pastures, $20 \%$ of the agricultural land (Norer \& Tschopp 2015) and 90\% of the forests (Lienert 2010) are under the authority of commoners' organisations, be they civic communities (Bürgergemeinden), corporations (Korporationen), alpine cooperatives (Alpgenossenschaften) or Teilsamen. In 2005, 92\% of livestock units were summered on common property pastures (Amt für Landwirtschaft und Umwelt 2005: 8). The current cantonal constitution ${ }^{3}$ states in Art. 107 (Legal status and duties): that the existing corporations, Teilsamen, and alpine cooperatives are acknowledged to be traditional public law bodies (öffentlich-rechtliche Körperschaften) for the management of their citizens' common property; that they shall be responsible for the management of their property, the disposition of whose yield is guaranteed; and that in the investment and management of assets, in particular in the event of disposal of land, economic development and strengthening of the community should be sought.

\section{Formation and development of the Sarnen corporations with changing significance of resources}

The Sarnen corporations stem back to at least the fourteenth century, the oldest written records comprising a judgement of the court of justice (15er Gericht) about land ownership of three of the corporations (Omlin 1913: 45ff.; Sigrist \& Älplergesellschaft Schwendi 1999: 8ff.). With the increased emergence and intensification of animal husbandry (among others connected to the growing market in the northern Italian region of Lombardy), the regulation of the use of alpine resources became more necessary and thus commoners' organisations experienced a noticeable increase in significance. Parallel to this process, a detachment from the manorial organisation of the alpine economy took place (Rogger 1989: 53). The major objective of the emerging corporations was to regulate the use of the common good (agricultural land, pastures, forests) ${ }^{4}$ and to promote the mutual benefit of the corporation citizens ${ }^{5}$ (Korporationsbürger). The constitution of the Schwanden Teilsame (today: Korporation Schwendi) of 1471 (Der Swandern Einung; Sigrist \& Älplergesellschaft Schwendi 1999: 17ff.) states that persons that settle in the premises of the corporation are allowed to use common agricultural land in the valley bottom (Allmenden), forests and pastures (Sigrist \& Älplergesellschaft Schwendi 1999: 18). It also regulates communal work (Gemeinwerk) as a function of livestock number, grazing fees 


\section{Karina Liechti}

and fines in the case of non-compliance with the regulations. A guiding principle is that summering rights are dependent on the livestock number that can be fed during wintertime (Garovi 2000: 132; Omlin 1913: 108, 112, 137).

Whereas at the beginning, new permanent residents were allowed full user rights (see above), with the increased interest in pasture farming and thus in alpine pastures and common agricultural land in the valley bottom (Allmenden), regulations for the defence against foreigners and for the safeguarding of common property were introduced in all Obwalden commoners' organisations (Rogger 1989: 239ff.). From the second half of the fifteenth century, such restrictions were extended to additionally include local inhabitants, so-called Beisassen and Hintersassen (Rogger 1989: 243). In the course of the centuries, most of the communities therefore experienced conflicts between commoners and people seeking to obtain rights to use common-pool resources (Omlin 1913; Rogger 1989; Garovi \& von Flüe 2018). In this process and in addition to the increasing economic importance of the resources, decreasing land availability, due to the growing population and in some cases the transition from common land to special ownership (e.g. through the construction of houses on common land) (Omlin 1913: 76), played an important role.

The focus on livestock farming as well as increased pressure on the land led to the purchase of summering pastures, including outside the region or even the canton (Abächerli, 1951: 12f; Omlin 1913: 137). It also contributed to forest clearing, at least until the seventeenth century (Sigrist \& Älplergesellschaft Schwendi 1999: 7; Lienert 1981b: 635). However, growing concern about the fast disappearance of forests led to their protection, with the first ban on forest use executed as early as the end of the fourteenth century and a peak being seen in the seventeenth century (Lienert 1981b: 635-636). Furthermore, strict regulations on forest use, among others a prohibition on selling wood beyond the corporations, were implemented (Lienert 1981b: 635). Another continuing conflict with regard to forest use centred on the issue of forest grazing (Waldweide) (Lienert 1981b: 638). Indeed, by the mid-eighteenth century, the first regulations on goat grazing were put in place, namely the complete prohibition of this practice in banned forests. In other forests, goat grazing was restricted to a defined number (Lienert 1981b: 638-639). Further areas of conflicts between the constituting corporations were related to land ownership claims because of unclear borders or with regard to land or forest that was used in common. For instance, the judgement of the court of justice (7er Gericht) of 3 June 1839 states that the citizens of the Freiteil corporation are to be guaranteed ownership and equal user rights - with the exception of the right to grazing - in the Kägiswil forest as Kägiswil corporation citizens (Omlin 1913: 10-11).

With the growing population and the development of Sarnen into a regional economic and political centre in the Early Modern Period, a diversification process between the four corporations started: whereas the Freiteil corporation citizens, who were located in the valley bottom in and around the growing regional centre of Sarnen, were increasingly also engaged in 
trade and commerce, the more "mountainous" corporations of Schwendi and Ramersberg, but also Kägiswil, continued to focus on animal husbandry involving alpine pasture use, eventually giving up crop cultivation (Omlin 1913: 49; Lienert 1981b: 633). Nevertheless, the constitutional laws (Einung) of the corporations did not significantly differ, containing regulations concerning citizenship and the responsibilities of the corporation organs. Additional to the constitutional laws, specific regulations for alpine pasture grazing, forest use and the use of common agricultural land were customary. Non-compliance with the regulations was a common issue for internal negotiation or conflict. As an example, the Schwendi corporation council in its session of 25 May 1856 summoned several people because of the following offences (Sigrist \& Älplergesellschaft Schwendi 1999: 118): unauthorised relocation of a goat to the summering pastures; unauthorised relocation of a sheep to the summering pastures; unauthorised grazing of a horse that was bought from outside the commune on the common grazing land; use of two user rights in one household; procurement of wood for construction and afterwards not using and protecting it against the weather; unauthorised wood cutting; unauthorised enlargement of a garden into the common agricultural land; dumping stones onto the common agricultural land; acorn collecting ahead of the authorised season; and sale of wood from the common forest without permission.

\section{The Sarnen corporations during the establishment and consolidation of the federal state}

Whereas the corporations lost their former functions with relation to education, religion and social welfare with the constitution and restructuring of the municipalities in the nineteenth and twentieth centuries, their role as custodians of common goods has remained persistent over the centuries all the way up to the present day. At the beginning of the twentieth century, Omlin (1913: 50) observed that the (then present) operational constitutions and regulations of the Sarnen corporations were already present - albeit at different stages of specification - in the fifteenth and sixteenth centuries. Nevertheless, developments and changes in society, above all the rising influence of public policies related to the establishment of the federal state from the mid-nineteenth century, forced the corporations to adapt, or rather to develop strategies concerning how to maintain or modify internal structures. The first National Forest Policy of $1876^{6}$ and the respective Cantonal Execution Ordinance of $1877^{7}$ defined all cantonal forests subject to state supervision, namely the state forests, the communal and corporation forests and the private protection forests (Art. 1). Consequently, the corporation regulations were also adapted (von Flüe 2012: 122). For instance, the forest regulations of the Schwendi corporation of $1879^{8}$ state (in accordance with national policies) that as a guiding principle for the preservation of the forest only as much wood can be cut as a sustainable yield allows (Art. 9). The common wood or forest regulations for the three corporations Freiteil, Kägiswil and Ramersberg of $1887^{\circ}$ refer to the same 


\section{Karina Liechti}

principle (Art. 11). However, even before the national and cantonal policies were taken up in the local regulations, corporations had regulated their forests according to similar principles. For example, the constitution of the Schwendi corporation of 1876 (Art. 18) ${ }^{10}$ states that

the young forest growth is to be favoured as far as possible, the growing forest is to be protected and the annual use is to be adapted to the forest stock as far as possible so that the descendants do not suffer damage and lack of wood. ${ }^{11}$

Regarding alpine pasture use, first national and cantonal policies such as the Federal Decree on the promotion of agriculture by the Confederation of $1884^{12}$ and the Cantonal Ordinance on the application of subsidies for soil improvement of $1897^{13}$ aimed to support the modernisation of alpine infrastructure and land improvements. For this reason, the Schweizerischer Alpwirtschaftlicher Verein (SAV; Swiss Association of Alpine Farming), which was founded in 1863, had carried out alp inspections in many regions from the 1880s (Viallon et al. 2019: 136). In the report on the inspection and awarding of prizes of the Obwalden alps, which was initiated by the Obwalden Farmers' Association and compiled in the period 1883 to 1890, the representatives of the SAV and the cantonal chief foresters who carried out the inspection suggested specific improvements for each alp. These concerned in particular the alpine buildings, fertilisation, water supply, paths, the clearing of shrubs and weeds and the "sore spot" posed by wooden fences, which represented a thorn in the inspectors' side due to the high levels of wood consumption. In addition, the unhindered grazing of large stretches of adjacent forest was considered "extensive farming, which no longer fits in with modern times" (Obwaldner Bauernverein 1890; Viallon et al. 2019: 136). Even though the SAV could not assert itself with some of its demands, the idea of infrastructure modernisation in particular was met with an open ear. The association had worked towards the federal government paying financial contributions to improvement projects of up to $40 \%$ of the costs since 1884. Such subsidies gave this idea a marked boost (Viallon et al. 2019: 139). The focus of the improvement works was on activities such as drainage and drainage systems, the construction and improvement of alpine paths and the construction of wells and new functional stables. In Obwalden, 80 alp improvement projects were realised between 1885 and 1912, with the largest part being invested in stable buildings (Schweizerisches Landwirtschaftsdepartement 1914: 4-5; Viallon et al. 2019: 149). Later, land improvement measures such as drainage (up to the 1970s) and the construction of access roads (up to the 1980s) gained in importance (Figures 7.4 and 7.5).

The new national and cantonal policies and land improvement projects stimulated adaptation processes, among others related to the establishment of clear borders between the corporations (from the beginning of the twentieth century until the 1930s), between forest and agricultural land (from the beginning of the twentieth century until the 1970s), or related to land-use 


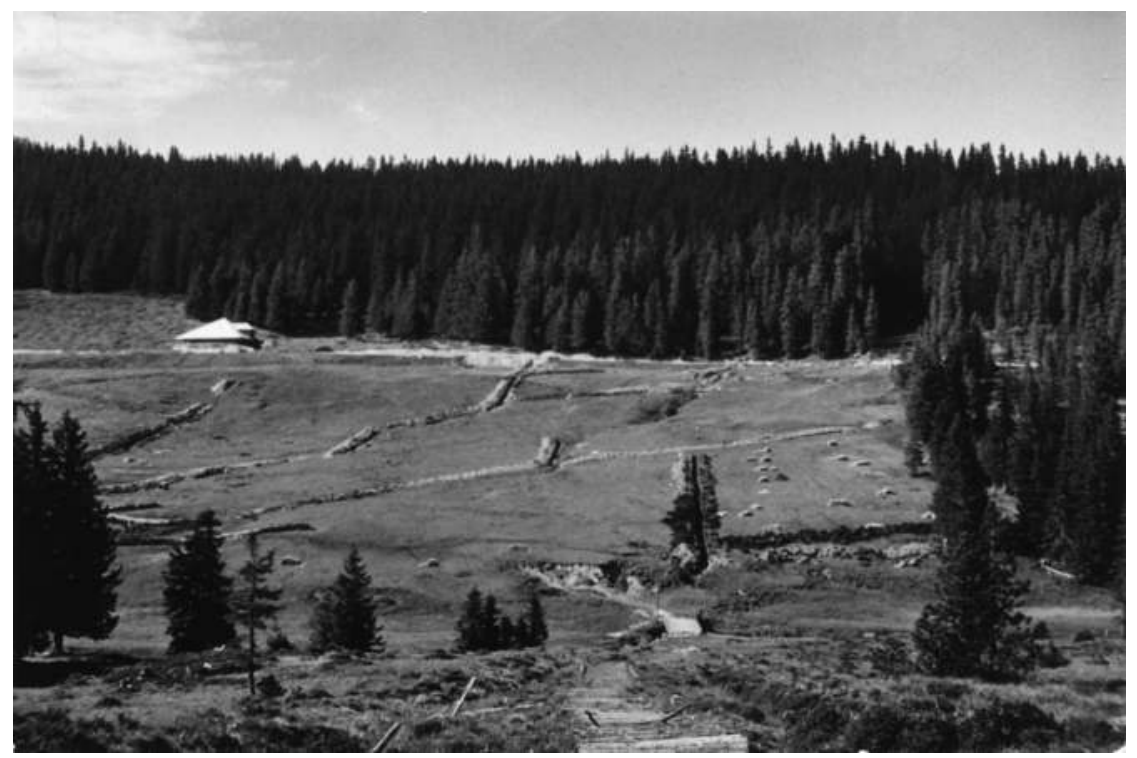

Figure 7.4 Skeleton drainage in connection with forest pasture separation, 1959. Source: Staatsarchiv Obwalden, E.0207:14.172 (05); photographer: unknown.



Figure 7.5 Forest path construction, 1938. Source: Staatsarchiv Obwalden, E.0207.04.030 (05); photographer: W. Steiner. 
regulations and organisation. In 1919, as an example, the owners of private alpine huts on the Ramersberg alp Käsern (location name) appealed against the decision of the Ramersberg corporation assembly to employ a herder to take care of all summered cattle. ${ }^{14}$ Previously, the owners of the private huts had the right to accept and herd cattle from other corporation citizens by themselves (this also being a reason why some of the huts were built). By this new measure of an employed herder, the corporation expected an improvement in alp maintenance, as the herder could be obliged to execute pasture maintenance and improvement work. The hut owners, however, considered this to be a pretext. They referred to the alpine statistics of the SAV (SAV/Etlin 1903: 64) that stated that the other Ramersberg alp "leaves much more to be desired in terms of improvement than the alp Käsern". In 1927, as another example, a farmer who owned an estate in Kägiswil appealed against the decision of the corporation assembly to allocate only half of the summering rights to areas newly made usable by land improvement measures in the valley bottom. ${ }^{15}$

Considering the self-determination and -regulation of the Sarnen corporations, however, it can be summarised that until the second half of the twentieth century, forestry was much more affected by national and cantonal regulations than agriculture and, in particular, the use of summering areas. In comparison to the forest, the state policy on pasture was primarily formulated as a subsidy policy rather than as a regulatory policy (Viallon et al. 2019: 142).

\subsection{Transformational change and diversified coping strategies of the Sarnen corporations in the last decades}

Major societal developments and changes with a large impact on the Sarnen corporations since the 1950s were structural changes in agriculture and forestry, including the decreasing proportion of the population working in the first sector, the diminishing profitability of agricultural and forestry products, the increasing importance of public policies in land management (e.g. related to agriculture, forestry, natural hazards, spatial planning, nature protection) and the growing proportion of public support for the provision of ecological and landscape services in forestry (above all contributions for protection forest) and agriculture (subsidies, direct payments). With regard to the practice of livestock summering, the increasing costs of managing the alps, the dwindling profitability of alpine products (dairy, meat) and the threat of abandonment triggered the federal government to start subsidising alpine grazing in $1980 .{ }^{16}$ From $1992,{ }^{17}$ the state redefined agrarian policy towards greater market integration and the establishment of a system of payments for ecological and landscape services, providing the farmers with an additional income. Such developments and changes were and still are important (external) factors that significantly changed the relative prizes of resources and contributed to the corporations' transformational change.

As a result of such societal developments and changes and the diverse characteristics of the four corporations (as will be further explained below), 
transformational change within the corporations has taken different forms in the last few decades. These changes can be differentiated into the dimensions of organisation, institutions, bargaining power and ideology (see Ensminger 1992) and will be discussed in the coming sections. As coping strategies are inherent in these dimensions, organisation, institutions, bargaining power and ideology cannot be understood in isolation from each other, but rather as resulting from continuous interaction. Adaptive and proactive coping strategies that are of a more overarching nature, especially including common strategies of all corporations, will be discussed in a separate section.

\section{Organisation}

Common characteristics of all Sarnen corporations include the fact that they are constituted of citizen lineages, who have been resident in the region for centuries (Garovi et al. 2012). Latecomers were more or less excluded from attaining full citizenship and/or were (and still are) provided with limited user rights. The last major incorporation of new citizens was enforced in 1853 as a result of the national act on the abolition of homelessness ${ }^{18}$ (Heimatlosigkeit) and the naturalisation (Einbürgerung) of "tolerated people" in Obwalden (Sigrist \& Älplergesellschaft Schwendi 1999: 29). Whereas the constitutional rights do not differ substantially, the Sarnen corporations can today be characterised by structural diversity. They mainly differ in terms of the amount of land holdings in the corporations' authority (with the Schwendi corporation being by far the largest landholder), the share of corporation citizens in total population, the proportion of farmers among the citizens and the income structure. Broadly speaking, the corporations can be differentiated between: the Freiteil corporation being a rather urban commoner situated in the town of Sarnen with a contemporary economic focus on real estate; and the Kägiswil, Schwendi and Ramersberg corporations as more rural commoners in different degrees of diversification, with Ramersberg being the corporation that has largely maintained its "traditional" function and the largest proportion of corporation citizens within its total population (Table 7.1).

A considerable share of changes leading to the current level of diversity, above all with respect to economic and social aspects, has evolved over the last decades. Whereas especially forestry up until the second half of the twentieth century was a secure income base for all corporations, structural changes in agriculture and forestry, namely the decreasing profitability of agricultural and forestry products, rising workforce costs and the modernisation of infrastructure, brought about major (financial) challenges. Furthermore, the composition of the corporations' citizens, with a decreasing number of people working in the first sector (Table 7.1), the expanding number of public policies and the growing level of dependency on governmental support (e.g. for protection forest management or for livestock summering) has changed and extended corporation structures and networks. In view of financial challenges, the corporations have thus diversified to a greater or lesser extent since the second half 


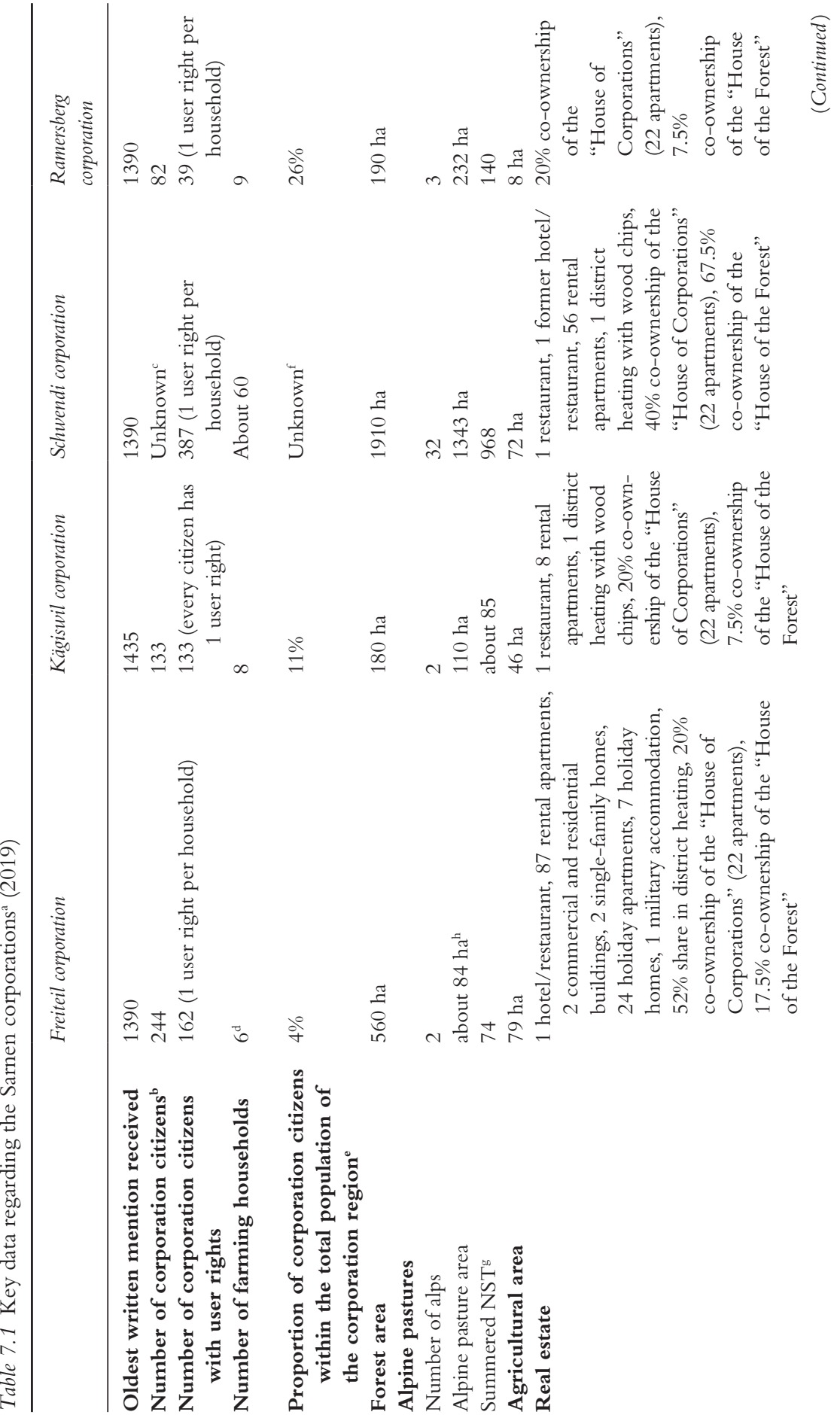







of the twentieth century. As a result, today in the Freiteil corporation about two thirds of the income is generated in real estate (rental income and land leases with building rights); in the Schwendi and Kägiswil corporations, too, real estate accounts for an important income share. ${ }^{19}$ The increased focus on real estate has primarily resulted from the perceived need to generate a secure economic foothold in the face of declining yields from common forests, agricultural land and alpine pastures, as indicated in the following statement by a Freiteil corporation representative:

In the post-war period, the yields from forestry and agriculture continuously decreased. Before, you earned money from forestry and agriculture. And with that money, you could cover your costs or at best buy something that was due. This was no longer possible. The deficits became bigger and bigger and you always had to cut off a slice of the land and sell it in order to cover the deficits. With the new strategy that we take now, to lease land with building rights, we earn a profit for a long time. This is actually like another form of development or land management: the ownership remains in the corporation in the long term and every year a profit is generated that can be used for new projects. $^{20}$

This statement is echoed by another representative from the Kägiswil corporation stressing the idea of long-term sustainable financial investment: "Our corporation bought the first flats about 15 years ago. At that time it was a bit of an investment. They always talked about investing capital. [...] This has been well received by the corporation citizens". ${ }^{21}$ The important issue here is that the investment was not driven by a speculative nature but by a strategy to generate surpluses in these new fields of income, which can be reinvested in sectors that are not cost-covering, such as agricultural land and infrastructure. This is also reflected in the constitutions of the respective corporations; for example, the Freiteil constitution of $2009^{22}$ states that corporation assets (Vermögen) must not be reduced and revenues, in particular from land sales, must be reinvested (Art. 21). However, such processes have also engendered considerable conflict among citizens, including between people in favour of selling land and land tenants. One corporation representative described such conflictual situations as follows:

Yes, most of the time, when a conflict exploded [...], it was about something that certain people didn't agree to spend money on. Or that we sell building land. In their opinion, we should have kept the land so that they could continue to graze on it. As long as you can graze, you can milk. ${ }^{23}$

In comparison to the other corporations, Ramersberg has barely changed its structure in the past decades. Its main income is still generated from the forests 
and the alpine pastures (Table 7.1), which is seen as a challenge, as the following statement makes clear:

We have no apartment block, we have no restaurant, we have no hotel, we also have no land to sell, we have no building land. So actually, we do not have anything to generate money with. So we always have to see how we can turn around in this zero-sum game. That's the challenge. ${ }^{24}$

The reasons why Ramersberg did not pursue the same strategy as the other corporations are related to factors such as location, size and identity. The Ramersberg corporation mainly struggles when unexpected expenses such as damages as a result of natural hazards (e.g. the destruction of access roads) arise or when the modernisation of infrastructure (e.g. for cheese making) is due.

Apart from housing, the most popular way of generating some additional income in three of the corporations (except Ramersberg) today is the operation of district heating systems, which are operated with local wood. Despite the support of governmental subsidies, they are not very profitable, but they are seen as progressive solutions for the use of local resources. As a representative of the Kägiswil corporation stated:

Woodchip district heating is a very good thing for us. We were able to do this at the time because the federal government made a "climate cent" [Klimarappen] programme. We thus pioneered ecological heating in the village. The corporation did it because they can recycle waste wood to produce wood chips. [...]. The branches, the small stuff, you can either let it rot in the forest outside or chop it up. This was the first time that the not really profitable wood was put to good use. ${ }^{25}$

Along with the diversification of income sources and the rising workload also due to growing bureaucracy - the corporations have professionalised their administration (Table 7.1). This process, among others, has obviously also contributed to the distribution of power and reduced arbitrariness in decision making:

Almost every corporation today has an administrator who manages. And they look at things a bit detached from power. In the past, the corporation secretary was the administrator. He wrote everything. And the president ran from $A$ to $Z$ [was responsible for all the rest]. Nowadays, they separate the strategic from the operational side. And that's a bit a more like modern management. ${ }^{26}$

Only the administration of the Ramersberg corporation is still traditionally done by the corporation council within the scope of the council's activities and compensation. However, it was mentioned - additionally from the view from the outside - that compared with a municipality, whose procedures are highly 
standardised, continuity is less guaranteed in the corporations, as their strategic focus is highly contingent on the council's composition.

Despite these major changes in income structure, in terms of area relevance and presentation to the outside world, the Sarnen corporations (with the exception of Freiteil, where in the last few centuries trade and commerce also played an important role among citizens) have largely preserved an agricultural-forestry habitus. This is visible in external communication (websites, annual reports, reports in the media), but above all in the cultural traditions, the regulations, the narratives about the corporations' objectives and identities (see sections "Institutions" and "Ideology") and the citizens addressed.

\section{Institutions}

The corporations' constitutional laws (Einung) are designed to preserve their stocks and existence (Bestandeswahrung) and contain the regulations concerning the responsibilities of the corporation organs (council, assembly, etc.) and citizenship. As mentioned before, regulations related to corporation citizenship have not changed a lot over the centuries: citizenship was and is still linked to lineage ("A corporation citizen becomes [...]: a) who is descended from a corporation citizen up to and including the second generation. [...] b) the spouse of a corporation citizen; $[\ldots]^{\prime 27}$ ) and residence, which means that residence in the corporation territory is a prerequisite. Only in the course of consolidating gender equality in the Swiss Constitution in 1981 did constitutional laws need to be adapted in such a way that both men and women could keep and transfer their citizenship after marrying a non-citizen (Garovi et al. 2012: 245ff.). A further extension of citizenship rights is currently not foreseen in any of the four corporations. The communicated reasons behind this are that a closed and small group of citizens is seen as advantageous with regard to the maintenance of a common identity as well as fast reactivity. Potential threats of expanding citizenship are perceived in the potential reproach of arbitrariness if only selected persons were accepted, or the decreasing ability to steer the corporations in a certain direction. ${ }^{28}$

Corporations are generally constituted by the corporation assembly of citizens (Korporationsversammlung; Figure 7.6), which elects the corporation council (Korporationsrat) and, depending on the corporation structure, by diverse administrators (e.g. Alpverwalter) and commissions, whose members are nominated by the council. The officials receive compensation for their work, although due to the abundance of duties, it is "customary" that a part of the work is completed free of charge. The issue of finding successors for the diverse functions was perceived as a challenge by the corporation representatives, but not to the extent that would cause substantial problems up to now. However, far-sighted planning was considered as essential. Limitations on terms of office exist in some but not all of the corporations.

User rights for the use of common agricultural land and summer pastures are linked to corporation citizenship and agricultural practice (Table 7.2). Wood, 


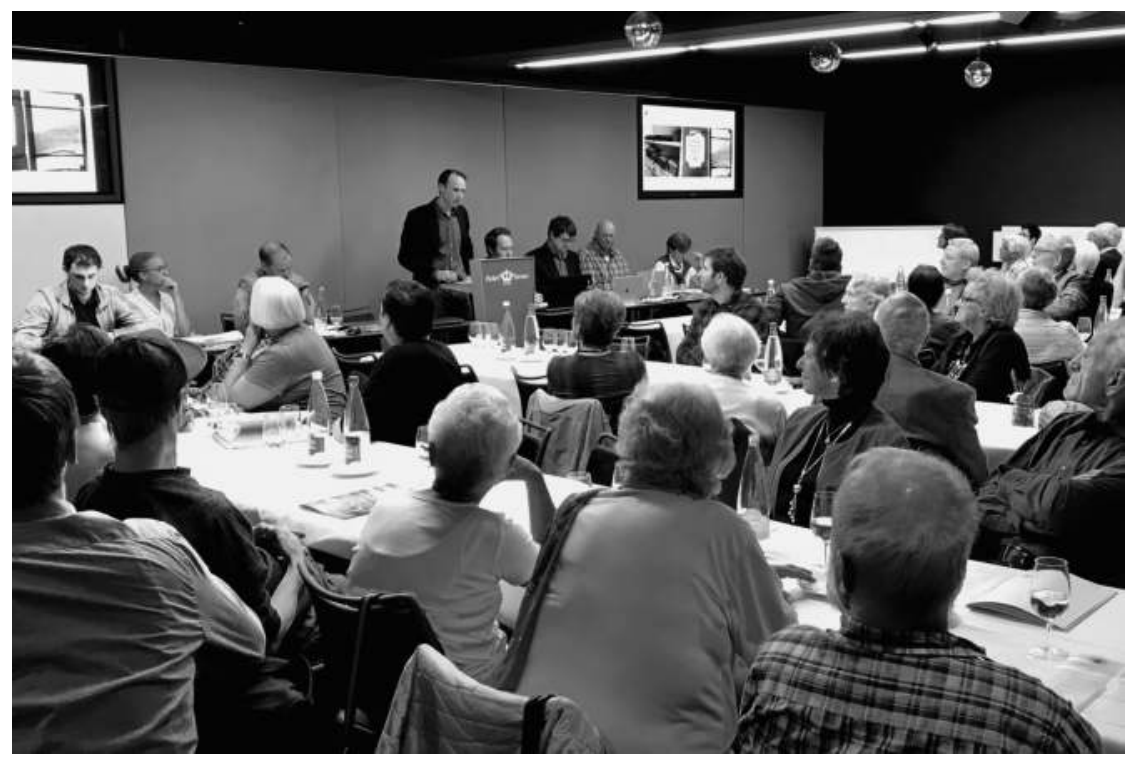

Figure 7.6 Corporation assembly of citizens. Source: Picture by Karina Liechti, 2018.

which was formerly granted to all corporation citizens, is nowadays no longer in great demand and is typically only granted when requested. As a form of compensation, citizens with user rights today receive an annual "distributional allowance" (Austeilgeld), the amount of which is contingent on the corporations' financial potential (Table 7.1). The Freiteil constitutions of $1976^{29}$ and $2009,^{30}$ as an example, illustrate the change from natural resource-based to monetary-based benefits that are given to the citizens. By 1976, different forms of compensation already coexisted:

All Freiteil citizens who meet the conditions as authorised users [...] are entitled to the Freiteil benefit [Freiteilnutzen]. This consists of: a) [...] a part of the common land, where still available, [...], or a monetary compensation; b) a distributional allowance [...]; c) firewood, according to the forest regulations. The cash compensation for non-beneficiaries of firewood is determined by the council.

(Art. 24)

In the Freiteil constitution of 2009 it can be seen that the changes go even further, but are formulated more cautiously:

All Freiteil citizens who meet the conditions as authorised users [...] and if financial circumstances permit, are entitled to the Freiteil benefit 
Table 7.2 Consistency and adaptation of alpine pasture use regulations using the example of the Schwendi corporation

\begin{tabular}{|c|c|c|c|}
\hline & Regulation $1948^{a}$ & $\begin{array}{l}\text { Changes (Regulation } \\
2017^{b} \text { ) }\end{array}$ & Drivers \\
\hline User rights & $\begin{array}{l}\text { User rights only } \\
\text { for corporation } \\
\text { citizens; alpine } \\
\text { summering only } \\
\text { for livestock that } \\
\text { has been fed } \\
\text { in winter with } \\
\text { fodder grown in } \\
\text { the corporation } \\
\text { area. }\end{array}$ & $\begin{array}{l}\text { In the case of } \\
\text { understocking } \\
\text { with corporation } \\
\text { livestock, external } \\
\text { livestock can be } \\
\text { summered. Also, } \\
\text { the requirements } \\
\text { regarding local } \\
\text { fodder have been } \\
\text { lowered. }\end{array}$ & $\begin{array}{l}\text { Agricultural structural } \\
\text { change and } \\
\text { rising mobility: } \\
\text { decreasing interest } \\
\text { in summering; } \\
\text { summering options } \\
\text { in other regions; } \\
\text { possibility to } \\
\text { purchase fodder. }\end{array}$ \\
\hline $\begin{array}{c}\text { Communal } \\
\text { work }\end{array}$ & $\begin{array}{l}\text { Five hours of } \\
\text { communal work } \\
\text { per livestock unit } \\
\text { summered (see } \\
\text { Figure 7.7). }\end{array}$ & No change. & - \\
\hline Stocking rate & $\begin{array}{l}\text { Determined by the } \\
\text { corporation. }\end{array}$ & $\begin{array}{l}\text { Determined by the } \\
\text { cantonal office } \\
\text { (partly based on } \\
\text { customary rates). }\end{array}$ & $\begin{array}{l}\text { Direct payments per } \\
\text { livestock unit; } \\
\text { sustainability } \\
\text { considerations; new } \\
\text { protection status } \\
\text { (mires). }\end{array}$ \\
\hline $\begin{array}{l}\text { Type of animals } \\
\text { allowed }\end{array}$ & $\begin{array}{l}\text { Only milking cows } \\
\text { are allowed for } \\
\text { summering. } \\
\text { Certain } \\
\text { exceptions for } \\
\text { sheep and goats. }\end{array}$ & $\begin{array}{l}\text { Suckler cows are } \\
\text { also allowed. } \\
\text { The corporation } \\
\text { council assigns the } \\
\text { alps that can be } \\
\text { used by suckler } \\
\text { cows. }\end{array}$ & $\begin{array}{l}\text { Diversification } \\
\text { of agriculture, } \\
\text { decreasing interest in } \\
\text { summering. }\end{array}$ \\
\hline Alp allocation & $\begin{array}{l}\text { Random allocation } \\
\text { of alps by lot } \\
\text { (Alpverlosung) } \\
\text { every four } \\
\text { years among } \\
\text { consolidated } \\
\text { pasture } \\
\text { user groups } \\
\text { (Bauernsamen) that } \\
\text { have articulated } \\
\text { their interest in } \\
\text { summering cows. }\end{array}$ & $\begin{array}{l}\text { The alps are allocated } \\
\text { by lot for eight } \\
\text { years. However, } \\
\text { the draw will } \\
\text { only take place } \\
\text { if at least three } \\
\text { pasture user groups } \\
\text { (Bauernsamen })^{\mathrm{d}} \\
\text { submit a request } \\
\text { to the corporation } \\
\text { administration. }\end{array}$ & $\begin{array}{l}\text { User request and } \\
\text { recommendation } \\
\text { of the cantonal } \\
\text { authorities due to } \\
\text { pasture quality and } \\
\text { planning security } \\
\text { reasons. }\end{array}$ \\
\hline
\end{tabular}


Table 7.2 (Continued)

\begin{tabular}{|c|c|c|c|}
\hline & Regulation $1948^{\mathrm{a}}$ & $\begin{array}{l}\text { Changes (Regulation } \\
2017^{\mathrm{b}} \text { ) }\end{array}$ & Drivers \\
\hline $\begin{array}{l}\text { Alp } \\
\quad \text { improvement }\end{array}$ & $\begin{array}{l}\text { Collect litter, } \\
\text { distribute manure, } \\
\text { build fences and } \\
\text { provide fence } \\
\text { material for the } \\
\text { following year, } \\
\text { maintain water } \\
\text { troughs, eradicate } \\
\text { weeds, fence in } \\
\text { hay meadows, } \\
\text { clear pasture } \\
\text { paths, pay for } \\
\text { and sow artificial } \\
\text { fertilisers. }\end{array}$ & $\begin{array}{l}\text { Spread manure, } \\
\text { eradicate weeds, } \\
\text { build and maintain } \\
\text { fences, provide } \\
\text { fence material for } \\
\text { the following year, } \\
\text { prepare firewood, } \\
\text { maintain water } \\
\text { troughs, fence hay } \\
\text { and litter meadows, } \\
\text { use fertiliser where } \\
\text { permitted. }\end{array}$ & $\begin{array}{l}\text { According to the } \\
\text { written regulations } \\
\text { no major changes. } \\
\text { However, one } \\
\text { must comply with } \\
\text { national and cantonal } \\
\text { regulations (e.g. } \\
\text { fencing of mires, no } \\
\text { drainage of mires, } \\
\text { restricted use of } \\
\text { fertilisers). }\end{array}$ \\
\hline Sanctions & $\begin{array}{l}\text { Violations are } \\
\text { punishable by the } \\
\text { corporation penal } \\
\text { authority with } \\
\text { a fine of up to } \\
80 \text { Swiss francs. } \\
\text { Higher penalties } \\
\text { are referred to the } \\
\text { cantonal criminal } \\
\text { judge. }\end{array}$ & $\begin{array}{l}\text { In case of violations, } \\
\text { the penal } \\
\text { provisions of the } \\
\text { confederation and } \\
\text { the canton apply. If } \\
\text { they do not apply, } \\
\text { infringements shall } \\
\text { be punished by a } \\
\text { fine. }\end{array}$ & $\begin{array}{l}\text { Increasing governmental } \\
\text { regulations (e.g. } \\
\text { regarding animal } \\
\text { welfare, hygiene, or } \\
\text { nature protection); } \\
\text { obligation to comply } \\
\text { with cantonal and } \\
\text { national legislation. }\end{array}$ \\
\hline
\end{tabular}

${ }^{a}$ Verordnung über die Bewirtschaftung und Benutzung der Alpen der Teilsame Schwändi 1948.

b Alpenverordnung Schwendi 2017.

c Only cows that according to the animal tracing database have been wintered in the corporation and with hay mainly grown in the same may be summered. The maximum number of cows allowed per holding is 20 (based on Art. 4, Abs. 1).

d Out of a total of 16 (2017).

[Freiteilnutzen]. This consists of: a) a cash compensation to replace the rent for the former parts of the common land; b) firewood or a cash compensation as firewood equivalent.

People who live in the corporation territory but are not corporation citizens, the Beisassen, can apply for the use of corporation resources. Depending on the regulations, they can attain certain restricted user rights, for example, the use of summer pastures in understocking situations, in predefined areas, with a limited number of cattle, or to a higher fee. ${ }^{31}$ Nowadays, with the decreasing pressure on the summer pastures, cattle of Beisassen are generally accepted. 
In comparison to corporation citizenship regulations and rights, regulations related to forest and pasture use show more significant changes. Whereas forest use regulations were closely linked to the National Forest Policy of $1876^{32}$ already in the late nineteenth century, governmental impact in alpine pasture regulations only started in the 1980 s, related to the establishment of a subsidy system with direct payments for cultivators (farmers and partly corporations) in order to support and maintain alpine pasture use. This impact mainly concerns the stocking rate (the maximum and minimum sustainable yield for each alp according to the productivity of its pastures) and the type of management (e.g. rules regarding the protection of pastures against shrub and forest invasion, fertilisation practices, protection of biodiversity, weed control, hygiene standards for cheese production). As similar rules had to a certain extent (not covering biodiversity, for example) already been formalised and made operational in the corporation regulations before that (for example related to communal work; Figure 7.7), governmental impact on formal pasture use regulations was rather low in comparison to changes resulting from general societal changes (e.g. agricultural structural change and the growing importance of nature protection; see the next section). The consistency and the adaptation of alpine pasture use regulations are described in greater detail in Table 7.2 using the example of the Schwendi corporation. As an example, a regulation that has changed in recent years is the random allocation of alps by lot (Alpverlosung) every four to eight years. This regulation was intended



Figure 7.7 Communal work (Gemeinwerk) of corporation citizens. Source: Picture by Walter Abächerli, 2019. 
to guarantee a certain equity between pasture user groups, as summer pastures differ in quality. However, due to internal and external drivers, this regulation has been adapted to be applied more flexibly and with a more long-term orientation and is thus now closer to diverse actors' needs (Table 7.2). An Obwalden cantonal representative described the reasons behind this adaptation process as follows:

It is certainly successful if an alp is managed by the same people for a longer period of time. In this case, the users invest in alp improvement. Before, with the allocation of alps by lot and the resulting alp changes every several years, they did some maintenance work at the beginning and after that, when it came towards the end of the turn, they left the young fir trees and the weeds on the pastures and the next user had to clean up again. [...]. Furthermore, if you have a farm in the valley, with all the investments, there must also be a certainty that the land on the alp is secured in the long run. This is why we have been working to ensure longer term user rights in the summering areas. ${ }^{33}$

Further institutional changes are linked to the tendency of some of the corporations to no longer manage their alpine pastures by themselves, but rather to lease out individual summering alps and thus hand over a part of the responsibilities (e.g. hiring a herder) to alpine pasture user groups from among the citizens (Bauernsamen) or to individual farmers. Nevertheless, the issuance and changing of regulations in such cases remain the duty of the corporation council. These kinds of shifts in responsibilities are not new; they also have been observed over the past decades in connection with the use of common agricultural land in the valley bottom, as indicated in the following statement by a Freiteil corporation representative:

In the past, the corporation citizens drove the cattle to the common lands and in the evening, they took it home and milked it. That changed here very early. Many citizens did not live from agriculture any more, they no longer had their own cattle. [...]. The same happened with the common gardens: in the past, everyone had their garden there. This started to decrease very early. Consequently, we leased the common lands to farmers and compensated the others. ${ }^{34}$

According to the corporation representative from the most traditional corporation (Ramersberg), where all three alpine pastures were managed directly by the corporation up to 2018 but since 2019 two have been leased out, such a handover of responsibilities already constitutes a first step away from the community mindset: "Most corporations have leased out parts of their land. This is actually a bit like saying goodbye to this cooperative idea." 35 


\section{Bargaining power}

\section{Spatial and proportional relevance}

According to the cantonal constitution, the corporations are guaranteed the management of their property and the disposal of its yield ${ }^{36}$ (Art. 107, paragraph 2) as long as their activities comply with the cantonal and federal legislations. The right to control about $56 \%$ of the municipal territory thus makes corporations important stakeholders in dealing with important societal issues such as spatial planning, natural hazard protection, landscape development, nature protection and leisure. In comparison to the large land holdings, only a small proportion (about $8-10 \%$ ) of the total Sarnen population are corporation citizens today. ${ }^{37}$ When one considers that in $1850,73 \%$ of the Sarnen population were corporation citizens (Garovi et al. 2012: 250), this represents a significant decrease. The reasons for this development are the interlinkage between general population growth due to in-migration and restrictive incorporation regulations. The growing discrepancy between number of citizens and spatial relevance has in the past stirred up occasional criticism among non-citizens and authorities, asserting that corporations have too much power or that corporation citizens are being privileged over "ordinary people". With regard to the Freiteil corporation, one corporation representative described the situation as follows:

The Freiteil corporation [for a certain time] did not necessarily have the best image among non-citizens. [...]. One always looked at them a bit like big landowners: all the large common areas, the building plots ... If you look at where the apartment blocks of flats are, it was largely Freiteil land. They have always sold building land and have become richer and richer. And therefore, in my opinion, the normal resident has not developed an overwhelming sympathy for them. ${ }^{38}$

Additionally, as non-citizens and "newcomers" are scarcely coming into contact with corporation issues, corporations and their functioning and services are said to be losing public awareness, above all in the more urban areas. Referring again to the "urban" Freiteil corporation, one Sarnen municipal representative claimed:

I would say, for the general townspeople who live here, who do not live in a corporation apartment and are not a corporation citizen, the corporations have a subordinate meaning. If you go into the street and ask someone what his relation with the corporations is, or what a corporation is at all, you would not get any clever answers. The society has changed, from the agricultural focus into another direction. Some people still know that there are corporations, but I do not think that they [the corporations] are particularly in the collective memory. ${ }^{39}$

In the more rural areas, where people are more directly connected to agriculture or agricultural landscapes, the work of the corporations is - in the 
view of the respondents - still more likely to be noticed and appreciated. In these regions, the understanding of a corporation as mainly dealing with agricultural issues and favouring farmers over other citizens or non-citizens remains an issue.

The decreasing public recognition of corporations - and thus the threat of losing bargaining power - became apparent in the course of the dissolution of the civic community ${ }^{40}$ (Bürgergemeinde) of Sarnen in 2010. By this time, this traditional collective entity had lost almost all of its responsibilities, with the exception of naturalisations (Einbürgerungen). During the dissolution process, conflicting views with regard to the distribution of the civic community's properties arose between the municipality and the corporations, which sometimes even led to the continued existence of the corporations being questioned by some involved actors. ${ }^{41}$ This encouraged the corporations to join forces in order to become more visible and to fight for their rights in common. A former corporation president described the process like this:

When the civic community was dissolved, it became clear that even many municipal council members no longer had a clue what the purpose of a corporation was. They wanted to integrate the civic community assets into the municipal assets. And we corporations then reacted and resisted together. We said that the civic community actually came into being out of the corporations. So the civic property must not simply be transferred to the municipality, but a part of it must go back to the predecessors of the civic community, the corporations. And because there were four of us, we had weight with the municipality and were then able to really divide up the civic community's assets. ${ }^{42}$

This process also encouraged the corporations to communicate their functions in society more actively (see below), which, in the view of one corporation representative, helped improve their image. With regard to the Freiteil corporation, he expressed his hope as follows:

In this way, the many Sarnen women and men who are not Freiteil citizens should notice: "Yes, these Freiteil citizens aren't self-centred capitalists; they do something for society. They work like small corporations for the benefit of the entire population. Housing is for the benefit of the whole population and not for the interest of accumulating capital". ${ }^{43}$

\section{Interactions with higher state levels}

With regard to bargaining power in interactions with higher state levels, research has given rise to the conclusion that at the beginning of new state or cantonal regulation implementations (e.g. when new national policies, such as in the context of environmental protection and conservation, were being implemented), corporations were frequently consulted but not involved 
in decision-making. This can be exemplified in the context of state efforts to improve nature protection, above all with the procedures after the federal vote on the so-called Moorschutzinitiative (Mire Protection Initiative) in 1987. For the Sarnen corporations, the adoption of the Mire Protection Initiative - an initiative of Swiss civil society organisations, which had been democratically voted on and accepted nationally - implied a long process of negotiation and adaptation to the new framework conditions. According to Bisang et al. (2008: 51), who have analysed the implementation of mire protection in the canton of Obwalden, the first phase took place exclusively within the administration: the various offices drew up plans for the individual biotopes with the respective protection provisions. This lack of involvement met with resistance from landowners (farmers, corporations, municipalities), who said that people from Sarnen or Bern had collected data on their land for days or weeks without informing them (Bisang et al. 2008: 51). Bisang et al. (2008: 51) have concluded that land ownership was not respected and there was a lack of understanding and respect for traditional agricultural knowledge. The general dissatisfaction with the approach led to a political initiative (Motion $\mathrm{Odermatt}^{44}$ ), as a result of which the implementation was restructured (Bisang et al. 2008: 52f). Consequently, the owners were invited to orientations and inspections and the exact protective perimeters and conditions were determined in joint inspections (Bisang et al. 2008: 53). In the process, different knowledge systems - natural science and local knowledge - met, came into conflict and needed to be negotiated. As an example, in the view of local users, the natural scientists (among others) lacked knowledge on the mobility patterns of herding animals and their associated impact on the cultural landscape. As one former corporation forester explained:

We went through the pastures together. But they [biology experts] had no idea how the cattle move. Cattle move back and forth [...], they never go straight up or straight down. They had a lot of knowledge about flowers, but not about cattle. A fence must never have a sharp angle. The [cattle will be trapped in this angle and the] fence will simply break down and then the cattle will be everywhere again [...]. So we had to discuss things like that. [...] That's how we made compromises. ${ }^{45}$

Alternatively, seen from the point of view of a cantonal representative:

Subsequently, these land-use plans were drawn up in the 1990s. This was also done together with the corporations. It was important for them to be informed. Communication hadn't worked so well before: at some point the inventories were there and nobody knew why and how. And afterwards we had to implement the stuff, together with the corporations. And the farmers' interest was of course to keep the pastures, to put the animals up. On the other hand, there was money earmarked for the corporations, contributions [e.g. for fencing] and so on. ${ }^{46}$ 
Today, the corporation representatives more or less accept the fact that the mires need to be protected. However, the restrictions, the low flexibility in the implementation of projects and the control from outside continue to be criticised, as can be seen in the following statement: "Generally, we are already getting used to it, there is nothing one can do, isn't there? It is however something that comes up again and again: the restrictions you have because of mire protection, nature conservation". ${ }^{47}$

According to Bisang et al. (2008: 54), the acceptance of mire protection was favoured by parallel developments in Swiss agricultural policy. The structural change in Swiss agriculture resulted in there being less livestock available for summering and thus a reduced pressure to use the land (Bisang et al. 2008: 54). Furthermore, the promotion of extensification of land use through compensation payments enabled farmers to comply (among other things) with protection regulations without suffering financial losses (Bisang et al. 2008: 54). In addition, the fact that a certain land use was considered as a valuable protection measure for selected parts of the mire landscapes and was compensated, contributed to their acceptance. For example, farmers today receive a contribution for mowing plant litter (Streue), as this supports the preservation of mire landscapes, or for fencing, as it keeps animals away from the strictly protected raised bogs. In any case, governmental subsidies were and are bound to conditions that are largely unnegotiable and force the corporations to adapt their activities, which partly means "obeying". This is also valid for forestry issues, as the following statement exemplifies:

The forestry industry was increasingly unprofitable and there were subsidies for many things. And when you wanted something, the others [the cantonal officers] said "Yes, but there has to be a fence" [between the forest and the pasture]. You always had to obey [...]. If, for example, access roads were built for forestry, it was of course always a condition that the livestock was regulated in this catchment area. Otherwise, you wouldn't get any contributions from the public. It was a bit of a constraint. ${ }^{48}$

Nevertheless, the low extent of changes in the corporations' proper constitutions and regulations - apart from adaptations of stocking rates - show that higher state levels on the one hand recognised the right to self-management and/or considered the existing systems suitable for their purposes. On the other hand, it is a reference to the bargaining power the corporations had at a specific moment. The respondents indicated that cooperation between the cantonal authorities and the corporations have been intensified and improved in recent years, among other reasons because the canton administrators realised that they cannot override the opinions of the corporation representatives as this would result in a low level of compliance. Such mutual dependency was articulated by one corporation representative as follows:

I would say that we are fundamentally dependent on each other. Probably we rely a little more on them [the responsible persons of the canton] than 


\section{Karina Liechti}

they do on us. And that's why we shouldn't complain too much, [we] just have to see to it that things work out. ${ }^{49}$

Furthermore, due to the small-scale nature of the local context, the different representatives know each other quite well, which promotes negotiations. This is illustrated in the following statement with regard to new regulations for designated wildlife areas (Wildruhezonen):

We always get a consultation, we are always involved and we all know them, don't we? The head forester knows us all and he gives us a phone call before the official consultation, shows us his ideas, what they have in mind. Before the official consultation, we can already express our opinion. ${ }^{50}$

Nevertheless, corporations are on the lower bargaining power end, as they rely on good informal and personalised contacts, which are also person-dependent.

Regarding the implementation of corporation-led projects (e.g. concerning drainage, renovations or new infrastructure), demanding but relatively good cooperation with other actors involved, above all the authorities, was said to have developed in the meantime:

In connection with A. [name of a location], we had to make an access road through the mire. There we were really dependent on the people from the cantonal office and we involved them from the beginning. So, we could find an adequate solution together. ${ }^{51}$

However, other voices, for example from nature protection NGOs, viewed cooperation much more critically:

Since a large part of the alps is owned by corporations, it is logical that we have to deal with them, for instance in certain construction projects such as new access roads. After all, we want to enforce compensatory measures: that if they take something away from nature, they must also do something for nature again. Or that paths do not pass through valuable areas or are not built as wide as possible. And sometimes, this does not really meet with the understanding of the corporations. ${ }^{52}$

In such negotiations, the clash between economic efficiency and nature conservation becomes apparent, for example when corporations favour projects that make their work easier and more efficient but at the same time represent significant interventions in the ecosystem or the landscape. One environmental organisation representative described the situation as follows:

I think that's probably where the disjuncture between an environmental protection organisation and the corporations is: especially these days, the 
corporations have to be economical, they have to save costs. And when they build roads, for example, they don't pay as much attention to the terrain or don't use gravel anymore. They prefer to use tar, so that they then have no expense for several years. ${ }^{53}$

Interaction and cooperation with the municipal authorities has a long tradition in Sarnen, including by means of the institutionalised annual Martini-Essen (Martini dinner), where municipal, church and corporation councils meet to inform each other about important events of the past year and new projects for the coming year. Concerning land resource use, where interfaces between these different entities have always been high, it was stated that at the beginning of the construction boom in the post-war period, cooperation between the municipal and corporation representatives was good. This seemed to be related to the fact that the corporations (above all the Freiteil corporation in the lowlands, where the demand for building land was highest) frequently offered a hand and willingly made the required building land available at moderate or even reduced prices. However, the external demand for building land steadily increased in the following years, leading to a sharp decline in the Freiteil corporation's land reserves by the end of the 1980s. In the period from the 1960s to the 1980s, the pressure placed by the municipality on the Freiteil corporation seemed considerable: "The municipality called and said that we have to clear this area, because there will be an industry that provides the jobs they need". ${ }^{54}$ With this, the feeling arose that the corporations were not being respected and that they must play the role of "cheap land uncle", 55 encouraging them to move closer together and report more actively on their activities. Consequently, cooperation improved once again. One municipal representative stressed this change of attitude towards greater mutual support and exchange as follows:

We [as a municipality] are often dependent on them [the corporations] and vice versa. It is simply a give-and-take. And we have developed a certain partnership, a certain trust now, especially as far as land issues are concerned. [...]. One tries to find solutions. A corporation has never come to me and said, "I don't really care what you do as a municipality". From our side, it is of course also like this. Because, in the end, we are all in the same boat, different views in part, somewhat different backgrounds and other concerns, but in the end, we work as a community. ${ }^{56}$

This statement was mirrored by that of a former corporation representative, who said that the four corporations improved cooperation to increase their bargaining power:

Nowadays we clearly have much, much better cooperation with the municipality. [...]. We have worked hard in this direction, to connect the corporations, to speak with one voice, so that it is not each corporation 
just tending its own garden [...]. We four Sarnen corporations, we are corporation citizens, we represent something to the outside world. We also say that we want to help shape the community. ${ }^{57}$

As a general conclusion in this context, it becomes clear that the aim from all sides is a balanced bargaining power constellation that benefits all sides. The corporations have managed to reposition themselves in society and have been largely able to retain their functions and structures vis-à-vis other political levels. However, the interactions described can be characterised by a certain tension between cooperation and resistance to new developments. Consequently, certain claims from the outside that are changing the relative prices of the land and related common-pool resources will remain a challenge in the future. Examples include spatial planning and housing, where the different priorities or time horizons of the municipality and the corporations are issues of debate (see below), or with regard to nature protection and natural hazards prevention. Swiss waterbodies, as an example of the latter, will again be given more space to fulfil their diverse tasks (e.g. flood protection). This is to be achieved, among other strategies, by securing and extensively managing the legal spatial requirements for waters [Gewässerräume].$^{58}$ Such endeavours affect corporation lands and imply long-term negotiation processes, such as regarding compensation measures.

\section{Corporation-internal interactions}

Bargaining power with regard to internal corporation structures and interactions is ambiguous, above all regarding agriculture and alpine pasture use. Whereas the number of farmers has decreased significantly in all four corporations, their spatial impact is still high and the constitutional objectives of the corporations remain focused on agriculture (and forestry). Until now, decision-making in the annual corporation assembly (Korporationsversammlung) was described as generally in favour of sustaining alpine pasture use and of other citizens supporting the corporation farmers (see also Jedelhauser 2018: 102f.). Examples of such decisions include the construction or renovation of alpine huts in order to maintain pasture use under new legislation related to animal welfare or for comfort reasons for herders (Figure 7.8). This focus on agriculture (and forestry) is linked to the fact that the corporations are dependent on these two basic resource uses when seeking to fulfil their major objectives and to maintain legitimacy in the eyes of the outside world (see below).

Furthermore, the direct payment system has contributed to the empowerment of farmers over the corporations: the fact that direct payments mostly go directly to the farmers themselves (the exception being when alpine pastures are managed by the corporation itself, whereby the corporation can keep up to $20 \%$ of the direct payments for summering ${ }^{59}$ ) has impacts on corporations' room for manoeuvre. For instance, payments for biodiversity protection, for example, contributions for mowing species-rich green and litter (Streue) areas 


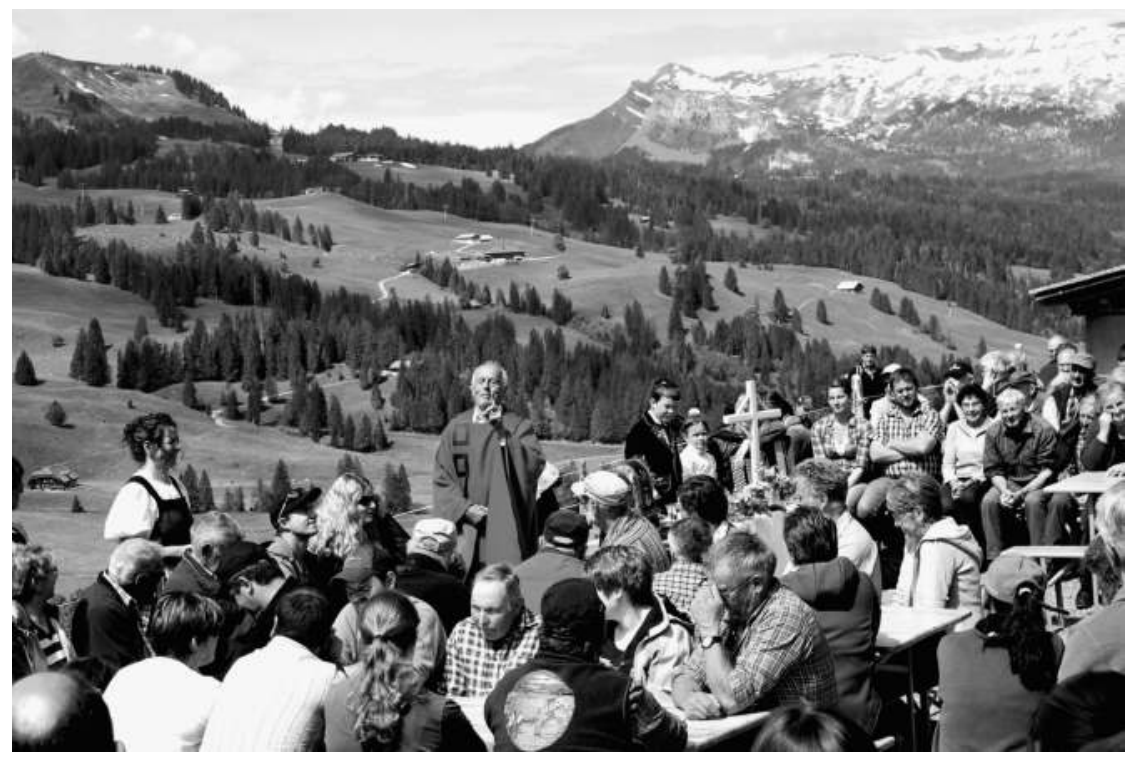

Figure 7.8 Inauguration of a new alpine hut. Source: Picture by Walter Abächerli, 2018.

in the summering area, are on the one hand an important part of farmers' income, decisively (!) contributing to the upholding of land use, a major objective of the corporations. On the other hand, the corporations themselves are said to be "externals" with regard to financial contributions and decision-making. As one former corporation forester succinctly explained:

This is actually one of the craziest laws, the contributions that farmers now get for litter mowing. One hundred and fifty thousand Swiss francs come into the region every year and the corporation does not get a cent of it. The owner is expropriated. ${ }^{60}$

Additionally, with the growing availability of free pastures in other municipalities or cantons, farmers have the option to choose alternative alps for summering, which again increases the pressure on local corporations to comply with farmers' needs, such as by keeping summering fees at a low level. Other voices stressed that farmers are not in as privileged a situation as one might believe, as such state contributions mainly cover their additional workload.

At the same time, the interest among corporation citizens in the corporations' daily business, above all due to the growing proportion of non-farming citizens, was said to be changing and becoming more fractured:

Basically, of course, the farmers are interested in the corporation. Simply because they profit the most. And with the others, they are quite diverse. 
Some are not really interested, they just come to pick up the 100 francs once a year. And the others have a more or less good opinion. There are of course those who always complain, but others actively cooperate. It is quite diverse. But basically, I have the feeling that we have good acceptance from all sorts of people. But you have to work for it. ${ }^{61}$

It remains to be seen how far the focus on farmers' needs will (and can) be supported in the future. Currently, it seems that the "status quo" is being maintained: that a critical mass that would like to change the system, for example, towards a further prioritisation of forces with regard to agriculture or forestry, has not been reached. Individuals' initiatives to change the situation do not always seem to receive widespread approval: "It is often the case in corporations: someone who wants to impede something or starts an initiative [to change something] alone is not necessarily regarded as a good citizen, as a good corporation citizen among the other citizens". ${ }^{62}$ In the Ramersberg corporation, for instance, one representative regarded the resistance of the corporation assembly to change summering rules as a big problem. Also, in the view of a municipal representative, the corporations are very resistant to (fast) changes:

I think the pressure to change is not so great in the corporations. What would happen to them? If an alp is given up because it's no longer profitable, then it just grows in. Nothing happens. It's not some million-dollar investment. That's why I believe that if you want them to transform themselves, I think they'll say "No, we're fine the way we are now". ${ }^{63}$

Nevertheless, this statement also shows that the rationales of outsiders ("it just grows in and nothing happens") and corporation citizens ("corporations as custodians of the land"; see following section) are quite different.

\section{Ideology}

All Sarnen corporation representatives considered the corporations as custodians of the land and their properties. Sustainability or the corporation-inherent characteristic of sustainable natural resource use was a common narrative among the corporation members. This not only referred to "traditional" corporation resources such as forest and pastures, but also to former agricultural land and (potential) building land. Referring to the latter, a former corporationpresident explained the corporation's philosophy when dealing with such pressures on the land:

The canton's low tax strategy created a huge demand for building land. [...]. As president of the corporation, I got phone calls like this: "Have you got land, we're looking for building land, we'll pay this price". In certain circles, the corporation was the self-service shop for building land. And then you had to say, “It doesn't work like that". You can't just build up all 
building land in one fell swoop. So what does the next generation have? That is the corporation mindset, which is sustainable, which is slow, which only gives little pieces. Not everything at once. ${ }^{64}$

Sustainability was, however, not only a corporation-internal narrative, but was also attributed to the corporations from the outside. Indeed, as early as the 1980s, in a report about the Sarnen corporations, a municipal clerk stated that the corporations were every day proving to be able to use forests and pastures sustainably and for the good of the community. ${ }^{65}$

Narratives regarding corporation resources today not only focused on utility (at least among the corporation representatives), but also on the environmental and landscape services that corporations are providing. This may have something to do with the problem of the decreasing market value of resources such as wood, but also with the decreasing dependency on user rights among the majority of the corporation citizens ${ }^{66}$ and the legitimisation pressure imposed by non-corporation-citizens. One corporation representative summarised this dynamic as follows:

Selling wood no longer provides an income for the corporation; in principle it is still cost-covering. What we do with the forest - and therefore is our priority interest - is really to maintain this forest with its protective function and recreational function for the following generations. So that it is not lost, not destroyed. That is our function today. ${ }^{67}$

The "sustainable use of resources" and the rather new "landscape conservation" narratives were also commonly linked to the collective character of the corporations:

Corporations are of great importance when we look at what is being achieved in landscape conservation. In other words, be it the alps, be it the forests or be it the preservation of green spaces within or on the edge of a community. In a corporation that thinks very long-term, land is managed much more sustainably than when it is in private hands. ${ }^{68}$

At the same time, corporations' landscape conservation ideologies were put in contrast with (hypothetical) municipal sovereignty over the resources:

If it were not the corporations that did this, if the forest no longer belonged to the corporations, but to the municipality or canton, for example, then this would always go into the big budgeting processes and then savings would be made. And where do you save? Where you are least affected or not affected in the short term. And the maintenance of the alps and the forests would be judged only on the basis of cost factors and neglected accordingly. ${ }^{69}$

Such statements partly contradict the often controversial negotiation processes with other actors, such as concerning nature and landscape protection, where "utility" and "economic efficiency" again enjoyed considerable importance 
among the corporation citizens. Furthermore, by building on agricultural land, a valuable resource is lost to agriculture, which may be seen as contradicting - in principle - the corporations' traditional objectives. As a form of "compensation" for such strategies, economic necessity or the positive societal impact of such strategies (e.g. affordable housing) were advocated (see below).

The narrative shift to landscape may however also be linked to the decreasing professional link to the resources for the majority of the corporation citizens:

The relationship to alpine pastures in the corporation may change, but it will remain strong. It may in the future no longer be given only by agriculture, but by the need to move and relax in a beautiful landscape. And this great need for nature will not diminish. ${ }^{70}$

Within these developments, above all alpine pastures, but also forests, are also gaining new symbolic meanings, especially in the most urban corporation: "The Alp B. [name of an alp] is really a very good and beautiful alp. You actually still can sense it among the corporation citizens. So the Alp B., that is a sanctuary". 71 "It's a source of pride, a certain pride, yes". ${ }^{72}$

On the part of farmers, the concrete use of resources is of course more prominent (see also Jedelhauser 2018: 106f.). Alpine pastures feed their livestock for more than three months of the year and set free the workforce that is needed to produce fodder for winter in the lowlands. Furthermore, direct payment mechanisms currently support livestock summering. Nevertheless, the alps have an important identity value for the farmers, as well; above all, for those who summer livestock themselves. One farmer described his relationship with his alp as follows:

The fresh awakening of nature, the whole life up here. When you first go up to the alp and see how brown everything is. And a little later, the variety of orchids, the diversity of species up here. And you also notice with the cattle, when you can let them out for the first time, how they have joy that it starts again. And every spring there is a tingling sensation in me, too, when I can go up, when the snow is gone and I can make the fences again. It's just the vastness up here. Yes, that's simply wonderful. ${ }^{73}$

Contrary to some external views (see above), the maintenance of a cultural landscape in the corporations obviously has additional dimensions (e.g. heritage, beauty, freedom, responsibility) including social responsibility and sustainability.

Further new narratives that can be linked to ideology were related to the new societal functions of some of the corporations, such as the provision of (affordable) housing. In the corporation-internal view, this was articulated as follows: 
We have about 140 leases and we consciously also provide low-cost housing. For example, here, in this residential complex, we do not demand the highest rent but try to set it a little lower. By doing this, we also show our relevance, that we are also doing something for the people. ${ }^{74}$

One municipal representative commented on the corporations' new societal functions by stressing their wider room for manoeuvre:

A corporation is not like a municipality that is relatively strongly standardised and structured. From that point of view, for example with regard to forest, forest management, I see the corporation as being in the right place. And as far as the alps, agriculture and such things are concerned, it's also good here if they do that. And personally, I am also glad that the corporations are also taking over the construction of affordable housing, because that is not the core business of a municipality. We have completely different legal requirements. [...]. A corporation can operate quite differently. ${ }^{75}$

Other narratives referring to ideologies were related to abstract concepts such as "belonging", "identity" and "homeland". The corporation representatives assumed that the citizens' relationship to the corporations will change in the future, but were fairly confident that a certain relationship will remain:

The next generation's relationship to the corporation may no longer be directly based on agriculture, as it was in previous generations, but rather on the relationship to the homeland (Heimat). The origin, the rootedness, has regained in value among young people. ${ }^{76}$

From this, it can be assumed that commoners' organisations are also perceived as a means of reproducing identity or a sense of belonging in the future.

Nevertheless, given that the close link to the resources was said to be diminishing, above all among the more urban population of the Freiteil corporation region, some corporation representatives also expressed doubts concerning the future relationship between people and land:

Who below in Sarnen still has an identification or a passion for the few farmers who are still there? You only notice it when they spread liquid manure, then it stinks, doesn't it? [...]. Farmers are becoming exotic, more and more. And every [farming] family that doesn't have a child who grows up with agriculture will have a problem. They'll always find a tenant, but that's not the same: identification with our history and our ways of managing resources is dwindling. ${ }^{77}$

At the same time, most of the respondents were confident that the cooperative system will not die. Some even expected the value of natural resources to rise again in the distant future: 
If you find a few people, a small group that is proactive and works with heart and soul, then our system will live for a long time. It can survive for decades and suddenly perhaps a certain self-sufficiency will become important again: that you can have fruit trees, cheese, milk, potatoes yourself. ${ }^{78}$

This again relates to the long-term perspective, which was said to be a core characteristic of the corporations and which is the central aspect of ideology that renders the commoners' organisations robust. However, as the four corporations are facing quite different situations, above all regarding changes in economic structure and actual organisational situation, ideologies have different functions. Above all, legitimisation narratives towards the outside are dependent on the "gap" between new ways of generating income and the connotation of corporations as the custodians of "traditional" natural resources (see below).

\section{Common social, political and economic strategies}

Based on the previous sections, the following developments can be seen as having had a major impact on the corporations and having added to temporal vulnerability: declining incomes from the use of forests and agricultural land, the decreasing proportion of corporation citizens among the general population and the diminishing relation of the general population and the corporation citizens to the concrete use of natural resources (agriculture, forestry). Other vulnerabilities are corporation-specific, such as the financial constraints of the Ramersberg corporation or the label of being a "privileged community" and related legitimisation issues faced by the Freiteil corporation. At the same time, external support for societal services (e.g. hazard protection, cultural landscape maintenance, nature protection) has contributed to the perpetuation of the system, but has also (due to the increasing importance of public policies) led to the increased steering of land-use issues from the outside and the need of the corporations to adapt to these changes and to renegotiate their own concerns.

As a result of such developments and the diverse characteristics of the four corporations, transformational change, as shown in the previous sections, has taken different forms in recent decades. Additionally to those partly independent and corporation-specific fields of action, adaptive and proactive coping strategies as well as new institutional designs of a more overarching nature and that also include common actions by all corporations have been key to the corporations' capacity to increase resilience. Examples of such new common institutional designs and strategies include:

- Collaboration and cooperation among the four corporations. Major achievements in this field comprise the establishment of a common forestry consortium that includes all of the corporations as well as close collaboration (a "common voice") when dealing with external actors in order to increase the corporations' bargaining power, above all vis-à-vis the municipality and the canton. 
- Engagement on behalf of the general public, or, in other words, the rendering of services to non-commoners. This includes, for instance, the running of a restaurant or a hotel, the provision of affordable housing or the operation of a common foundation for the youth (Jugendstiftung).

- Communication regarding the outcomes of corporation engagement to a wider public ("do good and talk about it"). Major achievements here include the establishment of corporation websites, the production of professional annual reports for internal and external communication and the common communication of corporation themes and issues in the local newspaper.

- Mutual support between the corporations. This includes, above all, the financial assistance of poorer corporations by more wealthy ones in the case of emergencies as well as the provision of administrative services among the corporations.

From the point of view of the persons interviewed, this "crafting of alliances" has contributed to the ability to have a greater impact on the societal, political and economic environment and has thus increased resilience. For example, the establishment of a common forestry consortium in 2001 involved a long-term process of negotiation, but ultimately led to an organisational structure that was able to create economies of scale. As one corporation representative explained:

We have the ARGE Forst [Arbeitsgemeinschaft Forst; forestry consortium] together now. The voting weight is regulated according to the forest area and not according to the financial strength of the individual corporation. This cooperation really makes sense. Otherwise, each corporation would only do one-man forestry operations and would have to have all the machinery and everything. It really makes sense to manage it professionally together. ${ }^{79}$

With regard to the strengthening of connections with non-commoners, three of the four corporations have taken over a restaurant or a hotel in recent decades. Such an engagement is related to the hope of certain corporation officials to generate income (which later proved to be wrong), the increased struggles of former private restaurant or hotel owners to profitably run such a business and/or corporation citizens' sense of responsibility to maintain certain social infrastructure in their villages. As one corporation representative explained,

With the hotel-restaurant we also give something back to society. We know that we do not earn money with it. We put money on it, as you can see in the annual accounts. We actually do this for the benefit of the public. ${ }^{80}$

Other means of connecting to the outside include things like motivating people to participate in "modern communal work" or to contribute financially. Regarding 
the latter, a donation for the renovation of a cheese cellar in the Ramersberg corporation is compensated with the right to obtain a kilogram of cheese every year for life. This new way of inclusion additionally comprises a social event, referring to an adapted version of the traditional Chästeilet, the dividing of the produced cheese among the cattle owners at the end of the alp season.

As for new communication strategies and efforts, these were viewed by the corporation representatives as a success story of improving - or rather rectifying - the corporations' image among non-citizens:

That these corporations administer all the assets among themselves while the non-citizens are ignored was actually the image people had of the corporations before. And that has changed. When I get feedback now, they say, "Now I finally know that you are maintaining the alpine pastures, now I know who is responsible, who is foresting after a storm; now I know who is organising the river constructions and that we can use bike paths in a beautiful area and [we know] that the hiking trails are being maintained". This is all connected to the work of the corporations. ${ }^{81}$

How far this view is applicable to a broader population was beyond the focus of the current research. Nevertheless, first indications imply that this is only true for one part of the (already interested) population.

Finally, mutual support between the corporations was perceived to be contributing to the stabilisation of the whole system. Or, in the words of one corporation representative, "One has to support the poor corporations, also financially, because if one corporation does not make it, the whole system is called into question". ${ }^{82}$

\subsection{Conclusions}

The Sarnen corporations' system has undergone significant transformational changes in recent decades. The main driving factors were (and still are) general societal changes, changes in public policies, compensation mechanisms, market prizes for goods and factors internal to the commoners' organisations. With regard to the natural resources that are under the corporations' stewardship, on the one hand, a shift in relative prizes from market mechanisms (own use and/or selling of agricultural and timber products) towards compensated ecosystem and landscape services (e.g. direct payments for summering and protection forest) is obvious. On the other hand, the corporations have allocated new income sources by integrating themselves into new markets (e.g. real estate). Such new economic activities have significantly changed the income structure of the majority of the corporations and have contributed to their diversification.

Closely linked to these changes, the transformational change of the Sarnen corporations has included a shift in other organisational fields and in the dimensions of institutions and bargaining power. Through such internal adaptations (and particularly through their common social, political and economic actions), 
the corporations have been able to uphold their position within society. Such processes have involved a reproduction and adaptation of ideology (e.g. corporations as custodians of the land and as important actors in national, cantonal and municipal issues, such as nature protection, spatial planning and housing) in order to reproduce legitimacy. However, the legitimisation pressures have differed between the corporations that have significantly changed their economic base on the one side and the corporations whose main economic base comprises "traditional" resources on the other. For instance, by diversifying their income sources, the most urban corporation Freiteil as well as Schwendi and Kägiswil have become more resilient to economic stress or volatility of relative prices. However, with this economic shift, Freiteil above all must cope with a certain tension between actual practices that produce considerable wealth and an ideology that renders the corporation more vulnerable with regard to the external perception of being a closed and privileged community. The Ramersberg corporation, on the other hand, has not changed much with regard to organisation and focus, rendering it vulnerable with respect to economic room for manoeuvre, while at the same time making actual activities and ideology relatively congruent, which may add to resilience in this particular field.

Nevertheless, several factors are creating obstacles that may compromise corporations' resilience. Policies that support individual households such as agricultural direct payments have the potential to hamper corporations' bargaining power. At the same time, with the decreasing number of farmers among the corporation citizens as well as internal demographic changes (age, background, relation to agriculture) and the loosening link to agriculture, farmers may also face more obstacles in the future, such as with regard to investments in agriculture. As corporations are dependent on farmers' use of the land, up to now corporation citizens have acted very favourably in relation to agriculture and forestry. This relates to the corporations' constitutional rights and duties to manage their property of alpine pastures, common agricultural land, forests and other corporation property in the interests of the corporation and for the benefit of the general public. If they should shift their focus away from land management or if the suspicion should arise that corporations are unduly favouring their citizens, this would again raise the question of their legitimacy. This threat is accentuated with the decreasing proportion of corporation citizens in the municipality, the remaining exclusive citizenship as foreseen in the constitutional rights of the corporations and the ignorance of a large part of the population to the services the corporations provide to society. However, with the common strategy of "do good and talk about it", corporations have recently institutionalised a progressive way towards the future and are trying, among others, to counteract such suspicions from the outside.

Regardless, it needs to be stated that corporations - and above all their active citizens - are investing considerable effort and a large part of their workforces into the system. In order to be able to cope with the diverse tasks of a corporation, dedicated people form the backbone. Their work efforts for the good of the corporation but also for the general public and nature are only 
partly compensated. This also means that for the sustainable use of natural resources and the provision of ecosystem and landscape services, commoners' organisations with a strong social structure and cohesion, like the Sarnen corporations, are indispensable. Such tasks would hardly be fulfilled should the use of natural resources be privatised or put under public (municipal, cantonal, state) ownership. Whether this kind of cohesion would be hampered if new citizens were to be admitted remains an open question. In the view of the corporation representatives, this could well occur.

With regard to sustainability transformation processes and the focus on the sustainable use of natural resources, the corporation system has the following strengths: (a) a long-term perspective due to a focus on preserving resources and on keeping the resource base for future generations of commoners rather than on making a profit; (b) fast reactivity/responsiveness due to straightforward small structures and organisational freedom, while at the same time acting as a brake against too fast and too fundamental changes; (c) closeness to everyday life of the users due to grounded regulations; (d) strong identification potential and sense of place and ownership due to closed, long-standing entities and, based on that, dedicated corporation officials and other citizens; (e) ideology of custodians of an inherited (beautiful) landscape; and (f) new (external) appreciation for corporations' important role in providing landscape services.

The most important fields of tension and vulnerabilities in transformation processes can be identified in the following fields: (a) dependency on state contributions; (b) field of tension between economic efficiency due to economic pressures and the objective of long-term provision of resources; (c) field of tension between new responsibilities and regulations (e.g. nature protection) and persistence of traditional structures; (d) decreasing connectedness to the general public due to severe citizenship regulations; (e) decreasing connection with resources due to societal change, the diminishing group of users and the loosening link of citizens to concrete resource use; (f) decreasing agency of corporations due to land lease and because direct payments go directly to the farmers; (g) dependency on a small group of users; (h) high workload of the corporation officials and presumably increasing difficulties to find successors; (i) field of tension between internal or external claims for modernisation and preservation of long-standing structures; and (j) gaps between new ways of income generation and the connotation of corporations as the custodians of "traditional" natural resources.

To sum up, in a changing societal, political and economic environment, the Sarnen corporations have experienced diverse pressures, under which they have not only adapted, but have also been able to transform themselves in order to remain important players in the local context. Nevertheless, a transformation process challenges commoners' organisations to continuously find the right balance between self-determination and adaptation in dealing with the "outside world", as could be seen for example with regard to the introduction of nature protection policies coming from the outside. State modernisation thus has the potential to destabilise traditional structures for a certain time 
period, but also to make commoners' organisations resilient again in the course of the adaptation and transformation process. At the same time, by positioning themselves as reliable partners both in maintaining ecosystem and landscape services and in societal matters, commoners' organisations can contribute to sustainable development by maintaining a dynamic diversity of structures and by providing locally adapted and grounded means of dealing with contemporary ecological and societal challenges.

\section{Acknowledgements}

My work would not have been possible without the outstanding support of Ariane Jedelhauser (master's student), Deborah Jutzi (research assistant), Beny Kiser (Korporation Ramersberg), Walter Abächerli and Vreny Schädler (Korporation Schwendi), Niklaus Wirz and Patrick Imfeld (Korporation Freiteil), Hanspeter Lussi (Korporation Kägiswil), Mario Seger (Staatsarchiv Obwalden) and Klara Spichtig (Historisches Museum Obwalden). My sincere thanks also go to the people who made themselves available for the interviews, to my research colleagues and to all the other people who have supported me over the past few years.

\section{Notes}

1 Flysch: a sequence of sedimentary rock layers, characteristically soft and relatively impermeable.

2 Mire landscape (Moorlandschaft): a mire is a wetland type, dominated by living peatforming plants. Consequently, a mire landscape is a landscape that contains a diverse pattern of partly forested mires, often in alternation with lands that are grazed or mowed.

3 Verfassung des Kantons Obwalden (Kantonsverfassung) vom 19. Mai 1968 (Stand 1. Januar 2018).

4 see e.g. Der Swandern Einung 1471; in Sigrist and Älplergesellschaft Schwendi 1999: $17 \mathrm{ff}$.

5 In the local context, membership of a corporation is literally translated by as "corporation citizenship" (Korporationsbürgerschaft). Therefore, I will use this local term for describing membership in a commoners' organisation.

6 Bundesgesetz betreffend die eidgenössische Oberaufsicht über die Forstpolizei im Hochgebirge, 24. März 1876.

7 Vollziehungsverordnung zum eidgenössischen Forstgesetz 1877.

8 Waldreglement der Theilsame Schwändi 1879.

9 Holzordnung oder Waldreglement für die drei Theilsamen Freitheil, Kägiswil und Ramersberg 1887.

10 Einung über das Theilenrecht der Schwendi oder Grundsätze über die Benützung und Verwaltung des Theilen- und Corporationsgutes in Revision des alten Einungs genehmiget von der unterm 19. März 1876 zahlreich versammelten Theilern unter Empfehlung des von unsern lieben Altfordern ererbten Gemeingutes in den Schutz des allmächtigen Gottes, Sarnen 1876.

11 Original: "Der junge Waldwuchs ist möglichst zu begünstigen, der wachstumsfähige zu schonen und der jährliche Gebrauch dem Waldvorrate möglichst so anzupassen, dass die Nachkommen nicht in Schaden und Holzarmuth gerathen". 
12 Bundesbeschluss betreffend die Förderung der Landwirtschaft durch den Bund vom 27. Juni 1884.

13 Kanton Obwalden: Staatsbeiträge an Bodenverbesserungen, Land- \& Alpwirtschaft, Verordnung des Kantonsrates vom 27. November 1897.

14 Rekurs gegen den Beschluss der Teilenversammlung von Ramersberg vom 12. Januar 1919 (source: Staatsarchiv des Kantons Obwalden).

15 Rekurs namens Josef Kiser, Senn, bezw. seiner Söhne: Josef, Balz u. Leo Kiser, Kägiswil gegen Einwohnergemeinde Kägiswil (...) an die h. Regierung von Obwalden, Sarnen vom 6. Juni 1927 (source: Staatsarchiv des Kantons Obwalden).

16 Verordnung vom 16. Juni 1980 über Bewirtschaftungsbeiträge an die Landwirtschaft mit erschwerten Produktionsbedingungen (Verordnung Bewirtschaftungsbeiträge).

17 Bundesrat der Schweizerischen Eidgenossenschaft. 1992. Siebter Bericht über die Lage der schweizerischen Landwirtschaft und die Agrarpolitik des Bundes (7. Landwirtschaftsbericht). Bern.

18 Bundesgesetz vom 3. Dezember 1850 die Heimatlosigkeit betreffend.

19 Source: Annual reports of the corporations (year 2017).

20 Interview with corporation representative, 21.06.2017.

21 Interview with corporation representative, 05.07.2017.

22 Einung Korporation Freiteil, 2009.

23 Interview with corporation representative, 05.07.2017.

24 Interview with corporation representative, 31.05.2017.

25 Interview with corporation representative, 05.07.2017.

26 Interview with corporation representative, 05.07.2017.

27 Einung der Korporation Schwendi 2008.

28 Group discussion with corporation representatives, 14.12.2017.

29 Einung der Korporation Freiteil Sarnen vom 17. November 1976.

30 Einung Korporation Freiteil Sarnen vom 14. Mai 2009.

31 Korporation Schwendi, Oberallmendverordnung, 2017, Art. 3., Art. 10, Art. 24. Korporation Ramersberg, Allmendverordnung, Kap. 5.2.

32 Bundesgesetz betreffend die eidgenössische Oberaufsicht über die Forstpolizei im Hochgebirge, 24. März 1876.

33 Interview with cantonal representative, 27.06.2017.

34 Interview with corporation representative, 21.06.2017.

35 Interview with corporation representative, 31.07.2018.

36 Verfassung des Kantons Obwalden (Kantonsverfassung) vom 19. Mai 1968 (Stand 1. Januar 2018).

37 However, not all eligible people apply to become corporation citizens. Consequently, there are more eligible people in the Sarnen municipality than are effectively corporation citizens.

38 Interview with corporation representative, 31.05.2017.

39 Interview with municipal representative, 28.01.2019.

40 The civic community (Bürgergemeinde) is a personal body under cantonal public law, which still exists today in about half of the Swiss cantons. Irrespective of one's current place of residence, it is made up exclusively of natural persons who have the status of citizens and thus the home rights of this (civic) community. Unlike the political municipality, the civic community has neither a specific territory nor fiscal sovereignty, but often has considerable assets (Auer 2016).

41 Apparently, however, a calculation of costs and benefits by the municipality led to the conclusion that a shift of responsibilities from the corporations to the municipality would be disadvantageous for the latter.

42 Interview with former corporation president, 29.08.2017.

43 Interview with corporation representative, 31.05.2017.

44 Motion betreffend Bearbeitung der kantonalen Naturschutzgebiete laut Richtplan durch die Fachstelle für Natur- und Landschaftsschutz von Kantonsrat Erwin Odermatt (Kantonsratsprotokoll 5./6.9.1996). 
45 Interview with former forester, 22.06.2018.

46 Interview with cantonal representative, 27.06.2017.

47 Interview with corporation representative, 27.06.2017.

48 Interview with former forester, 22.06.2018.

49 Interview with corporation representative, 27.06.2017.

50 Interview with corporation representative, 31.07.2018.

51 Interview with corporation representative, 27.06.2017.

52 Interview with environmental organisation representative, 22.01.2019.

53 Interview with environmental organisation representative, 22.01.2019.

54 Group discussion with corporation representatives, 14.12.2017.

55 Conversation with two corporatation representatives, 07.05.2020; written exchange with corporation representative, 27.05.2020.

56 Interview with municipal representative, 28.01.2019.

57 Interview with former corporation representative, 11.01.2018.

58 See: Bundesgesetz über den Schutz der Gewässer (Gewässerschutzgesetz) vom 24. Januar 1991 (Stand am 1. Januar 2020) (Federal Act on the Protection of Water of 24 January 1991 (status as of 1 January 2020)), Art. 36a

59 Verordnung über die Direktzahlungen an die Landwirtschaft (Direktzahlungsverordnung, DZV) vom 23. Oktober 2013 (Stand am 1. Januar 2020), Art. 109, Abs. 5.

60 Interview with former forester, 22.06.2018.

61 Interview with corporation representative, 27.06.2017.

62 Interview with former alpine farmer, 26.09.2018.

63 Interview with municipal representative, 28.01.2019.

64 Interview with former corporation representative, 11.01.2018.

65 Gemeindekanzlei Sarnen. 1984. Über die Korporationen von Sarnen. Unpublished report (page 9).

66 In the view of the direct users, however, utility is still a guiding principle, as expressed in narratives regarding fodder availability and wood prices.

67 Interview with corporation representative, 31.07.2018.

68 Interview with corporation representative, 21.06.2017.

69 Interview with corporation representative, 31.07.2018; confirmed in a written conversation on 08.05.2020.

70 Group discussion with the corporation representatives, 14.12.2017.

71 Interview with corporation representative, 21.06.2017.

72 Interview with corporation representative, 21.06.2017.

73 Interview with farmer, 19.08.2017.

74 Interview with corporation representative, 21.06.2017.

75 Interview with municipal representative, 28.01.2019.

76 Group discussion with the corporation representatives, 14.12.2017.

77 Interview with corporation representative, 31.05.2017.

78 Interview with corporation representative, 31.05.2017.

79 Interview with corporation representative, 05.07.2017.

80 Interview with corporation representative, 21.06.2017.

81 Interview with corporation representative, 31.07.2018.

82 Interview with corporation representative, 21.06.2017.

\section{References}

Abächerli, A. (1951) Die Alpwirtschaft im Kanton Obwalden. Lungern: Verlag Burch \& Cie.

Abächerli, B., Amgarten, M., and Ettlin, N. (2004) Alpwirtschaft in Obwalden: Heute und Morgen. Expertenbericht. Sarnen: Landwirtschaftsamt Obwalden.

Amt für Landwirtschaft und Umwelt (ed.) (2005) Empfehlungen zur Vergabe von land- und alpwirtschaftlichen Flächen und Alpen durch öffentlich- und privatrechtliche Körperschaften im Kanton Obwalden. Sarnen: Amt für Landwirtschaft und Umwelt. 
Auer, A. (2016) Staatsrecht der schweizerischen Kantone. Bern: Stämpfli.

Bisang, K., Moser, T.A., Zimmermann, W., and Landolt, D. (2008) Erfolgsfaktoren in der Naturschutzpolitik: Beispiele aus vierzig Jahren Natur- und Landschaftsschutzpolitik in der Schweiz. Zürich/Chur: Rüegger.

Ensminger, J. (1992) Making a Market: The Institutional Transformation of an African Society. Cambridge: Cambridge University Press.

Etlin, E. (1903) Schweizerische Alpstatistik: Die Alpwirtschaft in Obwalden. Solothurn: Buchund Kunstdruckerei Union.

Flick, U., von Kardorff, E., and Steinke, I. (2004) A Companion to Qualitative Research. London: SAGE.

Garovi, A. (2000) Obwaldner Geschichte. Sarnen: Staatsarchiv des Kantons Obwalden.

Garovi, A., Sigrist, R., Camenzind, O., Wallimann, U., Langensand, O., Wallimann, L., Schwyzer, C., Albert, D., and Jöri, M. (2012) Korporation Alpnach: Von den Anfängen bis in die Gegenwart. Alpnach: Verlag Martin Wallimann.

Garovi, A., and von Flüe, N. (2018) Obwalden. In Historisches Lexikon der Schweiz HLS. https://hls-dhs-dss.ch/de/articles/007410/2018-02-07/ (accessed: 25.06.2020).

Jedelhauser, A.K. (2018) Sarner Korporationen zwischen Tradition und Wandel. Untersuchung des sozioökologischen Systems von Korporationen und Korporationsalpen in Sarnen, OW. Bern: Masterarbeit der Philosophisch-naturwissenschaftlichen Fakultät der Universität Bern.

Kanton Obwalden (2020) Strukturmerkmale des Kantons Obwalden. https://www.ow.ch/de/ kanton/portrait/owinzahlen/ (accessed: 24.04.2020).

Lienert, L. (1981a) Obwalden - seine Landschaft. Schweizerische Zeitschrift für Forstwesen, vol 132, pp. 485-489.

Lienert, L. (1981b) Über die Entwicklung des Forstwesens in Obwalden. In KantonsOberforstamt Obwalden (ed.), Wald und Mensch in Obwalden (pp. 631-650). Sarnen: Kantons-Oberforstamt Obwalden.

Lienert, P. (2010) Obwaldner Forstgeschichte: Basis für eine erfolgreiche Zukunft. Schweizerische Zeitschrift für Forstwesen, vol 161, no 7, pp. 251-257.

Lienert, L. and Wallimann, H. (1963) Pflanzengeographie von Obwalden. Sarnen: Heimatschutzkommission Obwalden.

Norer, R. and Tschopp, S. (2015) Kurzgutachten: Bundesgesetz über die landwirtschaftliche Pacht (LPG); Anwendungsbereich bei Korporationen, Teilsamen und Alpgenossenschaften. Luzern: Universität Luzern.

Obwaldner, Bauernverein (1890) Bericht über Inspektion und Prämierung der Obwaldner Alpen von 1883-1890. Sarnen: Buchdruckerei Jos. Müller.

Omlin, H. (1913) Die Allmend-Korporationen der Gemeinde Sarnen (Obwalden). Der Geschichtsfreund: Mitteilungen des Historischen Vereins Zentralschweiz, vol 68, pp. 1-184.

Rogger, D. (1989) Obwaldner Landwirtschaft im Spätmittelalter. Sarnen: Verlag des HistorischAntiquarischen Vereins Obwalden.

Schweizerisches Landwirtschaftsdepartement. (1914) Das Bodenverbesserungswesen der Schweiz. Bern: Buchdruckerei R.J. Wyss.

Sigrist, F. and Älplergesellschaft Schwendi (ed.) (1999) D'Schwendi: 375 Jahre Älplerkilbi Schwendi 1624-1999. Sarnen: von Ah Druck.

Viallon, F.X., Liechti, K., Stuber, M., and Wunderli, R. (2019) Vermittlung, Einbau, Komplementarität - Formen des staatlichen Zugriffs auf kollektive Weiden und Wälder in der Schweiz im späten 19. Jahrhundert. In Head-König A.-L. et al. (eds), Kollektive Weiden und Wälder - Ökonomie, Partizipation, Nachhaltigkeit / Pâturages et forêts collectifs Économie, participation, durabilité (pp. 125-149). Zürich: Chronos.

Von Flüe, N. (2012) Sarnen: Aus 1000 Jahren Geschichte. Kerns: Eigenverlag. 


\title{
8 Weak commons management, strong identity
}

\author{
The case of Val d'Anniviers (Canton Valais)
}

\author{
François-Xavier Viallon
}

\subsection{Introduction: geographical and current socio-economic components}

The mountainous Val d'Anniviers is a side valley located on the southern bank of the river Rhône in the French-speaking part of the Valais canton, in Switzerland. Peaks over 3000 meters mark the valley's borders in the east and west. The southern peak, Dent blanche (4357 meters), separates Anniviers from Zermatt and Italy. Two deep gorges separate Anniviers from the Rhône valley in the north. The only access to Anniviers was via mule tracks until the 1850s. The terrain is rough and steep. Flat land is almost non-existent and most slopes exceed 30 degrees. The climate is dry and sunny (Reynard 1995). Below the forest line, around 1900 meters, are meadows and pasture, called mayens, with scattered huts formerly used for hay storage. These mayens are subject to land betterment programmes, and are still used as meadows; others have been turned into pasture, and others were abandoned and returned to brush or forest. Forest also grows at the bottom of the Alpine pastures around 2200 meters. A comparison of land use changes between 1983 and 2017 shows a substantial increase in both forests (+12\%) and artificial areas (+61\%) (FSO 2019a). The artificial areas consist of six villages and a dozen hamlets, each historically dependent on a village. These six villages are host to the valley's six bourgeoisies. Vissoie is the central borough of the valley, located at a height of 1204 meters. It is crossed by the road connecting Anniviers' villages to the Rhône valley. The five other main villages are Saint-Jean (1395 m), Ayer (1476 m), Grimentz (1564 m), Saint-Luc (1655 m), and Chandolin $(1920 \mathrm{~m})$. From a planning perspective, the valley counts $3.83 \mathrm{~km}^{2}$ of building zone, of which $2.90 \mathrm{~km}^{2}$ are dedicated to housing. These areas were above all intended for the construction of secondary homes. Currently, between $0.72 \mathrm{~km}^{2}(25 \%)$ and $1.14 \mathrm{~km}^{2}(39 \%)$ of housing areas are undeveloped (FPO 2018). In addition to historical wood and stone constructions in the village centres, the main construction is the individual chalet, today mostly used as a secondary home. 


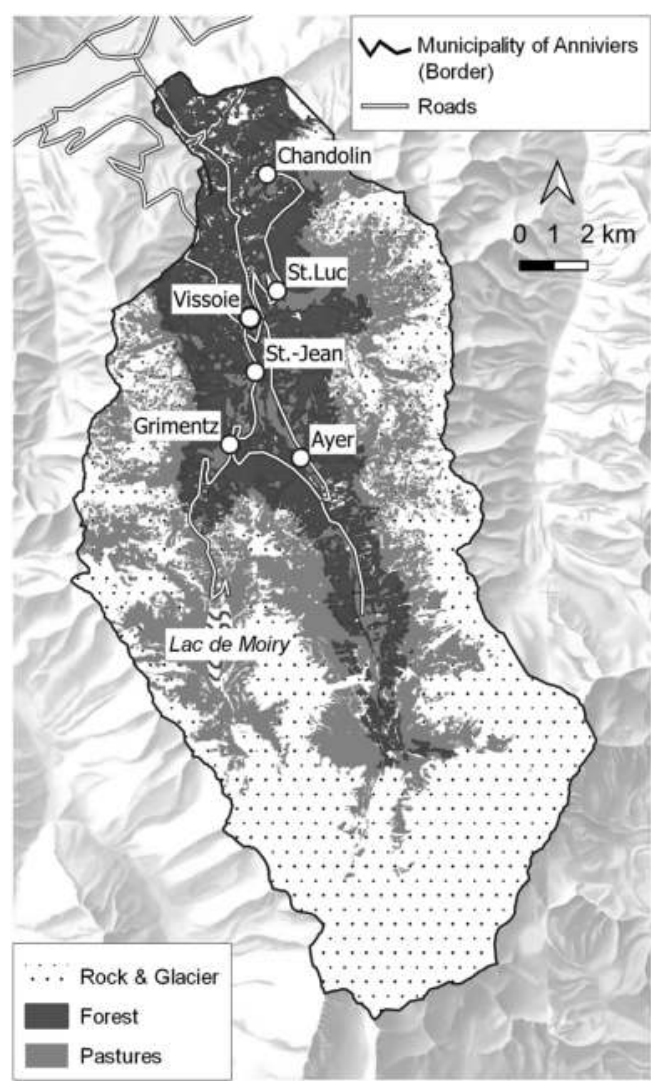

Figure 8.1 Municipality of Anniviers - land cover. Map compilation and design by Sarah Baumgartner, University of Bern. Geodata source: Cantonal Agricultural Office, 2020; Cantonal Land Register 2020; Bourgeoisie d'Ayer 1994. Land cover data: Swiss TLM3D land cove. Hillshade: Relief PK 100, reproduced with permission of swisstopo (BA20043).

The resident population of the entire valley in 2018 was 2732, an increase of 44\% since 1988, and of 22\% since 1900 (OCSP 2018). Ayer, Grimentz, Saint-Luc, and Vissoie are among the most populated villages with over 400 residents each, and Saint-Jean and Chandolin have approximately 250 and 120 inhabitants each. From the beginning of the twentieth century, the increasing attractiveness of wine production, and employment offered by the aluminium foundry and mill in the Rhône valley, encouraged emigration to the foot of the valley. The nearby city and district capital Sierre was a common destination. The valley's population decreased until the 1970s, when it reached a historical low of 1440 inhabitants. From then onwards, tourism development was the primary source of growth, both in terms of population and employment (Chauvie \& Gabbud 2005). Today, the valley of Anniviers forms a single 


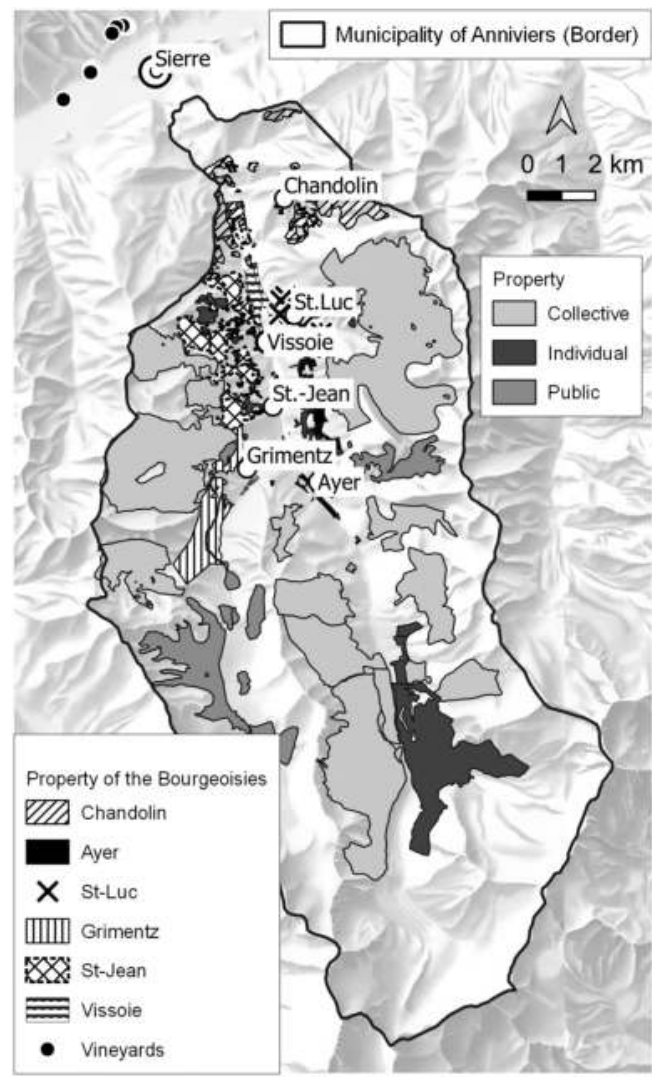

Figure 8.2 Landed property of the bourgeoisies of Anniviers. Map compilation and design by Sarah Baumgartner, University of Bern. Geodata source: Cantonal Agricultural Office, 2020; Cantonal Land Register 2020; Bourgeoisie d'Ayer 1994. Hillshade: relief PK 100, reproduced with permission of swisstopo (BA20043).

municipality defined as touristic, with an average of 418,000 overnight stays per year in the past decade (Municipal Tourism Office 2020). Two-thirds of stays are during the winter for the skiing season, and one third during the summer for hiking, running, biking, and other outdoor activities. The importance of tourism is reflected in municipal spending, where about a fifth of the budget is dedicated to tourism (Interview 28). In terms of employment, the tourism, construction, and agriculture sectors are over-represented compared to the average cantonal and national economic structure. Among the valley's 1133 full-time equivalent jobs, $75 \%$ are in the tertiary sector, $20 \%$ in the secondary sector, and 5\% in the primary sector (FSO 2017). Restoration, accommodation, and ski-lift operation account for a quarter of local employment. The construction sector hosts almost a fifth of local employment and was particularly active in the construction of secondary homes. In 2016, however, 
the Federal Act on Second Homes introduced a limit to the construction of secondary homes in municipalities where secondary homes exceed $20 \%$ of the overall number of homes. With $76 \%$ of homes defined as secondary, the municipality of Anniviers is subject to these restrictions (FPO 2020).

Contemporary socio-economic challenges in Anniviers include support of the valley's touristic attractiveness, the preservation of employment, in particular in the construction sector, the perpetuation of agricultural activities, and the maintenance of the landscape ecosystem (Interviews 11, 13, 16). These last two challenges are directly linked to commoners' organisations, as these hold ancestral rights to the majority of the valley's Alpine pastures and forests. Cantonal legislation distinguishes between two types of commoners' organisations. The first are consortages, private associations formerly composed of peasants, today professionally mixed, holding rights to pastures and water courses. Consortages are private-law corporations defined by the cantonal addendum to the Swiss Civil Code. According to the addendum and the Civil Code, consortages pursue non-commercial goals. They consist of an assembly of right-holders called consorts or allodiateurs. The latter term presumably refers to the alleu, a type of tenure free from seigniory (Blaufarb 2016: 95). Rightholders are entitled to alienate and manage rights to a designated resource, as well as related infrastructure and/or land. The second type of commoners' organisations are bourgeoisies. Bourgeoisies are public law corporations defined by the cantonal law on communes and the cantonal law on bourgeoisies. In the past, they held political, administrative, and judicial competencies and defined core elements of social and economic life in the community. Nowadays, they grant membership to commoners, manage their property, and support works of public interest.



Figure 8.3 Old and new homes in Grimentz. 2018. The author. 
Table 8.1 Types of property rights on commons and modalities of transfer and possession

\begin{tabular}{lll}
\hline $\begin{array}{l}\text { Modalities of transfer and } \\
\text { possession } \\
\text { Property rights on }\end{array}$ & $\begin{array}{l}\text { Transferable and cumulative } \\
\text { (Consortages) }\end{array}$ & $\begin{array}{l}\text { Inheritable and non-cumulative } \\
\text { (Bourgeoisies) }\end{array}$ \\
\hline Resource & $\begin{array}{c}\text { Grass of pasture, water from } \\
\text { irrigation channels, trees, } \\
\text { vine }\end{array}$ & $\begin{array}{c}\text { Grass of pasture, water from } \\
\text { irrigation channels, trees, } \\
\text { vine }\end{array}$ \\
Constructions on pasture, & $\begin{array}{c}\text { Constructions in forest, } \\
\text { constructions on pasture, cellars }\end{array}$ \\
Land & Land of community barns & \begin{tabular}{l} 
Forest, vineyard \\
\hline
\end{tabular}
\end{tabular}

Consortages and bourgeoisies have different ownership rules regarding resources (see Table 8.1). Commoners in consortages may hold one or several property rights to a resource. They may acquire and sell their rights individually. The assembly of commoners generally holds a pre-emption right on transactions. In contrast, commoners in bourgeoisies hold property rights to a resource only through membership of the bourgeoisie; they do not have an individual property title. They may inherit membership from their parents, or obtain it through acquisition, or through marriage. Decisions about the alienation of rights to the resource are decided by the assembly of commoners using the one-person, one-vote rule. Depending on the type of resource, and the type of organisation considered, property rights held by commoners may include rights to a resource, to infrastructure, and/or to land. Property rights associated with pastures and irrigation channels only involve the resource and its infrastructure; it excludes rights over the land (for irrigation channels, see Schweizer 2013), which is public domain, or the property of another landowner. One may compare such property rights to an easement on land (Schweizer 2014). This situation has arisen from the preservation of immemorial rights by the Civil Code. The situation differs for property rights to forests, community barns, and vineyards. The owners of these resources own both the infrastructure and the land, except where specified otherwise. Table 8.1 summarises the different types of property rights to commons in Valais, as well as the modalities of their transfer and possession.

The case of Anniviers shows how the political power and economic relevance of commoners' organisations evolved over centuries, and adapted to the emergence and development of the nation-state. Major changes in relative prices, structural transformations in agricultural production, and substantial losses of political competencies have raised questions about the raison d'être of local commoners' organisations. Commoners' organisations adapted to these changes, and preserved their existence by redefining their purposes and developing new functions. Bourgeoisies have developed new tasks, such as the preservation of heritage, in particular maintaining historical buildings; they also 
perpetuated traditions, including commoners' assemblies, religious feasts, and communal work. Bourgeoisies also act as a bond between commoners and their origins, in particular for those who live outside the valley, and contribute to defining the identity of commoners in a globalised world (Section 8.2). The case of common forests shows how bourgeoisies have adapted to an unfavourable economic context and decreasing public subsidies by merging their forest organisations into larger ones, and increasing revenue through market-based activities. In addition, they created an association of forest landowners on a cantonal level, which provides expertise and acts as an intermediary in the policy implementation process (Section 8.3). Consortages holding rights to pastures have maintained agricultural activity by transferring pasture management and use to single farmers. Despite the transformation of use, assemblies of right-holders persist. Their main function is the rental of the pasture, and the maintenance of infrastructure. Recently, new competition has emerged with nature protection and tourism policies, which threaten agricultural use (Section 8.4). The last section discusses the resilience of commoners' organisations in Anniviers. We describe the current limits of these organisations in adapting to policy and market changes.

\subsection{Historical development of existing organisations and institutions}

\section{From peasant associations to bourgeoisies}

The entire Val d'Anniviers formed a single community (communauté or généralité) ruled by the lords of Anniviers in the thirteenth century (de Gingins-laSarraz 1844). The family possessed a castle next to Vissoie, the central village of the valley, and held police, judicial, and chancellery fiefs transmitted by the bishop of Sion in exchange for monetary loans and other services. Franchises accompanied the fiefs, however, such as the right of inhabitants to choose local magistrates to administer justice, or the right to carry the valley's banner for military service. In 1380, the de Rarogne family came into possession of the fiefs of Anniviers through marriage. The increasing powers of the council of the districts in the Upper Valais, and Savoy's attempts to keep control over the Lower Valais, weakened absolutist claims held by noble families. In 1467, Walter Supersaxo, prince-bishop of Sion, recovered the fiefs from the deceased Hildebrand de Rarogne. While taking possession of the episcopal fiefs, the prelate asked male inhabitants to take an oath to their new temporal and spiritual leader. The bishopric maintained annual fees from the community (redevances), and reserved the right to nominate the castellan (chattelain). The castellan administered justice and presided over the valley's assembly on behalf of the prince-bishop. The latter also kept his function as supreme judge. As a means of compensation, he confirmed existing franchises, and promised to never let the fiefs to a feudal lord again. He also granted the community the power to elect the usher/local bailif (sautier). From 1547, a convention 
between the valley's quarters (Vissoie, Ayer, Grimenth, and St-Luc) regulated the election of the castellan and the valley's delegates to the council of the districts (Archives cantonales du Valais 1946).

Until the French Revolution, the castellan, the procurators, and the usher were the main political representatives of the valley (Zufferey 1927, Tamini 1935). The valley's assembly took place in Vissoie, the centre of parochial and civic life. Procurators (procureurs) delegated by each village gathered as an assembly under supervision of the castellan to decide upon local rules regulating various uses, including those of pastures, water, and forests. As the links within villages prevailed over those within the entire valley, the castellan, who was a foreigner to the valley, delegated his powers to vice-castellans. In agreement with village procurators, vice-castellans presided over the local assembly of each village, and supervised the management of local accounts, as well as the enforcement of regulations. Each village of the valley elected a vice-castellan on a two-year basis. These frequent renewals allowed the sharing of power among all local families and clans, and for most notaries and other capable citizens to have the honour of performing the function. To avoid spending scarce money on costly trials, vice-castellans did their best to arbitrate between conflicting parties, and find an arrangement that would not involve higher authorities. Procurators were locally elected individuals in charge of fulfilling a set of tasks on behalf of the community, such as calling assemblies, and collecting payments from fines and sales. According to Ghika (1954), procurators at that time may have acted as an executive committee, and thus fulfilled broader administrative functions than in contemporary bourgeoisies or consortages. Finally, ushers acted as intermediaries between inhabitants and authorities. They diffused bishop ordinances and orders from the (vice-) castellans, and received claims and complaints to be transmitted to the (vice-) castellans. One usher acted for the entire valley, and village ushers acted within their respective communities. Documents attest that in certain cases, village ushers also convened village assemblies (Ghika 1954).

Initially, the village assemblies comprised heads of households, and clans bringing together families of commoners. They gathered in each village to take care of the granaries and cellars held in common for storing foods (Tamini 1935). In the fifteenth century, after the bishop allowed the election of vicecastellans, and transferred rights over pasturable land to the villages, local assemblies gained new competencies. Not only did they regulate rights and obligations of their members from then on, they also protected commoners from outsiders, for example by preventing the sale of rights to foreigners, or offering protection from the feudal lords and the bishop (Kämpfen 1965: 154). These local assemblies of villages were in charge of regulating the membership of individuals to the community, define the rights of establishment, and voting and electoral rights. Villages could therefore progressively free themselves from the control exercised by feudal lords and the bishop, and establish bourgeoisies as local authorities. Based on the valley's former political sub-divisions, the bourgeoisies of Vissoie, Ayer, Grimentz, and Saint-Luc built their civic halls for 
village assemblies between 1571 and 1600 (Tamini 1935). At that time, most bourgeoisies and consortages did not have written statutes. A decisive factor supporting the codification of local rules was the adoption of the Statutes of Valais (Landrecht) in 1571 (Ghika 1954). After decades of negotiation, the bishopric and the council of the districts adopted the first statutes codifying customary law in Valais, including civil, judicial, penal, mortgage, and heritage law. They reserved the rights, franchises, freedoms, and immunities of the districts and other communities. The adoption of the statutes initiated a vast codification process of customs and practices within local communities, which used the occasion to assert their rights, police management, and the use of natural resources, such as pastures and forests.

In Anniviers, there are statutes from that time for the consortage (commune) of Zinal (Mariétan 1953, Ghika 1954). Zinal is located in one of the valley's bottoms. Although its lands are located in the territory of Ayer's bourgeoisie, rights on land were owned by people inhabiting various villages in Anniviers. Written in 1571, the statutes regulate the management and use of common and private rights on pastures, meadows, and real estate (chapel, school, paths, lime stone, and vineyards) in the mayens of Zinal, one of the two valley bottoms of Anniviers. The mayens were occupied only for short periods of the year: early spring and late autumn for the cattle to graze, a few days in summer to mow the meadows, and one month around new year to feed the cattle with the hay from the summer. Over 100 households from the entire valley held rights in the consortage. Widows and young women were admitted as members. Membership required the private possession of 1800 meters of meadows, and membership of one of Anniviers' village assemblies. Households acquired membership through inheritance, or by sale/acquisition approved by the assembly. Procurators called the commoners assembly, controlled the cutting of wood, and held the accounts. Guards controlled the ownership of the cattle pasturing within the consortage boundaries. Participation in the assembly, as well as one day of chores each year, were mandatory for all commoners. Fines were applied for absence or late participation in both. When gathering as an assembly, commoners admitted new members, and defined bans on the common use of private meadows. During a few days in spring and autumn, commoners opened their private meadows to all members for pasture and fertilisation by cattle. Such customary practices applied to all meadows in the valley, notwithstanding the owner of the meadow. They were the source of costly judicial conflicts, but were maintained nevertheless. The general rule determining the number of cattle each commoner could send to common pastures and meadows was the number of cattle they could raise during winter. For three days of wintering cattle, a commoner could send their cattle to graze one day in spring, one day in the summer, and one day in autumn. Further, regulations imposed a penalty for cattle driven down from Alpine pastures early. Rivalries with the foreign right-holders of Zinal's neighbouring Alpine pastures (Ar Pitteta, Singlina, Cottier) led to the prohibition of commoners working for both communities. Forest management followed 
strict principles. Statutes prohibited the export of forest litter and wood outside the community, and restricted the wood-consuming production of lime. Cut trees left behind by a commoner could be seized by any commoner one year and six weeks after the cutting occurred. It is unclear if the community held a monopoly on wood sales; however, documents attest that the consortage held wood rights in neighbouring jurisdictions, such as Alpine pastures, and the village assembly of Ayer, which shows the tight interconnections of these organisations.

These interconnections were also reflected in the nomad habits of the valley's inhabitants. Historically, the spatial fragmentation of cultivated areas between various locations and heights explained the transmigration patterns of Anniviers' inhabitants according to the seasonal calendar (Crettaz 1979). These transmigration patterns are believed to have existed for centuries. In addition to the transhumant migration between village and alpine pastures, typical of the Alpine economy, Anniviers' inhabitants took a specific hold in the Rhône valley. Rotating guardsmen excepted, entire villages migrated in early spring to the sunny northern slopes of the Rhône valley, where they tilled the earth of the vineyards they possessed in common. Houses with a stone basement used as a cellar, called mazots, hosted families and cattle up to Easter, when they moved back to Anniviers for celebrations. The next steps in their work were to spread manure in the fields surrounding the villages, and sow grain (primarily rye) and potatoes. In May, some family members went back to the Rhône valley to take care of the vineyards and mow surrounding meadows. Those remaining in Anniviers brought livestock to the mayens below the forest, where families also possessed hayfields and simple huts. The latter were used for hay storage, and occasionally for housing. Around the middle of June, families sent the cattle to the alpine pastures for three months. Over the summer, the family mowed the meadows close to the villages, and later the hayfields surrounding the mayens. Few family members went down to the Rhône valley to take care of the vineyards. Towards the end of September, the cattle were brought down from the pastures, and the entire village gradually gathered again in the Rhône valley to begin the wine harvest. In November, once the grapes were pressed and fermented, the families took the wine back to their mountain village in Anniviers. They harvested potatoes, did the butchery, and cut wood for the winter. These migrations resulted in families acquiring, exchanging, inheriting, or obtaining through alliances, various rights in consortages and bourgeoisies of which they were not formal members (terriens). Belongings held in common were both within and outside the valley, as the vineyards and neighbourhoods of Sierre belonging to Anniviers' commoners show. To enjoy commoners' rights, such as rights to wood, plant litter, and sending cattle to the Alpine pastures in the first instance, individuals or families often bought membership in other commoners' organisations. As a consequence, they also did related chores, which was the preferred means of payment. As a result, richer families, those who had more work than they could handle themselves, could hold rights in up to ten different bourgeoisies (Archives cantonales du Valais 1946). 


\section{From bourgeoisies to municipalities}

From the Helvetic Republic in 1798 onwards, the liberal-radical political ideology of the French Revolution stood behind the principle of equality of citizens (Kämpfen 1965: 144f). As bourgeoisies excluded inhabitants who did not hold rights of political participation, they were deemed incompatible with the newly created municipal power. Unlike in other French-speaking cantons, there was no merging of bourgeoisies with municipalities in Valais. The cantonal legislator opted for a progressive and disputed transfer of competencies in favour of municipalities. The transfer started in 1827 with the creation of a charity office to support the poor in each municipality, which was financed by a tax paid by all inhabitants (Noirjean 1974). Later, the law on Education from 1849 and the Law on Communal Regime of 1851 transferred a large range of competencies to municipalities, such as organisation of school, police functions, keeping of the civil register, the construction and maintenance of buildings, roads, water pipes, and bridges, and fire prevention. Infrastructure dedicated to the fulfilment of these new municipal tasks, such as the town hall and the school building, remained in the ownership of bourgeoisies, but were now to be used by the municipality. Bourgeoisies also kept ownership of their forests, but had to supply wood for public construction and works, as well as for heating buildings hosting public functions (Kämpfen 1965: 170f). Bourgeoisies were also obliged to supply land for the construction of roads. The Canton defined the Rhône river and a share of Geneva lake as cantonal ownership, and smaller rivers as municipal ownership. Such definitions explicitly recognised pre-existing rights over water, such as those held by bourgeoisies and consortages (Schweizer 2018).

The equal rights of inhabitants to local political participation was the most disputed change. In Valais, this was the exclusive prerogative of commoners residing in the boundaries of the bourgeoisie. The cantonal Constitution of 1839 first allowed citizens from Valais who were not members of a bourgeoisie to take part to local affairs, however their number was not to exceed a quarter of the number of commoners. Otherwise, the latter could elect a separate executive committee exclusively in charge of bourgeoisie affairs. Commoners strongly objected to integrating 'foreigners' into bourgeoisies, and defined substantial financial, ownership, and social hurdles for their admission. 'Foreigners' included illegitimate children, foundlings, persons without citizenship, and permanent residents. They accounted on average for $5 \%$ of the cantonal population, and up to 20\% of inhabitants in certain municipalities (Papilloud 1992: 60). The Federal Act on Homelessness of 1850 marked a turning point in the bourgeoisies' power, as it intended to merge existing categories of citizens into one category, which was entitled to local political participation. Removing these categories of citizens required these 'foreigners' to be admitted as members of the local community. As bourgeoisies had competence to admit new citizens, two options were available: (1) separate bourgeoisies from municipalities and transform them into civil entities without legal competencies, (2) admit 
'foreigners' as new members of a bourgeoisie. After much turmoil reflecting the reluctance of bourgeoisies to share power over their assets, ${ }^{1}$ federal law obliged bourgeoisies to admit perpetual residents and heimatlose as new members in their community of residency, and removed any admission fees for illegitimate children and their descendants (Papilloud 1992: 59). Regular admissions remained costly nevertheless. Until recently, they were a source of financial revenue for bourgeoisies. In 2007, for example, Grimentz asked for a 15,000 Francs admission fee.

The competencies of bourgeoisies in Valais remained largely unchanged in the twentieth century. It was only towards the end of the century that the last core competency of admitting foreigners to membership and Swiss citizenship started to erode. In 1995, bourgeoisies lost the competency to sign the act of origin of commoners in favour of municipalities. This act involves a document that Swiss citizens use to declare their residency when moving to another municipality or canton. In 2001 bourgeoisies were obliged to submit applications for financial loans to the cantonal government for approval. From 2005 onwards, alienation, exchange, and the division of real estate had to be approved by the bourgeoisie's legislative committee, but no longer by the canton. The final changes to the rules of admission for new members were made in 2008. First, cantonal legislation capped admission fees, as their amount was considered an obstacle to the acquisition of Swiss citizenship, and encouraged candidates to apply for citizenship in bourgeoisies with lower fees. Even today, admission fees remain high. They are around 5,000 Francs in Anniviers' bourgeoisies. As one bourgeoisie representative puts it: 'At that price, you have to fall crazy in love and be financially well endowed to make such an effort' (Interview 2). Second, and more important, legislation transferred the task of awarding citizenship to the executive committee of municipalities. The consequence of such a transfer is the bourgeoisies' loss of political relevance.

Despite the bourgeoisies' loss of competencies, and a substantial decrease in the share of commoners in each municipality, the canton of Valais still employs a 'communal dualism' (Papilloud 2015): two communes, the municipality and the bourgeoisie, coexist a priori within the same geographic boundaries. Both are regulated by the cantonal law on communes. Bourgeoisies are also regulated by a specific law, which grants them a high degree of legal autonomy (Ruff 2018: 13ff). They are not taxable and do not have financial obligations towards the municipality. Also, cantonal law prohibits mandates from being held in both executive committees. In practice, however, the autonomy of the bourgeoisies is limited. Nine out of ten municipalities have a single legislative and executive committee for the municipality and the bourgeoisie (Grand 2015). In other words, bourgeoisie matters are handled by all elected representatives, and not solely by commoners. In Anniviers, three bourgeoisies held separate committees until the merging of municipalities in 2008: Saint-Jean, Grimentz, and SaintLuc. Saint-Jean always held a separate committee. Grimentz separated its bourgeoisie and municipal committees in 1953, after non-commoners joined forces to become part of municipal authorities (Crettaz 1982: 112). In Saint-Luc, the 
separation dates back to 1984, and it was due to the municipality's refusal to finance maintenance works for old water mills belonging to the bourgeoisie. The majority of representatives showed little interest in these mills, as they considered them a painful remembrance of past times of hard work and simple living.

\section{Revival of bourgeoisies initiated by the merging of municipalities}

In 1998, the municipalities of Anniviers launched discussions and studies about the potential of merging. The municipality's reasons for merging were to challenge elected positions, and overcome a lack of internal expertise (Zufferey \& Constantin 2000). Holding positions on municipal committees entailed an important workload. Elected officials also had numerous coordination meetings with Anniviers' municipalities on various matters, such as water treatment, tourism, rubbish collection, fire fighters, police, civil protection, nursery services, and child protection. The lack of fiscal expertise within municipal administrations led to substantial delays in taxation, and generalised part-time employment limited the availability and quality of municipal services for inhabitants. Despite fears about the marginalisation of smaller villages, there were strong similarities and close ties among them (Chauvie \& Gabbud 2005). Tourism was and is the primary source of employment in four out of six municipalities, and the construction sector relied upon the sale of secondary homes. Citizens voted on the merger of municipalities in 2006. Participation in the plebiscite exceeded $83 \%$. The valley's school in Vissoie, operating since the 1970s, is frequently mentioned in questions about the high acceptance rate of the fusion of municipalities.

For 35 years, the entire compulsory school has been in Vissoie. [...] So the young already knew each other in a different manner. At one point, they all started to go to school together. And then we did the fusion of municipalities.

(Representative of the bourgeoisie of Vissoie, 12 March 2018)

In addition to the acquaintance among citizens, the geographical unit of the valley reflects attitudes towards the outside world in the single term for inhabitants, the Anniviards:

For us, it was so natural to be named Anniviers. [...] When you are in Sierre, Sion, or Lausanne, and now asked where you are from, you say: 'I am from the Val d'Anniviers, I am Anniviard. [...] It has always been like this. No one said 'We will build a new identity with the new municipality'.

(Representative of the bourgeoisie of Vissoie, 12 March 2018)

Surprisingly, Anniviers' commoners did not perceive the common identity as equally applicable to their bourgeoisies. On the same date, the commoners 
from the six bourgeoisies also voted on their merging, as prescribed by law. With an $83 \%$ rejection, they clearly decided against it. Interviewed bourgeoisie members underlined the importance of identity and the preservation of their bourgeoisie-specific heritage when explaining the rejection. In the words of two representatives:

People needed to keep their identity to accept the fusion of municipalities. By refusing the fusion of bourgeoisies, we thought that we will keep our roots, our heritage. Here in the valley, people are very protective. There were lots of rivalries between villages, fights, family wars, and these things travelled through time, like our wine.

(Representative of the bourgeoisie of Grimentz, 30 January 2018)

The bourgeoisie, people really wanted to keep it, because it is the union of the villages from the old commune! And it is important that this thing remains!

(Representative of the bourgeoisie of Ayer, 12 March 2018)

The merging of municipalities led to the revocation of joint property uses. Bourgeoisie buildings formerly used by municipalities for official meetings, administration, and the delivery of public services, were no longer used for municipal purposes. Some bourgeoisies have limited use of the newly available infrastructure. They try to rent it for social events, or make it available to local groups, such as ski or hiking clubs. Two bourgeoisies that had formerly held assemblies as part of the former municipality had to reestablish a commoners' assembly. Rituals were created to account for the bourgeoisies' renewed existence: 'After [the merging], we had a wake-up call that the bourgeoisie existed. And this is when the annual assembly started, with the annual meal. Before, we did not do it' (Interview 4). This separate annual assembly accompanied by a meal is the main change in the bourgeoisies of Chandolin and Vissoie. As a consequence, 'Through the merging, the bourgeoisie gained some identity. Before, it was hidden within the municipality' (Interview 4). Ayer and Grimentz kept their annual assembly and related traditions. Overall, in terms of activities, the municipal merger had a limited impact. Bourgeoisies focus on the management of their wealth and the support of traditions and activities, as they did under the former municipality.

\section{Patrimonial activities and feasts as proof of identity}

Following their loss of competencies and the merging of municipalities, the bourgeoisies' main function has become the conservation of heritage. Bourgeoisies representatives perceive themselves as the maintainers of local 


\section{François-Xavier Viallon}

cultural heritage, and as part of the heritage. 'When you live in the village, even if you are not a commoner, the bourgeoisie is part of the heritage. The bourgeoisie is a very symbolic place in the village' (Interview 1). Their understanding of heritage conservation includes the preservation of historical buildings, and the perpetuation of local traditions and memory. Historical buildings owned by bourgeoisies may include (Table 8.2): the bourgeoisie hall (former town hall), a saw mill, a mill, a granary, and cellars in Anniviers and the Rhône valley. For now, the municipality recognises the heritage conservation work of bourgeoisies. Such recognition is reflected in the payment of an annual lump sum of 20,000 Francs to each of the valley's bourgeoisie. The payment also covers communal subsidies for forest protection (see Section 8.3). One bourgeoisie representative spontaneously underlined the importance of such municipal support: 'Without such compensation, the bourgeoisie would not feel obliged towards the municipality, and at the first difficulty they would encounter, they would disband' (Interview 2). Commoners are confident in the municipality's support: 'The municipality has an interest in having working local and sectoral associations, either through bourgeoisies, or through village organisations. Because everything that these public organisations manage is not the responsibility of the municipality itself (Interview 2).

The remainder of common management and uses involves local traditions, rituals, and habits specific to each bourgeoisie, such as annual assemblies, religious celebrations, communal work, and feasts. Nowadays, commoners in Anniviers generally hold their annual assembly (rogations) in January, in accordance with legal obligations on closing the accounts (Vouardoux 2012). The assembly takes place in the bourgeoisie hall, a large room filled with wooden tables, benches, and a stove. Typically, the walls are decorated with families' coats of arms, paintings of historic-cultural elements, and portraits of the bourgeoisies' celebrities. Seating arrangements follow strict rules. One table is reserved for the bourgeoisie's executive committee. A second table, called table of the dead (table des morts) is reserved for people who do not contribute to the community any more (e.g. former authorities, guests, and the elderly). A third table is dedicated to new entrants. The protocol followed by each assembly varies depending on the bourgeoisie. It may include a procession, a mass, prayers, and music by fife and drums. The day generally starts with a visit to the cellar, a welcome drink, and the measurement of the barrels' contents. Then follows the administrative part of assembly. Key elements include the admission of new entrants, and the presentation and approval of the annual report and accounts. The assembly offers lunch to the participants. As already acknowledged by Crettaz (1982: 159), annual assemblies are often occasions where people drink a lot. After the lunch break, each participant receives a bread called cressin or cassin, a reminder of the flour bourgeoisies used to keep for their own use. The rest of the day's food is then sold by auction, a means of ostentatious spending in favour of the community. Commoners still conduct auctions today. 
Weak commons management, strong identity 203

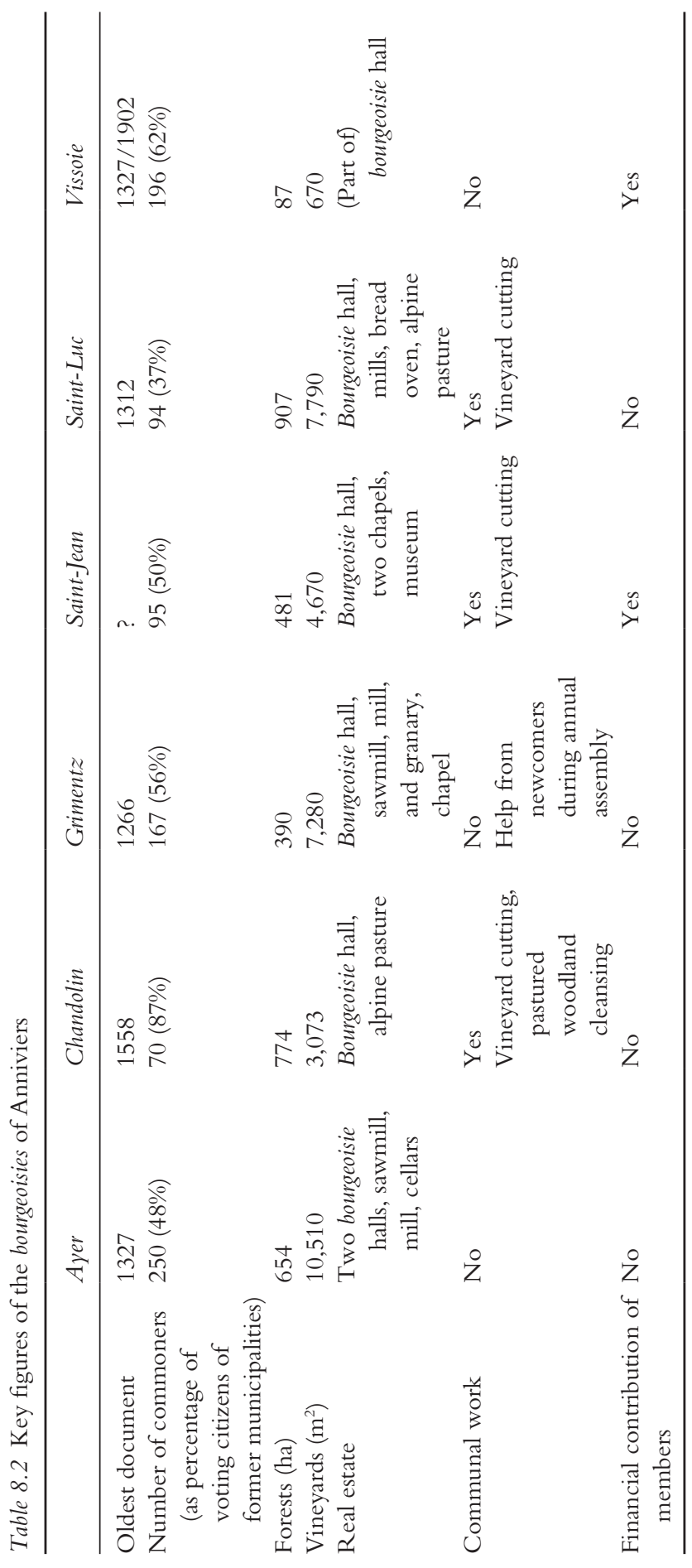




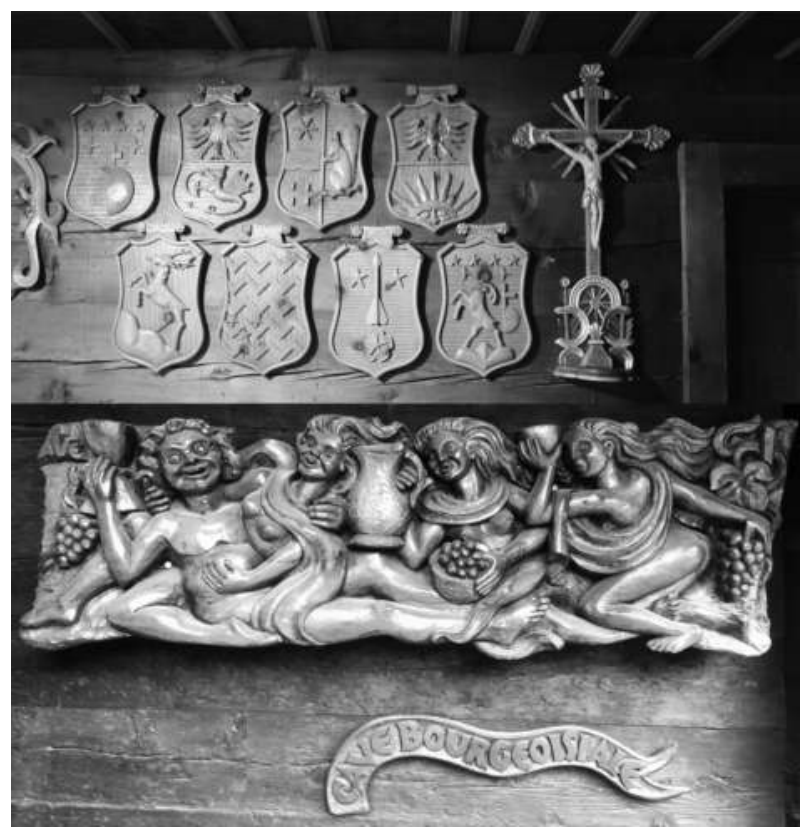

Figure 8.4 Detail coat of arms of families in the bourgeoisie hall of Grimentz; Detail - access to the cellar of the Bourgeoisie of Ayer. 2018. The author.

Such assemblies play an important role in the identity of their members. One commoner recalls a commoners' and municipal assembly in the 1950s:

Citizens who were not commoners had to wait until the end of the commoners' assembly to enter the room. So [in the room] were those who were already there and had talked. I recall that [the situation] bothered non-commoners a little bit. And I always felt that - legitimate, at least at that time - difference between native commoners, 'adopted' commoners, and non-commoners.

(Former representative of the municipality of Anniviers, 20 November 2018)

Nowadays, bourgeoisies no longer need to collaborate in carrying out communal work, and the question of identity appears to have taken the upper hand. Bourgeoisie assemblies bring together commoners who moved away from the bourgeoisie and live elsewhere in Switzerland or abroad. One interviewee defines these assemblies as 'the link between natives who stayed, or the newly admitted commoners, and those "from outside", who are pejoratively called "the diaspora". [...] They operate like a passport between commoners from the outside and those from the inside' (Interview 13). In other words, bourgeoisies bind 
individuals to their origins, they are embedded in people's need for identity. The same interviewee explains the contemporary attraction of bourgeoisies in light of Europeanisation and globalisation: 'This is not specific to Switzerland, today, we see it everywhere, in this big maelstrom ... everyone wants to be from a small place somewhere. [...] Lots of people agree with Europe, but they say: "nonetheless, we are from here" (Interview 13). Paradoxically, commoners from the inside are not always conscious of the connection that bourgeoisies create between insiders and outsiders, past and present, tradition and innovation. In the words of a commoner giving village tours to tourists: '[Tourists] are the ones who make us aware how important this history, this heritage, these persisting traditions are, and how important that is for future generations' (Interview 3).

Another highly symbolic activity of Anniviers' bourgeoisies is communal work. These obligations and functions have to be fulfilled by commoners, starting on the date of their entrance. Crettaz (1982: 114ff) distinguishes various types of functions that commoners may hold, and associated modes of elections: key-holders to the safe and the cellar are nominated for life, the sawyer and miller are 'public servants' whose jobs are tendered, the cellar master is nominated for a given amount of time, and temporary helpers designated for celebrations. In addition to these functions, commoners were responsible for specific tasks, such as collecting money and requiring services from commoners (procureur), taking care of the vineyard (métral), and supervising pastures and forests (garde-champêtre), the supervision of forests having been a responsibility of the municipality since the nineteenth century. They alternated among these tasks every two years, following a given order. Finally, all commoners spent days on communal work. They did these tasks in the forest, in the vineyards, and on the water channels. For many commoners, these tasks were one of the rare means of gaining some money. Nowadays, these tasks have been largely professionalised (e.g. forest and vineyards). In Ayer, the symbolic functions of procurer and servant remain; the former help with the annual assembly, the latter do an annual inventory of the cellar and tasting of the wines. Three bourgeoisies keep a day set apart for tasks in the vineyards in spring, following an ancestral ritual. The vineyard tasks of Saint-Luc's bourgeoisie include a large number of participants. 'Fifes and drums cross the village to wake people up, so they prepare for the vineyard tasks' (Interview 3). Between 30 and 40 persons gather to cut and fertilise vine stocks and erect pickets to hold the plants. Commoners refusing to serve their 'task day' have to pay a lump sum to the bourgeoisie. In Saint-Jean, the vineyard task relies on incentives: participation is voluntary, the bourgeoisie feeds and pays the commoners for their work. With the exception of this common day of work, the vineyards are managed by a professional producer, who may be a commoner. Crettaz (1982: 114) defined the tasks as the 'centrepiece' of historical bourgeoisies. Despite the abandonment of common vineyard tasks by three out of six bourgeoisies, the view that these tasks remain a centrepiece of commoners' organisations persists in the conception of commoners. 


\section{Cautious opening to women and non-commoners}

Gender equality has been an important subject in Anniviers' bourgeoisies for several decades. After the introduction of universal suffrage in Switzerland in 1971, women had the legal right to participate in bourgeoisie assemblies. In practice, their admission to assemblies did not happen smoothly everywhere. In Ayer, it took 24 years for commoners to hold a single assembly that included men and women (Epiney 2014). During that time, three assemblies were held: one for men on the traditional Monday, one for women the Sunday after, and a third "joint assembly for "legally binding" decisions, such as the adoption of the annual financial statements' (Epiney 2014: 30). Finally, in 1995, commoners voted on the merging of assemblies. They accepted this change with a majority of 2 votes out of over 100. Today, women's participation depends upon the bourgeoisie. When asked about recent changes among members of the bourgeoisie's executive committee, one representative answered: 'We have a woman in the committee, that's already plenty' (Interview 5). In the other bourgeoisies of Anniviers, women have regularly held seats in executive committees since the 1980s. Three were also the president of their bourgeoisie, a change that commoners did not expect to happen so quickly. In the words of a female representative: 'Bourgeoisies remain a men's world. [...] There are feminine representatives of bourgeoisies at the annual assembly of Valais' bourgeoisies, because municipal executive committees are in charge of most of the bourgeoisies. Otherwise, we are very, very few women' (Interview 1). Commoners may also experience closeness with the other sex when participating in rituals, such as annual assemblies. One female representative remembers: 'During my first year [in the executive committee], I felt very small at the annual assembly, at 9.30 in the cellar, because I was the only woman' (Interview 1). Indeed, the atmosphere of these assemblies might not encourage all commoners to participate. A former president describes the opening of annual assemblies as follows (Zuber 2014: 98):

The first meeting is at 7.30 in the bourgeoisie cellar. For me, it is out of question to breakfast with Fendant [wine]. I give instructions to procurers, servants, and the cellar master for the organisation of the day and the preparation of the assembly room. [...] At 8.00 o'clock sharp, we have to be in front of the church. The procession starts with, up front, the carrier of the cross, closely followed by the priest. Behind, it's the men's place, followed by the women.

The main bourgeoisie activities open to everyone are the aperitifs organised on various occasions. On a rotating basis, and in collaboration with the municipality, bourgeoisies prepare, for example, aperitifs for the newly admitted citizens. Such events echo their lost political competency of admitting new citizens. Other occasions for aperitifs are, for example, the patronal feast, Easter, Christmas, national day, or the drive from the pasture. Bourgeoisies may also organise activities and visits related to their property, such as guided tours of 
the village, bread making, wine tastings, and cellar visits. These activities are open to the public, but may require the payment of a participation fee. Their preparation occurs in close cooperation with the communal tourism office (Communal Tourism Office 2020), which relays the events on its website and integrates them with the weekly programme of activities for tourists. Such activities are in line with the bourgeoisies' move in the direction of tourism development (Crettaz 1982: 113). Grimentz, for example, organises gatherings and visits on several occasions.

'We organise an aperitif for mothers' day. We invite all mothers from the village, and also those who are here for the weekend. These meetings often take place after celebration, for example after the Saturday service. [...] We also organise a meeting day for the elderly. For them, it's an occasion to meet, and for our bourgeoisie, it is an opportunity to become known and to sell some wine. We want to promote our products.

(Representative of the bourgeoisie of Grimentz, 30 January 2018)

This section has analysed the development of bourgeoisies from their origins until today. From the fourteenth century onwards, village associations representing local families were established as local political actors. They granted rights, charged those inhabitants admitted to membership with duties, and protected them from higher authorities. At the same time, these associations also regulated natural resources that were key to the village economy, forests in particular. The legal codification of the associations' statutes, and their definition as bourgeoisies, took place in the sixteenth century. The bourgeoisies' statutes and rules remained largely unchanged until the Helvetic Republic. Following the changes brought about by the French Revolution, bourgeoisies attempted to keep their local position of power, and refused to open membership up to other inhabitants. As a consequence, they lost most of their political competencies in favour of municipalities, with the exception of the competency to admit candidates to citizenship. Despite the legal separation between bourgeoisies and municipalities, commoners in Anniviers, as in most municipalities of Valais, kept control over local affairs, as both organisations held joint assemblies at least until the 1960s. Reasons for the separation of assemblies included disagreements about the disposal of common goods. In the late 2000s, the competency of admitting inhabitants to citizenship was transferred to municipalities, and Anniviers' municipalities merged. As a consequence, bourgeoisies no longer held political functions. In their self-defined role as guardians of cultural heritage, bourgeoisies perpetuate annual assemblies, prepare religious feasts, and undertake communal work. They also create a bond between commoners and their origins, in particular those who migrated away from the valley. Bourgeoisies also engage in activities, some of which have been opened to the public, and even specifically target tourists. Here, the bourgeoisies' cellars and the unique wine production and curation traditions play a significant role. Putting forward the 
sensorial and symbolic values of these traditions, however, requires personal commitment to renew and conduct the activities of the bourgeoisies. As there continue to be stringent restrictions to membership and executive positions, for both non-members and women, these may hamper the appearance of new local personalities.

\subsection{Adaptations to changes in common forest management}

\section{Shrinking state support and increasing competition}

The canton of Valais has 90,000 out of 99,500 hectares of forests in public ownership (FSO 2019b), most of which are owned by bourgeoisies, and a minor share by consortages. The ownership structure is reflected in the administrative structures implementing forest policy. In accordance with federal forest policy, the cantonal office is responsible for collecting data on forests and defining political objectives, such as the preservation of forest functions and areas. Three forest districts (former inspectorates) provide counselling on forest exploitation and natural dangers, and approve the policy interventions of the canton's 34 forest consortia in their respective areas. Each forest consortium is an administrative level that decides upon policy interventions within the consortium's area - notwithstanding the ownership status of the forest, and, in the case of Anniviers, a public law organisation created by bourgeoisies managing their forest properties. Each consortium is bound to the canton by a three-year contract defining the methods and the area of intervention, as well as the amount of the subsidy paid for forest protection. Each consortium employs a forest ranger, who is responsible for a range of public duties. Since the creation of forest rangers in 1826, their primary public duties are to protect the forest against natural hazards, ensure river-shore maintenance, and promote forest conservation. At the same time, rangers also play the role of a manager. They are responsible for making a profit from forestry on behalf of the consortium and the forest owners. In recent decades, reducing state subsidies, decreasing wood prices, and high production costs compared to international competitors, have pushed forest consortia and the rangers towards complementary activities that fall outside forestry.

Until the middle of the twentieth century, forests and forestry products were key to Anniviers' inhabitants (Triage forestier 2020). Cattle holders sent goats and sheep to the woodlands for pasture. They also used forest litter in their barns when holding cattle. Wood served in constructions, such as planks and roofs, and inhabitants used it for heating. Other uses of wood typical of Anniviers were the production of stakes for vine plants, and planks for barrels. Both were made of larch, as the wood is resistant to decay, and provides a resinous taste to ageing wines. Inhabitants also used and sold larch resin as medicine, and pitch with which to pluck hairs when butchering pigs. Since World War Two, the decrease in wood prices, the liberalisation of the wood market, and the reduced 
importance of wood for construction and heating have modified the conditions of forest management and made forest consortia unprofitable (Steinlin 1975, Bisang 2000, 2001). These changes are also reflected in the 1985 revision of the cantonal law on forests, which followed a revision of federal forest policy. Authorities subsidised the management of protection forests, and pushed forest consortia towards concentration and professionalisation: the law prescribed the employment of full-time rangers, which resulted in the successive merging of small forestry consortia into larger ones. In counterpart, consortia were granted higher autonomy, as they were now responsible for nominating their own ranger, a former government prerogative. Legal changes in 2011 were aimed at increasing a consortia's financial autonomy: cantonal subsidies for forest protection were reduced from 11,000 Francs per hectare to 9200 Francs. As a means of compensation, the law defined a voluntary municipal subsidy as covering up to $10 \%$ of the costs of forest protection. In practice, municipal payments cover a cantonal average of $4 \%$ of forest protection costs. In 2009, the municipal contribution to the ranger's salary in Anniviers shrank from a third of the salary to approximately $5 \%$. In compensation, they pay a 20,000 Francs lump sum to each bourgeoisie. This lump sum is paid not solely for forests, however, but also for their heritage preservation, as well as the overall functioning of bourgeoisies (see Section 8.2).

Shrinking state support, but also shrinking revenue from forest management, have prompted forest consortia to carry out activities beyond their core business of forest management. The consortium in Anniviers developed a range of products and services that they offer to private and public buyers, such as the construction of poles, benches, fountains, tables, and fences, as well as trimmings, and maintenance around high voltage lines. The interviewed official from the cantonal office for forests sums up the growing importance of income outside forestry activities, and the generation of revenue through the market in a somewhat controversial statement: 'Today, the activities of a forest consortium in Valais are not primarily state-related. Rather, they consist of managing forest in the interest of its members, managing protective forests, and carrying out work for its members and for private entities' (Interview 7). In fact, the public tasks executed by the consortium reduced to a fraction of their activity. This change is reflected in the changes in the sources of revenue for Anniviers' forest consortium. Figure 8.4 shows the proportion of subsidies compared to the consortium's overall revenue. We observe a clear increase in the share of private revenue. Nevertheless, direct subsidies account for $30 \%$ of the consortium's revenue in 2018, and public contracts for an additional $22 \%$. These numbers put the public servant's statement into perspective. Further, we observe that municipal contracts have also reduced in terms of quantity. A bourgeoisie representative explains the changes as follows: "When the municipality of Anniviers was created, we tried to protect jobs and asked them for work. But now, there is no guarantee ... there are a lot of landscape contractors' (Interview 19). 
2008

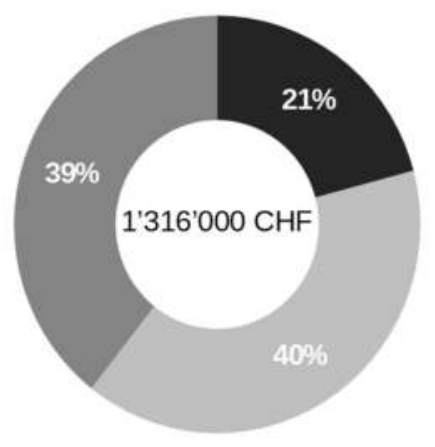

2018

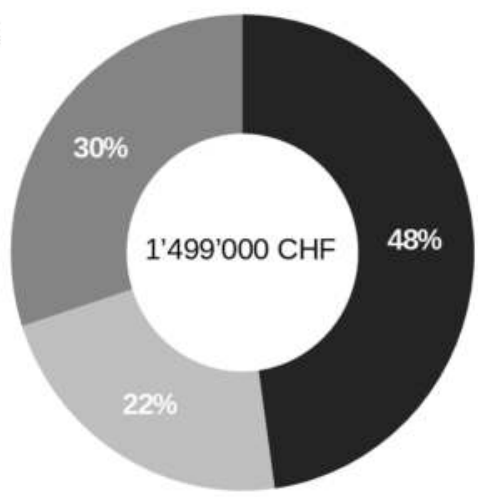

Public subsidies

Contracts with authorities

Contracts with third parties

Figure 8.5 Public and private revenue of Anniviers' forest consortium. The author.

\section{Institutional innovations in reaction to external changes}

Defining forest consortia does not stop at identifying their activities or their sources of revenue. Institutional aspects also play a key role. In the words of a representative of Anniviers' forest consortium, the consortium works like a company; however, the legal status and organisational structure of the 'company' are far from trivial. When creating the forestry consortium of Anniviers in 2004, the six bourgeoisies of Anniviers followed the recommendations of the canton's legal officers, and invested 300,000 Swiss Francs in the creation of a consortium of public law, a public law organisation co-owned by Anniviers' bourgeoisies. Each bourgeoisie's financial contribution was proportionate to the area of forest they owned, like the voting rights in the consortium's legislative committee. An interviewed official from the consortium explains the advantages of the organisation's legal status as follows:

The consortium is a public law organisation created by the bourgeoisies, which makes it easier to get procurement contracts. In fact, each time a bourgeoisie mandates forest works to the consortium, there may be bidding. With this system [the public law status], there is no procurement procedure between the bourgeoisie and the consortium. [...] It is also easier to work with the municipality.

(Representative of Anniviers' forest consortium, 7 November 2019)

When organisations of public law, such as bourgeoisies or municipalities, contract goods and services, they have to follow legislation on competition and 
procurement; however, this is not the case when executing public tasks, such as providing forest protection through a consortium. In this case, their 'administrative function' comes into play, and they can execute the task without procurement. In addition, the consortium is of public interest, and thus they directly benefit from public subsidies. As the consortium also privately contracts goods and services, they introduced a separation between the public and private tasks they execute. The separation can be seen in the book of accounts: 'We produce a separate account book for the maintenance of protection forests, to prove to the bourgeoisies and to the canton that we do not mix funds' (Interview 22). In fact, cantonal law obliges consortia to justify the spending of subsidies in a dedicated account book. Further, unspent or 'saved' subsidies are to be put in a specific account, the use of which is restricted to forest management and subject to cantonal approval. The other account book lists the revenue and expenses not related to the implementation of forest policy, such as goods and services sold to third parties. In other words, when contracting with the bourgeoisies owning the consortium, the latter acts on behalf of its members, and no procurement rules apply. When contracting with the municipality or private entities, the consortium follows public procurement rules and bids together with private companies for the offer. According to the ranger, competitors occasionally complain about the supposed competitive advantage of consortia due to their subsidised forestry activities. The consortium responds: 'We pay taxes like a private company, on water, on real estate, we also pay value-added tax' (Interview 22). The consortium's new activities do not reflect a conscious will to expand beyond their original function, rather, it reflects the struggle to survive within a changing environment. Facing shrinking subsidies for providing forest protection not only interferes with making a profit, but forces consortia to expand their activities beyond forest management in order to keep up with their public duties. As one interviewee puts it: 'If you cannot make a living in a given sector, then you try to make it somewhere else' (Interview 14).

\section{Granting forest subventions based on objective criteria}

Collecting information on forests is a central task of cantonal authorities. The canton uses such information to elaborate forest plans and determine priorities when subsidising forest protection. Available financial means being limited, authorities prioritise the quantity and location of forest areas to be taken care of each year. To do so, the canton establishes a forest plan for each consortium, which predefines the forest areas to be treated over the next 30 years. Defining forest areas rests upon a set of criteria valuing the importance of the forest in terms of its protective function. Relevant criteria include soil steepness, the proximity of access routes, villages, and other objects to be protected, as well as avalanche risks. Disagreements between consortia and authorities exist based on the consideration of local knowledge in the valuation of the forests' importance, as a representative of Anniviers' forest consortium says: 


\section{François-Xavier Viallon}

We provided information during the planning procedure, but the canton did not take it into account. They wanted neutral bureaus defining the areas in a mathematical manner. [...] We would have preferred forests that were easier to manage. This time, they really chose the most complicated forests to manage: on top of slopes, on top of roads, in dangerous places. It's true, we have complicated forests. Here, there is the cantonal road passing below, and it's always quite dangerous to work there in terms of safety.

(Representative of Anniviers' forest consortium, 7 November 2019)

Asked about the advantages of forest consortia over private contractors, the representative of the cantonal forest consortia association talked about the 'invisible services' provided by forest consortia that regular private companies contracted periodically could not provide:

[Consortia] have their own people in the area, they see the area change and can anticipate dangerous situations, because they know the area. They see, for example, if suddenly water accumulates in former irrigation channels of meadows that are now covered by forests. When these drains clog, they create wetlands that may come loose at some point. Only people who know the area can say: 'Oh! there is a dangerous change occurring. We can intervene before something happens.' If you contract somebody from outside, and always somebody different, you won't have the same knowledge and monitoring of the area.

(Representative of the cantonal forest association, 1 May 2019)

Further, the canton allocates an annual quota of surface to be treated by the consortium for each forest plan. Within the plan, the consortium is free to decide which areas to treat each year, as long as they match the quota and record it into the cantonal IT system. As a representative of the consortium says: 'It is our job to mix cuts costing a lot, and cuts costing less, so as to balance the accounts. We are kind of free to do as we want. [...] The system works well; it is rather easy administratively speaking' (Interview 22). The current allocation criteria might change, however. To reduce the forest's age and keep costs down, the cantonal proposition for 2020-2024 defines wood production as a new criterion for calculating the allowance. The aim is to reduce the age of forests to ensure better protection of people and the environment. The new criteria mean that maintaining the same allowance goes hand in hand with cutting more wood. Consortia and bourgeoisies in Valais strongly criticised the option, as 'Cutting more in these mountains means taking higher risks for the forest and for us, and this is not great' (Interview 22). According to the cantonal forest office, new policy directions are not to be discussed with forest owners. 
Forest planning is defined by the canton. It is the canton that sets priorities, and since funding comes from the Confederation and from the canton, the bourgeoisies do not choose which forest to treat. There is no ... this is not a negotiation.

(Cantonal servant, cantonal forest office of Valais, 18 September 2018)

Future legal changes also depend upon discussions in the Federal Parliament. The latter might modify the way of calculating subsidies and reintroduce an area-based method for the calculation of subsidies. The cantonal forest association of Valais pleads for a new approach: 'It would be fairer to say that forests offer protection services and that one pays for such protection' (Interview 14). In other words, prioritising the protection function would require compensation for the forest owners, as they do not have a responsibility per se to ensure protection of the infrastructure and inhabitants, and may prefer to cut more wood. A service-based approach would subsidise forest management notwithstanding the amount of wood cut, and take into consideration the difficulties of forest management (e.g. slopes, accessibility, etc.). A compromise with federal and cantonal authorities may be difficult to reach, as the cantonal and federal associations of forest owners consider themselves neglected during federal and cantonal legal consultation processes, and forest owners in the lowlands are more supportive of productionoriented policy goals.

\section{The cantonal forest association as a translator}

In Valais, the cantonal forest association founded in 1996 groups together all the forest consortia of the canton. It fulfils various tasks related to vocational and on-the-job training for the canton and Switzerland, such as quality assurance in training, and preparing and organising exams for forest vocational training. They also engage in public-relations-related activities, and hold meetings with scientists to foster knowledge exchange in the theory and practice of forest management. The association also plays an active role in translating existing norms into the beliefs and practices of consortium workers, as an example of the regulations on the transportation of dangerous goods shows. The association investigated the causes of a recent work accident involving a forest worker transporting gasoline to supply an engine operating in the forest. It turned out the worker had not carefully stowed the can of gasoline in the boot of their car. The association investigated the existing rules applying to the transport of dangerous goods, and found that the European Agreement concerning the International Carriage of Dangerous Goods by Road (ADR) prescribed a set of rules that the consortium workers were unaware of.

When you are transporting dangerous goods, the ADR or SDR apply, two big publications of 1000 pages each. And we never really bothered to 
pick out the few rules applying to our profession. There was no awareness of these rules.

(Representative of the cantonal forest association, 1 May 2019)

Subsequently, the association played an active role in gathering, translating, and disseminating the safety rules among its members. Their organisational capacity and position among the actors of forest management allowed them to gather the applicable rules, reformulate them in an easily comprehensible manner, and diffuse them within the entire profession to create learning effects. To ensure diffusion of the rules and application among forest workers, the association created specific reminder and training for the rangers, and adapted sector-wide safety standards accordingly. A representative of the association recalls:

We put a reminder on the transportation of dangerous goods on our website, and we also signalled it to our colleagues in other cantons; finally, [these changes] had repercussions in the sector-specific arrangements of the forest economy. The related safety concepts now include these [safety] measures, whereas they did not in the previous version. [...] We also offered specific training on the transportation and stowage of dangerous goods. There are a lot of rules to know.

(Representative of the cantonal forest association, 1 May 2019)

This example shows how the cantonal forest association may enhance the coordination of public policies. The association's actions allowed the existing 'siloisation' of forest and safety policies to be overcome, by 'translating' norms anchored in European agreements into the practices of local actors. This translation process took place via three means: (1) preparing information on existing regulations in written documents easily understandable by forestry actors; (2) diffusing these documents among them; and (3) providing adequate training for interested persons.

To conclude and summarise this section on forest management: for centuries, forest ownership in Anniviers remained in the hands of the bourgeoisies and of a few consortages without substantial changes to property. Each organisation managed their forest to primarily fulfil their own, similar needs. In recent decades, the reduced relative price of wood, the liberalisation of the wood market, and reduced public subsidies incentivised forest owners to join forces. In 2004, the six bourgeoisies created a single forest consortium in charge of managing their property in common. The consortium also signed contracts with consortages to exploit their forests on their behalf. These changes have led to a full professionalisation of forestry activities. Current uses have little in common with those from the past, in 
terms of both practices and products. The consortium still sells wood for heating, which commoners may acquire at a reduced price; however, the share acquired by commoners is marginal, compared to the total revenue of the consortium. An innovative product recently introduced by the consortium is wood chips. These chips allow for the transformation of cheap wood cuts into sustainable combustible heating. To support demand for this new product, the municipality recently changed the heating system of one of its indoor pools to a wood chip boiler. The exploitation of more valuable tree logs remains problematic, however, as production costs are high, and the region lacks transformers. As a consequence, the maintenance of the consortium's revenue and activities more and more depends upon alternative, private sources of income, as well as federal subsidies from forest policy. These subsidies are defined in multi-annual agreements between the canton and the consortium. These agreements set the area to be processed each year, as well as the forest maintenance criteria to be fulfilled to obtain the payments. The recently strengthened link between the quantity of cuts and the amount of subsidies goes against the interests of mountain forest owners, as they would rather cut only what is necessary to maintain the forest's protective function, preferably in areas where cuts may be processed for production. Further, in line with biodiversity subsidies, some of the cuts are left in the forest to allow for increasing biodiversity. As the interviewees said, such a lack of use was unimaginable 100 years ago.

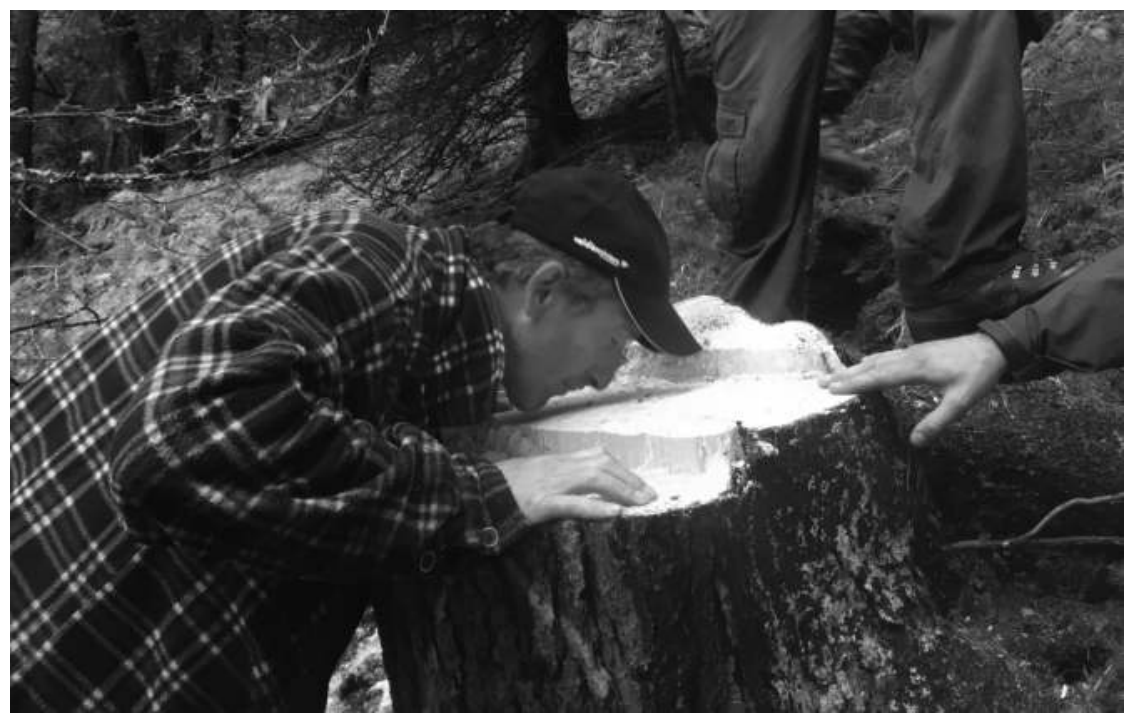

Figure 8.6 Commoner working for the forest consortium in Anniviers after a tree cut. 2018. The author. Jean-Yves Melly (person in the picture). 


\subsection{Adaptations to changes in agriculture and alpine pasture management}

\section{Visible and less visible land use changes}

In Anniviers, agricultural statistics report 618 hectares of productive areas, which corresponds to $1.7 \%$ of the canton's productive areas (Cantonal Agricultural Office 2020). Extensive grazing pastures (excluding Alpine pastures) cover 381 hectares, and meadows 238 hectares. The distribution of these pastures and meadows among 6,043 plots reveals a high fragmentation of landed property. Median plot size is $455 \mathrm{~m}^{2}$. As the former municipalities of Grimentz and Ayer made land readjustments, land plots are less fragmented in these areas, but the average farm size remains small. There are 41 farms in the municipality. Thirtythree farms have less than 10 hectares of land - the smallest has $1500 \mathrm{~m}^{2}$ of land distributed among 10 plots. Eight farms have between 15 and 126 hectares of land, distributed among 86 to 932 plots; these farmers also list agriculture as their primary occupation. In addition to these productive areas, the valley hosts 24 operating Alpine pastures totalling 6,970 hectares (see Table 8.4). Pasture sizes range from 2 to 1,424 hectares, located at between 1,700 and 2,800 meters in height. Seven (136 ha) are former hayfields surrounding mayens. These fields are located below the forest area, at heights of between 1,400 and 1,900 meters. They are owned by families who used the hay to feed their cattle during the winter. Following a reduction in mowing activities after World War Two, and the creation of community barns in the early seventies (see below), individual farmers took over the management of these areas. They send their own cattle, as well as cattle from the Rhône valley, prior to opening, and when the Alpine pastures are closed. Such intermediary uses have allowed the duration of summer pasture to be increased, and have thus liberated Anniviers' farms from cattle for longer periods of time.

A time comparison of the areas of each pasture is difficult, due to changes in agricultural statistics, as the pasture areas declared by farmers also include unproductive areas, such as scree. Nevertheless, when considering the total amount of pasture, we see an overall decrease of at least 840 hectares of pastured land (-11\%) between 1977 and 2019. Depending on calculations, this decrease in area may be twice as much, at 1660 hectares $(-22 \%)$. The land use cover statistics show a reduction of 408 hectares of grass and herb vegetation, of which at least a third have been substituted by tree vegetation (FSO 2019a). Forest growth has occurred primarily around the mayens, where the reduction of grazing areas is corollary to the sparsity of cattle. For reasons of size, several mayens struggle to attract enough animals to preserve the landscape. The less observable part of the phenomenon occurs at high altitude, where a reduction of pastured areas may not be accurately observable through statistics and aerial photographs. Rather, changes in terms of vegetation are linked to new agronomic practices, and are not directly reflected in cattle load. Since 1977, the average pasture load in Anniviers has increased by 29\%, and the average load is 98\% (see Table 8.3). One pasture, the commons of Grimentz, was abandoned; 
Table 8.3 Evolution of pasture load in Anniviers

\begin{tabular}{llll}
\hline & 1977 & 2009 & 2019 \\
\hline Total number of livestock units & 1,164 & 1,344 & 1,512 \\
$\begin{array}{l}\text { Average pasture load (as percentage of cantonal } \\
\text { reference values) }\end{array}$ & $76 \%$ & $87 \%$ & $98 \%$ \\
\hline
\end{tabular}

Source: Cantonal Agricultural Office (2020), Federal Agricultural Office (1977). For purposes of comparison, mayens designated as pastures since 1977 are not taken into consideration. The mayens, however, are precisely those areas most subject to loss of use.

two pastures abandoned in the 1970 s are grazed again today. In comparison to the average cantonal pasture load of $77 \%$ (Interview 21), Anniviers is well positioned. Almost all the valley's cattle grazes on its pastures. They account for a quarter of all cattle grazing on Anniviers' pastures. Pastures import the remaining livestock from farms located in the Upper Valais and in the lowlands. In 2019 some 900 cows, 1,300 heifers and calves, and 1,400 sheep grazed Anniviers' pastures. Factors explaining the relatively high load of pastures relate to the preservation of local farming activities, the professionalisation of pasture use, and investments in production infrastructure. The following sections explain these factors in greater detail.

\section{Common barns for maintaining local agricultural production}

With the decline of agricultural activities and rural exodus starting in the 1950s, pastured and mowed areas diminished substantially in mountainous regions. Anniviers was no exception. Effects included a reduction of agricultural production, a massive increase in fallow grounds, and a decline in landscape maintenance. The initiation of ski-related tourism development in the early 1960s revealed connections between tourism, agricultural activities, and landscape. Landscape maintenance and the presence of animals around villages were deemed necessary to attract tourists. A former representative of Vissoie's municipality recalls:

Once, I had a visit from a State Minister. A visionary. [...] I showed him around, and at some point, he said: 'All these meadows, they are not mowed'. I answered: 'Of course not, people do not want to mow them anymore.' And he said: 'And you want to do tourism without mowing the meadows? Are you crazy?'

(Former representative of the municipality of Anniviers, 20 November 2018)

In 1961, a prominent local developer, together with a farmer from Grimentz, formulated the idea of common barns to fight against the decline of agricultural 
use in the valley, allow for landscape conservation, and foster tourism development. Common barns aim to invigorate agricultural activity by granting people working in other economic sectors the ability to hold cattle as a secondary occupation or hobby. The goal of common barns is to economise on infrastructure costs and rationalise the care of livestock. They also allow reductions in the costs of acquiring straw and concentrated diets, inseminating cows, as well as acquiring and maintaining machinery used in common, such as a milking machine, manure evacuation system, or hay storage. Following the historical principles of a consortage, common barns issue rights that allow buyers to invest in the entity's capital, participate in the association's costs and gains, and raise private cattle in proportion to the number of rights they hold. Becoming a member requires possession of a title, and acceptance by the right-holder's assembly. The sale and lease of rights may be subject to preemption. For example, the common barn of Grimentz grants a pre-emption right on the sale of, and of rights to, the right-holder's assembly, individual right-holders, and inhabitants from Grimentz. Common barns host about 20 cows each, plus heifers and calves. Right-holders hire a manager to operate the barn from September to June. During the summer, a cowherd brings the cattle to their pasture. Depending on the barn, right-holders provide food for their cattle individually, either by providing areas to be mowed, or by buying additional hay. Food storage may be organised individually, or in a barn held in common. Other operational rules and tasks are subject to non-statutory agreements among right-holders. For example, right-holders may remove manure in proportion to the amount of livestock they hold, or delegate the task to the member with the most adequate skills to do so.

By increasing the amount of cattle bred and fed in the valley, common barns succeeded in relaunching mowing and pasturing activities (Federal Agricultural Office 1977, Zufferey 1991). The area exploited increased concomitantly with the opening of the barns, and restored maintenance of the landscape ecosystem. Common barns also showed that agriculture had a future in mountainous regions. It enabled local cattle breeds to be saved, and preserved traditional values and ways of living. A central reason for the success of common barns was and is the interest of individuals in keeping one or a few cows as a hobby. A substantial share of these individuals are known as 'horn lovers'. They raise cows from the local breed Hérens and use them for exchange and combat. The folkloristic and entertainment-related aspects of cattle are highly valuable for these hobby breeders. Exchanging cattle with other owners, drives to and from the pastures, as well as tournaments, are the primary motivation for their hobby; milk production and the financial aspects play only a secondary role, as these owners may not inseminate their cows to strengthen them for combat. The impact of hobby breeding is generally positive for local professional farmers. It contributes to filling common barns. It may also increase farming revenue, as they sell their best fighters to horn lovers. The latter also rent places in barns for raising them. Further, and more broadly, common barns contribute to preserving a link between inhabitants and agriculture, as they increase the 
number of people involved in agriculture, allow people to share their passion for animals, and supply local products to inhabitants and tourists. There are six common barns left today, as one assembly sold their barn to a professional farmer and disbanded. The professional farmer raising cattle in the barn of Saint-Jean illustrates the growing professionalisation of agricultural activities (see also Table 8.5).

\section{Professional management and residual common ownership}

The shift towards professionalisation in barns is also reflected in pasture management and use. Table 8.4 shows the areas, types of right-holder, and type of management in Anniviers' Alpine pastures. Pastures over 1000 hectares, such as Rouaz and Marais, result from the successive merging of smaller pastures into single farming units. Smaller pastures, such as Cottier, result from the disbanding of a former consortage, which sold their rights to a real estate developer. After the abandonment of the development project, the pasture was split into two, and the larger half transferred to a neighbouring pasture. In terms of ownership, the type of right-holders remained unchanged since 1977.

Table 8.4 Area, ownership, and management of Anniviers' Alpine pastures

\begin{tabular}{|c|c|c|c|c|}
\hline Pasture name & $\begin{array}{l}\text { Area } \\
\text { (ha) }\end{array}$ & Type of right-holder & $\begin{array}{l}\text { Type of } \\
\text { management } 1977\end{array}$ & $\begin{array}{l}\text { Type of } \\
\text { management } 2019\end{array}$ \\
\hline Ar Pittetta & 672 & Individual & Individual & Individual \\
\hline Barneusa & 182 & Consortage & Individual & Individual \\
\hline Cottier & 19 & Individual & None & Individual \\
\hline La Lée 1 & 819 & Consortage & Individual & Individual \\
\hline La Lée 2 & 98 & Consortage & Individual & Individual \\
\hline Lyrec & 267 & Consortage & Individual & Individual \\
\hline $\begin{array}{c}\text { Marais, Bendolla, } \\
\text { Tsougdires }\end{array}$ & 1165 & Consortage, Individual & Consortage & Individual \\
\hline Moiry 1 & 429 & Municipality & Consortage & Consortage \\
\hline Moiry 2 & 300 & Municipality & Consortage & Individual \\
\hline $\begin{array}{l}\text { Chandolin, } \\
\text { Ponchette }\end{array}$ & 221 & Bourgeoisie & Consortage & Individual \\
\hline Nava & 175 & Municipality & Individual & Consortage \\
\hline Orzival & 223 & Consortage & Bourgeoisie & Individual \\
\hline Rouaz & 1424 & $\begin{array}{l}\text { Bourgeoisie, Consortage, } \\
\text { Municipality }\end{array}$ & Consortage & Consortage \\
\hline Singlinaz & 327 & Consortage & Individual & Individual \\
\hline Sorebois & 251 & $\begin{array}{r}\text { Municipality, } \\
\text { Consortage }\end{array}$ & Individual & Individual \\
\hline Tracuit & 193 & Consortage & None & Individual \\
\hline Tsirouc & 68 & Consortage & Individual & Individual \\
\hline
\end{tabular}

Source: Cantonal Agricultural Office (2020), Federal Agricultural Office (1977). 
Consortages hold 60\% of Anniviers' pastures. Depending on the consortage, their members may be commoners from Anniviers, or from outside the valley. Such mixed ownership dates back to when the bishop of Sion granted rights of land to his vassals in the Rhône valley in return for their support in fighting the Dukes of Savoy (Julen 1978, Kämpfen \& Torrenté 2002). While sharing their pastures with 'foreigners', Anniviers' commoners had priority for summering their own cattle. The municipality holds rights on three pastures, corresponding to $15 \%$ of the valley's pasture. Two were bought prior to the construction of the Moiry water dam above Grimentz in 1954. The third (Nava) is the property of the former municipality of Ayer. The municipality probably bought the pasture after the consortage was disbanded, some time before 1940 . Bourgeoisies held rights primarily on two pastures, totalling $14 \%$ of the pasture area. The bourgeoisie of Chandolin owns the merged pastures of Chandolin and Ponchette, and the bourgeoisie of Saint-Luc, together with the municipality and individual owners, hold shares in the pasture of Rouaz. Such mixed ownership reflects public and common strategies to support pasture management. Individuals own the remaining $10 \%$ of pasture.

In terms of management, 9 out of 17 pastures had individual managers in 1977, and 2 pastures were not used any more. Today, 4 out of 20 pastures are managed collectively. One explanation for this change is the further reduced amount of cattle raised by right-holders. As a consequence, right-holders opted to rent the pasture to single farmers, who either brought their own cattle from the lowlands, or took care of a herd only for summering. Another explanation lies in the decreasing social function of agriculture, and at the same time its increased professionalisation. Table 8.5 shows the decreasing number of individuals raising cattle as a secondary occupation. It also shows that the overall amount of local cattle has barely been maintained over time. Local cattle are concentrated in the pastures of Moiry, Nava, Rouaz, and Tracuit, which are those under collective management and in possession of the municipality and/ or bourgeoisie. There is a statutory obligation for these pastures to prioritise cattle from the valley. The professionalisation of pasture management and use can also be explained by the human and financial costs of maintaining and renewing infrastructure, as well as difficulties filling positions within pasture

Table 8.5 Evolution of the number of farmers involved in agriculture and livestock units in Anniviers

\begin{tabular}{lccc}
\hline & 1977 & 1985 & 2019 \\
\hline Primary occupation & 15 & 10 & 8 \\
Secondary occupation & 183 & 154 & 33 \\
Livestock units of cattle & 486 & - & 382 \\
\hline
\end{tabular}

Source: Federal Agricultural Office (1977), Bugmann and Antille (1989), Cantonal Agricultural Office (2020). 
committees. The following paragraphs illustrate these changes using the pastures of Marais and La Lée as examples.

Located in the western part of the valley above the village of Grimentz, the pasture of Marais is owned by right-holders (allodiateurs) from Anniviers, and from the neighbouring Vallon de Réchy. Altogether they hold rights for 150 cow and 60 heifers. Summering lasts for 90 days, beginning 22 June and lasting until the middle of September. In 1977, the quantity of cattle had already diminished by 25\% since World War Two (Federal Agricultural Office 1977). In the early 1980s, the amount of cattle had reduced further, communal work was subject to the growing criticism of right-holders, and taxes and insurance costs had become a major source of spending. The current representative of the pasture recalls:

We did the days of communal work and everything: maintained the paths, the small ways, the water channels, it was work. At some point, we only had about 30 cows belonging to right-holders left. We said: 'We cannot continue like that.' We would have done the communal work for nothing. At the same time, we did not want to put an end to this pasture story, to this consortage, to everything. [...] We found a solution in letting it to someone, and got rid of the communal work. This is the story. At some point, people lost interest and said: we don't get anything out of it, why do we keep it? Let's clear it! But then we made a comeback. We found this [farmer]. In the end he helped us a lot. He was clever guy, he started to change the system.

(Representative of the consortage Le Marais, 17 September 2018)

Based on previous farming experience overseas, the new tenant adapted the functions of the pasture substantially. He abandoned the barns and the manure pit built after the war, and left the cattle brought from his farm in the lowlands on the pasture, day and night. He subdivided the pasture with fences and moved the cattle according to the season, and the amount of available grass. To allow for such a change, the assembly agreed to buy an old army truck to be transformed into a mobile milking walk-through station. They undertook landscaping work to create flat areas in several parts of the pasture, where the milking truck could be parked and used. As a consequence, the cows walked less, and manuring became superficial. The farmer also changed cow breeds. Traditional breeds, like Hérens, are very popular in Valais, as they have a combative temperament and play an important role in the local folklore, however, they produce about three times less milk than 'whites' (Prim'Holstein and others). Since the 2000s, the new tenant has obtained use rights on two neighbouring pastures, one held by a consortage, the other by an individual. The right-holders assembly of Marais paid for additional flat areas to be landscaped close to the neighbouring pastures, so as to make them accessible with the milking walk-through. Other recent 
improvements include covering these flat areas with concrete, and improving the access road, in collaboration with the municipality. The assembly also paid for the renovation and transformation of the old barn into a restaurant, which they rent to the ski-lift company every winter. In the summer, the farmer uses it to sell Alpine products. As a whole, the assembly reinvests all financial benefits from the pasture into the maintenance of infrastructure, and into stock from the ski-lift company. Further, the farmer pays rent to rightholders in kind.

When the right-holders summered their own cattle, regulations were numerous. The statutes and operating rules from 1937 totalled 74 articles. The statutes described the functions of procurators and other right-holders. The former prepared the pasture before and after summering, and provided food to pasture workers, as well as donkeys and bulls. The latter prepared and brought wood for cheese production, maintained paths and water channels. Operating rules defined the obligations of pasture personnel and salaries. The 2001 statutes total 20 articles regulating the functioning of the pasture assembly and committee. Today, Marais is one of the biggest and most successful pastures in Anniviers. As opposed to other pastures, its financial situation has been excellent since the creation of the Grimentz-Zinal ski-lift company. The latter pays rent for the four ski-tows crossing the pasture, and built a road to service the ski-tows, as well as pasture infrastructure. In addition, the municipality rents the use of a water reservoir during the winter, which was set up by the consortage.

Not all pastures have adapted in such a successful manner. La Lée is a pasture struggling to maintain agricultural activity. The pasture covers the western part of the valley bottom of Zinal, totalling an area of approximately 900 hectares. It divides into a lower part consisting of the former mayens of Zinal, which the right-holders assembly bought at the beginning of the twentieth century; the upper part primarily consists of steep mountain slopes below the Zinal glacier. Right-holders are primarily residents in Ayer and Zinal. They have rights for 144 cows and 60 heifers. As in Marais, the post-war period marked a significant decline in pasture activities. In 1964, the right-holders assembly registered 33 cows for summering. They judged the amount insufficient, compared to the rent to be paid by users, and to pasturing costs, such as the salary of employees, insurance for buildings, and social benefits, and therefore, the assembly decided to stop pasturing activities, and delegated the responsibility to find a tenant to the committee. Two right-holders took a lease; one summered sheep on the upper part, the other heifers in the lower part. The owners of registered cows sent their cattle to the Nava public pasture, which had been recently renovated by the municipality of Ayer. Consequently, from 1964 onwards, the common use of the pasture stopped, and pasture revenue and expenses reduced substantially. These changes were also reflected in the pasture statutes. Whereas the 1958 statutes dedicated most articles to questions of pasture use and related sanctions, the 2001 statutes essentially regulate membership, and define the functioning of the pasture assembly and committee. For example, the assembly kept a pre-emption right on any rights sold by its members, so as to prevent the 
rights being scattered and acquired by non-members. New regulations require a majority of three-quarters of the present members to disband the consortage, an option that was not specified in the old statutes. The new statutes also revoked sanctions against inadequate pasture use, inappropriate behaviour, and against absenteeism at the assembly.

Despite the end of common pasture use, right-holders decided to maintain the chore of pasture cleaning. In case of absence, including for age reasons, right-holders pay compensation to the assembly. Alternately, 12 right-holders gather to clean the pasture of rocks and wood, and to maintain historical buildings. The latter has become a key element of the consortage. Recently, with support from local authorities, the assembly decided to reconstruct a historical production site next to the former cheese cellar. These constructions act as a witness of past pastoral life. They are accompanied by informative panels explaining former pasture organisation. Members of the pasture committee give occasional guided tours to hikers and tourists. In the words of the pasture's representative: 'Back in the old days, there were additional chores, with physical responsibilities. Today, it has become more folkloric, but at the same time, we preserve traditions. There is a will to maintain certain things as they are' (Interview 20).

The adaptation of management rules further reflects on pasture constructions and other land uses. The assembly signed 30-year leases with interested right-holders to rent and renovate former pasture huts. Shepherds, members of the local hunting association, and other locals, use them occasionally for professional purposes and/or in their free time. In addition to side revenue for the consortage, these arrangements allow for the maintenance of a few historical constructions on the pasture. Another recent change is a nature compensation project carried out in the lower parts of the pasture. One of the valley's ski-lift companies had an obligation to compensate for the environmental impact of a newly constructed cable car. They negotiated an agreement with the consortage to do landscaping work on the pasture territory, and zone part of the area they manage as natural area. These works included the creation of a wetland, a crossing for pedestrians, a small lake, and an area for frogs. In return for accepting these works on their pasture, the committee negotiated discounts on rides from the ski-lift company for the next 30 years. Right-holders can buy ski passes at lower prices for themselves, their spouses and children, or receive a voucher for the ski resort restaurant. Interestingly, the agreement with the skilift company increased the demand for pasture rights among holders, as some intend to pass on a pasture right to each of their children. The pasture representative explains: 'Some parents wanted to buy a second right, because they had two children. [...] Now, we have a waiting list for right-holders interested in buying additional rights' (Interview 20). Despite ageing right-holders - most are over 50 years old - younger generations who inherited their right show enthusiasm about gathering as an assembly. According to the interviewee cited, the future of the pasture assembly is not a stake. Concerns are more about agricultural uses: 
The consortage will remain as a consortage of friendship, because people come to the day of communal work, they meet, often with their children, they enjoy it, and it motivates them to come again. These [habits] are fashionable, because there is a growing tendency to return to nature. We won't milk cows again, that's for sure, because there are fewer cattle. What I hope is that we keep livestock to maintain the cultural landscape. This is the big concern.

(Representative of the consortage of La Leee, 20

January 2020)

Indeed, agricultural activities on the pasture face substantial challenges. Over the past decade, the pasture has been under-loaded, to the point where the farmers may lose eligibility for agricultural subsidies. Further, the summer of 2019 turned out to be a tipping point in pasture use. A wolf attacked the sheep herd and wounded or killed 66 animals. Consequently, the tenant stopped summering activities and revoked the lease. As he was working part-time and towards the end of his career, the wolf attack pushed him to cease farming activities earlier than expected. According to a cantonal expert, the wolf acted as an accelerator, as 'the straw that broke the camel's back'. In La Leee, fortunately, the tenant from the lower part took over the lease temporarily, and arranged the summering of additional heifers with a young local farmer. Nevertheless, a further reduction of pasturing activities is highly probable, as additional cattle may not fully compensate for the flock of sheep. There are also fears that the wolf may attack the heifers. To protect the herd against predators, protection measures may be set up, as in the neighbouring Singlinaz pasture. There, a single tenant uses sheep dogs to protect his sheep herd against attacks of predators. The presence of the dogs also created new problems with tourism activities, however. During the summer, bikers using a dedicated mountain trail were advised to get off their bikes when riding along the pasture, a distance of 2.5 kilometres. More problematically, sheep dogs even attacked running trail users and scooters crossing the pasture on a designated path. Consequently, local and cantonal authorities are now under pressure to arbitrate between agriculture, nature protection, and tourism.

In summary, the cases of La Lée and Marais have shown several changes in terms of pasture use, which have had repercussions on management and ownership. The structural change of individual occupations, and the shrinking profitability of pasture use, induced a reduction in the number of livestock raised by right-holders, and an overall decline in agricultural production in mountainous areas. Consequently, the considered consortages have developed adaptation strategies. Right-holders asked professional non-members to provide the majority or entirety of the livestock summered on the pasture. In other words, they have become simple intermediaries between a single farmer and the pasture. Operational rules in the consortage statutes were simplified accordingly. Most right-holders do not have a direct connection with agriculture any more. In both cases, the main task of the pasture committee is 
the registration of rights. Other remaining traditional practices are the annual gathering as an assembly, holding an auction after the assembly, and the payment of the prémices. ${ }^{2}$ Social bonds and attachment to old habits play a key role in the preservation of the consortage. Right-holders have few obligations, if any. Rather, they derive side benefits from the touristic uses of pastures. Consortages and ski-lift companies have become 'connected vessels' which support each other, as well as the local economy. Right-holders contribute to a closed economic circuit, as they reinvest benefits from tourism into the ski-lift company. In terms of infrastructure, the case of La Lée shows how the substitution of cows by sheep and heifers has led to the abandonment of cheese production and buildings. The main investments in infrastructure were for heritage conservation purposes. Current pasture use is under threat from the combined pressure of predators and new tourism uses. In Marais, right-holders agreed to regular investments in infrastructure maintenance and expansion. They also seized opportunities for development, as the pasture restaurant and sales point show. Here, agricultural production and tourism have resulted in economically and ecologically viable outcomes.

Besides, it is worth mentioning that the municipality supported agricultural infrastructure and production with an average of 600,000 francs per year over the past ten years (Municipality of Anniviers 2019). This amount corresponds to $1.4 \%$ of communal expenses and investments, 'good support for agriculture', in the words of the municipal executive in charge. The most important projects supported by local authorities include renovated constructions and upgraded cheese production infrastructure in the two pastures they own. They also contributed financially to the construction of a new cheese factory possessed in common by the valley's farmers. The contribution consisted of the acquisition of the old factory's production site, and the provision of loans and securities for the construction of the new production site. They also subsidise milk production and the mowing of areas through additional direct payments. The municipality also owns a slaughterhouse rented to the valley's butchery, and intends to invest the necessary funds to upgrade it to legal standards. Further, state- and municipality-financed land-betterment programmes have been set up to limit the growth of bushes, facilitate mechanical hoeing, and preserve the landscape. Finally, the municipality has also invested in the renovation of former irrigation channels called bisses. These past and future investments target both the re-irrigation of agricultural land, and the creation of a tour of the valley's irrigation channels for hikers and pedestrians. When these works are complete, interested farmers may connect to the channel to irrigate their fields. New consortages may be created to share the water among interested parties.

To date, Anniviers' pastures have proved resilient to structural socio-economic changes and perpetuated pasture uses. Among the factors that contribute to the pastures' resilience, public investments, in combination with private tourism-based revenues, provide funds for modernising production infrastructure. As public investments target agricultural production in the entire valley, local farming activities persist, and the proportion of local cattle sent to pastures 
remains significant. Local cattle are a key element in maintaining the landscape ecosystem, as their fodder largely depends upon local hayfields, meadows, and pastures. Further, pasture resilience is conditioned to the professionalisation of pasture management and use. With the exception of the valley's three collectively managed pastures, which are strongly supported by public investments, pastures in Anniviers are under the management and/or use of professional individuals. Such professionalisation has the advantage of reducing the coordination costs associated with resource management and use (e.g. the definition and implementation of operational rules, monitoring tasks, sanctions, conflict resolution mechanisms). At the same time, it also reflects an increasing separation from local agriculture, and in particular from secondary occupations as a farmer. These non-professional uses have become marginal over the past decades, and overall local involvement with agriculture has reduced. As a consequence, agriculture may be increasingly isolated, and suffer from upcoming conflicts with other sectoral uses and policies. These policies may, for example, transform agriculture into a showcase that would primarily serve tourism purposes. This isolation of agriculture is also reflected in the ownership of consortages. The shrinking connection of right-holders with agriculture has not led to the disbanding of consortages for now. Although existing ownership rules have become unnecessary for pasture operation, commoners perpetuate old traditions and habits, such as gathering as an assembly, or collecting the pasture's produce. The distribution of cheeses among right-holders acts as a reminder of old times, when they collected the cheese produced by their own cows' milk. It also limits their sale as high-quality products on the market. In fact, most of the pasture produce in Anniviers is sold through direct or semi-direct delivery channels. As a consequence, relative prices remain low, and a substantial price difference between producer sale price (16 Francs per kilo) and buyer's market price in the supermarket (45 Francs per kilo) persists. Overall, the future of consortages is conditioned by the behaviour of inheriting right-holders. These may show less interest in gathering as an assembly and keeping up old traditions than current ageing participants.

\subsection{How resilient and sustainable are Anniviers' commoners' organisations?}

For centuries, commoners' organisations in Anniviers held rights on most of the valley's forests and pastures. Two types of commoners' organisations with distinct legal statuses and different types of rights on resources have persisted over time: consortages and bourgeoisies. Whereas consortages are associations of right-holders created for the purpose of managing a resource, bourgeoisies are former local authorities that shaped core elements of social and economic life. Bourgeoisies excluded non-commoners from political participation until their substitution by municipalities in the nineteenth century. Today, the access to bourgeoisies remains conditioned on local residency, and to the inheritance of a right to membership, or to its acquisition and to a vote of approval by 
commoners. The chapter analysed how the political power and economic relevance of commoners' organisations evolved over time, and adapted to changing relative prices and the increasing policy intervention of the nation-state from the second half of the twentieth century. We examined the cases of forests and pastures in Anniviers with the aim of expanding our understanding of contemporary Alpine commons. The management and use of these commons have a direct impact on two of the valley's contemporary challenges: the perpetuation of agricultural activities, and the maintenance of the landscape ecosystem. A better understanding of current resource management and use is important, as they have implications for the future of the commons and affect the state of the resources they manage.

The results of the study showed how relative price changes and the bargaining power of commoners' organisations in relation to the state impacted both their socio-political functions, and the management of the resources they possess. The ownership of Anniviers' forests went through few changes over time. Recent substantial changes occurred on the level of resource management. In the past decade, local bourgeoisies, which own most forests of the valley, created a joint consortium managing the bourgeoisies' and other private landowners' forests. Within the consortium, each bourgeoisie has voting rights proportionate to the areas of forest they own. This change of scale in forest management accompanied the growing requirements linked to forestry activities. The consortium's public competencies in forest protection management, and its status as a recipient of public subsidies, make it an indispensable local actor in forest policy implementation. In an attempt to adapt to shrinking state subsidies and increasingly competitive markets, Anniviers' consortium developed a range of private non-forest-related activities that provide an alternative source of revenue. This revenue now accounts for half the consortiums' income, and helps to mitigate reduced wood prices and the lack of competitiveness of Swiss mountain wood producers. This lack of competitiveness is further strengthened by recent modifications to criteria for the allocation of subsidies. Increasing incentives for wood production is a disadvantage for mountain forest managers, as they face higher productions costs and risks than producers in the lowlands.

The common ownership of pastures persists today. Contemporary and future difficulties arise from ageing right-holders and the shrinking ties of the younger right-holders with agriculture. A lack of interest in common ownership and agriculture in general may lead to the disbanding of consortages and the sale of pastures to individual buyers. In most cases, such a change of ownership would primarily reflect the changes in management and use that had already occurred several decades ago. However, consortages that do not have an updated register of right-holders may prove unable to adapt to changes, as right-holders or descendants of right-holders are unknown, and there may be unclaimed rights. As a consequence, the commoners' assembly may not make valid decisions, for example about selling the pasture. Considering pasture management and use, the rural exodus and the progressive withdrawal of hobby farmers from agricultural activities led to a professionalisation of Alpine pastures and agricultural 
activities. Most committees in Anniviers call in single farmers to run the pasture with livestock from outside the valley. Some pasture committees struggle to provide sufficient funding for renovating infrastructure, which in turn may lead to a decrease in production. Other pasture committees benefit from a geographic overlap with ski-lift infrastructure, and thus dispose of substantial revenue, allowing for the modernisation of production, and the preservation of agricultural activities. Recently, new challenges to pasture management and use have appeared. The growing importance of summer tourism, in connection with the protection of large predators, may be a threat to the preservation of agricultural activities, and in consequence to the landscape ecosystem as a whole. Arbitration among these rival uses may weaken agricultural uses further, as broad support for tourism could marginalise agricultural demands. Nevertheless, the threat should not be overestimated, as tourism itself depends upon the maintenance of pasture. Second, the redirection of policy subsidies towards area management, and the decrease in the minimum number of livestock units to be sent to pastures, may further challenge the use of Alpine pastures, and may result in changes in grass and herb vegetation, and the abandonment of smaller and/or less attractive pastures.

The chapter has traced the origins and changes undergone by bourgeoisies in their socio-political functions. Until the Helvetic Republic, bourgeoisies were organisations representing village families which progressively gained local autonomy from the prince-bishop. Their position changed in the nineteenth century, when they fought against liberal-radical ideas, introducing the free movement of people, citizenship, and the principle of equality. While the freshly created nation-state aimed to open local institutions to the participation of most inhabitants, bourgeoisies refused to integrate outsiders, and adopted inward-looking attitudes to escape what they perceived as a twist of fate. As a consequence, most of their political competencies were withdrawn and they became outsiders in the political game. In the words of one bourgeoisie representative from Anniviers:

Before [the nineteenth century], bourgeoisies were a central place of community and institutional life. Then, due to people's increasing mobility, this central place closed itself to natives, or to those making the effort to buy in. [...] Bourgeoisies did not adapt to keep their central position. They have exaggerated; they made a passage that was too narrow, so they were overrun.

(Representative of the bourgeoisie of Chandolin, 31 January 2018)

Until the 2000s, the sole political competency that remained in the hands of bourgeoisies was the highly symbolic task of admitting new citizens. Even in the absence of clear political function, bourgeoisies and commoners remained significant local political actors, as they held joint committees with their municipal counterparts. These joint committees elected commoners to keep control over 
both bourgeoisie and municipal affairs. In Anniviers, three bourgeoisies held joint committees with the municipality until 2008, and then, approval for the merging of municipalities, and the simultaneous rejection of the merging of bourgeoisies, disconnected these organisations, and separated the bourgeoisies from local politics. Instead, they renewed their role as village-based protectors of historical buildings, and custodians of traditions and other folkloric activities. The new municipality financially supports these works, as the maintenance of historical constructions and associated guided tours is a differentiating factor for tourism. In fact, tourism office representatives target cultivated middle-class tourists who are responsive to such promotion of local patrimony and culture. Further, bourgeoisies contribute to perpetuating local traditions and memory, and act as a bond between commoners, in particular those who moved away from the valley, and their origins. Annual assemblies, communal work, religious celebrations and other feasts provide an anchor to commoners who have left their place of origin, and remind them of their roots and history. These substantial functional changes were not reflected in their admission policy. Bourgeoisies remain a male-centred world, and strict admission rules combined with high fees block openings for non-commoners.

Together with the liberalisation of markets and the reorientation of state policies towards innovation and competitiveness, the mountain regions in Switzerland have been increasingly assessed regarding their capacity to contribute to national interests, such as energy production, tourism, and related landscape conservation issues (Rudaz \& Debarbieux 2013). In other words, the consideration of geographic, social, or economic specificities of mountain areas, as well as the associated specific financial support, tend to fade away. The described changes of criteria for the allocation of public subsidies to agricultural and forest policies clearly reflect this trend. To adapt to these changes, commoners' organisations have used local resources and knowledge to carry out new activities in the fields of forestry, landscaping, agricultural production, and tourism. By engaging in these activities, commoners' organisations contribute to mitigate change. These organisations are fragile, however, and their activities carry an intangible value that may be underestimated (Allaire 2019). At the same time, the specificities of mountain regions, compared to urban areas, have also reduced; the economic integration of Switzerland and Europe, particularly in the field of tourism and agriculture, has increased (Rudaz \& Debarbieux 2013). In addition, the arrival of new inhabitants has changed the social characteristics of mountain regions, and the increasing mobility of individuals has reduced the separation between urban and mountain areas as places to live. The integration of mountain regions in urban, national, and European markets and policies reflect their potential to benefit from private investments, as well as from the new regional policy, which targets the support of specific regional assets through the public and private subsidy of trans-sectoral innovative projects. It applies to all regions of Switzerland, and may act as a substitute for mountain-specific policy support. In Anniviers, projects under the new regional policy are under municipal leadership, and currently under review by cantonal authorities. The 
projects combine agriculture- and tourism-related activities, aiming to increase the combined promotion of touristic activities, agricultural production, and agricultural products. Planned measures include bringing the slaughterhouse up to standard, the promotion of local agricultural products, the development of agritourism, and the creation and improvement of hiking trails, including those next to irrigation channels to be restored by the municipality. These projects provide opportunities for the commoners' organisations to perpetuate, transform, or reinvent; it is up to them to seize those opportunities.

\section{Notes}

1 Some wealthy bourgeoisies divided and sold some of their goods to individuals prior to the integration of new members. Others signed conventions with poorer bourgeoisies to substitute for the admission of candidates to membership and citizenship (Papilloud 1992: 58f).

2 Traditionally, the prémices is a ceremony where each pasture assembly gives the cheeses made from the milk collected during the first day of pasture to the parish. Nowadays, assemblies in Marais and La Lée make a financial payment to the parish.

\section{References}

Allaire, G. (2019) 'L'ambivalence des communs', Développement durable et territoires. Économie, géographie, politique, droit, sociologie, vol 10, no 1.

Archives cantonales du Valais (1946) Armoirial Valaisan - Walliser Wappenbuch. Zurich: Orell Fuessli.

Bisang, K. (2000) Historisches Screening institutioneller Regime der Resource Wald (1870-2000). Lausanne: Institut des hautes études en administration publique.

Bisang, K. (2001) 'Historische Entwicklung der institutionellen Regime des Waldes zwischen 1870 und 2000' in Kissling-Näf, I., Knoepfel, P., and Varone, F. (eds.), Institutionelle Regime für natürliche Ressourcen: Boden, Wasser und Wald im Vergleich (pp 141-182). Basel: Helbing \& Lichtenhahn.

Blaufarb, R. (2016) The Great Demarcation: The French Revolution and the Invention of Modern Property. New York: Oxford University Press.

Bugmann, E. and Antille, N. (1989) 'Le modèle d'exploitation Vissoie/Saint-Luc. Cas particulier ou concept d'avenir pour l'exploitation agricole de montagne en Suisse?', Revue De Géographie Alpine, vol 77, no 4, pp 383-394.

Crettaz, B. (1979) Nomades et sédentaires: communautés et communes en procès dans le Val d'Anniviers. Genève: Grounauer.

Crettaz, B. (1982) Un Village Suisse. Le Temps, La Mémoire, La Mort et Les Dires de Robert Rouvinez, Paysan, Organiste et Conteur à Grimentz. Lausanne: Monographic, Editions d'en bas.

De Gingins-la-Sarraz, F. (1844) 'Développement de l'indépendence du Haut-Valais et conquête du Bas-Valais', Swiss Journal of History, vol 3, pp 109-158.

Ghika, G. (1954) 'Les statuts de la 'commune' de Zinal en 1571: à M. l'abbé Ignace Mariétan', Annales valaisannes, vol 9, no 3-4, pp 205-240.

Grand, A. (2015) 'Die Burgerschaften im Wallis - Les bourgeoisies en Valais' in Schweizer Bürgergemeinde - La bourgeoisie suisse - Il patriziato svizzero - La vischnanca burgaisa svizra (pp 51-56). 
Julen, T. (1978) Das Burgerrecht im Oberwallis: vom Mittelalter bis zur Französischen Revolution. Unknown Place: Unknown Publisher.

Kämpfen, W. (1965) 'Les bourgeoisies du Valais', Annales valaisannes : bulletin trimestriel de la Société d'histoire du Valais romand, vol 13, pp 129-176.

Kämpfen, W. and Torrenté, B. (2002) Essai sur l'évolution des communes bourgeoisiales valaisannes - Essay über die Entwicklung der Walliser Burgergemeinden. Unknown Place: Fédération des bourgeoisies valaisannes.

Mariétan, I. (1953) 'Le consortage de Zinal', Bulletin de la Murithienne, vol 70, pp 52-61.

Noirjean, F. (1974) 'Evolution des communes bourgeoise et municipale dans le Jura et en Valais au XIXe siècle' in Tschopp-Bessero, M.-P., Arlletaz, G., Joris, G., Papilloud, J.H., and Rey, P.-M. (eds.), Société et Culture du Valais contemporain (pp 175-184). Sion: Groupe valaisan de sciences humaines.

Papilloud, J.-H. (1992) 'Le Valais et les étrangers, XIXe-XXe' in Alettaz, G., Papilloud, J.-H., Evéquoz-Dayen, M., and Tschopp, M.-P. (eds.), Société et culture du Valais contemporain (pp 11-62). Sion: Groupe valaisan de sciences humaines.

Reynard, E. (1995) 'L'irrigation par les bisses en Valais: approche géographique', Annales Valaisannes, vol 70, pp 47-64.

Rudaz, G. and Debarbieux, B. (2013) La montagne suisse en politique. Lausanne: Presses polytechniques et universitaires romandes.

Ruff, F. (2018) Die Burgergemeinden des Kantons Wallis. Schulthess. Zurich: University of Zurich.

Schweizer, R. (2013) 'Accessibility, Equity and the Sharing of Water Resources. A Critical Analysis of Community Governance Models Based on a Case Study of the Irrigation Channels of the Valais', Journal of Alpine Research | Revue de Géographie Alpine, vol 101, no 3 .

Schweizer, R. (2014) Stratégies d'activation du droit dans les politiques environnementales - Cas autour des bisses valaisans. $\mathrm{PhD}$ Thesis. Lausanne: University of Lausanne.

Schweizer, R. (2018) 'Avoiding the Commons Trap: An Exploration of Local Community Governance of Water in Valais, Switzerland' in Bréthaut, C., and Schweizer, R. (eds.), A Critical Approach to International Water Management Trends: Policy and Practice (pp 23-44). London: Palgrave Macmillan UK.

Tamini, J.-E. (1935) 'La châtellenie épiscopale d'Anniviers de 1467 au nouveau régime 1798', Annales valaisannes : bulletin trimestriel de la Société d'histoire du Valais romand, vol 2, no 2, pp 365-376.

Zufferey, E. (1927) Le passé du Val d'Anniviers dans le cadre de l'histoire valaisanne: d'après les archives des communes et tous les renseignements accessibles : un exemple de la façon dont se sont formées les institutions locales. Ambilly-Annemasse: Soc. d'Imprimerie.

Zufferey, J.-J. (1991) Aspects économiques, socio-culturels et écologiques des exploitations agricoles de montagne dans le Valais central. Sankt Gallen: Hochschule Sankt Gallen.

\section{Other sources}

Cantonal Agricultural Office (2020) Farming Statistics. Châteauneuf: Département de l'économie et de la formation.

Chauvie, P. and Gabbud, B. (2005) Communes d'Anniviers. Dossier de fusion. Sion: Association suisse pour le service aux régions et communes SEREC.

Communal Tourism Office (2020) Overnight Stays Statistics. Anniviers: Municipality of Anniviers. 


\section{François-Xavier Viallon}

Epiney, L. (2014) 'Bourgeoisies et Traditions' in VA (ed.), Bourgeoisie d'Ayer (pp 28-32). Ayer: Bourgeoisie d'Ayer.

Federal Agricultural Office (1977) Cadastre de la production agricole. Bern: Département fédéral de l'économie publique.

Federal Planning Office (FPO) (2018) Built Area Statistics. Bern: Federal Department of the Environment, Transport, Energy Communications.

Federal Planning Office (FPO) (2020) Secondary Homes Statistics. Bern: Federal Department of the Environment, Transport, Energy Communications.

Federal Statistical Office (FSO) (2017) Structural Business Statistics. Neuchâtel: Federal Department of Home Affairs.

Federal Statistical Office (FSO) (2019a) Land-Use Cover Statistics. Neuchâtel: Federal Department of Home Affairs.

Federal Statistical Office (FSO) (2019b) Forest Statistics. Neuchâtel: Federal Department of Home Affairs.

Municipal Tourism Office (2020) Statistique des nuitées. Anniviers: Office du Tourisme du Val d'Anniviers.

Municipality of Anniviers (2019) Comptes 2008-2018. Anniviers: Commune d'Anniviers.

Office cantonal de la statistique et de la péréquation (OCSP) (2018) Historique de la population résidante. Sion: Administration cantonale des finances.

Papilloud, J.-H. (2015) 'Les Bourgeoisies Valaisannes' in Bourgeoisies indépendantes du Centre et du Bas-Valais (eds.), Les Bourgeoisies Valaisannes Entre Tradition et Innovation. Sion.

Steinlin, H., Schelbert, H. and Crettol, G. (1975) Gesamtkonzeption für eine schweizerische Wald- und Holzwirtschaftspolitik. Bern: Eidgenössisches Oberforstinspektorat.

Triage forestier (2020) Historique du triage d'Anniviers. Online: https://triage.anniviers .org/.

Vouardoux, A. (2012) Grimentz et sa Bourgeoisie. Anniviers: Bourgeoisie de Grimentz.

Zuber, G.-A. (2014) 'La journée des rogations sous l'oeil d'un ancien président' in Bourgeoisie d'Ayer (ed.), Bourgeoisie d'Ayer (pp 97-100). Ayer: Bourgeoisie d'Ayer.

Zufferey, J. and Constantin, F. (2000) Communes d'Anniviers. Commission Collaboration Fusion. Rapport Intermédiaire. Anniviers.

\section{Interviews}

Interview 1, 30 January 2018, representative of the bourgeoisie of Grimentz, Anniviers, 92 minutes.

Interview 2, 31 January 2018, representative of the bourgeoisie of Chandolin, Sierre, 147 minutes.

Interview 3, 1 February 2018, representatives of the bourgeoisie of Saint-Luc, Anniviers, 99 minutes.

Interview 4, 12 March 2018, representative of the bourgeoisie of Vissoie, Anniviers, 104 minutes.

Interview 5, 12 March 2018, representative of the bourgeoisie of Ayer, Anniviers, 101 minutes.

Interview 6, 17 September 2018, representative of the consortage Le Marais, Sierre, 107 minutes.

Interview 7, 18 September 2018, cantonal servant, cantonal forest office of Valais, Sion, 53 minutes. 
Interview 8, 12 September 2018, cantonal servant, cantonal agricultural office of Valais, Châteauneuf, 30 minutes.

Interview 11, 10 December 2018, former consultant to the municipality of Anniviers, Anniviers, 146 minutes.

Interview 12, 10 December 2018, representative of the bourgeoisie of Saint-Jean, Sierre, 86 minutes.

Interview 13, 20 November 2018, former representative of the municipality of Anniviers, Anniviers, 150 minutes.

Interview 14, 1 May 2019, representative of the cantonal forest association, Lausanne, 114 minutes.

Interview 16, 6 May 2019, representative of the municipality of Anniviers, Anniviers, 72 minutes.

Interview 17, 5 June 2019, farmer from Anniviers, Anniviers, 93 minutes.

Interview 19, 7 November 2019, representative of Anniviers' forest consortium, Lausanne, 66 minutes.

Interview 20, 20 January 2020, representative of the consortage of La Lée, Anniviers, 106 minutes.

Interview 21, 22 January 2020, cantonal servants and farmer, cantonal agricultural office of Valais, Châteauneuf, 98 minutes.

Interview 22, 13 June 2018, representatives of Anniviers' forest consortium, Anniviers, 367 minutes.

Interview 28, 20 January 2020, representative of Anniviers' tourism office, Anniviers, 100 minutes. 


\title{
9 A fragile balance? \\ The case of pasture and forest management in Olivone (Canton Ticino)
}

\author{
Mark Bertogliati
}

\subsection{Introduction}

Towards the middle of nineteenth century Carlo Cattaneo (1851) wrote that collective rights "are not abuses, they are not privileges, they are not usurpations: it is another way of owning, another legislation, another social order". This passage is one of the most cited in Italian historiography on the commons, although it refers to the Canton of Ticino and the particular context of the Plain of Magadino.

But what were these constraints, considered by economists of the eighteenth and nineteenth centuries to be the worst enemies of private property? This case study focuses on a local corporation from the upper Blenio Valley in the Canton of Ticino, on the southern slopes of the Swiss Alps. We will see to what extent, with what outcomes and adaptations, the forms of management of collective forest and pasture resources - and the respective institutions that manage them - have survived to the present day under conditions of structural change involving the devaluation of agrarian and timber products and state control via subsidies. The case study involves a commoners' organisation that faces great challenges regarding the balance between market and state, as well as its fragility in the Italian-speaking part of Switzerland, which in many ways can be considered "a laboratory in a laboratory".

\section{Study area}

The area of the Patriziato generale of Olivone, Campo and Largario (PG-OCL) covers $82 \mathrm{~km}^{2}$ in the upper Blenio Valley, with an altitude ranging between 900 and $3000 \mathrm{~m}$ above sea level. Looking north-west it extends from the village of Olivone to the border with the Canton of Grisons (Lukmanier Pass), and to the north-east it reaches the area of Soprasosto and Campo Blenio, with an offshoot towards the east in the lateral valleys of the Luzzone and Carassina (Figure 9.1). Properties in the PG-OCL consist largely of pasture $(40 \%)$, forest $(38 \%)$, rocks and unproductive land (21\%) and, to a small extent of $1 \%$, buildings and settlements (Figure 9.2). ${ }^{1}$ The territory alternates between wildlands, limited settlement areas and large sectors in which different public 


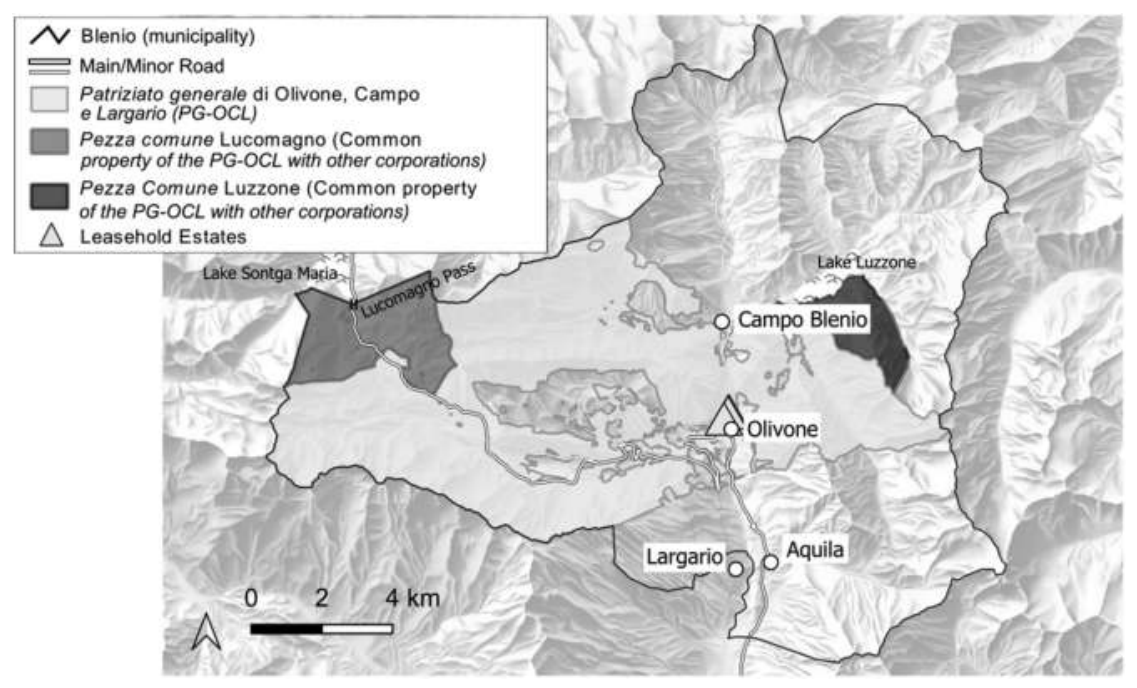

Figure 9.1 Landed property of the PG-OCL corporation - overview. Map compilation and design by Sarah Baumgartner, University of Bern. Geodata source: (C) Misurazione ufficiale del Cantone Ticino, 2018; hillshade: Relief PK 50, reproduced with permission of swisstopo (BA20043).

interests overlap, ranging from protection against natural hazards to tourism and landscape conservation and biodiversity. The extent of the land seems to justify extensive management and common property organisation, a solution that is widespread in the Alps as indicated by scholars such as Netting (1976: 140), Merzario (1989: $19 \mathrm{ff}$ ) and Ostrom (1990: 63), but, before their work, also by local authors (Bolla 1935: 16). Another characteristic of land ownership in the PG-OCL is that of being inserted in "a delicate territory with a high potential for conflicts between alpiculture, forestry, environmental protection and tourism" where "pastures, alps, forests and unproductive land are closely interconnected and form, as a whole, the typical mosaic landscape of the Central-Alpine mountains" (Bruni 2000: 7).

The summering rights of the PG-OCL also extend into areas in which several corporations still hold user rights in common. This is the case, for example, for the "Pezza comune del Lucomagno", located between Acquacalda and the ancient hospice of Santa Maria on the border with the Canton of Grisons. In this area the PG-OCL shares summering rights with the Patriziati of Marolta, Castro and Leontica (Vicari 1985: 22). Another pezza comune ("common patches", literally translated), shared with the Patriziato generale of Aquila, Torre and Lottigna, as well as the small Patriziato of Ghirone, is located between the Luzzone and the Carassina valleys. These entities of "mixed uses" are a legacy of the alpine expansion that has taken place since at least the Middle Ages, when the different communities of the valley tried to extend their mountain pasture rights (Bolla 1935: 37-43; Deplazes 1981: 120-124). These hybrid 


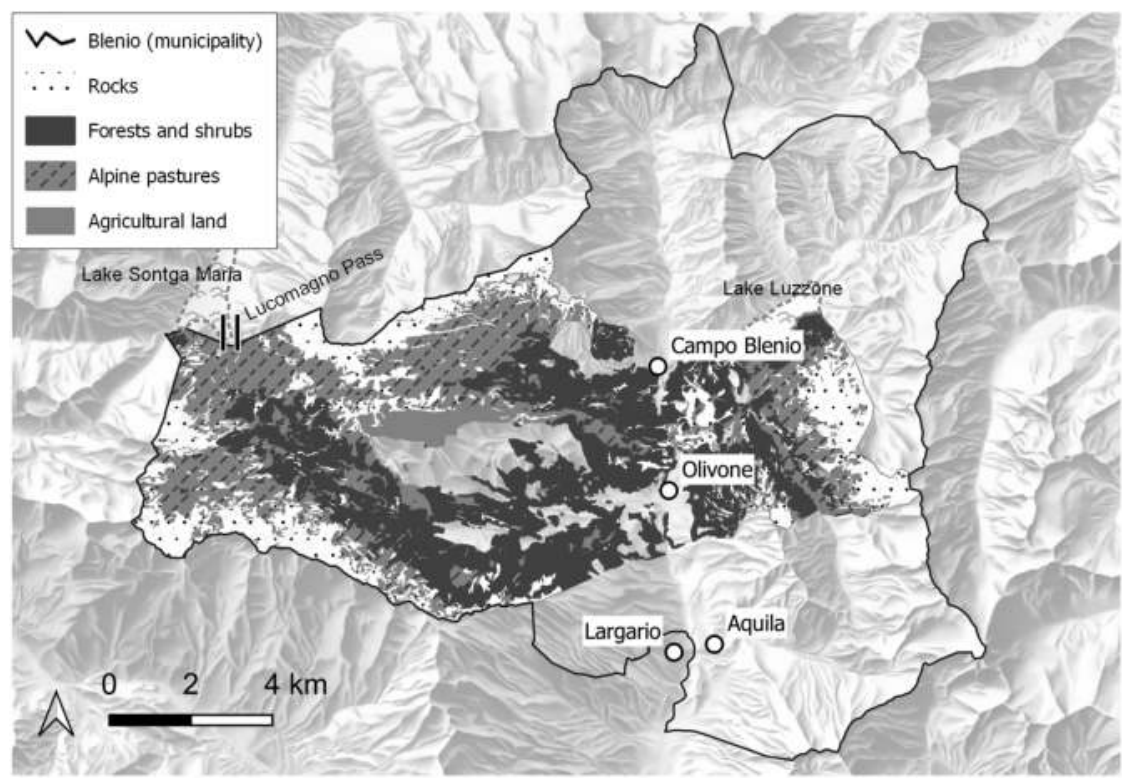

Figure 9.2 Landed property of the PG-OCL corporation - land cover and use. Map compilation and design by Sarah Baumgartner, University of Bern. Geodata sources: (C) Misurazione Ufficiale del Cantone Ticino, 2018; Land Cover: swissTLM3D land cover, reproduced with permission of swisstopo (BA20043); hillshade: Relief PK 50, reproduced with permission of swisstopo (BA20043).

situations of co-ownership between different commoners' organisations, still present today, are important for understanding the interactions between different corporations and different methods of governing the commons. Many conflicts arose from the use of this kind of - often very vast - land organisation. Such controversies lasted centuries and have continued until the present day. Disputes between communities and corporations are important processes for institutions: they are useful means of affirming use rights and formalising land management practices. Many disputes in the Lukmanier area revolve around summering rights on the pezza comune, due to its strategic importance and size.

There are two other alps owned by the PG-OCL adjacent to the big alps of Valle di Campo and Lukmanier: the Alpe Bolla in Val Carassina and the socalled "sheep alp" (Töira and Saltarescio ${ }^{2}$ ), both rented to private farmers. The PG-OCL is included in the jurisdiction of the political municipality of Blenio, founded in 2006 from the merging of municipalities in the upper part of the Blenio valley. The Town Hall is still based in Olivone and the three entities that make up the PG-OCL (Olivone, Campo Blenio and Largario) were separate political municipalities before the merging, although they had already been united for centuries in the administration of commons. ${ }^{3}$ Tables 9.1, 9.2 and 9.3 
Table 9.1 Key data of the political community of Blenio (2019)

\begin{tabular}{ll}
\hline Area (km2) & 202 \\
Population (inhabitants) & 1,826 \\
Population density (inhabitants/km2) & 9.04 \\
People employed & 590 \\
\hline
\end{tabular}

Source: Ufficio cantonale di statistica, Bellinzona.

Table 9.2 Key data of the PG-OCL

Oldest document (oldest mention of the corporation)

Number of commoners (resident in the community), 2017

Number of families of the corporation (resident in the community), 2017

Number of commoners related to total population (2005)

Total ownership (2020)

Forest area (2020)

Agricultural land (2020)

Properties
$965(1136)$

772

$388(170)$

1 house, several "rustici", industrial/artisanal area "Giaira", camping-area, parking and info centre "Lucomagno".

Source: Dipartimento delle Istituzioni Cantone Ticino.

Table 9.3 Financial situation of the PG-OCL in 2005

\begin{tabular}{lcr}
\hline & $\%$ & $C H F$ \\
\hline Main revenues & & \\
Capital income & 0.1 & 229 \\
Agriculture, forests and alpiculture & 61.5 & 137,575 \\
Tourism & 2.5 & 5,546 \\
Infrastructures for services & 8 & 17,987 \\
Leases & 22.5 & 50,300 \\
Leasehold estates & 5.4 & 12,072 \\
Revenues 2005 & $\mathbf{1 0 0}$ & $\mathbf{2 2 3 , 7 0 9}$ \\
Remaining credits previous years & - & 58,578 \\
Total revenues & - & $\mathbf{2 8 2 , 2 8 7}$ \\
Costs & - & $\mathbf{2 5 5 , 8 9 7}$ \\
Net income & - & $\mathbf{2 6 , 3 9 0}$ \\
Total asset ownership, including investments & - & $\mathbf{1 , 6 9 0 , 4 7 8}$ \\
\hline
\end{tabular}

Source: Canonica 2009. 
summarise the main data for the political municipality of Blenio and the PG-OCL.

The financial situation of the PG-OCL is secure, although in recent years the revenue from wood sales - due to the sharp contraction in market prices and the increase in management costs - have decreased significantly. ${ }^{4}$ Revenue related to alpiculture leased to the two alp corporations (Società Boggesi Lucomagno and Società Boggesi Valle di Campo), but also to individual administrators for the two small alps of Töira-Saltarescio and Carassina, remain stable, as do the leases and surface rights in the artisanal area surrounding the main settlement of Olivone.

\section{Regional and local specificities}

Although it is not a prerogative of the high lands, it is in the mountain contexts that the "commons" seem to have better resisted the "liberal attacks"; in other words, the agrarian reforms against ancient collective servitudes. The success of this process (becoming "a European fact" in the eighteenth and nineteenth centuries), and the destinies of collective goods, differed depending on local and national conditions and contexts (Bloch 1930; Demélas \& Vivier 2003). The mountains, however, are an ideal study area to analyse the socioeconomic and ecological role of collective management of forests and pastures in the long term.

Collective ownership is an ambiguous and multifaceted concept. Apparently, it implies an approach that is far from individualistic appropriation. Alpine communities, however, have always been familiar with the different systems of ownership and management, from collective management systems to individual systems based on private property (Netting 1976: 140; Ostrom 1990: 63; Lorenzetti et al. 2019: 21). This case study presents different specificities. In the jurisdiction of the PG-OCL the collective use of resources prevails only in terms of area, and in socio-economic terms its intertwining and complementarity with other forms of use (individual or mixed forms) were once significant. Nowadays, the separation of uses and land-use rights is by far much clearer than in the past, which reflects the profound transformation of society, agriculture and the perception of the territory. These changes are not only in land and resource management, but also in the internal administration of corporations and in interactions with other actors (private and central administrations).

In this chapter we will also deal with the peculiarities of the Canton of Ticino and Italian-speaking Switzerland at historical, cultural and institutional levels: a fragmented reality with reference to both the north and south of the alps. Since at least the Middle Ages, this region has been integrated into the economic and commercial circuits around Milan and other cities of northern Italy, with a strong demand for resources and work opportunities for immigrants (many of them from the valleys of Ticino). From the Early Modern Period, this region was, at the same time, politically and institutionally subject 
to domination by the cantons of the old Swiss Confederation, despite being characterised by a long tradition of autonomy.

The origins of the patriziati (corporations) in Ticino date back to the early nineteenth century, an era in which the so-called "communal dualism" arosealbeit with different outcomes in the various Swiss regions. In Italian-speaking Switzerland (and in large parts of the nation) this process prevented the incorporation of so-called "civic uses" (the commons) by the political municipality (Caroni 1964). The term "patriziato" seems to be of French import, as does "comune" ("commune" or the municipality). The first constitution of the Republic and Canton of Ticino dates back to 1803, but in Olivone as in other villages in the Ticino valleys, the following decades represented a long transition phase which led, not without conflicts, to the split between the municipality and the patriziato. With the first cantonal law governing the administration of patriziati in 1835, after burning debates, the administrative tasks were finally assigned to the municipalities, while the patriziati were attributed the management of the commons. During the nineteenth century, although the political municipalities rose in Ticino, the two institutional realities often remained indistinct. One can find a similar evolution in most of the valleys of central Switzerland, Valais and Ticino, where relatively closed local corporations and strong local autonomies could survive during the "long nineteenth century" (Guzzi-Heeb 2019: 119).

The first administration of the PG-OCL was created in Olivone, in 1845. The patriziato is a relatively recent chapter in the history of this community. The oldest documents in the local archive date from the twelfth century, a very dynamic era in these territories. The first mention of a vicinia (old community) in Olivone dates back to 1136 . We still can find hints of an administrative union between the three communities of Olivone, Campo and Largario within the Council of Olivone (Alivono) at the beginning of the thirteenth century, and a document from 1329 definitively confirms the union of the three villages (Meyer 1977: 31, n. 42). The oldest by-laws of the "Vicinanza" of Olivone - an administrative entity that roughly corresponds to the current PG-OCL - were issued in 1237 and, together with other documents, testify to the early "communalisation" of these lands. ${ }^{5}$ The community's expansion strategies for the acquisition of mountain pastures from other landowners such as nobles and ecclesiastical entities (Deplazes 1981: 120-124) can be interpreted as a reflection of this process. In the following centuries, the system of rules was gradually codified and further consolidated (Bolla 1931; Mondada 1959; Meyer 1977: 25 ff.). The centrality of this community, despite its location in the upper Blenio Valley, has established itself over the centuries and is testified to, in addition to in archival documents, by a vast and remarkable civil and religious architectural heritage.

The vicinanza of the ancien régime was a different reality compared to that of the patriziato, since it constituted an institution dedicated to the political, social and economic administration of all community practices (also including, in the villages, religious worship and the administration of local churches). 
The community wasn't limited to the collective management of resources, but was associated - well before the establishment of the nation states and their sedimentation - with an idea of "homeland". This was reflected in dynamics of exclusivism in the acquisition of the corporation citizenship determined primarily by birthright, especially during the modern age (Bolla 2000: $23 \mathrm{ff}$; Ceschi 2009: 6-11). In Ticino, the nineteenth-century patriziato, in opposition to the new-born political municipality, emphasised the "private and markedly patrimonial conception assigned to patrician rights", putting material and financial interests in the foreground, for example in the more frequent distribution of money derived from the exploitation of woods and the leasing of forests, and also due to the hegemony exercised by the local merchant class who were very active in forest speculation, as well as in the highest cantonal political circles. Over the course of time, the shift from local communities to the "communal dualism" and the newly established corporations reduced the meaning of governing the commons simply to land management, whereas before that, all community life had been administrated by the vicinanza (Bolla 2000: 27-28).

\section{Sources and methods}

The interviews for this case study took place in the patrician house of Olivone, in the room where the historical documents of the corporation are stored. The archive of the Patriziato di Olivone is very rich: it includes a few hundred parchments, thousands of paper documents and a few dozen volumes (copy letterbooks, minutes of assembly meetings, by-laws). Consulting these documents can lead one to quickly realise the importance of this community in the regional context. The sources that allowed the elaboration of this contribution are:

- complete transcripts of three semi-structured qualitative interviews with five local respondents (one woman, four men) made with a preestablished catalogue of questions very similar to that of the other case studies. The interviews ranged from 2 to 2.5 hours in length and were recorded and transcribed verbatim. The respondents were selected as experts according to their background. We focused on representatives of the corporations and other relevant organisations, such as alp or pasture cooperatives;

- notes made on the occasion of three inspections/excursions lead by local respondents, with partial recordings;

- archive documents, corporation regulations and other documents of the PG-OCL and the two alp associations:

- Boggesi del Lucomagno Company - SBL;

- Boggesi Valle di Campo Company - SBVC;

- statistical data, financial reports and a literature review, including some local and regional works of considerable historical and ethnographic 
interest that collected oral documents from the last century (Bolla 1931, 1935; Baer 2000 [1938]; Vicari 1985; Caflisch 1950).

The respondents, although with different sensitivities and varied interests, play or recently played a key role in their respective organisations (PG-OCL or alp associations). In their speeches and responses to our questions they often refer to history and the past, as if there is a direct guiding thread between today's administrative structures and those of the past centuries.

\subsection{The management of the alps: between change and persistence}

\section{A changing agriculture}

The number of farms, in particular small and family-scale ones (Table 9.4), and the number of livestock owners and units (Table 9.5) fell dramatically during the twentieth century in the Blenio Valley and in the study area.

Generally for the Canton of Ticino, but especially for the region of the PG-OCL, the figures in Tables 9.4 and 9.5 shows a massive decline in the period between the end of the nineteenth and the beginning of the twentieth centuries, which is also related to the transformation of traditional agriculture (Ceschi 1975: 112-124). This period saw the first phase of de-ruralisation. At the same time, the first agricultural reforms and alpine improvements were promoted by the Swiss Federal State. While Olivone shows some specificities compared to other communities of the Blenio valley in terms of still being very agrarian, the general trend shows a sharp decrease in the number of farms and also in the number of livestock owners. Still, cattle breeding remains important, because this area hosts

Table 9.4 Evolution of the number of farms and employees in the primary sector

\begin{tabular}{lrllll}
\hline \multirow{2}{*}{ Year } & \multicolumn{2}{c}{ Blenio Valley } & \multicolumn{2}{c}{ Municipality of Blenio } \\
\cline { 2 - 3 } \cline { 5 - 6 } & Farms & Employees in the primary sector & & Farms & Employees in the primary sector \\
\hline $\mathbf{1 9 2 9}$ & 1,036 & - & - & - \\
$\mathbf{1 9 3 9}$ & 998 & - & - & - \\
$\mathbf{1 9 7 5}$ & 354 & 886 & 119 & 294 \\
$\mathbf{1 9 8 0}$ & 308 & 656 & 113 & 217 \\
$\mathbf{1 9 8 5}$ & 263 & 592 & 96 & 213 \\
$\mathbf{1 9 9 0}$ & 244 & 507 & 95 & 190 \\
$\mathbf{1 9 9 6}$ & 180 & 407 & 69 & 161 \\
$\mathbf{2 0 0 0}$ & 182 & 406 & 58 & 139 \\
$\mathbf{2 0 0 5}$ & 153 & 372 & 49 & 129 \\
$\mathbf{2 0 1 0}$ & 141 & 341 & 44 & 115 \\
$\mathbf{2 0 1 5}$ & 124 & 318 & 37 & 107 \\
$\mathbf{2 0 1 8}$ & 119 & 320 & 33 & 101 \\
\hline
\end{tabular}

Sources: Caflisch 1950: 142; Federal Statistical Office 2019. 
Table 9.5 Evolution of the number of owners and amount of livestock

\begin{tabular}{lrrrrr}
\hline Year & \multicolumn{5}{l}{ Municipalities of Olivone, Campo Blenio and Largario } \\
\cline { 2 - 6 } & Livestock owners & Cattle & Goats & Sheep & Pigs \\
\hline $\mathbf{1 8 6 6}$ & $?$ & 950 & 1,549 & 416 & 503 \\
$\mathbf{1 8 7 6}$ & $?$ & 868 & 1,416 & 414 & 296 \\
$\mathbf{1 8 8 6}$ & 196 & 1,162 & 1,535 & 334 & 406 \\
$\mathbf{1 8 9 6}$ & 184 & 1,005 & 1,328 & 255 & 214 \\
$\mathbf{1 9 0 6}$ & 163 & 1,071 & 1,805 & 249 & 266 \\
$\mathbf{1 9 1 8}$ & 155 & 1,030 & 1,392 & 345 & 248 \\
$\mathbf{1 9 3 6}$ & 155 & 870 & 1,475 & 246 & 388 \\
$\mathbf{1 9 4 4 - 1 9 4 8}$ & 166 & 761 & 1,374 & 269 & 408 \\
$\mathbf{1 9 5 6}$ & 146 & 788 & 865 & 680 & 419 \\
$\mathbf{1 9 6 6}$ & $?$ & 822 & 393 & 531 & 214 \\
$\mathbf{1 9 7 3}$ & 81 & 723 & 354 & 568 & 78 \\
$\mathbf{1 9 8 3}$ & 59 & 821 & 445 & 27 & 53 \\
$\mathbf{1 9 8 8}$ & 54 & 832 & 262 & 109 & 14 \\
$\mathbf{2 0 0 0}$ & 33 & 753 & 134 & 456 & 13 \\
$\mathbf{2 0 0 4}$ & 28 & 771 & 141 & 618 & 5 \\
\hline
\end{tabular}

Sources: Federal Statistical Office (1866-1951); Federal Statistical Office (1956-1990); Federal Statistical Office (2019); Ufficio cantonale di statistica (2000-2019).

some of the widest and most productive alpine pastures in the Canton of Ticino. Most importantly, goat breeding, which had been one of the pillars of the local rural economy in the past, sharply decreased after the Second World War, with consequences on the process of forest transition. ${ }^{6}$ Goats feed on shrubs, and fewer goats led to the encroachment of forests by shrubs. They are also more labourintensive and thus there is a recovery in sheep breeding, as a reflection of the more extensive use of the territory. At the demographic level, the municipality of Olivone demonstrates substantial stability in the period between 1850 and 1941 (758 inhabitants in 1850, 750 in 1941), when the population of the Blenio Valley decreased by over 2,000 inhabitants $(-26.2 \%$, according to the Swiss Federal Population Censuses 1850-2000). Campo Blenio and Largario (small villages compared to Olivone), on the other hand, both experienced a strong decrease in population in the same period, mostly due to overseas emigration (Fiorini 2017).

To understand the evolution of collective uses related to alpine management, it is useful to retrace the traditional agricultural calendar (in force until the middle of the twentieth century) and compare it with the current one, which is very different from many points of view. An exhaustive description is reported by Bolla (1931: 245-246, 1935: 9 ff.):

Each Olivonese family has home and stalls in the lowlands as well as in the highlands, which are divided into Monti Mezzani, Monti Alti and 
Vesendari [sort of prealps]. On the first of May the Municipality decrees the "tensa" of the lowlands [a ban that sanctions the end of the collective grazing rights on private properties and cropland, the so-called "traso"] and then livestock must move to the Monti Mezzani. Meanwhile at home people did communal work by ploughing, cleaning the meadows and rebuilding hedges and fences. By the tenth of June at the latest, the Monti Mezzani were also subjected to the tensa and then a second emigration to Vesendari followed. The drive to alpine pastures took place on the tenth of July (third transhumance emigration). In the meantime, haymaking was completed in the lowlands and started in the highlands. In August the harvest was carried out and the sheaves of rye were dried on the characteristic "rescane". One the tenth of September the summering season on the alps concluded and livestock was driven down to the Vesendari or to the Monti Alti. They were gradually driven back to the Monti Mezzani in order to reach the lowlands by the first of November. A few days of traso followed, preceded by the potato harvest. With the first frost the rye was beaten. After that livestock could return to the Monti where they remain until March, when they were back to the lowlands. [...] The act of transporting livestock from one place to another is called "carent" in local dialect. "Ul di d'carent" is a day of celebration announced on the evening eve with bonfires .

It is also important to report that in the pezze comune in the Lukmanier area, cattle of the PG-OCL held the first grazing right from 25 May (if possible, depending on weather and snow on the pastures) until 29 June. This early occupation of the mountain pastures based on ancient rules gave rise to fierce protests over the centuries by the other corporations that had grazing rights on these surfaces. The cattle then returned temporarily to the vesendari before moving to the alps. From 10 July to 10 September, after the tensa (ban), the cattle of the other patriziati could then be summered on the pezza comune (Bolla 1935: 32-33).

Moving the livestock in different transhumance stages implied balancing fodder between private properties, on collective pastures and other commonpool resources (including surfaces inaccessible to livestock called fulostra and madair for wild haymaking).

Operations of central importance, such as the management of the alp, were carried out on the PG-OCL pastures individually by the single households until the 1950-1960s. There were already forms of communitarian organisation (e.g. for leading the herds to the pastures entrusted to herdsmen pastors or attempts to group the milk processing), however, the individual management of the alpine farms ("casadelle") remained deeply embedded in local tradition, as it did in much of the Blenio Valley and in other alpine valleys. During the summering season, single families managed the common pastures individually and were directly involved in the processing of milk. The family members finally met in the alpine huts after a very intensive season of work. 
The gradual shift in traditional forms of mountain pasture management is part of the transition phase between the end of the nineteenth and the middle of the twentieth centuries. In Olivone, attempts at alpine cooperation are documented from at least the seventeenth century (Mondada 1959: 3-6). However, in the Blenio valley forms of individual and family management of the alps (casadelle) were still present well beyond the midtwentieth century. The older respondents, who are the last witnesses of this ancient type of management that has now disappeared, linked the casadelle with an almost primitive management, and with very essential alpine buildings in which people, animals and the tools for milk processing used the same spaces. Elderly members of the commoners' organisations interviewed during the research for this case study in 2018 revealed that they were not definitively happy with the way things are managed today, but are also very critical regarding the past:

seeing how the alp is managed today is not to be believed as we were forced to work in the past. [...]. The generations that preceded us worked in an archaic way ...7

The oldest interviewee had experienced the whole evolution and is happy that things finally changed. He was indeed one of the people who wanted to change alpine farming in the Lukmanier area in the 1970s-1980s.

In the era of state-implemented agricultural and alp improvement policies, towards the end of the nineteenth century, experts began to emphasise the limits of this individual type of management. The corporative management of alps in Valle di Blenio was rather rare in the past. A survey carried out in the late 1940s in the Blenio Valley showed that in an alp with cooperative management (alp association) a person could manage five times more livestock units (corresponding to one cow) than the employees in family-run alps (Caflisch 1950: 147). In Valle di Blenio the associative forms of alpine management remained rather rare until recent times. The first cooperative units for milk processing in the villages (cooperative dairies) were created in the Blenio valley and in Olivone only towards the end of nineteenth century (Conto reso 1889: 145). In the context of transhumance, a family usually owned different buildings and homes, as well as land parcels scattered throughout the territory and distributed at different elevations. Land around the main settlements was mostly used for field crops. At higher altitudes there were the springtime pastures (monti mezzani and monti alti), where livestock was driven and kept even in winter, and where the private meadows for hay production were located. In the past, field crops were often cultivated up to $1,500 \mathrm{~m}$ in altitude, for example in Valle di Campo, but also in the mountains above Olivone, particularly for rye (Baer 2000 [1938]: 65-72). At the highest elevation was the belt of the alps, with areas called "vesendari" or prealpine settlements, where cattle grazed before and after the summer season. 
Compared to the past, the start of the summering season today is anticipated by at least 15 days, and in special cases even by a month, as GM reports:

Talking about it today ... to start summering on July 10 ... there would no longer be anyone willing to give you cows! [while] in the past, if you were discussing starting on June 10 someone would have put a gun to your head! ${ }^{8}$

Today cattle are driven to the alpine pastures much earlier than in the past. In the past the approach was more progressive. The abandonment of late spring pasture at high altitude today is linked to the centralisation of farms in the lowlands, while in the past the regulations governing transhumance (cattle driven between different sites and elevations) and the complex intertwining of user rights prevented early ascent to the alps. The anticipation of the summering season is undoubtedly an important change, linked to the transition to the corporate-cooperative management system that has definitively replaced the casadelle, and to the decline of traditional late-spring pasture practices rather than to climatic reasons.

The second phase of deruralisation, which took place after the Second World War, was much more marked and is linked to the profound transformations that took place in society. The casadelle disappeared between 1970 and 1990, above all due to the effects of the alp improvements and reorganisations, first in the Valle di Campo and, later, in the Lukmanier area. An old commoner remembers this transition well:

the epochal change for all took place after the Second World War, it was slowly changing the world $[\ldots]$ and we here ... we were lucky enough to take over at the age of 15-16 [...] at the right time of the big change. ${ }^{9}$

Alpine farming and livestock movements have changed profoundly, with the creation of the bogge (alpine associations) from the 1960s onwards, and the subsequent disappearance of the casadelle, and more completely from the years 1980 to 1990 with the transition to modern agriculture. Many farms on the lowlands keep their livestock in modern open stalls and benefit from cuttingedge milking technologies for most of the year, and drive cattle directly to the alpine pastures in mid-June. Today's cattle are bigger than those of the past, which implies a greater impact on pastures (Figure 9.3). There is less mobility, and less accessible land has been abandoned, favouring an increase in shrubs and forest. Among the interviewees there are those who note, paradoxically, that the end of the traditional family-run alpine farming that coincided with the transition towards a more rational management, organised in alp associations, seems to be less effective. In reality, the profound changes in agriculture and society made inaccessible and non-mechanically manageable areas simply less interesting from an economic and agronomic point of view. Moreover, there is the problem of future generations not taking control and supervising the alpine pastures (the alpine supervisor is almost 80 years old and virtually unpaid). 


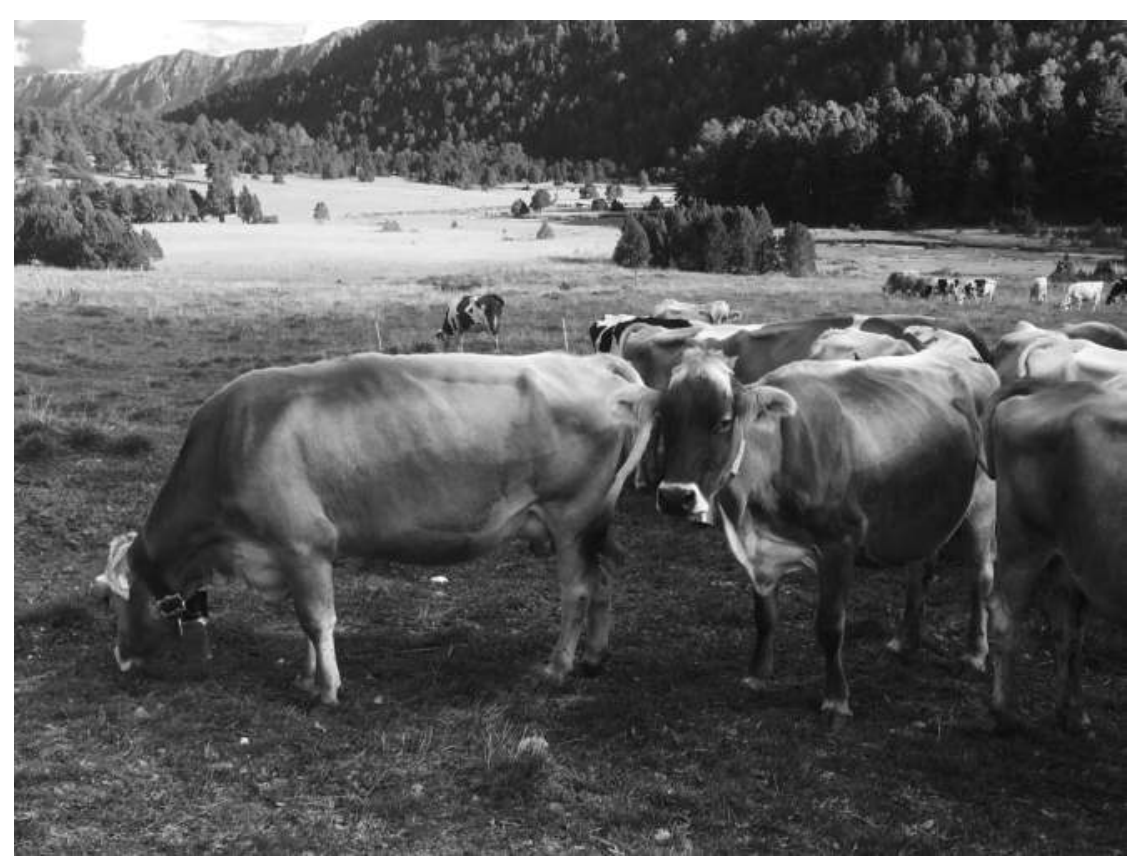

Figure 9.3 Herd of cows before evening milking at Casaccia (Lukmanier). Source: Picture by Tobias Haller, 2019.

The management of the alps and grazing rights was highly articulated at both a spatial and temporal scale in the commoners' organisation, as in other alpine communities. Changes in recent decades have led to the significant simplification of this set of rights and rules. The future improvements and new entities imply important changes. GM and FZ well remember the conflicts provoked by these changes, and the persistence of ancient uses, as recalled in the following statement:

It took at least 40 years to get rid of the rights of these last elderly farmers. Fights ... when we merged the small alps into the alp cooperatives [...] the meetings were maybe until three in the morning! A squabble! [...] Nowadays [we farmers and boggesi] all get along. While once ... even among the boggesi [members of alp cooperatives] there were those old guys linked to the casadelle who kept the old regulations on the table, to say ... you could not ... At one time they got to the point of fining a hen ... for invasion of property! $!^{10}$

The improvements on the Lukmanier alp were realised only in the 1990s, over 20 years later than in the Valle di Campo. This was mainly due to disputes with 
other corporations with which the PG-OCL shared grazing rights over the vast area of the pezza comune. Conflicts between the corporations also rekindled after the Second World War, due to the indemnity of damages paid by the Swiss army, as reported by the former president of the PG-OCL:

At the time of the improvement of the new Lucomagno alp there were significant conflicts [...]. Now, however, there is an agreement, but it was difficult to obtain it [...] since at that time [1980s] the army still used the area for shooting exercises. And there was a lot of money, the real question was related to the distribution of money. ${ }^{11}$

An agreement among the corporations came into force in 1988 and was renewed in 2009. Today a de facto division of the territory during the summer season has been achieved, while guaranteeing ownership of the PG-OCL on the common pastures and grazing easements in favour of the other corporations. In the past the ancient agreements allowed the rotation of pastures among the different communities. Before the agreement, the situation of possession and rights of use in the shared lands was more complex, regulated with very specific kinds of use as a result of centuries-old disputes. Today, in a society in which property regimes tend (or pretend) to be relatively clear, it is difficult to understand the reason for these multi-layered use rights. In the past everything revolved around the controlled management of fodder resources and pastures. Such strategies were the result of complex historical paths that led to the rise of these pasture easements, and to shared use rights.

We were able to talk with alpine administrators, livestock owners and the cheesemaker of the Lukmanier alp during our excursions (Figure 9.4). There are major financial issues involved in making cheese and other alp products in a context of the reduced relative value of alpine foodstuffs, due to increasing hygiene and label standards, the rising construction costs for new structures, the increasing need for a cooling system during summers that are warmer and warmer, as well as requiring respect for animal protection and environmental rules. Are the corporations able to make investments and maintain such high standards over the long term? Who will pay for the services that the patriziati or alpine corporations provide? Should the rules be adapted to the particular conditions of alpine farming?

\section{New forms of use between conflict and opportunity}

In 2000 the PG-OCL was awarded the Binding Foundation Prize for exemplary forestry, in recognition of the important projects developed by the commoners' organisation in recent times, such as the management of protected forests and the creation of the Selvasecca natural forest reserve in the Lukmanier area, which has renounced management to encourage the natural evolution of this old-growth Swiss stone pine forests. The PG-OCL, in collaboration with other actors, also promotes "slow" tourism in the area, focused on hiking, nature and landscape conservation. As reiterated by NS (the current vice-president of the 




Figure 9.4 The alp cellar of Pian Segno (Lukmanier) and the president of the alpine association SBL. The summer production of PDO cheese exceeds 3,400 blocks produced with the milk of 220 cows. Source: Picture by Tobias Haller, 2019.

commoners' organisation), one of the main objectives of the PG-OCL today is to maintain a widespread network of hiking paths and trails:

There was a period in which the tourist office wanted to abandon certain paths due to maintenance costs, in favour of the roads. In this case we set ourselves up and we felt it was right to keep them [...] Then for the mountain bike trails we always cooperated and let it go, with some differences with the farmers who, paying rent for the alps, found fault for a series of inconveniences caused by cyclists. [In addition] on the Lukmanier Alp in summer there is always a person employed by patriziato, the municipality and canton, who provides tourist information and raises awareness about maintaining a certain order in parking lots, and to prevent littering. That's a nice service! ${ }^{12}$

These elements testify to particular attention being paid to the new forms of land management established in recent decades, based on constructive 
collaboration with other actors, but not without comparison and inevitable conflicts between the PG-OCL administrators and other interest groups more progressive in the circles of the environmental associations and cantonal services, generally more conservative in those of farmers and on the part of the local population. Tourism and the current importance of issues related to nature and biodiversity conservation are of central interest for the PG-OCL, especially in the precious Lukmanier area, crossed by a mountain road which is in use all year round, at the crossroads of hiking trails that are very popular, especially during the summer season. There are also winter sport resorts in the PG-OCL, but the role of the corporation is more marginal here.

In recent decades the traditional needs of alpiculture have needed to adapt to deal with the goals of nature and landscape conservation in the Lukmanier area. It is a coexistence that poses new questions and new challenges for the corporation, as reported by NS:

Definitely the issue of peat bogs [with the registration in 1996 in the Federal Inventory of the marsh areas of national importance of Lukmanier with consequent restrictions on grazing] not everyone has swallowed it. Or the imposition of the evening pasture of cows in a certain area. Somehow these conflicts have been resolved, at some point someone had to give in from their position $[\ldots]{ }^{13}$

Ownership of PG-OCL in the Lukmanier area includes a network of protected wetlands of national importance, in which alp management plans define fenced sectors where grazing needs to be removed to allow for nature and biodiversity conservation, as reported by FZ:

Once cattle grazed there [in the bogs] or sheltered from the weather, so to speak, but in some ways it is better because cattle grazing in a "bolla" [bog], as we say ... there were problems with cheese production: that was also one of the causes of "puffy cheeses". Now these areas are fenced and we get monetary compensation. ${ }^{14}$

FZ experienced the transition to the current role of agriculture and the need to deal with new forms of use with more foresight. The Dötra plateau, for example, is today an area recognised nationally for the presence of dry grasslands and humid environments that make it an extremely interesting ecological mosaic, for the flora, and both the terrestrial fauna and the birdlife. Between the 1960s and 1990s this very sensitive ecological area near the Lukmanier was the scene of a struggle between environmental associations and the promoters of a big tourism project that involved the creation of a winter sport resort capable of hosting up to 5,000 people in an area of over 50 hectares at between 1500 and 2000 meters above sea level. This battle was won by birdlife protection associations, and has led to the creation, in cooperation with the public bodies, of a 
foundation that has taken over these areas and is now responsible for conserving and enhancing the conservation of these environments.

Nowadays the Dötra area is extensively managed by farmers from Olivone (including FZ, among others), and with very specific criteria.. As previously, the PG-OCL still holds rights that were exercised by the SBL after the end of the summering season. This is a unique example of past collective servitudes in Ticino. Cattle (about 100 cows) are transferred from the Lukmanier alp and graze for 10-15 days in these private mountain pastures. In order to harmonise agriculture and nature conservation, an interconnection project has been active for several years throughout the area, promoted by the foundation. Sixteen farms have joined it and they manage an area of over 400 hectares, one third of which is managed extensively or slightly intensively to promote biodiversity (Società Agricola Bleniese 2015: 5). This area also includes the highest meadows for hay production in the Canton of Ticino, rising up to 1900 meters above sea level, to which late mowing criteria are applied. FZ considers the balance of these operations to be very positive:

If the Dötra area had not gone in this direction, it would have been abandoned, while today there is a real maintenance of the territory. This must be emphasised, because if we look at the yield of the meadows it would be more loss than profit. $^{15}$

As mentioned, the Lukmanier area is also a very sensitive area for landscape and biodiversity conservation. The Consultative Commission in the Lukmanier marsh area - with representatives from the cantonal offices, the PG-OCL, the SBL, the Municipality and the Regional Tourism Organisation is another example of a platform for the exchange of information and experience among groups, and the promotion of conservation projects. The balance even seems positive from the PG-OCL perspective, as the former GC secretary concludes:

I think coexistence works. [Farmers] also begin to understand that hikers will perhaps go to buy cheese, yogurt, etc., and therefore there is a return. [...]. The regulations are more strict, but the management of the area could improve with the new infocentre. ${ }^{16}$

The Pro Natura environmental association acquired and relaunched an educational, tourist and naturalistic centre in Acquacalda in 2010. In 1985 it recovered its ancient vocation for hospitality, which was attested in the Lukmanier area at the beginning of the twelfth century by the presence of hospices on the pass road. At one time, ecclesiastical bodies assisted travellers in transit, and today new forms of hospitality arise for tourists and hikers, to which the PG-OCL also contributes by making available two buildings renovated at the former Samprou alp farmhouse. The corporation 
also owns numerous buildings in the mountain belt, acquired through bequests and legacies. As NB recalls: "The PG-OCL has rented them out at very low prices with the condition of maintaining and managing them, preserving their integrity and the ownership of the corporation. They are 30-year contracts"17. This can be considered a "social housing" operation, stemming the abandonment of the territory, obtaining small revenues and complying with the cantonal rules governing the corporations which prohibit, in principle, the alienation of assets.

Revenues related to tourism have increased compared to 2005 (camping, the new infocentre and parking on the Lukmanier), although this is only a small percentage of its income. In 2019, an ambitious tourist revitalisation project was presented to the population of the municipality. The goal of the project is to improve the offer of accommodation in the Soprasosto area. It consists of a set of projects and initiatives that aim to revitalise and create new input for tourism in the area of Campo Blenio and Ghirone. A newly created association will propose more welcoming and up-to-date structures, and the development of a network of leisure offers in a "branding" operation in order to fully exploit the potential of this territory within a recreational profile. This offer focuses especially on summer tourism, and is particularly aimed at the owners and renters of secondary residences and hikers attracted by the Greina region with its alpine huts and its natural and cultural landscape of great value in biodiversity. Unsurprisingly, the son of NB, who is a member of PG-OCL and of the municipal council of Blenio, will preside over this association. The project is enriched by various initiatives that range from sports activities, new camping methods (glamping) and recreational-educational itineraries. As mediators and landowners, the local corporations (PG-OCL and other patriziati) will be able to play a key role in the development of these projects, which make sense on paper, but which need to be understood and "made their own" by the population. It remains to be seen whether this will mitigate the problems of the commoners' organisation, however.

Other examples could be cited - such as the hydroelectric basin project first proposed in the Lukmanier and Greina areas (Kaech 1946), then scaled down and built on the Grisons side at the Lukmanier Pass and in the Luzzone valley. The construction of the Luzzone dam in the 1950s and the strengthening of the hydroelectric power plant in the 1990s was a valuable source of income for the PG-OCL. The exploitation of water rights and the hydroelectric sector on commons requires specific study; however, the advent of this kind of exploitation, and also other uses such as winter tourism or military activities, have brought capital and new forms of income for commoners organisations, modifying the traditional schemes of collective management, creating opportunities and sometimes also having implications for ecology, sometimes fuelling and exacerbating conflicts over the original use rights. On the other hand, the strong external interest in tourism and nature conservation affects the traditional operations of pastoral areas in different ways. 


\section{Synthesis}

The profound changes in agriculture that have taken place over the past century and the emergence of new forms of land use in recent decades pose many questions. Balancing these changes has both challenges and benefits. On the one hand, new orientations towards ecosystem services frequently collide with mountain agriculture, which in this region is traditionally oriented towards cattle breeding and dairy production. The collective management of the uplands has to deal with significant challenges, but still generate significant revenue for the corporations. Agricultural issues are no longer at the centre of the debates and agendas of corporation assemblies, as they are mostly regulated in other venues (bilateral meetings between the concerned actors, exchange platforms, cantonal and federal policies). Today agriculture employs a very small number of people compared to in the past, when all commoners were directly involved in rural activities. Until the late twentieth century, the by-laws, regulations and assembly meetings of the PG-OCL involved agricultural issues, transhumance practices, the successive phases of the rural calendar, or agroforestry practices, down to the smallest details. With the affirmation of cantonal and federal laws, these regulations have now lost importance. Farmers are less and less represented within the corporations and often no longer available to play an active role in them. The management of collective agricultural land is now entrusted to a few farmers who must maintain and exploit much larger areas than in the past, in a context that is also very different in terms of professional expectations and prospects. Breeding and cattle selection have brought undoubted advantages, but also have intrinsic limits. There has been a dramatic decrease in small livestock during the last 70 years; heavier animals have a greater impact on pastures and they do not allow the exploitation of the remote and steepest areas, which are consequently abandoned. The PG-OCL has promoted initiatives to counteract abandonment and encourage new forms of use, but is it enough? Many questions arise as a function of the numerous challenges related to alpine farming.

\subsection{Forest management: from the "omnipresence of wood" to forest transition}

\section{The changing role of forests}

In the past, forest management was, like agriculture, a central aspect of life for the local population. The old by-laws since the end of the fifteenth century, as well as the minutes of the assembly meetings since the end of eighteenth century, show a recurring need to delimit protected forests (so-called "faura"), protected for economic reasons and for their protective function against natural hazards. On the other hand, regulations governing wood and non-wood forest uses in specific or more generic terms constituted a strategy to avoid abuse and bring order to the concessions. This is mirrored by the growing exclusivism 
exercised by the original families in the use of collective goods during the modern age (Bertogliati 2014: 33 ff). The existence of a "wood crisis" in the pre-industrial era has been partly called into question by German language historiography, since the complaints of forestry experts and central authorities very often concealed precise programmes aimed at limiting local autonomy, cancelling collective use rights and excluding certain population circles (Radkau 2014: 13 ff)., A true "era of forestry regulations" arose throughout Europe between the sixteenth and seventeenth centuries (Radkau \& Schäfer 1987: 101) which is also reflected in the alpine area. The establishment of forest constraints can be read as a further reflection of the "communalisation" process and development of the institutional structure of upland communities.

To an even greater extent than in the agricultural sector, the regulatory system in force for the forestry sector today differs considerably from that practiced in the past. Since the end of the nineteenth century, control over forest cuts and silvicultural issues has gradually been transferred from local communities to the central (cantonal and federal) authorities that have their own local administrative offices in the region. It is no longer just the local wardens or "rangers" who control and possibly sanction forest crimes, but new emerging actors. Public officials (foresters and forest inspectors) operate on the basis of federal and cantonal forest laws, which are often in opposition to the agricultural needs of the population, albeit at the same time promoting important land protection works.

The direct economic revenue from forest management has today decreased significantly compared to the past, due to the epochal changes that have taken place since the Second World War and, in recent decades, to the transition to a modern forest management focused on a more holistic perspective and on a near-to-nature silviculture, considering the importance of ecosystem services and other forest functions. The collective forests in the "coffers" of the corporations became an important expense item in the 1980s mostly due to the increase in average labour and forestry operations costs, as well as the fall in wood prices (Bertogliati 2015: 277). NS, younger than the other respondents, but a trained lumberjack and previously head of the local forestry company, focused on this aspect in particular when he stated that:

The economic function of forests has been somewhat forgotten. Until a few years ago, firewood was still very required, everyone cut wood or often came to the corporation to request it. Now there is hardly anyone left $[\ldots]$. And the recreational function of forests increased in recent years, bike trail paths were created and even in the management of the hiking paths we have never backed down. To promote local firewood such as patriziato, we have [also] created a wood chip plant, [...] and in that sense a district network has been created that heats several public buildings and private houses. [...] This is an example of collaboration between the municipality and the PG-OCL. And this plant is powered almost entirely with timber from the cuts of collective forests owned by the PG-OCL or in any case in the municipal territory of Blenio. ${ }^{18}$ 
NB also highlights the latest trends. The price of spruce timber only dropped by more than 25\% in the period 2015-2019. Raw wood prices have decreased since 1950 and labour costs in forestry have increased dramatically (Niederer \& Bill 2015):

In the past, the PG-OCL from an economic point of view focused mostly on forests ... on timber ... Now from the forest ... nothing is obtained, practically! Machine and labour costs have increased, most of the logging is done with helicopters, fast and comfortable so we say, but expensive. And timber prices are low. Maybe 60 francs per cubic meter, and it must be good. ${ }^{19}$

Nowadays, forests in the Swiss Alps are mostly managed for their protective function against natural hazards. This function was recognised for centuries by the alpine populations, but became the focus of forestry concerns only in the past 150 years. This was a paradigm shift that started in the nineteenth century and introduced the prohibition of clearing in Switzerland, development of the principles of near-to-nature silviculture, and recognition of the social (protective or recreational) functions of forests (Bertogliati 2014: $186 \mathrm{ff}$ ). Thanks to subsidies and other kinds of support from the cantonal and federal authorities, the importance attributed to the different functions of forests in the Swiss mountains means that forestry activities can still be carried out, albeit at a much lower intensity than in the past. Since 2008, public subsidies for these operations in Switzerland, with few exceptions, are afforded in the framework of programmatic agreements between the cantons and the Confederation, which provide financial support for specific performance and quality indicators. In this profoundly changed context, the proactive role of the corporations in Ticino has now waned, as NS reiterates:

Cantonal forestry law is [now] more important, because the corporation regulations in some respects are no longer widely used or applied [...] Mostly because they include articles related to past management or use rights. In the past, however, each family had its own house mark that was carved into wood that was sent to auction or requested by the assembly. ${ }^{20}$

This is simply a reflection of the dramatic changes that have occurred in recent decades. The system of rules to which users must now refer is now more complex on several levels. A corporation regulation today often contains rules which in daily life no longer have such a strong effect on members.

On the southern slopes of the Swiss Alps, the special conditions from the administrative, institutional, infrastructural, climatic and topographical points of view impose greater constraints than in the regions on the northern side. Some corporations have their own forestry companies and therefore have a more direct interest in promoting forest management. The case of PG-OCL can be considered intermediate, since it does not have its 
own forestry team, but together with the other corporations of the Blenio Valley in 2017 reconstituted the Valley Community by acquiring a forestry company which is presently very active. This also allows it to maintain a certain number of jobs and have an effect on the local economy. ${ }^{21}$

We quote NS again, an interviewee who is certainly competent in forestry, and whose concepts are also repeated by GC and NB:

With the forest company we could still manage our forests. And with the cantonal authorities the modus operandi is discussed and you never find yourself with a fait accompli, you evaluate the setting of the project or intervention together from the beginning. And during the work there are always meetings that allow you to discuss things and find solutions. There have never been any issues or differences about the forest. [...] Then the forestry company brought other companies and people to work here in the valley, for example for wood transport. ${ }^{22}$

The PG-OCL plays a central role in this new entity, the Valley Community, due to their territorial importance and above-average financial abilities, so much so that NB (former president of the PG-OCL) also presided over it. As NS points out:

Forests have always been of central importance for us. [...] Above all, the community of Olivone has always had a tradition of forestry, even if in some contexts today we should talk more about a leisure forest (for example on the Lukmanier area) than about an income forest [...]. And we invest part of the revenues derived from other sectors in the forest projects themselves, that's to cover the remaining costs after deducting the sale of timber and the cantonal and federal subsidies. A large part of our revenue is invested in land maintenance. For example, we now have a forest project in the lower part of the Valle di Campo [...]. Costs are estimated at about 900,000 francs and we are the promoters. Its main goal is to recover ancient grazed larch woodlands. Here we collaborate with internship courses with apprentices [...]. We are also planning an avalanche warning project in the Lukmanier area, focused on protection for the road. Costs will exceed 10 million francs and we will do our part. ${ }^{23}$

The realisation of such projects is favoured both by the high rate of public subsidy and by the good relations maintained between the corporations and the cantonal forest service in the last two decades. However, the question arises of whether their own financial resources will be enough. The forest service certainly plays a valuable role as consultant for the project development and in the conservation of the cultural landscape. It is a collaboration judged very positively by the respondents, as opposed to that with cantonal services in the agricultural sector, which is considered more distant and detached. It is also a 
fact, however, that forest management corporations also have less autonomy than in the past.

In Switzerland silvicultural interventions in protection forests, now widely recognised by the population, rest entirely on the high subsidy quotas by cantons and the Swiss Confederation (about 70-80\%). The financial support of the central authorities allows guaranteed minimum care of the protective forests, ${ }^{24}$ and, at the same time, generates economic returns in the valleys and ensures other services offered by the forest ecosystem (e.g. recreation and conservation). In this sense, the role of the patriziati, as the heirs of ancient local communities, is still relevant in forest management and land-use planning. Where the corporations are weak or do not have the financial and organisational resources to play this role, the political municipalities or other actors must take over. In the valleys, a closer collaboration with the municipalities, following the recent trend towards the merging of municipalities into bigger and more complex administrative structures, is unavoidable. Corporations could divide costs and possibly delegate some administrative burdens, and in the meantime, municipalities could find interlocutors who know the area well, are anchored in the local communities and usually have more experience in the field.

Uncertainties remain regarding the economic fragility of corporations, however, which in Ticino only rarely benefit from tax revenues from their members; in the contexts of mountain and marginal areas they do not have significant financial and human resources to promote different projects simultaneously nor, often, to meet the remaining costs after deduction of public subsidies.

\section{Forest cover increase, decline of traditional uses}

The words "forest transition" mean a change in forest cover from a phase characterised by deforestation to reforestation, which is common in industrialised countries (Mather 1992). Generally seen negatively by local commoners and farmers, this process is unavoidable and reflects the socio-economic transformations that have taken place in the last 100-150 years: the sharp decline of the rural class (number of farms and employees in the primary sector), the dramatic decrease in small livestock (especially goats), the paradigm shift in forest management and abandonment of traditional agroforestry practices (e.g. wild hay on steep slopes and forest litter harvesting, free seasonal grazing in forest and cultivated fields).

It was during the first half of the twentieth century that we could see the abandonment of the madair, which were small plots in remote areas of the Blenio valley where wild hay was mown. Wild haymaking was (and still is in some areas) an emblematic, very risky and traditional practice in the Alps. The production of wild hay meadows in the mountains during the late summer provides far less hay than other meadows in lowlands (Caflisch 1950: 143). This practice, however, represented a very valuable form of integration for the local population, not only in the contexts of self-subsistence, 
but also in the valleys of the Swiss Alps, whose alpine production in the course of the modern age was increasingly oriented towards the export of cows and dairy products (Blatter 2009). In the Olivone area, the assignment of these surfaces was carried out by means of auctions which involved 100 plots over a total area of several square kilometers. The PG-OCL was always the owner, but its use was the prerogative of the so-called "internal commoners" of Olivone, who belonged to a sub-corporation which held its own assembly on the first Sunday of June, which had among its primary purposes the division and the auction of wild hay meadows (madair or sorti). There were already signs of decline in this traditional practice at the beginning of the twentieth century, as it was very demanding and risky, according to Guido Bolla who was secretary and member of the Municipality of Olivone at the time, as well as a local historian:

The denomination "sorti" suggests that in ancient times instead of the auction the allocation was determined by the drawing of lots. Today, however, the auction price is often very low: many lots are awarded at the price of 10 cents, just to keep the right $\ldots{ }^{25}$

In addition to the madair there were three fulostra where there was an apparently even more ancient right, namely that of the first occupant. On 10 July, coincidentally the same date as the start of summering season, a commoner who wanted to ensure the right of wild haymaking had to reach these inaccessible and remote sectors and affix the symbol of their house, but not before shouting three times that they were taking possession. The fulostra was abandoned around 1950, however, and the lots of the madair were grouped into one area and distributed every five years (Caflisch 1950: 143) until their final abandonment in the following years. It is important to consider such apparently marginal forest uses in order to understand the relationships between commoners and non-commoners, once very conflictual. Today the social and economic differences between these two categories are imperceptible due to the decline in traditional management, as NB suggests:

In the past, commoners had advantages. Especially for wood. And then for the "sorti" where wild hay was made. Commoners had an advantage over that. Today we can say that in practice there are no more differences. Who is going to collect wood today? Hardly anyone anymore! Nor make wild hay either. ${ }^{26}$

NS reiterates the same concept regarding the disparities between commoners and other residents:

Today there are no advantages but no disadvantages either. At least in the present, in the past there were certainly differences between neighbours and non-commoners. According to the documents I consulted, commoners were always favoured. To have a tree, a piece of land ... there were greater benefits, certainly! Very detailed tender specifications were drawn 
up for the sales of standing timbers. [...] On the mountains, many of which have been covered by bushes today, there were the famous "sorti" that once a year entered into competition. They were lots for wild haymaking, some in specific remote places ... and they paid certain amounts, in my opinion very high! For such remote places ... ${ }^{27}$

In addition to the decline of traditional agroforestry uses, one of the main drivers of forest cover increase and the abandonment of agricultural land was represented by the decrease in goats and sheep. The decrease in small livestock in the Blenio Valley, with the increase in the number of large livestock units, is one of the most relevant agricultural dynamics of recent decades (Società Agricola Bleniese 2015: 4). NB (born in 1950), performed the function of goatherd as a boy during the summer on the Alpe di Gana, which was grazed only with small livestock:

Then the goats, unfortunately, disappeared. The cheese was previously mixed, now it is made only with cow's milk. Nowadays the goats of the Blenio Valley move almost all to the Alpe Stgegia [belonging to another corporation, the Patriziato di Dongio, beyond the artificial lake of Santa Maria, on the territory of Graubünden]. ${ }^{28}$

The role played in the past by small livestock, particularly goats, also comes back strongly in the speeches of the other respondents. GM:

The forest has become wild mainly because, starting from the protection plantations that they created, rightly ... which however triggered the conflict between agriculture and forestry because there was the small livestock that [browsed on juvenile plants]. And so we started to fence the forests with barbed wire and so on, and the number of farms and small livestock decreased, [...], then all the farmers were forced to specialise in producing more milk without wasting time doing anything else and the incentives then meant that now almost no more small livestock is raised on the farms. Farmers from the northern side of the alps also came with their cattle [...] to continue managing the steepest alps. In Olivone and Aquila on the mountain pastures that in the past were grazed by a thousand sheep, what happened? Ungulates infiltrated, deer, roe deer, etc., because there were none of these deer 60 years ago as there are today [and] now they begin to realise that in certain places they are not under control and they also do damage ... which must be compensated. $[\ldots]$ They are the downsides $[\ldots] .^{29}$

These positions reflect the locally perceived impact of the shifting of agriculture and the epochal transformation of society over the past century. The fight against increasing forest cover and the consequences of abandoning agricultural areas require important investments and systematic measures, which are 
difficult to implement across large mountain areas. This prompts a certain pessimism in respondents, especially farmers such as GM:

It was a lost struggle from the start ... the most difficult areas were abandoned. Support from the authorities in this area is crucial [...]. In nonmechanised areas it may also be okay for the forest to come back, but not where there is the possibility of having suitable land and agricultural surfaces $[\ldots]$... well, here you should have greater consideration of the needs of mountain agriculture. As for the alp, it is clear that if there is no substantial public support to contain this dynamic, the upper limit of the forest is destined to rise progressively ... and therefore, we, as an alp cooperative, try to do what is written in the contract [lease of the alp], that is, trying to keep small trees and anything else under control, sending people there for a week or more to cut ... there is a person or two who do that every year, but even if you do this, you cannot fight the forest invasion, and therefore more ... [incisive] measures should be taken on this issue, $[\ldots]$ otherwise along with the current grazing system ... given the lack of goats that in the past were the first forest fighters ... ${ }^{30}$

In addition to the management of mountain pastures, also in agroforestry one can find in the past other examples of commixtures of private and collective uses. One example is the cultivation of chestnut and walnut orchards through the jus plantandi, an ancient use right still attested in the early twelfth century in the lowlands near Olivone (Figure 9.5), which consisted of the right exercised by individuals to plant fruit trees on collective land (Laurianti 2017: 269). The traso, or the collective easement of the free pasture in private cultivated funds from 1 November to 1 May, which was still practiced until the second post-war period, is another traditional agricultural use for which we have evidence (Bolla 1935: 9, 44, 80).

\section{Synthesis}

Today, with the increased labour costs and the advent of a global timber market, the revenues linked with forest management are of marginal importance for corporations. This trend began in the 1980s, although it has increased in the last decade. Current forest management is based mainly on the enhancement of ecosystem services offered by the forest, and in particular the protection against natural hazards which is clearly the predominant forest function in the alpine area. The conservation of biodiversity and landscape were also found to be important in this case study, through special interventions or the creation of forest reserves. The current direction is influenced by the paradigm shift that took place at the end of the nineteenth century, with the transfer of control over forest management from local communities to central authorities, the recognition of the role of the forest in the balance of nature and the implementation of forest reforms. This dynamic is closely linked to the "forest transition" process, or, in other words, a reversal of forest cover change trends from a very long 




Figure 9.5 The Olivone plain with the characteristic Sosto peak in the background in 1926. The steepest and almost vertical areas were used for wild hay harvesting. Source: ETHBibliothek Zürich, Bildarchiv/Author: unknown/Ans_12466/Public Domain Mark.

phase of deforestation to a reforestation phase. The increased forest cover is very relevant and rapid in the alpine area today, and, in particular, in the study area. The loosening of traditional collective uses and the decrease in the number of farms and farmers have favoured the abandonment of several hectares of grassland and pasture areas, which is a strong increase in forest cover not only in the most inaccessible and remote territories, but also around the main settlements. In the context of collective management, the role played by the PG-OCL today is less proactive, since the constraints linked to cantonal and federal forest laws and the changed socio-economic context reduce its autonomy in a way. In this sense, the cantonal forestry service plays an important role both in terms of consultancy and by financing silvicultural and technical interventions, today largely supported by public funds. Not all costs are met, and much more support is needed, along with a local definition of what this support should look like.

\subsection{The internal organisation: a complex (in origin) reality}

\section{A changing role, different perceptions}

According to the cantonal law (LOP) governing the functioning of these corporations in the Canton of Ticino, "the patriciate is a corporation governed 
by public law, autonomous within the limits established by the Constitution and by the laws, which owns common goods to be preserved and used in a commoner spirit in favour of the community". It is necessary to consider the expression "commoner spirit" 31 .

This concept has to do with both the connection of commoners to their roots, and with the awareness of playing a precious role for the entire community. This programme, however, has to deal with society's loss of awareness of this role. This is, at least, the personal opinion of GC (former secretary of the corporation):

Many people do not have a perception of what the patriziato is. Most, especially non-local people, although they are interested in municipal issues, do not have a very clear idea what it represents today, what it was in the past and what it still doing today and its importance for the municipality. [...] There are many who are commoners but who have no interest and, by not attending the assemblies, they are exactly like the others. ${ }^{32}$

Until the early 1990s, when GC took on the role of secretary, assemblies were decidedly more animated.

The interventions during the assembly meetings today are more quiet and thoughtful, while in the past I had some assemblies in which [...], having to write the minutes, I wrote "animated discussion followed" because at some point it is better not to write anymore [...] also because you could no longer keep up with this or that. Now everything has changed. ${ }^{33}$

In Article 37 the Swiss Federal Constitution defines citizenship rights and states that "no one should be favoured or disadvantaged because of their citizenship". The only exception is "the provisions on political rights in corporations, as well as on the shares of participation in their patrimony, unless otherwise provided by cantonal legislation". This sentence confirms two important points: on the one hand, it sanctions the constitutional guarantee of the existence of corporations; on the other, it provides for decision-making autonomy and competence on the part of the cantons in setting limits to the rights of these entities. The Canton of Ticino, in fact, presents a peculiar evolution at an institutional level in terms of corporations and their autonomy. The LOP (cantonal corporation law), in force since 1835, with important revisions in 1857, 1962 and 1992, regulates the principles and sets the margins for manoeuvre in the administration of these institutions under public law, as envisaged for political municipalities. This limits, in many ways, their autonomy with respect to other Swiss corporations.

Over the past two centuries, the very existence of these institutions has been repeatedly questioned at a political level, which has favoured the development 
of solid legal bases that regulate their functioning today. There are, for example, rules that clearly define the criteria for acquiring commoner status, the principle of inalienability of corporation assets, as well as the role of surveillance and advice given by the cantonal authorities. These constraints have led to redefining the very relationship between corporation and other public bodies. The case of the Canton of Ticino, as part of the peculiar development of municipal dualism, is therefore very interesting.

We particularly addressed the issue of "naturalisations" with the respondents, that is, the acquisition of the status of commoner by residents. We have seen how in Olivone at the beginning of the twentieth century, the majority of the inhabitants were neither commoners nor natives (Bolla 1935: 33). Conflicts between commoners and non-commoners in this community were already documented in the nineteenth century. The search for a balance between these circles was, however, essential, in order to ensure a livelihood for all residents and the management of a very large territory, in an era marked, in the valleys of Ticino, by massive overseas migration. Exclusivity for a long time meant that foreigners had little room to manoeuvre, but if they were useful to the local economy, they could also enjoy a certain freedom (Head-König 2003: 108; Bertogliati 2015: 99-104). One might even wonder if corporation exclusivism has not provided, in some cases, an incentive for professional diversification and entrepreneurial initiative (Bolla 2000: 28).

Currently, in the PG-OCL, there is limited interest in the possibility thanks to the revision of the LOP in 1992 - of acquiring the status of commoner under certain conditions and upon approval of the assembly. ${ }^{34}$ This is partly due to a lack of knowledge or interest in the activities of the corporations and, partly to a reticence on the part of the older non-commoners to refer to the judgement of the assembly. Today the differences between commoners and non-commoners in terms of privileges and use rights are now practically imperceptible, as FZ reports:

In the present time there is very little difference, but once it was terrible [...]. In my opinion, they are rather matters of pride ... they asked me several times, depending on the presidents [of the PG-OCL] ... to make the request [for admission] ... but then there had been cases of people whose application was rejected, therefore thinking of suffering the same fate I always believed that it was better not to forward it. [...] Some people were even a little irritated by the fact that I had never applied to become one! "Why don't you want to ...? And they told me that more than once!

The same is confirmed by GM:

Like everything now ... the deep blood of commoners that was once there is no longer there, is much more diluted [...]. As he says [FZ], is it a matter of pride, or a question of closeness or distance from a corporation, or not? He married a commoner from Dongio [and] could have asked to become 
a commoner from there [...]. I married a commoner from Olivone and if I wanted, I could be part of it, but I would have to give up the other side [GM is a commoner of Ghirone and Buttino]. ${ }^{35}$

Gender issues are also, at least in part, a contradictory theme. In 1919, in Ticino, female household heads had obtained, by decree of the Cantonal parliament, not only the possibility of representation in corporation assemblies, but also the ability to be elected in their administrations. From 1962 the new LOP extended the right to vote to all commoners of age, including both men and women, since previously it was exercised only by family heads. ${ }^{36}$ The only woman interviewed, however, did not identify major changes in the position of women in the specific case of the PG-OCL, as she argues:

Women in general do not care, perhaps because there is still a mentality and I think it will not change, I don't know - that the corporation is rather a business for men. [...] In many assemblies I was the only woman present! [...] If I can give my opinion, this mentality derives from the time when only the family head took part in the meetings and he was the owner of the use rights. ${ }^{37}$

The developments described in the field of civil rights and citizenship in corporations, rather than being initiatives from the bottom, were imposed by changes in the legal framework at the cantonal level. The debates in relation to the privileges of corporations and census were particularly heated in the nineteenth and early twentieth centuries. Starting in the 1960s, they were reopened and expanded, even calling into question the role of the corporations themselves, while at the same time promoting important and positive changes for these bodies. The corporations and, since its foundation in 1942, the Ticino Patrician Alliance (ALPA), played an active role in these debates and, especially in the last few decades, the debates were animated by the awareness of the participants having to adapt themselves to the changed social and economic political conditions. This process has led today to the full recognition of the role of the corporations by the cantonal authorities, in a social, political and institutional context very different from that in which the Swiss municipal dualism originated. In recent times, apart from a few skirmishes, there has been no pressure on the corporations in Ticino. Conversely, the canton has created privileged financing channels for these entities, fed largely by cantonal funds, in order to promote investment for works and infrastructure of public interest, as well as collaboration with municipalities. We have also seen how the inclusion of new actors such as conservation associations and tourism promotion bodies has led to the creation of platforms for the exchange of skills and for the development of projects in which corporations play an active role. Corporations, municipalities and cantonal services are therefore joined by new stakeholders, and a larger network is thus created, which, despite inevitable conflicts, leads to the management and use of collective resources that is in step with the times. In recent 


\section{Mark Bertogliati}

years, thanks to the joint action of the Ticino Patrician Alliance (cantonal federation of corporations) and the cantonal authorities, efforts have been made to promote the initiative of patricians and collaboration with political municipalities, creating and strengthening the available financial means, recognising the role carried out by these entities as "local antennae" and land managers.

Despite these advances, the population of the Canton of Ticino knows very little about the functioning and characteristics of corporations, just when the need is great due to the ongoing processes of merging municipalities. In this regard, GC underlines the new role acquired by the corporations:

What I see is that the patriziato has acquired more importance ... in the sense of greater recognition, let's say, in comparison to the municipality. [...] The first year I was here [1980] I had the impression that they were two separate entities, each managed independently, and there was rarely any collaboration. Now, however, it's the opposite. ${ }^{38}$

A new strategic study on commoners' organisations was published by cantonal authorities in 2020. It aims to make such corporations "protagonists" at an economic, environmental and cultural level, consequently reinforcing their public recognition and capacity for action, and also an open approach to other actors. The impression is that today these entities, despite their territorial strength (they own about $80 \%$ of the cantonal territory), are almost always "junior partners" visà-vis the Confederation, cantons and municipalities. The strategic study (Franchi 2020: 41) identified three types of project-oriented attitude: (a) traditional, (b) accompanied and (c) innovative planning. Traditional planning is mostly tied to agricultural activity, with a strong link to the land, such as the renewal of alpine building. Accompanying planning is mostly in the forestry sector, which responds to the fulfilment of management tasks by owners, and legal obligations for the conservation of the forest and the maintenance of its functions. Finally, innovative planning "depending on the sensitivity and skills present in the corporation, it can focus on different areas, such as the enhancement of the territory and the historical heritage or on other sectors, such as tourism, adapting to the challenges of the time and the current socio-economic context" 39 .

The increase in public recognition, a project-oriented attitude and increasing the bargaining power of these entities are therefore essential steps in developing their resilience and exploiting their potential in the face of the numerous challenges of society, from urban environments to high mountains where questions arise around a more sustainable use of land and resources, as well as around topics such as climate change and natural hazards. In this context, local resources, also in terms of knowledge, prove to be important tools for facing new challenges.

\section{Decline of the old corporations}

The Vicinia (or Vicinanza) of Olivone, was already made up of lowerorder administrative units before the creation of the patriziato. The "internal 
corporation" of Olivone was an entity that grouped the three degagne of Lavorceno-Marzano, Solario-Sallo and Scona-Petullo-Sommascona - in turn divided into six village communities, each belonging to one hamlet with its own chapel (Meyer 1977: 31, n. 42). These structures remained active even with the establishment of the PG-OCL in the mid-nineteenth century. This "multi-layered structure" is widespread and attested in Leventina (Fransioli 1994: $18 \mathrm{ff}$ ), other regions of Italian speaking Switzerland, and in the neighbouring alpine regions (Broggini 1968: $118 \mathrm{ff}$ ), However, it is an exceptional case in the Blenio Valley. This structure, which was dynamic and flexible depending on needs, involved different plans of participation and coordination in active community life and was reflected in a sense of belonging to different "homelands" (Marca 2001: 31). The administration of the village chapels was one of the fundamental competences of these elementary units (vicinati or local corporations) up to their decline and consequent absorption by the PG-OCL, the local parish or their transformation into recreational societies during the twentieth century (Table 9.6). Each institutional level or body had specific competences. The degagne grouped the vicinati and represented them within the corporation of the "Vicinato interno di Olivone" which still held its annual assembly in the 1930s (Bolla 1935: 54-55). In the ancien régime in the Blenio valley there were other higher-level entities, such as the fagie (three fiscal and electoral circumscriptions) and, of course, the Valley Community which exercised its competence in criminal and procedural law under the direct control of the territorial lordships.

The multi-layered structure described above is an indicator of the political and institutional situation documented at least since the Middle Ages, which was focused on defining competences and delimiting rights and duties in a phase of important socio-economic and political development. In the territories of the "Italian Bailiwicks" controlled by the mountain Cantons Uri, Schwyz and Unterwalden (old members of the Swiss Confederation), this structure could perpetuate itself for a long time, since the process of administrative and political unification and "state-building" was less pronounced than in the Confederate cantons (Würgler 2013). This structure, however, as reported by GC:

(O)ver time has lost its sense, since the small corporations disappeared and in many cases the PG-OCL has taken over from them. [...] This is also because it is already difficult to find people even ready to be involved in the administration of the PG-OCL, let alone the village corporation [...] and so they closed the business. ${ }^{40}$

The small chapels have in most cases been transferred to the parish of Olivone. Not all the village corporations have disappeared, as NB and NS report:

NB: [T] here have been those who did not want to be incorporated definitively in the PG-OCL. Despite being commoners and members of the 


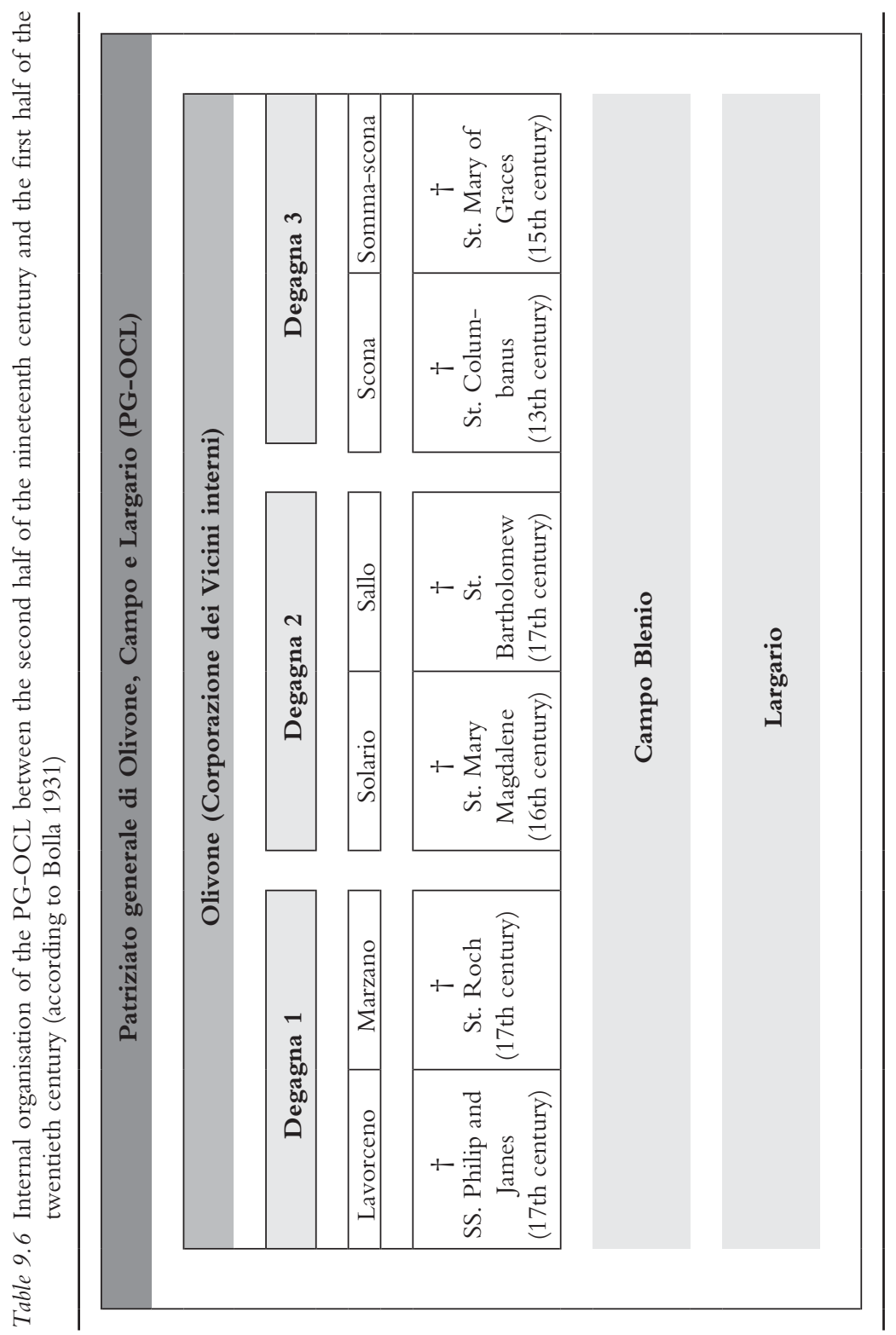


PG-OCL, they still care about having their village corporation. He [NS], for example, is member of the corporation of Marzano-St. Roch and they wanted to keep it. NS: We practically created an association. It's no longer a corporation under public law like the PG-OCL, it's more like a recreational association. ${ }^{41}$

The past existence of a multi-layered structure divided into decentralised village units brought many advantages. They were small and flexible realities, more resilient if we think about today's challenges in land management. They were based on the participation of all the members of the company, which is unthinkable today. Today the management of the territory is entrusted to an increasingly small number of farmers and livestock owners, while the administration of the corporation is based on a mix of voluntary and paid activities which, however, compensate for the commitment that such executive roles entail only to a small extent.

The present structure of the PG-OCL is much less complex than in the past, but this does not mean that the concerns related to generational change and the search for people willing to join the corporation executive disappear. Nowadays, these originally closed corporations often have to deal with the loss of interest, knowledge and experience of the territory by a large part of the population, commoner or not. Participation in the assemblies is perhaps the most eloquent indicator. There seems to have been a drop in interest compared to in the past, when local society had a very compact structure, albeit with inevitable divergences within it, and in which the decisions taken by the assemblies had much more concrete consequences on everyday lives than today, as reported by GC: "Regarding participation, in my opinion it is quite low. Usually about 30 persons participate, and only here in Olivone will there be at least 300 commoners [with voting rights] ..." ${ }^{42}$. The decrease in participation in voting is, however, a general trend in society that is also found at municipal, cantonal and federal levels, starting from the second post-war period. It seems to be even more pronounced within the corporations, however.

The hope for continuity, however, pushes the respondents to look with a certain optimism towards the future of the management of collective resources. So, GC:

In the future I think it [the PG-COL] will be more oriented towards tourism [...] and much more in collaboration with the Municipality. I see it as more open, I don't see a return to closure and exclusivism. I see greater collaboration, while remaining a clearly separate entity but more integrated. I do not see a questioning of its existence, because even if there are not many, there are young and active people. And this in my opinion bodes well. ${ }^{43}$

And finally, NB:

I hope that [the corporation] will continue to exist. But I am confident, because farms declined, but the few resisting are bigger and seem to be 
solid. And then there are young people ensuring continuity and, consequently, the mountain pastures owned by corporations will also be there in the future. Continuity is guaranteed. Here in Olivone, from a cultural point of view there is a particular attachment to agriculture and alpine pastures. $^{44}$

This confidence is also reflected in the proactive attitude of some members of the corporation executive, and of the former president himself, regarding projects such as the National Park (Parc Adula). This was an initiative being studied in a large area straddling the Blenio Valley and the valleys of Graubünden. The project had been put to popular consultation in 2016, but in the end, it was rejected by six municipalities from Graubünden and two municipalities in the Blenio Valley. As NB reports:

I was very favourable to Parc Adula, I was a member of the operational group. [...]. In my opinion it was an opportunity, perhaps not an immediate one, but in the long term it would have brought economic activity for the region. But now ... it was a popular decision. ${ }^{45}$

This initiative saw members of the PG-OCL take sides in favour of a project that was inauspicious to the majority of the population of the concerned regions. At the time of the consultation within the Municipality of Blenio, a deep rift was created between proponents and opponents of the project, with significant political, social and interpersonal implications. This outcome, at least, is an indicator of decision-making processes and the low degree of acceptance of supra-regional projects.

\section{Synthesis}

Considering the case of Olivone as a "society in transition", it is interesting to follow the decline of the "multi-layered structure" of at least medieval origins which lasted until the second half of the twentieth century. In Ticino, these multiple corporate structures are also attested in other regions, but they constitute a particular case in the Blenio Valley. The general trend of commoners' organisations from the Ticino valleys is towards a simplification of structures compared to in the past. At an institutional level, they were very complex bodies. Today, however, it is the bureaucracy and system of relationships with higher-order entities that is more complex. The "internal corporation" of Olivone has disappeared, but at least one village corporation is still alive, even if it has other purposes than governing the commons. Starting from these very deep roots there could be a strategy to revitalise the so-called "commoner spirit", through cultural initiatives and a greater dissemination of their role to the rest of the population. In this sense, an "identity utility" emerges in both the cantonal authorities and the local corporations, but rather as a programme. In recent years this awareness has declined in the PG-OCL due to lack of 
time and the availability of people actively involved in the administration of the corporation. Looking for a balance is not simple in a context where there is no professionalisation of roles and the continuity of activities rests entirely on the passion and availability of a few key people. The members of the corporation executive complain about the growing complexity of the problems and greater bureaucracy in relationships with other entities. There are positive elements, however, identified in the collaboration and dialogue established in recent decades with the municipality, the cantonal services, other corporations and new actors. A service and post-industrial society cannot ignore the collaboration between various actors. The hopes of the interviewees, however, seem to break with reality, due to the growing investments and commitment that the management of these corporations entails and, on the other hand, the low public awareness.

The new legislative and economic promotion tools made available by the canton and the spaces of collaboration between municipalities, corporations and other entities seem to pave the way for the future continuity of corporations in Ticino. This largely counterbalances the lesser autonomy than in the days when the legal bases were more uncertain and conflicts more heated. On the other hand, the whole population's lack of awareness of the role played by these corporations raises different questions.

Economic fragilities can be mitigated with the financial means allocated by the cantonal authorities, and through a more effective collaboration with other entities such as municipalities; however, the institutional and human resources fragilities limiting a proactive and project-oriented aptitude represent even greater challenges.

\subsection{Conclusions: a fragile balance?}

Analysis of the management of collective resources only allows a partial view of the evolution of corporations in the Canton of Ticino in the last two centuries. Understanding the intertwining of identity, institutional structures and the administration of collective goods in the area is not an easy task, and requires an interdisciplinary look. Despite having a financial situation that is deemed solid, the PG-OCL presents different fragilities.

At an economical level, the corporation is faced with major investments for the renewal of alpine structures, forest management and roads, and this also considering the subsidies from the cantonal and federal authorities. The low diversification of activities and lack of important revenues deriving from other activities could be a problem from a long-term perspective.

There are also uncertainties related to the evolution of mountain agriculture and alpiculture, both in the context of agricultural policies and legislative reforms promoted by higher authorities, but also considering the general decrease in farms and livestock owners, and other challenges related to these activities. Problems related to forest transition and, to a certain extent, to climate change and conflicts with new land-use forms pose questions about the 
persistence of traditional forms of alpine management in a very large territory, with characteristics and vocations that are more and more diverse.

In general, in both forest and alpine management there is nowadays a clearer separation between the collective and individual spheres. The internal structure of the corporation is less complex compared to the past. Rationalisation and gains in efficacy and quality standards are positive aspects of this process. However, there is also a loss of ubiquity in land management with the regression or the disappearance of many traditional forms of land use. The consequence, as well as the loss of an interesting ecological mosaic, is found above all in the increase of forest cover, one of the main concerns for both corporation administrators and farmers. One of the respondents suggested that it was like a "lost battle at the start", given the extent and speed of the process.

At an institutional and organisational level, the main concerns lie in the generational change and continuity in corporation executive, the low rate of professionalisation (current members carry out their activity mainly on a voluntary basis) and the involvement of young people, the poor representation of farmers in the corporation bodies and assembly, as well as the lack of a longterm strategic planning.

The identity aspect is also critical, which in our opinion is a general problem for all corporations in the Canton of Ticino. The fact that a large proportion of the population in Ticino (whether members of corporations or not) do not know what these corporations represent is a major concern. The cantonal authorities, as well as the cantonal federation of the corporations, has emphasised in recent years the importance of a wider public recognition of the role of corporations, also considering the increasing process of the municipal merger with the consequent loss of local references. A more effective collaboration with other actors, and especially the municipalities, is invoked by both the corporation administrators and the cantonal authorities. In Spring 2020 a new cantonal strategy was published in this field. Its main goal was to promote the role of corporations in the future.

It is interesting to note that these critical points, on a closer look, also represent opportunities to find new ways of management, internal organisation and involvement. The PG-OCL seems to have made some promising breakthroughs in the management of collective resources. In the past, thanks to this particular attitude to innovation, the PG-OCL earned important awards, which prompted this institution to make sensible investments for the benefit of the entire population. In this regard the main challenges for the Blenio Valley and the PG-OCL are the forest company recently taken over by the reborn valley community which brings together all the local corporations, and the search for a balance between traditional alpine farming and the new land use forms.

The challenges are numerous and very demanding. To face them, the local corporations need greater financial means, bargaining power, and human resources and to retain at the same time a project-oriented aptitude. Such favourable preconditions are not often present in the mountain commoners' 
organisations of the Canton of Ticino. In an uncertain present they have to plan their future, and further support from central authorities is, in our opinion, necessary and desirable.

\section{Notes}

1 Data (2020): www.ti.ch/patriziati.

2 Two grazing areas west of the top of the Sosto, and in Val Carassina, respectively.

3 Political municipalities and "patriziati" were created in the nineteenth century. Previously this distinction did not exist.

4 According to a strategic study published in 2009 (Canonica 2009) by the cantonal authority responsible for supervising these corporations and by the Ticino Patrician Alliance (Cantonal Federation of Patricians). A new strategic study was published in spring 2020 (Franchi 2020).

5 On the concept 'communalisation' see Mathieu 1992: 150 ff., 268 ff. and Mathieu 2011: $35-47$.

6 "Forest transition" is defined later in the chapter.

7 Interview 2, 2018-2-9, 9 February 2018, Representative of the Alpine Associations (SBL, SBVC), Olivone.

8 Ibid.

9 Ibid.

10 Ibid.

11 Interview 3, 2018-6-21, 21 June 2018, Representatives (former president and member of administration) of the PG-OCL corporation, Olivone

12 Ibid.

13 Ibid.

14 Interview 2, 2018-2-9, 9 February 2018, Representative of the Alpine Associations (SBL, SBVC), Olivone.

15 Ibid.

16 Interview 1, 26 January 2018, Former Secretary of the PG-OCL, Olivone.

17 Interview 3, 2018-6-21, 21 June 2018, Representatives (former president and member of administration) of the PG-OCL corporation, Olivone.

18 Ibid.

19 Ibid.

20 Ibid.

21 Ibid.

22 Ibid.

23 Ibid.

24 According to the principle of continuity and sustainability based on the concepts of near-to-nature silviculture and current knowledges of forestry and natural hazards.

25 Bolla 1935: 55.

26 Interview 3, 2018-6-21, 21 June 2018, Representatives (former president and member of administration) of the PG-OCL corporation, Olivone.

27 Ibid.

28 Ibid.

29 Interview 2, 2018-2-9, 9 February 2018, Representative of the Alpine Associations (SBL, SBVC), Olivone.

30 Ibid.

31 The "commoner spirit" can be defined as a tool to mobilise the vital energies of the corporations in guaranteeing their functions, such as the conservation of forests, meadows, pastures, alps and cultural heritage as well as their management for social use, in the interest of the community.

32 Interview 1, 26 January 2018, Former Secretary of the PG-OCL, Olivone. 


\section{Mark Bertogliati}

33 Ibid.

34 This revision significantly eased the constraints on naturalization by definitively sanctioning integration by filiation, marriage and concession on the basis of certain conditions, without distinction of sex and origin (without prejudice to Ticino citizenship).

35 Interview 2, 2018-2-9, 9 February 2018, Representative of the Alpine Associations (SBL, SBVC), Olivone

36 In the Canton of Ticino, by way of comparison, women's suffrage was introduced in 1969. Only two years later, in 1971, women in Switzerland gained the right to vote and to stand as a candidate in federal elections. In the Canton of Graubünden, the right to vote and stand in the Canton and districts was approved in 1972, while only in 1983 did a popular vote extend the right to all municipalities.

37 Interview 1,26 January 2018, Former Secretary of the PG-OCL, Olivone.

38 Ibid.

39 Franchi 2020: 41.

40 Interview 1, 26 January 2018, Former Secretary of the PG-OCL, Olivone.

41 Interview 3, 2018-6-21, 21 June 2018, Representatives (former president and member of administration) of the PG-OCL corporation, Olivone.

42 Interview 1, 26 January 2018, Former Secretary of the PG-OCL, Olivone.

43 Ibid.

44 Interview 3, 2018-6-21, 21 June 2018, Representatives (former president and member of administration) of the PG-OCL corporation, Olivone.

45 Ibid.

\section{References}

A Marca, A. (2001) Acque che portarono: il commercio del legname dal Moesano al lago Maggiore fra 1700 e 1850. Lodrino-Prosito: Jam.

Baer, M. (2000) [1938] Contributo alla conoscenza della terminologia rurale dell'Alta Valle Blenio. Bellinzona: Centro di dialettologia della Svizzera italiana.

Bertogliati, M. (2014) Dai boschi protetti alle foreste di protezione: comunità locali e risorse forestali nella Svizzera italiana (1700-1950). Bellinzona: Casagrande.

Bertogliati, M. (2015) 'Vedere gli alberi e non la foresta: uso e conversazione dei boschi nelle valli dei Grigioni dell'Ottocento: il caso di Soazza', Quaderni grigioni italiani, vol 84, no 2, pp 85-107.

Blatter, M. (2009) 'The Transformation of the Alpine Economy in the Fourteenth to Eighteenth Centuries: Harvesting 'Wild Hay' in the High Mountains', Nomadic Peoples, vol 13, no 2, pp 146-159.

Bloch, M. (1930) 'La Lutte pour l'individualisme agraire dans la France du XVIIIe siècle', Annales d'histoire économique et sociale, vol 2, no 8, pp 511-542.

Bolla, G. (1931) La storia di Olivone. Bellinzona: Edizioni La Scuola.

Bolla, G. (1935) Aspetti di vita montana. Lugano: Tipografia Editrice.

Bolla, S. (2000) 'Dalla patria al pascolo', in Bruni, L. (ed.), Il Patriziato generale di Olivone, Campo e Largario (pp 23-30). Basel - Bellinzona: Sophie und Karl Binding Stiftung, Istituto grafico Casagrande.

Broggini, R. (1968) 'Appunti sul cosiddetto "jus plantandi" nel Canton Ticino e in val Mesolcina', Vox romanica: annales Helvetici explorandis linguis Romanicis destinati, vol 27, pp $216-228$.

Bruni, L. (ed., 2000) Il Patriziato generale di Olivone, Campo e Largario. Un ricco patrimonio ambientale nell' Alta Valle di Blenio fra storia, boschi, alpi, natura, paesaggio. Basel - Bellinzona: Sophie und Karl Binding Stiftung, Istituto grafico Casagrande. 
Caflisch, C. (1950) 'La Val Blenio: caratteri e problemi di una valle del Ticino settentrionale', Geographica Helvetica, vol 5, pp 137-149.

Canonica, M. (2009) Visioni e prospettive per il Patriziato ticinese: studio strategico. Bellinzona: Sezione enti locali - Alleanza patriziale ticinese.

Caroni, P. (1964) Le origini del dualismo comunale svizzero: genesi e sviluppo della legislazione sui comuni promulgata dalla Repubblica elvetica, con speciale riguardo allo sviluppo ticinese. Milano: A. Giuffrè.

Cattaneo, C. (1851) Su la bonificazione del Piano di Magadino: primo rapporto a nome della società promotrice. Lugano: Tipografia della Svizzera italiana.

Ceschi, R. (1975) 'La produzione agricola ticinese alla fine dell'Ottocento', Pro Valle Maggia 1975, pp 112-124.

Ceschi, R. (2009) 'Il patriziato da rigenerare', Rivista patriziale ticinese, vol 3, pp 6-11.

Conto reso (1889) Conto reso del Consiglio di Stato della Repubblica e Cantone Ticino per l'amministrazione dello Stato dal $1^{\circ}$ gennaio al 31 dicembre 1888. Bellinzona: Tipo-litografia cantonale.

Demélas, M.-D. and Vivier N. (eds.) (2003) Les propriétés collectives face aux attaques libérales (1750-1914): Europe occidentale et Amérique latine. Rennes: Presses universitaires de Rennes.

Deplazes, L. (1981) 'Una lite fra due Vicinanze bleniesi all'inizio del XIII secolo: evoluzione del possesso fondiario, comportamenti sociali, uso di violenza e mezzi di pacificazione', Materiali e documenti ticinesi, Serie 3 Blenio, Fasc. 3(1981), Centro di ricerca per la storia e l'onomastica ticinese dell'università di Zurigo, pp 105-129.

Fiorini, S. (2017) 'Campo Blenio' and 'Largario', Historisches Lexikon der Schweiz (HLS), ver. 2017-01-09 and 2017-01-10. Online \#1: https://hls-dhs-dss.ch/it/articles/002049/201 7-01-10/ Online \#2: https://hls-dhs-dss.ch/it/articles/002054/2017-01-09/, accessed on 2019-10-15.

Franchi, V. (2020) Studio strategico sui Patriziati 2020. Bellinzona: Dipartimento delle istituzioni -Sezione degli enti locali.

Fransioli, M. (1994) Il vicinato di Airolo. Gli ordini del 1788. Airolo: Edizione del Patriziato di Airolo.

Guzzi-Heeb, S. (2019) 'Religion, biens communs et organisation de l'espace dans les corporations alpines, XVIIIe-XIXe siècles', Histoire des Alpes, vol 24, pp 105-123.

Head-König, A.-L. (2003) 'Les biens communaux en Suisse aux XVIIIe et XIXe siècles: enjeux et controverses', in Demélas, M.-D. and Vivier N. (eds.), Les propriétés collectives face aux attaques libérales (1750-1914): Europe occidentale et Amérique latine (pp 99-118). Rennes: Presses universitaires de Rennes.

Kaech, A. (1946) 'Die projektierten Wasserkraftwerke Greina-Blenio', Schweizerische Bauzeitung, vol 127/128, no 15-16, pp 177-186, 200-202.

Laurianti, F. (2017) La castanicoltura nelle valli superiori del Ticino tra il Tardo Medioevo e l'inizio dell'epoca contemporane. Analisi storica comparata tra le comunità delle valli Blenio, Leventina, Riviera, Maggia e Lavizzara (Svizzera). Doctoral thesis, Università degli studi di Genova.

Lorenzetti, L., Decorzant, Y. and Head-König, A.-L. (eds.) (2019). Relire l'altitude. La terre et ses usages. Suisse et espaces avoisinants, XIIe-XXIe siècles. Neuchâtel: Éditions Alphil-Presses universitaires suisses.

Mather, A.S. (1992) 'The forest transition', Area, vol 24, no 4, pp 367-379.

Mathieu, J. (1992) Eine Agrargeschichte der inneren Alpen: Graubünden, Tessin, Wallis 15001800. Zürich: Chronos. 


\section{Mark Bertogliati}

Mathieu, J. (2011) 'Gemeinde als sozialer Prozess. Der Freistaat der Drei Bünde 1500-1800', in Hitz, F., Rathgeb, C. and Risi, M. (eds.), Gemeinden und Verfassung. Bündner Politik und Gebietsstruktur gestern, heute, morgen (pp 35-47). Glarus: Südostschweiz Buchverlag.

Merzario, R. (1989) Il capitalismo nelle montagne: strategie famigliari nella prima fase di industrializzazione nel Comasco. Bologna: Il Mulino.

Meyer, K. (1977) Blenio e Leventina: da Barbarossa a Enrico VII: un contributo alla storia del Ticino nel Medioevo. Bellinzona: Salvioni.

Mondada, G. (1959) 'Gli statuti di Olivone del 20 marzo 1474 in una traduzione settecentesca', Estratto da Rivista patriziale ticinese, vol 13, pp 1-32.

Netting, R. (1976) 'What alpine peasants have in common: Observations on communal tenure in a Swiss village', Human Ecology, vol 4, pp 135-146.

Niederer, R. and Bill, M. (2015) Entwicklung der Rohholzpreise und der Lohnkosten in der Forst-wirtschaft: Eine Zeitreihe von 1919/1939 bis 2014. Olten: Fachhochschule Nordwestschweiz, Hochschule für Wirtschaft, ICC.

Ostrom, E. (1990) Governing the Commons. The Evolution of Institutions for Collective Action. Cambridge: Cambridge University Press.

Radkau, J. (2014) The Age of Ecology. New York: Wiley.

Radkau, J. and Schäfer, I. (1987) Holz. Ein Naturstoff in der Technikgeschichte. Reinbek bei Hamburg: Rowohlt.

Società agricola Bleniese (2015) Qualità del paesaggio agricolo della valle di Blenio. Bellinzona: Corzoneso.

Vicari, M. (1985) Alpigiani, pascoli e mandrie. Testimonianze orali raccolte nel Canton Ticino. Trascrizioni e traduzioni dei brani riprodotti nella cassetta. Bellinzona: Ufficio cantonale dei musei.

Würgler, A. (2013) 'Territorialherrschaft', Historisches Lexikon der Schweiz (HLS), ver. 201312-17. Online: https://hls-dhs-dss.ch/de/articles/009927/2013-12-17/, accessed on 2019-10-15.

\section{Other sources}

Dipartimento delle Istituzioni Cantone Ticino (2020) www.ti.ch/patriziati

Federal Statistical Office (1850-2000) Swiss Federal Population Censuses.

Federal Statistical Office (1866-1951) Eidgenössische Viehzählungen = Recensements fédéraux $d u$ bétail Schweiz = Swiss Federal livestock censuses.

Federal Statistical Office (1956-1990) Nutztierbestand der Schweiz (Swiss Federal livestock censuses)

Federal Statistical Office (2019) Stat-tab. www.pxweb.bfs.admin.ch

Ufficio cantonale di statistica (2000-2019) Annuario statistico ticinese. Bellinzona-Giubiasco.

\section{Interviews}

Interview 1, 2018-1-26, 26 January 2018, Former Secretary of the PG-OCL, Olivone, 138 minutes.

Interview 2, 2018-2-9, 9 February 2018, Representative of the Alpine Associations (SBL, SBVC), Olivone, 162 minutes.

Interview 3, 2018-6-21, 21 June 2018, Representatives (former president and member of administration) of the PG-OCL corporation, Olivone, 153 minutes. 
Part III

\section{Synthesis}


$\fallingdotseq$ Taylor \& Francis Taylor \& Francis Group http://taylorandfrancis.com 


\title{
10 Transformation and diversity
}

\author{
Synthesis of the case studies
}

\author{
Tobias Haller, Mark Bertogliati, Karina Liechti, \\ Martin Stuber, François-Xavier Viallon \\ and Rahel Wunderli
}

This chapter reports on a comparative analysis of the five commons regions discussed in the book (Table 10.1) and compares the results of our research to findings from international studies on commons. It focuses on the following issues. Section 10.1 outlines some central points in the history of common property institutions and their diversity. We consider the main changes in politics (development of state and bureaucracy), the economy (industrialisation, change in relative prices for agricultural and forest-related products), and energy ages (from renewable to fossil resources). In Section 10.2 we discuss the similarities and differences of commoners' organisations regarding their history, and consider this in relation to Ostrom's design principles. In Section 10.3 we discuss how political, economic and energy-related changes are currently affecting the five commons regions. On the one hand, relative prices of common-pool resources are still decreasing, but on the other hand, pastures and forests are increasingly valued for their functional contribution to the ecosystem and landscape quality. Among the factors that explain local differences, we emphasise the role of history, the political and economic context, as well as culture and topography. We discuss the balancing strategies designed by commoners to adapt to the market context. Section, 10.4 discusses the balancing act in relation to the state. We emphasise questions of inclusion and exclusion between a commoners' organisation and society, as well as state subsidies and production requirements. In Section 10.5 we discuss the differences between the five cases that arose in the previous chapters. We focus on how vulnerable or resilient these corporations are when dealing with the multiple challenges described earlier. Our central guiding question is: How can commoners' organisations balance market and state by changing their rules of membership and for local institutions, and when being forced to be more inclusive in their governance? The underlying need for institutional change triggers processes of identity building among commoners that include internal and external views on the value of commons. It also questions the role of commoners' organisations in introducing such change. We highlight the importance of finding a balance between a positive 'identity utility', finances and the partly unpaid drudgery of commoning, as these elements have a substantial effect on how resilient commoners' organisations are. Such resilience may be decisive for the 
278 Tobias Haller et al.

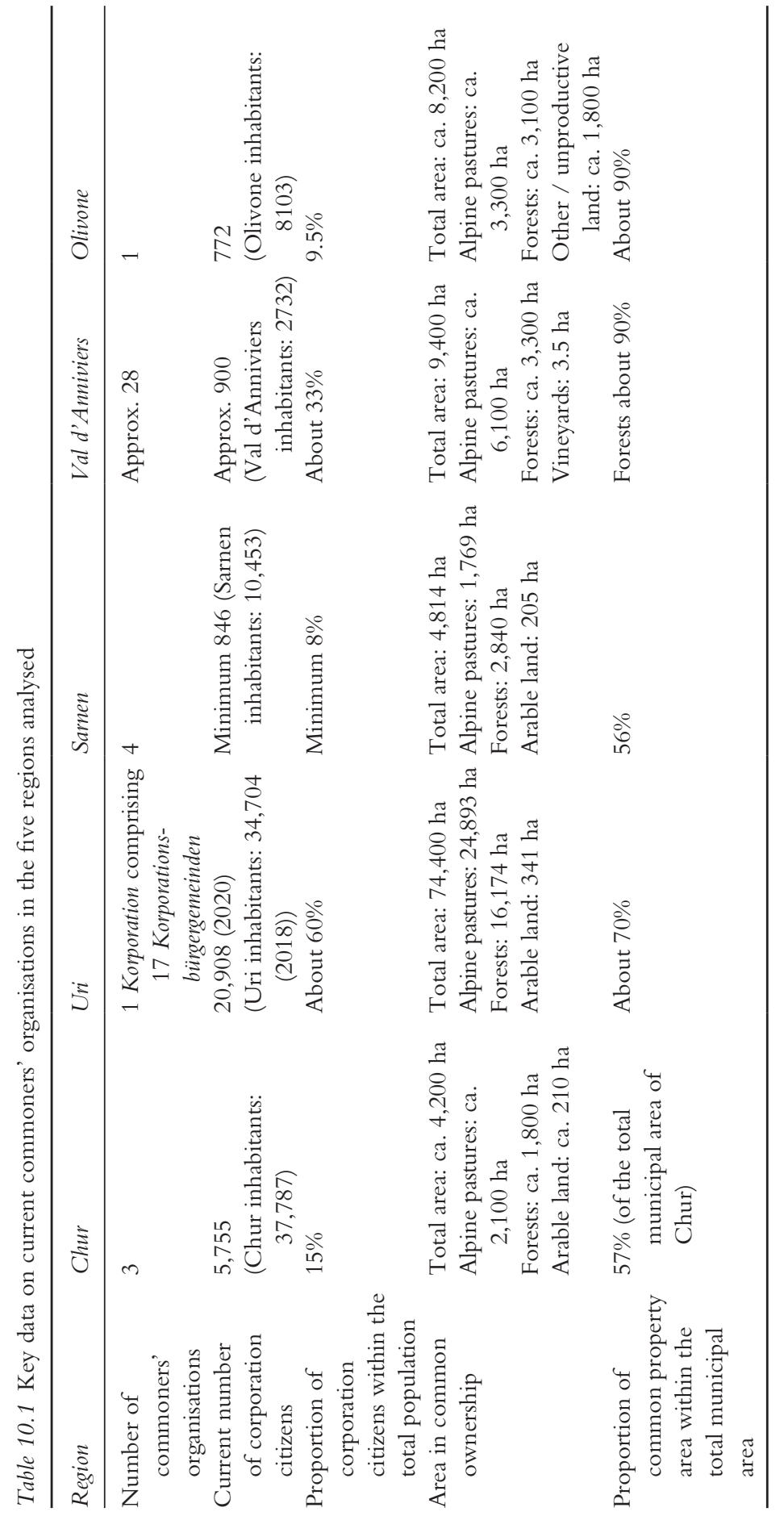


continued maintenance of cultural landscape ecosystems and their biodiversity and landscape qualities. Last but not least, Section 10.6 discusses the different ways the five commoners' organisations have found to create new institutional designs that solve their problems in changing contexts. Departing from the constitutionality approach, which suggests six conditions for participatory bottom-up institution-building processes, we discuss how commoners' organisations fit into the Swiss context. While Swiss institutions secure fundamental democratic and property rights, the market and the state have a huge impact on commoners' organisations, and the latter are greatly dependent on these two external forces. We believe that Switzerland may provide a kind of laboratory for the adaptation and transformation of commoners' organisations as a result of external changes.

\subsection{Common property in the long term: 'robustness' and 'sustainability'}

The core of the commoners' organisations is that they are socially constituted through family in successive generations. This results in long-term continuity in the collective use of local resources, which goes back to the late Middle Ages. Elinor Ostrom captures the intergenerational perspective of these organisations in the 'robustness' described by her famous eight principles. Closely related to this is the long-term concept of 'sustainability', which focuses more on the concrete forms of use. Over the centuries, either explicit or implicit sustainability was implemented towards different goals depending on the changing energy ages (see Chapter 2).

In the 'agrarian society' - until the middle of the nineteenth century - collective forests and pastures were regulated as contested local resources. In all case study regions, the main focus was on the supply of the entitled commoners with these resources. Hintersassen (underprivileged residents), who were allowed to use the collective resources only to a limited extent or not at all, were excluded. It corresponds to the primacy of exclusive needs of the commoners that the resale of products from the common forests (building and firewood, litter, charcoal, etc.) was forbidden, trade with rights of use (cow rights, common litter, etc.) limited to the circle of those entitled and summering rights dependent on the livestock number that could be fed throughout the winter. These regulations did not imply an absence of the market, however. In many places, supra-regional economic interdependencies can be seen from the beginning, which decisively shaped the commoners' economy. The formation of the commoners' organisations in Chur, Sarnen and Uri was determined by the commercialisation of cattle farming, which resulted from intensified cattle trade with the towns in Northern Italy; the economy of the citizens of Chur throughout the Early Modern Period was as much characterised by transit traffic as that of Uri's corporation; migration movements affected the commoners' economy in both Uri (temporary mercenary services) and Olivone (temporary labour migration). The commoners' economy was based everywhere on the 
interplay of collective and private property. This is particularly striking in the Trattweide (common pasture) practiced in all the study regions, which temporarily opens up private areas to collective use in spring and autumn.

In the 'industrial society' - from the middle of the nineteenth century to the middle of the twentieth century - the operational goals for collective forests and pastures mostly shifted from natural supply to financial yield. With the help of scientific principles, technical innovations and a better transport infrastructure, attempts were made to increase productivity and bring it closer to the maximum sustainable yield. Directives were given by the incipient national agricultural, forestry and environmental policy, which involved several levels (legislation, financial support, training). The Schweizerischer Forstverein and the Schweizerischer Alpwirtschaftlicher Verein played important roles as mediators; the latter awarded prizes for exemplary modernised alpine management. The aim was also achieved by draining collective wetlands (Chur, Uri, Sarnen). The limited circle of users was expanded by partially converting rights of use into social open systems of use based only on financial compensation (lease systems). The resulting increase in financial returns from collective resources played an important role in the realisation of social, cultural and infrastructural modernisation in the municipalities, and was particularly prominent in Chur.

The onset of the 'consumption society' - from the middle of the twentieth century - began an economic growth process on the basis of mass imports of crude oil at a comparatively cheap price. The yields achieved both in forestry and alpine farming were increasingly unable to keep up with the rising extraction costs. This fundamental change in relative prices, which was accompanied by other dimensions of change in the 'consumption society', such as mass mobility and mass tourism, had a major impact on the sustainability goals for the collective resources. There was a trend towards polarity of use. On the one hand, further intensification took place through improved transport infrastructure, machine use, fertiliser management and the targeted selection of varieties. Due to the high investment costs, however, intensification was increasingly concentrated on topographically favourable areas (e.g. Chur alps in Arosa). On the other hand, the changed conditions of the 'consumption society' led to the abandonment of land use in less favourably situated areas (e.g. Olivone and Val d'Anniviers), resulting in the reforestation of pastureland. The effect of external political factors on collective resources in this polarised use was ambivalent. The state supports the continuation of alpine farming and forestry through contributions for protection forests and alpine summering, but the state also supports biodiversity, natural forests and protected areas (e.g. mire landscapes). The latter subsidies aim at reducing the intensity of use. The commoners' organisations have already opened themselves to this shift in sustainability goals, from economic production management to the manifold ecosystem services in their forestry, but less so in their alpine economy (e.g. Chur). While these last aspects can be contextualised as within the 'age of ecology' (since the 1970s), the following change, on the other hand, can be fully understood with the logic of the 'consumption age': the expansion to new forms of returns from 
collective resources such as real estate and tourism has largely been completed in most of the case study organisations.

This sequence of the three energy ages, however, which is at the origin of the change in the sustainability goals in collective resources, is only one level of the long-term perspective. Another level involves the social groups and their organisational form as owners of the collective forests and pastures. Their chronological sequence, divided into 'foundation' in the Late Middle Ages, 'consolidation' in the Early Modern Period, 'transformation' in the nineteenth century and 'new roles' in the twentieth century, is not synchronic with that of the energy ages.

Commoners' organisations were and are complex social structures in which the interests of different social classes and milieus have clashed and had to be balanced since their foundations. Far into the period of their 'new role' in the twentieth century, local elites were involved in the management of common goods and used them to secure their social influence. The fact that the commoners' organisations in the nascent federal state were able to maintain their position as public-law institutions alongside the municipalities so well, was due in part to the political weight of these elites in the period of their 'transformation' in the nineteenth century. It is therefore important not to see commoners' organisations per se as the antithesis of rule, that is, as quasi 'bottom-up movements' that opposed a 'top-down style of rule'. Rather, they were organisations that sought to position themselves in the local or regional structures of rule with their own claim to power. This claim can be seen, for example, in the inclusion and exclusion mechanisms with which the commoners' organisations attempted to regulate their own groups of people. The many examples of legal discrimination against non-citizens show that they succeeded in regulating them over a long period of time. However, it is also evident that the boundaries between inclusion and exclusion shifted over the centuries. The graded restrictions of use for Hintersassen during the 'consolidation' period in the Early Modern Period and the long struggle of the Niedergelassenen for political equality in the 'transformation' period in Chur indicates that the line between being entitled and not entitled needs to be further researched.

Even if commoners' organisations are to be understood as entities that integrated different social strata, they were not able to homogenise the differences between these strata. On the contrary, they were strongly influenced by the tensions and conflicts that resulted from this. Livestock owners and non-livestock owners, heavy livestock farmers and small-scale livestock farmers - to name but two examples - had different interests of use. The higher the pressure of use due to population growth or market demands the greater the need for regulation and the more important the decision-making mechanisms. A decisive characteristic of commoners' organisations is their political culture, which shapes the way they deal with internal conflicts and, more generally, the way they shape debates. In our case studies we find references to this debate culture in the Schmähsonntag (reviled Sunday) of Chur, the Halbjahreskilchgang in Sarnen, or in the Landsgemeinde of Uri - forums where the social order could 
be negotiated at least symbolically, and always with precautions to reduce the potential for violence that went hand in hand with social differences.

One of Elinor Ostrom's principles describes the embedding of common property institutions in a setting of different organisations as a prerequisite for their robustness. In fact, such settings can be found in all case studies examined, whether several organisations who constitute a locality like Sarnen or a region as a 'commons landscape' like the Val d'Anniviers or the Valle di Blenio, or an organisation such as the Korporation Uri, which is divided into different suborganisations. Organisational interdependence is therefore an essential element in the history of these organisations. The political map was not stable, especially in the period of their 'foundation' in the Late Middle Ages, but also in the period of 'consolidation' in the Early Modern Period, and demanded constant adaptation. In the course of the 'transformation' period during the nineteenth century, the setting was expanded by the units of the nation state: the Confederation, the cantons and the municipalities. They have since become the politically dominant organisations with which the commoners' organisations have to come to terms. However, even if the dominance of these state actors has made commoner's organisations less influential - for example, in the loss of responsibility for the care of the poor - they have by no means become obsolete, at least as far as the management and regulation of their territory is concerned. As landowners in the cases studied, they have succeeded in positioning themselves as relevant organisations in land policy in the period of their 'new roles' in the twentieth century - for example in the tourist infrastructure of the Val d'Anniviers or on the Chur alps in Arosa. The negotiations between the federal and cantonal representatives and the corporation representatives in Sarnen on mire landscape protection also show that the state authorities are dependent on the commoners' organisations when it comes to enforcing land-use regulations. Political interdependence is and remains for commoners' organisations a balancing act between competition and demarcation on the one hand, and cooperation and complementarity on the other.

\subsection{Common property and power - the theoretical commons literature}

We now discuss the establishment of common property regimes in the five regions analysed and try to establish connections with the theoretical commons literature. In addition to the importance of collective action emphasised by Ostrom, we argue that the power constellations play a key role in the emergence and development of the commons (see Section 10.3). We emphasise the role of local elites and the importance of the market integration of common-pool resources to explain the development of long-standing commoners' organisations.

\section{Rule formalisation processes before 1800}

Institutions for the management of common agricultural lands, alpine pastures and forests were formalised between the thirteenth and the fifteenth centuries 
in all the regions analysed, and included two elements: first, the definition of members (mostly called citizens of the respective commoners' organisations) and the boundaries of the commonly owned areas; and second, the establishment of rules regulating access, timing and members' duties and responsibilities. Apart from common land, farmers often had private plots of arable land as well as meadows used for hay production. In the case of today's Korporation Uri, called the Land Uri before the nineteenth century, the big commoners' organisation managed to install its authority over the many sub-organisations by legitimising their written rules for using resources. Similarly, in the Early Modern Period the commoners of Chur defined ownership and use rules of forests, common fields and pastures that were bought in Arosa. Sarnen, in the canton of Obwalden, saw the development of four commoners' organisations, which adapted their regulations according to different environmental and social settings. In Val d'Anniviers, the ownership and management rested for a long time in the hands of nobles and the church from the Rhone valley downstream. The codification of common property and management rules applying to forests and pastures, as well as village life, occurred in the sixteenth century. At that time, the adoption of the cantonal statutes led to the rapid codification of previously unwritten village rules, together with the increased freedom of commoners in the valley and the six villages. These institutions were also sanctioned by the bishop. Belonging to an autochthonous family in a village was a key condition in order to obtain rights to common pastures and forests, as well as vineyards. Finally, Olivone, located in the Italian-speaking canton of Ticino, enacted a common property union between several villages, established in written documents. These documents indicate that alpine pastures and forests were bought or taken from other communities and noble landlords during the formation of the commoners' organisation. As in the other cases, informal rules of membership and access rights to the common pool resources were codified in later centuries. The current term patriziati, used for the Olivone commoners' organisation, is of very recent history and stems from the nineteenth century. It thus reflects a newer phenomenon, but is a denomination stemming from the existence of century-old collective rights on communal resource.

One could argue that these developments are soundly within Ostrom's design principles, especially those where the transaction cost argument is concerned (clear membership and boundaries, monitoring and graduated sanctions). Most of the cases show that the formalisation and codification of these design principles took place during the Late Middle Ages and the Early Modern Period. In particular, the location of most boundaries was clarified, rules of membership (or citizenship) were defined for a commoners' organisation, and conflict resolution, and mechanisms for monitoring and sanctions were implemented. These changes are not only the outcome of internal local processes. Rather, all cases show that local commoners were embedded in the supra-regional markets around urban centres, especially those in northern Italy. The export of resources related to pastures (cheese and meat), as well as 
timber from these areas, started to increase, and the pressure on common-pool resources rose. Boundaries and related conflict resolution mechanisms therefore had to be codified, as did measures for monitoring and sanctioning. Land Uri is a case in point, where market-related interests (livestock trade) went hand in hand with a kind of conquest of new territory, first of all alpine pastures in neighbouring regions. The interests of the elite had a forceful effect in these developments. Often, but not always, they were also the driving forces behind political self-determination processes, when commoners' organisations tried to become independent of the nobles and the church. Many of these organisations used changes in the structures of rule to progressively buy themselves out of the feudal contract. They became more self-regulated, obtaining titles and communal rights to resources. In places such as Uri, Chur, Val d'Anniviers and Olivone, local elite families would try to take over leadership after breaking away from feudal control. Such processes are of interest, as the bargaining power of these elites was rising. From an internal perspective it is important to say that although the local elite had more power than normal commoners, they were still accountable to the other members of the commoners' organisations and were not able to fully control the resources. This analysis of a negotiated political process as the basis of common property institutions is a central feature of all five commoners' organisations, despite their differences. Further, production was not just for subsistence, but incorporated into emerging market contexts. These elements echo institutional approaches which, in contrast to Ostrom, include the notions of external changes and power of different actors in the model. Such processes were also exacerbated by the generally lesser extent to which the feudal order pushed through in the mountain areas of Switzerland. This, however, did not prevent commoners' organisations from conquering other areas. A case in point is Land Uri, which invaded the Leventina region in the Italian-speaking part of Switzerland towards the end of fifteenth century and controlled the region until the end of the ancien régime. Generally speaking, however, these processes of self-regulation were the historic basis for the creation of diverse resource governance modes, each of them adapted to a specific local ecological, political and economic context, and at the same time - by introducing and adapting resource use institutions (rules and regulations) - they also shaped what we call the cultural landscape ecosystems through several forms of transhumance patterns and the continued use of pastures and forests.

\section{Changes in bargaining power in the nineteenth century}

The liberal-radical spirit brought to Switzerland by the French Revolution favoured a unitary conception of the state and a political system supporting individual rights against pre-existing communitarian rights. Later, the Federal Constitution of 1848 was a compromise between the progressive parts of the country who had won the civil war (Sonderbundskrieg) and the conservative cantons as its losers. As a compromise, the cantons were allowed a high level of 
self-organisation, which in some cases strengthened the position of the commoners' organisations. In some cases - as in Uri - they were given a high level of autonomy. In others, local elites had to include new members and adapt the rules of access to resource areas. Such changes were particularly visible in Chur, and slightly less so for the French-speaking and the Ticino regions. In the canton of Valais for example, municipalities replaced commoners' organisations in their function as local authorities. Consequently, commoners' organisations lost most of their political competencies. While the formal rules still remained intact, informal inclusion and exclusion rules had to be negotiated internally in order not to be undermined from outside.

Regarding the notion of property and forms of organisation, the case studies show that on the eve of major political and economic changes in the nineteenth century, there was a very heterogeneous picture of commoners' organisations. The cases analysed refer to different denominations, such as Bürgergemeinde, Korporation, bourgeoisie or patriziati, with different levels of centralised rules (higher in Uri and Chur), and specific forms of decentralisation in Sarnen, Olivone and Val d'Anniviers. This phase is of interest, as all the commoners' organisations analysed could, in one way or another, maintain the common property institutions of forests and pastures. The legal form on which most of the commoners' organisations are based today, however, stems from the time in which all these areas became part of the cantons of the Swiss Federal State, after 1848. This time is characterised by discussion about whether the commons should be divided into individual ownership or not. In all the cases, the outcome of the debates was the maintenance of the common property institutions and organisations. However, these newly formed commoners' organisations were then excluded from the political governance context, which was dominated by the cantons and the municipalities. There were differences regarding the bargaining power of the commoners' organisations in relation to the power of the state organisations: the commoners' organisations of Uri and Chur seem to have maintained more bargaining power than the ones in the other case studies. This does not mean greater independence, however; on the contrary: the Bürgergemeinde Chur and the Korporation Uri secured their influence precisely through their close ties with the municipality of Chur, respectively with the canton of Uri. Moreover, in the upper valleys of the cantons of Ticino and Valais the number of inhabitants was so low and the villages were so small as to make it often difficult until the end of the nineteenth century to make a real distinction between political communities and commoners' organisations, precisely because these institutions were composed of, and managed by the same families.

\subsection{Balance with the market in a 'glocal' economy}

The transition to the 'consumption society' from the middle of the twentieth century led to a precarious income situation for forests and pastures. Fossil fuel energy reduced the demand for timber and wood charcoal production 
and made these resources rather uninteresting. Agro-industrial processes also substantially reduced relative prices for agriculture, meat and dairy generally. The resources changed from being a source of high value used for capital accumulation, to resources for which the maintenance costs exceeded the pure economic benefits. The economic value of the forests diminished with the decreasing income from wood production, and became primarily linked to forest protection functions, safeguarding infrastructure from avalanches, rock falls and landslides. In the case of alpine pastures, new value arose from agricultural subsidies (see Section 10.4).

Wage labour was undergoing the opposite effect: mountain areas especially need a great deal of physical labour to maintain infrastructure and landscapes for continued production. The value of labour rose because new infrastructure and new industries required a great deal of labour, and offered relatively high prices for wage labour. This also led to changes in the economic value of land and a concentration of production in areas located in the valley bottom that had good infrastructure.

It also restrained the bargaining power of commoners' organisations, which were affected in different ways. Differences in the organisations' bargaining power on the market can be explained by the size of organisations, locations, the different types of resources they own, the use they make of available resources, and the skills they use to engage in new activities. Regarding the latter, commoners' organisations tried to adapt to the decline in market value for natural resources by cross-subsidising resource management with other resources and/or activities.

There were debates in all cases analysed, about how to make production more profitable and more efficient, for example by investing in road networks, which increase the accessibility of alpine pastures and forest areas, and thus reduce labour demand. The high costs of these improvements can only be met with a cross-diversification of income. Cross-diversification means that balance with the market requires successful commoners' organisations to expose some of the competitive common-pool resources to the market to keep other parts of the commons afloat that could not compete with the market otherwise. Such strategies only work, however, if marketable resources are available. For example, an organisation may possess land that is zoned for construction and may be sold or used for real estate, water that can be used for hydropower, or pasture areas that can be used for tourism. These economic uses may also contribute to building new infrastructure that increases the niche profitability of traditional common-pool related resources, such as milk for highly renowned cheese production in the alpine pastures in Arosa, which belong to the commoners' organisation of Chur or differentiated alpine cheese production and direct sales from the pasture in Val d'Anniviers. If these balancing acts are successful, then they may become a new institutional norm alien to normal capitalist profit-making. Such a norm does not increase investments and gains in order to generate profit as such, but to make profit so that the respective sector cross-subsidises the loss-making activities in the commoners' portfolio. Such 
cross-subsidisation allows the whole commons to be saved, including pasture and forests, rather than simply retaining the more profitable areas.

This trend was observed in all the regions studied, but the differences between the cases are of interest, as not all commoners' organisations were affected in the same way. What is certain so far is that some of the organisations owned at least one resource which developed into a considerable source of income during the twentieth century. In the Korporation Uri it was the water bodies that could be used for hydroelectric power and the quarries. The Bürgergemeinde Chur was able to stabilise and expand its financial situation through land ownership in the town and the alps in the tourism hotspot of Arosa. The Freiteil corporation in Sarnen benefited from the fact that its land ownership was mainly located in the valley bottom and in the central settlement area of the town. Other organisations, notably the Patriziato of Olivone, but also some corporations in Sarnen, owned large areas of woodland and pastureland, but their value declined in the course of the twentieth century and it can be assumed that the prices paid for building land in their areas were also lower than in the settlement centres.

Overall, these organisations balanced themselves between maintaining operations in some areas despite high costs, and cross-financing operations through revenue from other areas, such as real estate. The Sarnen case shows a great differentiation between commoners' organisations, ranging from organisations remaining structurally in agriculture to organisations with a large level of economic differentiation. Other commoners' organisations were either too small, or too politically fragmented and disintegrated, to face the bargaining power of the authorities who were implementing and shaping the federal state's policies. In Val d'Anniviers, economic change led to a great reduction in the number of alpine pastures used as commons. The reduction of financial income from wood prompted the merging of forest consortia, and the engagement with new activities outside the forestry sector. In Olivone, the alpine pastures were partly abandoned, especially in the steepest areas.

Adapting to market conditions requires flexible means of administering production and of calculating costs. Managerial expertise and professionalisation are needed. The commoners' organisations coped with this demand to a different degree, which also has an effect on the habitus of respective organisations. For instance, Uri, Chur, forestry in Val d'Anniviers, and some Sarnen corporations show high levels of professionalisation. Unfortunately, there is a mismatch between demands for skilled labour and payment. While marketoriented work is financed through sales or subsidies, the cornerstone of the institutional setting governing the commons - monitoring and sanctioning - is done through labour stemming from the commoners' organisations, and is not always paid accordingly. Here, commoners' organisations face the problem that the maintenance work for their property cannot be fully paid in cash. These workers are mostly elderly and very experienced people and replacing them in the future will be difficult. While there is also a younger generation of commoners (farmers and non-farmers) to supplement the next generation of 
commoners' administrators, ensuring the continuity of the work, and stopping the erosion of the local knowledge of commoners in charge of controlling the maintenance of the common-pool resources are challenges for most commoners' organisations. The Korporation Uri seems to be able to take care of this problem, as it is large, integrated (see Section 10.4) and has options for finding the appropriate people. A further strategy is to combine commoners' suborganisations to achieve synergies in management tasks. The case studies provide examples in forestry, where commoners' organisations get together, create joint organisations, invest collectively and with external partners in alternative heating systems, and cooperate with municipal authorities. Such strategies require new forms of integration with state structures and wider society.

\subsection{Level of integration into society and balancing with the state}

There is currently an impression that the commoners' organisations are at another crossroads of their existence: they have mainly been operating under exclusive membership and with co-ownership of resources in a given area. The corollary is the exclusion of other users, mostly newcomers and immigrants, who live in the same area. As the number of farmers has significantly reduced, however, commoners' organisations are under pressure to revise the basic rules regarding user rights in their organisations. Different strategies for membership are followed in the case studies: basically maintaining the status quo but including the female line (Uri and Sarnen); restricting participation (exclusion) (Val d'Anniviers); and acquiring new members (inclusion) (Chur). In Anniviers, the 2008 municipal merging was accompanied by a vote rejecting the merging of the valley's bourgeoisies. Such rejection may hinder new citizens in the municipality from acquiring the expensive membership of a specific bourgeoisie, as they may not identify with a specific sub-area of the valley.

In Valais, the competency to admit new citizens was transferred from commoners' organisations to municipalities in the 2000s. In Ticino, the admission of new citizens into the patriziati is governed by a cantonal law limiting the margins of manoeuvre for commoners' organisations. The use of the pastoral alpine commons was in most cases opened to non-members in understocking situations. In fact, the pasture and wild hay meadows in the steepest areas had to be used in order to prevent degradation due to the encroachment of shrubs (e.g. Val d'Anniviers, Olivone). The opposite type of management as that from the eighteenth and nineteenth centuries, where operational rules were enforced to exclude outsiders, is now present in some cases, while control is still enforced by commoners' organisations. The prestige attached to commoners' organisations offices has decreased, and/or some functions have been largely reduced to symbolic tasks (e.g. Val d'Anniviers). Many commoners' organisations try to strengthen their collaboration with the municipalities and the cantons, and collaborate with them on specific issues (e.g. district heating with wood, tourism, nature protection, hazards). 
The commoners' organisations have to face, however, the external discourse claiming that a minority is controlling large tracks of land with limited direct benefit to the public. Those commoners' organisations that are able to generate extra benefits, such as in Uri, Chur and partly in Sarnen, therefore try to fulfil public functions by supporting structures and activities from which the entire municipality benefits (e.g. culture, affordable housing). They have thus become aware that they need to redistribute their gains not just among the members, but also among all residents in an area in order to increase social acceptance and political legitimacy. This also includes narratives of the provision of landscape services by the commoners' organisations, which are targeted towards the general public. Commoners' organisations that have little of value to redistribute, except membership, put an emphasis on the preservation of their cultural heritage and of their identity. In Val d'Anniviers for example, commoners' organisations use heritage preservation as a means to increase their visibility to the residents, as well as to encourage tourism. The corporations also thus differ in their identity as regards their importance to the general public. A dominant discourse in all commoners' organisations was that their work, their function and their knowledge was not adequately understood by the general public and that the work they put into maintaining the commons, and providing ecosystem services, is not adequately perceived and esteemed.

The lack of recognition from the general public is also important with regard to the debate concerning state policies and the payment of subsidies. All representatives of commoners' organisations agree that without these subsidies, the governance of the commons could not be upheld. Most of these subsidies are conditional direct payments. For alpine pastures, these are: summer pasturing payments, biodiversity payments, cultural landscape payments, subsidies for infrastructure and so on. For forests, these are: subsidies paid for protective forests and other forest services, subsidies for infrastructure but also for conservation goals and improving the recreational functions. Subsidies reflect the general view of the Federal Government and the cantons, that the Swiss agricultural system cannot survive and fulfil its ecological function and ecosystem services if it is fully exposed to the global market. The state acknowledges the important role of pasture and forest use and management, and provides subsidies for their maintenance. The payment of these subsidies depends upon a set of criteria whose fulfilment is associated with higher costs for alpine producers. These costs are further increased by environmental and nature protection laws which protect ecosystem services and the intrinsic values of nature and landscape. However, all cases analysed showed that subsidies often do not cover all the costs of resource management, which is a great challenge for the managing organisations, and requires, among other things, the cross-subsidising of resource use (see Section 10.3).

In the ongoing debate about agricultural policy and subsidies, there is a narrative about farming households 'getting subsidies while at the same time polluting the environment', which is criticised by the commoners in all our cases. Environmentalists stress that today's farming in the alpine areas also has much 
more environmental impact than in former times. Roads in the alpine area and their negative ecological impact are particularly hotly debated. Such a narrative is challenged by commoners' organisations, which develop counter-narratives that place an emphasis on the amount of work involved in the maintenance of cultural landscape ecosystems, economic constraints, their work for the general public, their high degree of local knowledge, as well as their contribution to sustainable development. While the state and other actors outline the importance of regulating the use of commons, commoners' organisations perceive local practices, local knowledge, and their long-term perspective, as solutions for resource-management-related problems.

In several commoners' organisations we heard the complaint that external experts had not been knowledgeable about the practical heterogeneous cultural landscape contexts, and that they had given little consideration to the ecological conditions created by the cultural transformations in these landscapes over centuries. In the Korporation Uri, herders hired by the corporation complain that scientists assessing biodiversity payments do not consider topography in relation to exposition, and its impact on biodiversity. Further, it was mentioned that the regulations for summering contributions do not address the issue that the number of animals with access to the pastures should be lowered due to the higher weight of the new cow breeds. Similarly, in Sarnen, representatives of commoners' organisations criticised the views of environmental experts as regards measures for the protection of mire landscapes. The commoners' organisations therefore need, on the one hand, to engage in the discourses of the 'era of ecology' and to integrate demands from the state and society. On the other hand, they want to maintain their legally secured independence of ownership and management and use of their common property. Finally, commoners' organisations are in a weaker position and thus have to perform a balancing act when it comes to the economic power of the state. Diverse and often conflicting types of local and external environmental knowledge and exposure to the way environmental laws are implemented are a great challenge for them.

\subsection{Commoners' organisations and their resilience}

This leads us to the issue of the resilience of commoners' organisations in their capacity to continue using the commons despite significant social, economic and political changes. This section discusses the capacity of commoners' organisations to recover from stress.

The commoners' organisations under analysis have shown remarkable robustness as institutional settings. Despite major changes and the various challenges over the centuries, they have all maintained the basic commoners organisational structure, and related institutional major settings. According to Ostrom's design principles, especially those about reducing transaction costs (such as boundary/membership as well as monitoring and sanctioning), commoners' organisations seem to be robust at the moment. Ostrom's analysis in 
Governing the Commons (1990), however, lacks a view of the economic and ecological resilience that these cases entail (see Chapter 4). While the institutional setting seems to be robust, there are a number of issues. First, the commoners' organisations have an increasing number of tasks to perform, criteria to meet, and management responsibilities to bear. This increase in workload relates to the growing complexity of the context within which commoners' organisations operate. Chur, Uri, some of the Sarnen commoners' organisations and forestry activities in Anniviers have taken steps to professionalise these tasks, however, much of the work connected to smaller commoners' organisations is done either on a voluntary or a partly unpaid labour basis. This particularly involves the supervision tasks.

A second issue - as outlined above - is economic resilience. Commoners' organisations that are not able to diversify their activities and do not have much bargaining power vis-à-vis municipalities, cantons and the state face greater hardship in meeting out-of-pocket expenditure for vital issues such as those previously known as miscellaneous expenses. This means that these organisations have few, or no, reserves to meet basic investments such as road maintenance, repairing cheese-making facilities, other infrastructure maintenance, the additional costs of forestry services or additional claims related to environmental legislation. This economic vulnerability adds to generational vulnerability and threatens to undermine resilience in maintaining forests and pastures. Under such conditions, the important investments for economic diversification that would be required to reduce vulnerability and that could reinforce resilience in these domains are also limited. Current discussions in the cases considered are less about new ideas than how to cope with current problems, which also reduces the capacity to innovate.

Third, this leads us to the issue of organisational vulnerability, which has been hinted at already regarding the generational problem. In cases where the commoners' organisation still has political weight and power - such as the Korporation Uri - or where it offers social integration and an opportunity to gain professional expertise, young people are interested in taking on responsibilities or engaging in new activities. In other cases analysed, such as Olivone and Val d'Anniviers, interest is dwindling. This leads to another issue that was alluded to in Chapter 4: local actors always had an interest - from a local perspective perceived as an emotional 'utility' - in maintaining the cultural landscape ecosystem, because this was their livelihood, and the workload (drudgery) did not exceed the subsistence-related utility function. This utility function also applied to elites within the commoners' organisations. These elites had to be accountable and also had to see that non-commoners received a share of the common-pool resources in order to remain in power. Later, with the changing relative prices for common pool resources and related reductions in income, the maintenance became more and more important and exceeded the utility. In all cases, however, especially in the discussions with the monitoring personnel of the commoners' organisations, there was a sense of positive utility in maintaining the landscape. Maintaining the cultural landscape gave a 
sense of pride and identity, perhaps as a reaction to criticism from outsiders. In this sense, as many anthropologists teach, it is precisely alterity that feeds identity. The representatives interviewed also emphasised the importance of perpetuating the work of their ancestors, and remembering what life was like for previous generations. We thus speak of a very strong 'identity utility', which until now was able to provide a counterbalance to the economic drudgery of working the commons. With the controversial debates on agricultural subsidies mentioned above, the perceived drudgery of the work may exceed the positive utility function, and the balance between these dimensions may be lost. In other words, all the unpaid extra work put into the maintenance of the cultural landscape ecosystem would be undermined, and the resilience capacity of the cultural landscape ecosystem would be at risk.

We have tried to show in a qualitative sense where the different commoners' organisations stand in terms of their ability to be economically resilient and less vulnerable. This relates to the bargaining power that they perceived to have in order to be able to decide on their own and being less pressured by state and canton as well as by market actors and conditions. This ability buffers economically difficult situations of commoners'organisations and maintains the possibility to retain their say in decisions. What we propose here is not a ranking but a relational positioning in a matrix of resilience and bargaining power. It indicates that Uri and Chur, as well as three Sarnen corporations, have better potential to cross-subsidise pastures and forests via other revenues, and that they also have more power to make decisions. This, we argue, is less possible in other commoners' organisations, including one other rural corporation in Sarnen, as well as in Olivone and Val d'Anniviers (see Figure 10.1).

In order to contextualise the strategies of individual commoners' organisations regarding their common property institutions and their respective resilience as discussed, we propose to use an adapted version of the Ensminger model (see Chapter 4) which helps to show basic trends in the interrelationships between external factors in the realms of policy, economy and society, with the internal contexts that form a kind of action arena of interacting elements. Changing relative prizes related to changing external variables leads to changes and different meanings of the value of the commons (agricultural land, pastures and forests). These changes then effect the internal system of the corporations, affecting their bargaining power, their organisation, the institutions they select and the ideology they use to legitimise their actions and institutional choices. These factors, in turn, also shape the meaning that is attributed to external changes (via relative prizes).

Figure 10.2, which is generalised based on the Sarnen case study, tries to capture the external changes leading to a change of relative prizes: whereas the economic value of common-pool resources such as pastures and forests and their related products is decreasing, at the same time the importance of ecosystem and landscape services, whose maintenance is partly compensated, is rising. This affects local bargaining power and, for instance, increases issues in the legitimacy of the commoners' organisations' property ownership under 


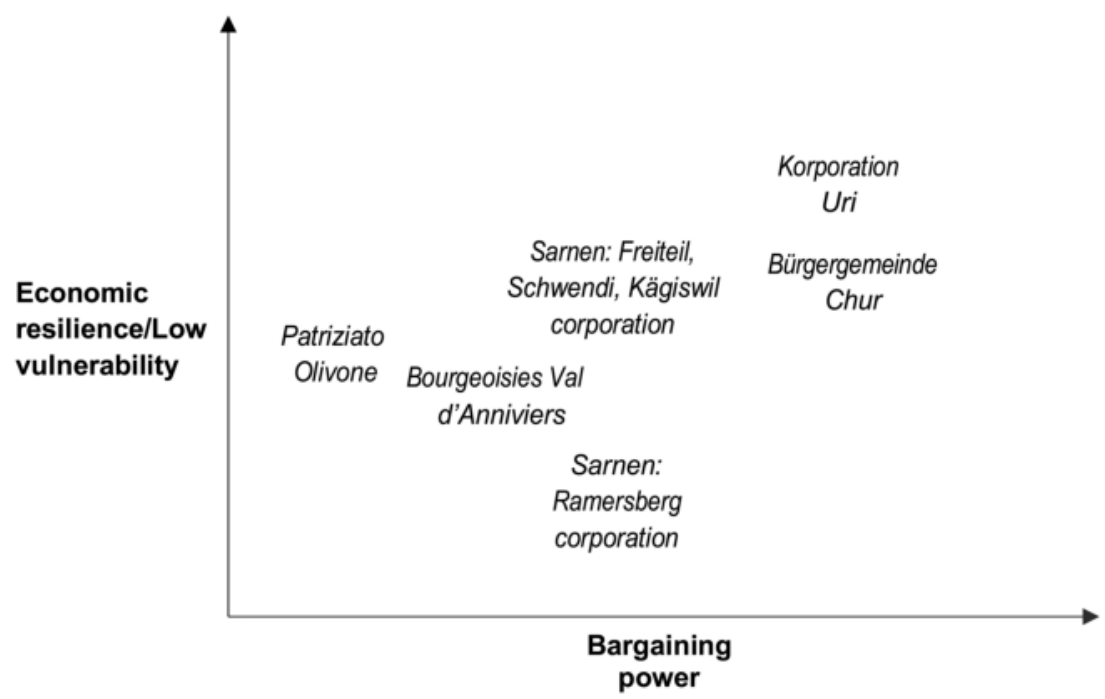

Figure 10.1 Matrix economic resilience/vulnerability and bargaining power in Chur, Uri, Sarnen, Val d'Anniviers and Olivone (source: case studies by Wunderli, Stuber, Liechti, Viallon, Bertogliati compiled by Haller for this volume, rights with authors).

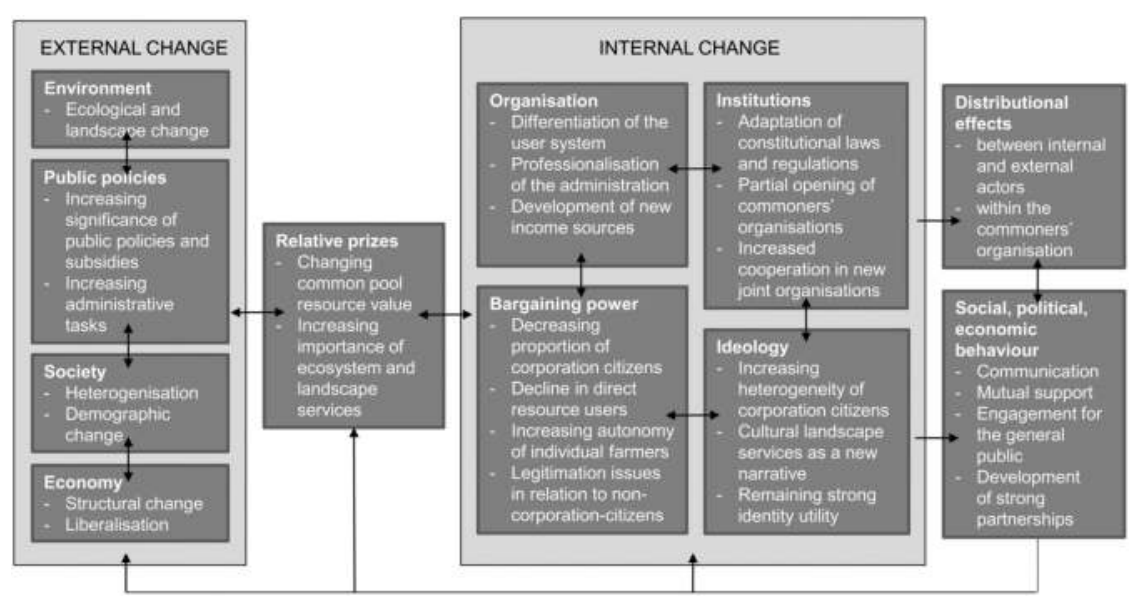

Figure 10.2 Institutional change in Swiss commoners' organisations in recent decades (generalised based on the Sarnen case study and on an adapted model by Ensminger 1992, revised by Haller 2019, see Chapter 4). 
a decreased proportion of commoners. This and other internal processes may lead to the adaptation of the organisation of the corporation and its institutions, among other things related to the implementation of public policies (e.g. pasture use regulations), but also regarding internal corporation structures and citizenship regulations. It also may lead to a change of economic practices, such as the development of new income sources and the internal subsidising of less profitable income sources such as forestry and alpine pastures use. Such institutional changes are ideologically legitimated with narratives on maintaining the cultural landscape ecosystem as such, and strengthened with the discourse of a unifying identity among an increasing heterogeneity of corporation citizens. This may lead to new forms of redistribution of gain and of collective action towards more cooperation between commoners' organisations and with the non-commoners' world. However, these are just broad trends and the case studies show clearly that commoners' organisations differ in their constellations and thus have higher or lower power-specific options to cope with changes in relative prices, and are thus more or less resilient.

\subsection{Conclusions: Switzerland as a laboratory for the adaptation of commoners' organisations to external changes and for their transformation}

What are the lessons from the commoners' organisations that try to address the challenges noted above, and what is the contribution of the Swiss cases to the general discussion on grassroot strategies to address such challenges? One important feature of the Swiss commoners' organisations is that the communal property is guaranteed by federal law and that commoners may decide what to do with this communal property as long as legislative requirements and environmental standards are met. We found a series of social and integrational innovations which make the Swiss commons case a type of laboratory. In a context where property rights are secured and the state provides subsidies to contribute to the financial burden of commons management, local actors may adopt a panoply of local strategies to maintain and develop the commons. The challenge is, having survived the political pressures of the Helvetic Republic, how the commoners' organisations survive the pressure from the market and the state's rules after major changes in the twentieth and the twenty-first centuries with changed relative prices, new energy ages and industrial and post-industrial transformations. Our observations show that a successful implementation of strategies to maintain the commons depends on the involvement of all local actors, so as to create a sense of ownership of the rules. This sense of ownership also helps to lower the vulnerability of commoners' organisations, and strengthens their resilience. The Swiss cases show the strategies developed and tested in this political-economic and ecological lab of guaranteed property rights for these groups also being exposed to certain market conditions. We will outline several strategic elements of this lab and how it relates to bottomup institution building processes in other parts of the world. 
Elements of the 'Swiss commons lab' include the following: first, the issue of income diversification is central and so is the use of the profits generated to maintain other fields of action. Such balancing with the market by crosssubsidising resource management lowers vulnerability and increases the resilience of commoners' organisations. Land for construction and other resources with high long-term yielding relative prices (real estate, hydropower etc.), and engagement with new activities, helps to increase internal revenues. These revenues are used to cross-subsidise the communal forests and pastures that make small profits, or even losses. The commoners' organisations that manage to do this have proven to be more resilient in other areas of resource management. This actually follows a relatively traditional peasant economic minimax strategy and the focus on safe-guarding subsistence features in general that is now also extended to broader aspects of the concerned groups and of society at large. Consequently, the economic resilience of resource management increases and their vulnerability decreases. There is a potential gap, however, between these new means of generating income and the traditional functions of commoners' organisations as custodians of the land.

The second lab element detected is the use of synergies. As outlined above, this is a critical issue and it not only has positive aspects, but it became clear that economies of scale (or reducing drudgery using positive aspects of economy of scale) is an important strategy used by several of the commoners' organisations, especially in forestry management and administration. There is also a need to develop this fusion process in organic ways so that partners with different bargaining power do not feel left out. The commoners' organisations of Sarnen (with the establishment of a common forest consortium for all four corporations) and Val d'Anniviers are good examples of such a process of fusion processes that took time. They show that this needs to be done with care and has to incorporate all interest groups in order to achieve a sense of ownership over this change process. The same process (creation of a forest consortium representing all the valley corporations) is also underway in the Blenio valley, but it is still early to evaluate the results.

A third element is how to deal in a new way with the inclusion/exclusion issues: there are a number of innovations here due to allowing common resources to non-members and to enlarging membership by reducing the financial demands and/or to changing membership regulations (as by the commoners' organisation in Chur, for example). Not all commoners' organisations are following this strategy, however, and are maintaining exclusivity because they fear, among other things, a loss of organisational identity. This reaction was particularly visible in the municipal merging in Val d'Anniviers (see Section 10.3). In other cases, such as in the canton of Ticino, it is the state that has set specific limits to exclusivism following debates during the twentieth century that have even called the existence of the patriziati into question.

The fourth element involved what all commoners' organisations try to do to create a symbolic bond with their members, and to show that they are important for the general public. This is done by trying to maintain good relationships 
with both cantonal/municipal representatives and with the general public. In Anniviers, bonding occurs through the organisation of aperitifs for new citizens, tourists interested in local traditions, and religious feasts. In all cases, trying to show the importance of commoners' organisations also on a symbolic level is a key and important strategy in the 'Swiss commons lab', in which the currency of authentic locality is central (reunions, rituals etc.). The recovery and improvement of these aspects is vital, especially where the value of resources and the bargaining power of corporations is low. This suggests that storytelling may also become an important strategic tool for commoners' organisations.

This leads to the fifth element, which involves exposing the commoners' identity discourse in a positive way in order not to be trapped by the perceived negative discursive labelling. Here the wealthier organisations can use their financial capital to show their commitment to wider society and help municipalities and cantons to fulfil their tasks. One central aspect in this respect is the use of ecological symbols by commoners' organisations, such as claiming that protecting nature means maintaining their integral cultural landscape through their sustainable use of pastures and forests. This leads to contestation with other actors over the hegemonic meaning of ecologically sound management and the commoners' organisations' ecological and social responsibility. An innovation in this sphere is to present the commoners' organisations as being those still managing the cultural landscape ecosystem for the common good (and not for the commoners' good only). This is also a part of the 'Swiss commons lab' where we see differences between the commoners' organisations that are able to publicly state this. Some of them are more capable of successfully maintaining a self-image and self-labelling, such as Uri, Chur and Sarnen, but the others, however, perform less successfully. In Val d'Anniviers, wine-making and drinking traditions are important, but this rests on a more cultural and symbolic capital of authentic belonging, rather than maintaining the cultural landscape for economic (tourism) and ecological benefits for the common good.

There is a sixth laboratory element generally dealing with how to collaborate with municipalities, cantonal administration and environmental NGOs, and on how to act in reciprocity with these organisations. Sharing tasks of governance and the management of duties on different levels of subsidiarity is a central element (also depending on bargaining power). When positioning themselves as reliable partners in maintaining both ecosystem and landscape services and in societal matters, commoners' organisations contribute to sustainable development by maintaining a dynamic diversity of structures and providing locally adapted and grounded means of dealing with today's ecological and societal challenges. Such strategic cooperation between commoners' organisations and other actors includes innovations for alternative energy provision (e.g. district heating with wood) and tourism infrastructure (e.g. ski-lifts, restaurants).

But the 'Swiss commons lab' also shows the diverse adaptations to the diverse localities that stem from a different history, topography and natural endowment. This can be considered a strength of the 'Swiss commons lab', meaning the capacity to be able to also find decentralised separate solutions within 
a single federal legal framework. A wide range of adaptation strategies is also interesting from an ecological point of view in order to find sustainability pathways in the context of global changes, which particularly affect the alpine area.

All these elements echo to a certain degree the lessons learned from the Global South about gaining a sense of ownership in the bottom-up institutionbuilding processes (constitutionality). This approach, which stems from the empirical analysis of rare cases of positive commons governance from below, shows that these new institutions could be built only because the process was perceived by all actors as fair and really participatory. The six elements of constitutionality that could be detected from several cases on fisheries, forestry and pasture management included: (1) a local perceived need to change, (2) processes that level power asymmetries, (3) pre-existing institutions, (4) external catalysing agents for fair platforms, (5) innovation and social learning incorporating local ecological knowledge, and (6) state acknowledgment. In the 'Swiss commons lab' context, as heterogeneous as the cases are, we can however still detect communalities related to the six elements of constitutionality: the first condition is partially met, as actors are very heterogeneous in their ideas about whether and how to change the institutional setting. In $\mathrm{Val}$ d'Anniviers, as an example, most representatives do not support changes to the commoners' organisation they belong to. Rather, they conceive themselves as guardians of the past, of traditions, or heritage. In Sarnen, in contrast, the awareness that change is necessary is relatively high. Element (2), processes that level power asymmetries, is crucial, as there are options to do so via the Swiss political system, but there is a need to pay attention to dynamics inside the commoners' organisations, as well as to their relationships with the outside world. Depending on the bargaining power of commoners' organisations related to municipalities and the canton, this element is not present in all the cases. Element (3), pre-existing institutions, is really a strong case to build on, as perhaps the greatest capital of Swiss commoners' organisations is really the pre-existing institutions, while for (4), external catalysing agents, there are several mediating organisations (see Chapter 3) but this, so we argue, still needs to be worked on, especially in relation to commoners' organisations that have less bargaining power and are less able to be competitive as regards the outside world. Element (5), innovation and social learning, still needs to be improved, as many cases show the perception that local actors do not feel that their local ecological knowledge is really respected when it comes to the discussion of interpreting ecologic processes. Many representatives of commoners' organisations thus wish that local ecological knowledge was more incorporated in the drafting of the rules of subsidies. But there is also a need for more openness on the part of the commoners' organisations to the results of the environmental sciences and to the shift from production goals to environmental goals. Element (6), state acknowledgement, finally, is very strong but also paradoxically very weak in Switzerland. The strong element comes from guaranteed property rights, as well as the level of financial support provided; however, the involvement of the commoners' organisations as owners of between about 
60 and $90 \%$ of the respective alpine pastures and forests (in our case studies) in a rule-defining process from the beginning is not guaranteed. The way that commoners' organisations balance themselves with the market and with the state particularly needs to be examined, as well as the heterogeneity of the path dependencies of these organisations and their common property institutions.

Commoners' organisations with a strong social structure and cohesion are vital for the sustainable use of natural resources and the provision of ecosystem and landscape services. The advantages of such systems are: a long-term perspective due to a focus on maintaining resources, and not on making a profit, and on keeping the resource base for future generations; fast reactivity/responsiveness due to straightforward small structures and organisational freedom, while at the same time acting as a brake against too fast and too fundamental changes; closeness to the everyday life of the users due to grounded regulations; and strong identification potential and sense of place and ownership due to long-standing entities. The large areas of land managed by commoners' organisations could thus be an asset in the implementation of the sustainable development goals (SDGs) in Switzerland. Granting these organisations a more prominent and participatory role in the shaping of the SDGs would offer solutions accepted by all parties, tailored to the region of implementation, and likely to be implemented successfully.

There is still a need for action, because the balance with market and state might easily be lost if commoners' organisations are not strengthened, and if they lose their bargaining power. While the level of self-determination is a key factor in crafting and adapting rules, corporations each struggle in their own way to keep the balance between utility of identity (a strong feeling of being important actors shaping the cultural landscape) on the one hand, and both the work and the financial drudgery of maintaining the common property of cultural landscape ecosystems on the other hand. The crucial element in this balance is whether the commoners still value their commons and whether the farming community is still powerful enough. The Swiss case shows clearly that locally adapted principles are important even within a spatially small context, and that creating platforms so that these can be discussed and implemented in a participatory way seems to be key. This would, for example, involve a broad discussion on how the future of subsidies should be institutionally shaped, how societal recognition can be given to the commoners' organisations and how duties should be distributed among them. Finally, we propose that the Swiss policy implementing the Sustainable Development Goals (for example SDGs such as Numbers 15 (life on land), 13 (climate action), 7 (affordable and clean energy), 6 (clean water and sanitation) and 17 (partnerships)) should recognise the biggest landowners. These are the commoners' organisations, managing large parts of the country's cultural landscape ecosystems, with their biodiversity in pastures and forests and climate resilience capacities and ecosystem services. In this context, it would be of interest to put federal and cantonal governments in touch with the respective commoners' organisations and also with the Swiss association of the commoners' organisations. 
These are central elements that go beyond the Swiss case, and are also global issues. The Swiss case could show that protecting common property rights and being able to define one's own local institutions does not suffice in a neo-liberal economic world. Commoner's organisations' capacity to balance is also dependent on their bargaining power in relation to other actors such as the state and its actors, which might support but also challenge the way ecological functions in the cultural landscapes are accepted. Thus, our work shows that the commoners' organisations need common property rights to be respected, but that they also need to increase their bargaining power to be acceptable players in the negotiation process enabling them to define their views on resource governance. They need to balance changes in the value of common-pool resources, create the right mix of maintaining a resource base for the future but also creating a fair amount of profit and protecting it from degradation. Using the SDGs and critically reflecting on their national implementation might be an option, not only for Swiss commons but for many commoners' organisations and groups in the Global South.

\section{References}

Ensminger, J. (1992) Making a Market. The Institutional Transformation of an African Society. Cambridge: Cambridge University Press.

Haller, T. (2019) 'Towards a new institutional political ecology: How to marry external effects, institutional change and the role of power and ideology in commons studies', in Haller, T., Breu, T., de Moor, T., Rohr, C., and Znoj, H. (eds), The Commons in a Glocal World: Global Connections and Local Responses (pp 90-120). London: Routledge.

Ostrom, E. (1990) Governing the Commons. The Evolution of Institutions for Collective Action. Cambridge: Cambridge University Press. 
$\fallingdotseq$ Taylor \& Francis Taylor \& Francis Group http://taylorandfrancis.com 


\section{Index}

Page numbers in "italic" indicate a figure and page numbers in "bold" indicate a table.

Ackerbürgerstadt (agrarian city) 9, 130

adaptation 4, 5, 7, 10, 45-47, 154, 166, 167, 170, 171, 182-185, 208-215, 282, 294-299

adaptive capacity 54

agrarian-industrial knowledge society 27

agrarian society $8,20,25,26,279$;

contested local resources 25-27;

industrial society 27 ; natural products

121-123

agricultural production 217-219

agriculture: changes in 72-73, 241-247,

252; competition and 78

Allmende (common lands) 130-139

Allmendgenossenschaft 9

allodiateurs or consorts 192

alp cellar 248

Alpgenossenschaften (alpine cooperations, alpine cooperatives, alpine associations)

23, 71, 77, 95, 151, 240, 245, 246, 248

alpine hut, inauguration of 175

alpine pastures 219; and forests, utilisation rights for 71; use regulations 164-165

alps, the, management of 241-252

Alps Commission 107

alps improvement movement 27

Alpvögte (alpine bailiffs) 76, 95, 95

Altdorf 7

ancien régime 17, 69; in the Blenio valley

265; Canton of Ticino and 239; fall of

26 ; inequality of the 22

ancient collective servitudes 238

ancient families 21

Anniviers' bourgeoisies 195; forest consortium 208-211

annual assembly (rogations) of commoners' organisations in Anniviers 202 annual reports, front pages of 91

Armengut (property for the poor) 22, 118

Arosa 133-138, 135

Ayer 201, 205

Balancing on an Alp (Netting) ix, 2

Bannordnung (banning order) of Flüelen 73

bargaining power 168-176; internal corporation structures and 174-176

barns, professionalization in 219

Beggars' Statutes (1644) 21

Beisassen 152

Betriebsplan (2004) 129

Bezirk Uri (district of Uri) 69

Binding Foundation Prize 247

biodiversity ix, 1, 52, 89, 101, 137, 166, 215, 235, 249-251, 279, 280, 290

Bishops, emancipation from the 110-111

Blenio Valley 236, 265, 268; political community of 237 ; see also Ticino valleys

book, overview of the 8-12

border disputes $71-72$

bourgeoisies xi, 7, 8, 10, 17, 55, 189, 192, 194-208, 214, 220Bundi, Simon 108

Bürgergemeinde (Corporation of Citizens) 9 , 17, 105; role of 117-121

Burgergemeinde Bern 25

Bürgergemeinde Chur (Canton Grisons) 9, 105-146, 286, 288; map of 107, 134

Bürgernutzen (citizens' benefit) 99 , 124-127, 140

Cancian, F. 46

Cantonal constitution (1888) 102n23; (1984) 102n24

Cantonal Execution Ordinance (1877) 153 
cantonal law (LOP), in the Canton of

Ticino 260-264

canton of Bern 21

canton of Grisons 105, 108, 110-111, 121,

137; Lukmanier Pass 234

canton of Obwalden, spatial characteristics of $148-151$

canton of Ticino 234, 238, 295; cantonal law (LOP) 260-264; changes in agriculture in 241-247

canton of Uri, geography of 64

canton of Valais ix, 199, 208, 285

Carassina valley 234-236, 238, 271n2

case studies, comparative summary of 11-12

Cattaneo, Carlo 234

cattle husbandry 72

Chayanov, Alexander 46; model 47, 55

Christ, Ludwig 114

Chur 9, 105-107; common grazing in 123, 132; forest economy of 121-130; Schmähsonntag (reviled Sunday) in 112114, 281; usable agricultural land in 131; view of 113; wood processing in 127

Chur Allmende 130-133

Chur Alpine pastures 106-107, 109

Chur alps at Arosa 133-138

Chur citizenry, emancipation of the 110-111

Chur Farmer's Cooperative 106, 137

citizen lineages 157

Citizens' Council 105, 108, 118, 120, 125,129

Citizenship 17: claiming 21; granting 130; restrictive 79

civic community (Bürgergemeinde) 169, $186 n 40$

'classical' commons 1

climate change 264, 269

club goods 5

collective action 5; frameworks of 4

collectively owned property 21 ; consolidation of 21-22

collective management of resources 10 , uses of 279

collective ownership 1, 5, 238

collective rights $73,234,283$

collective servitudes 238,250

collective systems 54

collective utilisation rights, recognition for 19

commoners: economy 279-280; identity utility $8,12,55,268,277,292$; and non-commoners conflicts 262 commoners' organisations 7; Anniviers' 226-230; approaches to interactions 35-36; bargaining power and 11, 227, 285, 286, 292, 299; and common property 279-282; and complementarity 39; co-ownership between 235, 236, 243, 247; cultural heritage preservation and 289; economic difficulties of 291-292; embeddedness of 36; emotional 'utility' in 291; heterogeneity of 35; history of 19-21; inclusion/ exclusion issues and 295; infusion and 38-39; institutional change in 293; integration into society and 288-290; interactions between 36; key data on current 278 ; as a laboratory 294-299; land ownership 39; and legal competencies of 10 ; and management of Alpine natural resources 35; and the modalities of interaction with the state 37-40, 40; and modes of interaction with the state 8, 19; Obwalden 152; organisational interdependence 282; organisation of 70 ; political equality and 281; power relations and 35 ; property rights of 38 ; resilience of in Switzerland 53-54, 290-295; resistance to the implementation of public policies 39-40; robustness of 290; Sarnen 147; and the state 35, 37, 40-41, 288-290; strategic study on 264; subsidies; sustainability of 279; Swiss 294-299; symbolic bond between members 295-296; transformational change in 9-10; transformation in the nineteenth century 22; transformation into villagebased organisations 10; and translation of public policies $37-38$

commoner spirit $268,271 \mathrm{n} 31$

common forest management, changes in 208-215

common-pool resources (CPRs) ix, 1, 4-5; analysis of 37; commoners' organisations and 38; development pathways and 54; economic value of 292; and management of 47, 53-54; and non-commoners share of 291; peasant societies and 45; relative prices of 277; rights to 152

common property: long-term continuity of 279-282; rights 2; theoretical commons literature about 282-285

common property institutions, collective actions and 47-48 
common property management, women's work and 56

commons: debates on management of 1 , 79-80, 202; vs. privatisation 76-77; privatisation of $76-77$

commons organisations, new roles of 22-24 commons regions, comparative analysis of 277

commons research: institutional economics and 47-52; shortcomings in 35

commons trap 35

communal dualism xi, xiii, 199, 239, 240; see also municipal dualism

communalisation, and feudalism 70 , 110-111, 239, 253, 271n5

communal tenure ix

communal work (Gemeinwerk) 166; of the bourgeoises 205

communication 19

community poor welfare 21

community self-administration 20

Confederate cantons 265

conflict-solving mechanism 19

conservation 169, 172, 177, 201, 202, 208, 218, 229, 235, 249-251, 256, 259

consortages 8, 10, 192-194, 196-197, 214, 218-220, 224-225

consorts or allodiateurs 192

Consultative Commission 250

consumption society 25-30, 280-281; financial situation and 285; protection in 127

corporate structures, multi-layered structure of $265,267,268$

corporation: financial situation and 99-101; separation of $80-81$

corporation citizen 240; communal work (Gemeinwerk) 166

Corporation of Citizens (Bürgergemeinde) 17-18, 22, 23, 108, 163; financial status of 99; transformation of 109

Corporation of Uri, adjustment vs. resistance to change 91-94

corporations: agreement among the 247; benefit from the resources of the 19; Canton of Ticino 261-262; decline of the old 264-268; local bargaining power of 56; in Switzerland 18

corporations' constitutional laws (Einung) 162-167

cow herds 246

Crans-Montana, water exchange agreement 38-39 cross-regional political organisation 70-71

cross-subsidising resource management 286

cultural landscape 45; ecosystem, maintaining 279, 291

dangerous goods, transportation of 213-214

decentralised village units 267

deforestation 26, 28, 256, 260

Dent blanche 189

design principles, Ostrom's 19, 35, 47, 277, 279, 282, 290

discourse xi, 6, 29, 30, 36, 49, 52, 109, 289, 290, 296

distribution of Assets (1875) 118, 125, 132

Dorfschaften (village communities, village corporations) 10, 71, 265-267

Dötra area/plateau 249-250

drudgery function, increasing curve for 46

dual municipal organisation 22; see also communal dualism; municipal dualism

Early Modern Period: 21-22, 279-280; Chur 111-121; Korporation Uri 68; Land Uri 74-78; Swiss Confederation cantons and 238-239

Ecology, age of 8, 280

economic and institutional change, research and 7

economic anthropology 48-49

Economic Enlightenment 21, 122-123

economic resilience, of commoners' organisations 291

Eidgenossenschaft 68

Eidgenössische Tagsatzung (Swiss Meeting of Representatives) 21

emotional 'utility,' in commoners' organisations 291

energy: sources of 28 ; use of 24

engine-driven machines 27

Ensminger, Jean 8; Ensminger-Haller framework 50; institutional change and 52, 147, 157; model of 49, 292, 293

European railway network 27

farming communities, economic behaviour of 46

farms, evolution of the number of $\mathbf{2 4 1}$

Federal Act on Homelessness (1850) 192, 198

Federal Civil Code 36

Federal Constitution (1874) 22

federal forest law/policy 28, 208 
Federal Law on Forests (1991) 30

feudal actors (nobility and monasteries) 69

feudalism 25, 70; and communalisation $70-71$

floods 25, 28, 40, 131; protecting land from $20,38,77,87,174$

Fondue 120, 121

foreigners 76, 120, 152, 262

forest consortium: Anniviers' 211-212; public and private revenue of Anniviers' 210

forest cover 256-260

Forest Day 129

forest economy, transformation of the 121-130, 208

forest management: in Canton of Ticino 234, 252-260; changes in 208-215; pasturing activities and 40; service-based approach 213

forest pasture separation 155

forest path construction 155

Forest Policing Ordinance (1846) 124

forest reserves 30, 247, 259

forestry consortium 181, 208

forests 47, 73; changing roles of 252-256; utilisation right for 77

forests and pastures, collective management of 238

forest statute of Chur 121

forest subventions 211-213, 254-256

forest transition process 256, 259-260

French Revolution, principle of equality of citizens 198

French-speaking area 8

Future of the Commons, The 36

game theory 4

Gemeindedualismus (municipal dualism) 105

gender issues 7, 9, 24, 56, 92-93, 124, 162, 196, 206-208, 263, 272

Genossamen 71

Giacometti, Enrico 108

global commons 1

global economy 285-288

Global South, lessons from 297

'glocal' economy 285-288

Gotthard 65, 78, 82

governance structures 19

Governing the Commons (Ostrom) 2, 18-19, 47, 291

grazing rights, disputes over 246-247

Great Britain 27

Grimentz 199, 201, 207, 221; coat of arms of families in the bourgeoisie hall of 204; homes in 192
Grimentz-Zinal ski-lift company 222

groups, exclusion or inclusion of 19 ,

$$
\text { 114-121 }
$$

Guilds Constitution 9

guilds regime 111-113

Habsburgs' emphasis 20

Habsburg's sovereignty 70

Halbjahreskilchgang, in Sarnen 281

Hardin, Garrett 1, 4; The Tragedy of the Commons 48

Heimatrecht (citizenship) 21

Helvetic Republic 68, 78-79, 198

Helvetic Revolution 22, 114

herders, complaints of 290

herdsmen and alpine bailiffs, swearing in of 95

heritage conservation work, of the bourgeoisies 202

heritage preservation 209

Hintersassen (socmen/underprivileged residents) 9, 21, 112, 152, 279, 281

historical bourgeoisies 205

homelessness, abolition of 157

hydroelectric basin projects: in the Greina area 251; in Lukmanier area 251; in the Luzzone valley 251

identity: importance of 200-201; proof of 201-205

identity utility $8,12,55,268,277,292$

ideology 8, 10, 147, 157, 176-180, 183, 184, 292

industrial society 25, 139, 280; financial yield and 280; modernisation pressure on 26; municipal financial resource in 123-128; pressure of modernisation in 8 ; timber production and 28 ; transformation from 'agrarian society' to 27 ; transformation into consumption society $28-29$

Institutional Analysis and Development (IAD) framework 5, 48

institutional change, Ensminger's model of 147

institutional designs and strategies 180-181

institutional economics: and commons studies 47-52; commons studies and 47-52; and public policy analysis 37

Institutional Resource Regime (IRR) framework 37

Institution building processes (constitutionality) 55-56, 279, 297-298 institutions, conditions for creating new 55 
internal coherence 37

internal corporation structures, bargaining power with 174-176

International Association for the Study of the Commons (IASC) 1

International Carriage of Dangerous Goods by Road (ADR) 213-214

International Certificate of Sustainable Forestry (FSC Label) 129

Italian Bailiwicks 265

Kloster Wettingen 70

Korporationsgemeinde (corporation municipality) 17

Korporationsgemeinde (assembly) 67, 79, 85-87, 90-94

Korporation Uri (Corporation of Uri) 7, 9, 63, 64, 66, 101n6, 282, 288, 290; aerial photo of 65 ; canton's political structure of 82-95; economic dynamics of 97-98; facts and figures on 65-68; formation and development of 78-82; history of 69; landed property of 64 , 66; management of 96-98; quantitative facts on 65-68; research on 68; unteres Reusstal or Urner Talboden 65

Korporation Ursern (Corporation of Ursern) $63,69,71,74,79,81,92$

Kulturkloster, the 99, 100

labour, division of 19

Landamman 70, 71, 80

Landesausbau (land development) 25

Land Glarus (country of Glarus) 70

Landleute von Uri (citizens of the Land Uri) 9,70

land management, new forms of 248-249

Landolt, Elias 55, 82

Landrat 71, 74, 87

landscape and biodiversity conservation 137-138, 235, 249, 250, 255, 259, 280

Land Schwyz (country of Schwyz) 70

Landsgemeinde (assembly of entitled citizens) 71, 75, 114; of Uri 281-282

Land Uri (COUNTRY OF Uri) 69, 71, 72; agricultural change and 73 ; as an autonomous political actor 69; crossvillage regulation of resources and 71 ; political system of 74-78

land use: changes in 216; transformation of 130-138

land utilisation, Thünen's model of 108

Late Middle Ages xi, 2, 6, 8, 9, 19-21, 23, 72, 74, 105, 108-111, 121, 279, 281-283
Law on Communal Regime (1851) 198

Law on Education (1849) 198

Leventina region 265, 284

literature review 148

livestock, evolution of number of owners and $\mathbf{2 4 2}$

local common-pool resource institutions $1-2$

local conditions 19

local solar energy 25

long-enduring institutions $\mathbf{4 8}$

longue durée perspective 18, 30, 69, 108

Lucomagno alp 247

Lukmanier area 236, 243-245, 249

Magadino, Plain of 234

manorialism 20

Maran Dairy Team 136

Marchenstreite 71

mass consumption 25

mass motorisation 25

material standard of living, rise in 28

means of control 17

Mediation period 22

Meiers (stewards) 70

Merzario, Raul 235

methodological individualism 4

Miaskowski 18

Middle Ages: collective administration of resources in 69-70; economic structures and dynamics 72-73; expansion of control 10

migration: citizenship by $119-120$; and commoners' economy 262, 279; transhumant 131, 133-138, 197

mire landscape (Moorlandschaft) 185n2

Mittelland 25, 26, 29

modernisation 81-82

monastery of Disentis 71

monastery of Engelberg 71

moral economy approaches 35

mountain pasture management, shift in 244

multi-layered community 10; structure 265, 267, 268

municipal dualism 22, 105, 108, 114-118, 199, 262, 263; Switzerland and 17

municipal financial resource, industrial society and 123-128

municipal land-use planning policy 39

Nachbarschaftsverbände (neighbourhood associations) 71,110

narrative $4-6,49,50,52,53,55,148,162$, 176-180, 289, 294 
National Park (Parc Adula) project 268

naturalisations 262

natural resource management 40

natural resources: changing 95-96; public policies and 36-37; sustainable management of 37

nature conservation, effect of on pastoral use 251

Netting, Robert, Balancing on an Alp ix, 2, 235; and Elinor Ostrom's interconnectivity 2 ; management of pastoral commons and 47

New Institutionalism 6, 8, 37, 47; political geography, economics and ecology and 52-53

Niedergelassene 114-118, 281

Obwalden 147; spatial characteristics of 148-151

Obwalden Farmers' Association 154

Olivone, Canton Ticino 238-241, 260, $262,264,268-269$

organisation, cross-regional political 70-71

Orts(bürger)gemeinde 17

Ostrom, Elinor 1, 35, 47, 235; analysis of her work 4-6; commoners' organisations and 35; design principles of 19,35 , 139, 277, 279, 282, 290; eighth design principle of 36; Governing the Commons ix, 2, 18, 47, 291

Otto I (emperor) 110

overseas migration 262

participation 19, 20, 115, 116, 139, 140, 148, 196, 198, 200, 205-207, 228, 261, 267

pastures 25-26, 47; changes in 29; as economic structures 72-73, 94-95; evolution of use of Val d'Annivers 217; long-term economy of 24-30; modernisation pressure on $26-28$; productivity of 25 ; uses of 40 ; utilisation right for 77-78

patriciate 18, 22, 260-261; see also corporations; urban 22

patriziato (corporation) 7-11, 17, 55, 234-271; see also patriciate

Patriziato generale of Olivone, Campo and Largario (PG-OCL): 10, 234-274, 237,

266; landed property of 235,236

peasant economics 46-47; Chayanov's model of 47,55

peasant societies 46 peasant studies 46-47

PG-OCL 265; see also Patriziato generale of Olivone, Campo and Largario (PG-OCL)

political ecology 6

political equality 281

political participation, equal rights of inhabitants to 198

political rights $22,81,261$

Politische Gemeinde (municipality of residents) 9, 17, 105, 108, 109, 236-240, 256, 261, 264

poor welfare, community $21-22$

prémices $225,230 \mathrm{n} 2$

private property $4,18,21,26,49,51-54$, 73, 76, 131, 234, 238, 280

Pro Natura environmental association 250 property rights $36-37$; types of 193-194 public law 17, 18, 81, 83, 92, 102, 105, 151 public policies, commoners' organisations translation of $37-38$

quarries $101 \mathrm{n} 7$

rational choice approaches 4, 35

Regeneration 22

Regional Tourism Organisation 250

residual common ownership, of land 219-226

resilience $7,8,10,45,50,52-56,180,181$, 183, 226, 264, 290-294

resource regime 37,50

resources: codifying the uses of 36 ; collective utilisation of 18

Restoration period 22

restrictive citizenship 79

Riemenstaldental 71; conflict over 73

right to grant 17

Rural Commons 107

Russia, land use by farmers in 46

Saint-Luc 199-200, 219

sanctions, appropriateness of 19

Sarnen 8; common characteristics of 157; commoners' organisations (Canton Obwalden) 147; and consolidation of the federal state 153-156; formation and development of 151-153; ideology 176-180; key data on 158-159;

landed property of 150 ; organisation of 157-162; Sarnen corporations 10, 151; structural diversity of 157 ; study area of 149; transformation of $156,182-185$ 
SCALES (Sustainable Commons

Adaptations to Landscape Ecosystems in Switzerland) 1, 3, 6, 84, 89, 109

Schläppi, Daniel 22

Schmähsonntag (reviled Sunday)

112-114, 281

Schweighöfe (farms) 70

Schweizer Allmend in ihrer geschichtlichen Entwicklung (von Miaskowski) 18

Schweizerischer Alpwirtschaftlicher Verein 85, 154, 156, 280

Schweizerischer Forstverein 280

Second World War 216, 221, 242, 245, 247,253

secular common dyke associations 38

seigniory 192

self-administration rights (colonists' rights) 20-21

self-organised behaviour 40

self-subsistence, change from to export economy 73

Shanin, T. 46

sheep alp 236

SNEE contract/negotiations $87,88,101 \mathrm{n} 6$ social anthropology 6, 7, 8, 47, 52, 109;

farming communities and 46

social bonds 225

solar energy 25, 121

Staatsarchiv des Kantons Graubünden 109

state, the: intervention of 8 ; shadow of 40-41

Statutes of the City of Chur 130

subsidies 2, 10, 28, 101, 128, 154, 194, 211, 213-215, 256, 286, 289, 298

subsistence-oriented farming communities 46 summering rights 152, 156, 235-236, 279

supra-regional economic interdependencies 279

sustainable development goals (SDGs) 1,298

Swiss agricultural system, and the global market 289

Swiss Association of Corporations of Citizens (SVBK) 18, 23, 24

Swiss citizenship 22, 199, 261

Swiss Civil Code 2, 192

Swiss commoners' organisations 12 ; history of 5 ; robustness of $2-3$

Swiss commons lab 2, 8; and constitutionality 55-56

Swiss commons landscape: diversity of 17; institutional development of 19-24; phases of 8

Swiss Confederation 68
Swiss Federal Constitution, citizenship rights and 22, 261

Swiss Federal Forestry Police Act (1876) 28

Swiss Federal State 22, 285

Swiss language regions, case studies on 8

Swiss resident citizens, equal rights for 22

Swiss Rural History Society

(Schweizerische Gesellschaft für ländliche Geschichte) 7

Swiss summering areas, ownerships of 24

Swiss woodlands, ownerships of 24-25

Switzerland 279; historiography on central 69; invasion by the French 22; Italianspeaking $8,234,238-239,283,284$; as a laboratory for commoners' organisations 294-299

Talschaften (valley communities) 19, 71 technological innovations 27

Thünen's model of land utilisation 108

Ticino Patrician Alliance (ALPA) 263-264

timber production, industrial society and 28

tolerated people, naturalisation of 157

Törbel (Swiss Canton of Valais) ix tourism 50, 138, 191, 200, 225, 228, 229, 249, 251, 281, 287-289; effect of on pastoral use 251

traditional agricultural calendar 242-243

traditional products 45

traditional semi-annual reunion 148

Tragedy of the Commons, The (Hardin) ix, 48 transformation processes 10

transhumance, cross-border system of 9 , 131-134, 197

Transport Statutes of the Guild of the Smiths 111

universal suffrage, in Switzerland 117, 206, 272 n 36

urban patriciate, political decision-making and 22

Urner Volksblatt 80

Ursern see Korporation Ursern (Corporation of Ursern)

utilisation regulations 19; limited rights 22

Valais community 18; cantonal forest association of 213-215

Val d'Anniviers (Canton Valais) 10, 282, 288, 295; bourgeoisies communal work in 205; bourgeoisies to municipalities 198200; commoners' organisations in 192; equal rights of inhabitants to political 


\section{Index}

participation 198; evolution of pasture load in 217; geographical and current socio-economic conditions of 189-194; history of 194-197; landed property of 191; merging of municipalities of 200201 ; municipality of 190 ; population of 190; socio-economic challenges in 192 Valle di Blenio 282

Valle di Campo 236, 246

Vicinati see Dorfschaften

village aristocracy, political decision-making nd 22

village chapels 265, 266

village community, collective rights of the 73 von Miaskowski, August, Die Schweizer

Allmend in ihrer geschichtlichen

Entwicklung 18

von Rapperswil family 70

Vorgesetzte Herren 71 wage labour 286

water management 38

water rights xi, 39, 87, 136, 251

Wendler, Uwe 111

western liberal democracies 40

winter sport resort 249

women see gender issues

women's suffrage $24,91-93,272$ n36

woodlands $26-27,28,95$; as economic structures 72-73, 94-95; exploiting 73-74; long-term economy of 24-30; transformation to a 'consumption society' and 29-30

wood processing Post Square, Chur 127 World War Two see Second World War

Zelgensystem (tillable land system) 25 Zurich Abtei Fraumünster (Abbey of Fraumünster) 70 